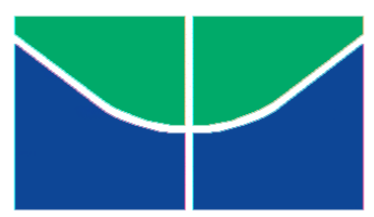

UNIVERSIDADE DE BRASÍLIA - UnB

FACULDADE DE EDUCAÇÃO - FE PROGRAMA DE PÓS-GRADUAÇÃO EM EDUCAÇÃO - PPGE

SHIRLEY MARGARETH BUFFON DA SILVA

A MORAL EM QUESTÕES SOCIOCIENTÍFICAS NO ENSINO DE BIOLOGIA 





\title{
A MORAL EM QUESTÕES SOCIOCIENTÍFICAS NO ENSINO DE BIOLOGIA
}

\begin{abstract}
Tese apresentada ao Programa de PósGraduação da Faculdade de Educação da Universidade de Brasîlia, na área de Educação em Ciências e Matemática, como requisito parcial para a obtenção do grau de Doutor em Educação.
\end{abstract}

Orientador: Prof. Wildson Luiz Pereira dos Santos 


\section{FICHA CATALOGRÁFICA}

Ficha catalográfica elaborada automaticamente, com os dados fornecidos pelo(a) autor(a)

\section{Silva, Shirley Margareth Buffon da \\ A moral em questões sociocientíficas no ensino de}

$\mathrm{m}$ Biologia / Shirley Margareth Buffon da Silva;

orientador Wildson Luiz Pereira dos Santos. -Brasília, 2016. $267 \mathrm{p}$.

Tese (Doutorado - Doutorado em Educação) -Universidade de Brasília, 2016.

1. Questões sociocientíficas. 2. Moral. 3. Ética. 4. Ensino de Biologia. 5. Biotecnologia. I. Santos, Wildson Luiz Pereira dos, orient. II. Título. 


\section{SHIRLEY MARGARETH BUFFON DA SILVA}

\section{A MORAL EM QUESTÕES SOCIOCIENTÍFICAS NO ENSINO DE BIOLOGIA}

Tese apresentada como requisito parcial para obtenção do grau de doutor em Educação na área de Ciências e Matemática, do Programa de Pós-Graduação da Faculdade de Educação da Universidade de Brasilia.

\section{BANCA EXAMINADORA}

Prof. Dr. Wildson Luiz Pereira dos Santos (Orientador) - UnB

Prof. Dr. Pedro Guilherme Rocha dos Reis (Examinador externo) - Universidade de Lisboa

Prof. Dr. Natan Monsores de Sá (Examinador externo) - FS-UnB

Profa. Dra. Albertina Mitjáns Martínez

(Examinador interno) - FE-UnB

Profa. Dra. Cláudia Márcia Lyra Pato

(Examinador interno) - FE-UnB

Prof. Dr. Cleyton Hércules Gontijo

(Suplente) - FE-UnB

Brasilia, 13 de junho de 2016. 

A todos que renunciaram em favor das minhas ilusões. 



\section{AGRADECIMENTOS}

Ao Prof. Dr. Wildson Luiz Pereira dos Santos por ter me iniciado no caminho da pesquisa e do letramento científico, no início do $1^{\circ}$ ano do ensino médio há 28 anos no CED 02 do Gama. Um jovem professor de Química que colocava uma frase provocativa no quadro no início de cada aula e nos pedia para fazer uma reflexão sobre ela. Nos ensinava sobre o método científico e dizia em um texto que "o cientista virou um mito e que todo mito é perigoso". Fazia-nos cientistas em suas aulas práticas de laboratório e nas visitas guiadas pelos laboratórios de Química da UnB e do Laboratório Central de Saúde Pública do DF. Depois de iniciado o caminho coube a ele a condução de mais uma etapa desse aprendizado. Ao professor Wildson minha gratidão por ter me apresentado e conduzido nos caminhos da ciência. A semente caiu em solo fértil e germinou!

Ao prof. Dr Natan Monsores de Sá colega que conheci na Faculdade JK e que tanto admiro. Tão jovem, e com tanto conhecimento acumulado!

Ao professor Dr. Pedro Guilherme Rocha dos Reis pelas contribuições no exame de qualificação, por ter gentilmente aceito participar da banca de defesa, além da oportunidade de estreitamento dos laços entre Brasil e Portugal.

À professora Dra. Albertina Mitjáns Martínez pelo aprendizado na disciplina de subjetividade e por ter me encaminhado na compreensão da dimensão psicológica da moral.

À professora Dra. Maria Abadia da Silva pela oportunidade de crescimento e aperfeiçoamento no programa de pós-graduação da Faculdade de Educação e participação com um capítulo do livro da coleção de políticas públicas. Obrigada por ter acreditado em mim!

À professora Dra. Cláudia Márcia Lyra Pato por ter aceito participar da banca de defesa deste trabalho.

À professora Dra. Ângela Branco pela ajuda na elaboração dos instrumentos de coleta de dados.

À Karol e Marcos amigos de caminhada e partilha por terem estado presente em todos os momentos. Juntos compartilharemos essa vitória!

Ao amigo Marcelo pela ajuda tão bem-vinda em todos os momentos. As palavras não conseguem exprimir minha gratidão! 
À Natália que quando eu estava saindo da escola abatida, por não ter conseguido realizar a oficina e não ter encontrado nenhum professor de Biologia que participasse desta pesquisa, apareceu no corredor da escola e me apresentou ao professor Marco Antônio. Uma luz na escuridão!

Ao professor Marco Antônio que gentilmente me cedeu as aulas para a realização deste estudo. Ao amigo Marco Antônio minha imensa gratidão!

À Roseline Strieder pela amizade, pelo aprendizado proporcionado no projeto Obeduc/Capes e pela ajuda fundamental em vários momentos.

À Yandra pela ajuda na montagem dos vídeos e nas transcrições.

Ao tio Vitor Menna Barreto pela tradução do abstract deste e de outros trabalhos.

À Emília Bottini pela leitura e sugestões.

Aos professores e colegas do programa de pós-graduação da Faculdade de Educação pelo tempo de convivência e discussões enriquecedoras.

À Direção da escola pela recepção, confiança e apoio em todas as horas.

Aos estudantes que por meio de sua participação permitiram a realização deste trabalho. Lembranças de um tempo muito especial!

Ao professor Dr. Sidnei Quezada pelo envio dos artigos tão necessários para a realização da revisão de literatura apresentada no capítulo 1 desta tese.

À Dália Conrado pelos precisos esclarecimentos nos momentos de dúvida e envio de referências importantes para o desenvolvimento deste trabalho.

À Marinalva amiga de todas as horas pela ajuda na correção deste trabalho.

Aos meus bisavós Giácomo Simonelli e Catterina Pesenti, Antônio Buffon e Augusta Favallessa que em 1891 a bordo do navio Birmânia, tiveram a coragem abandonar sua terra natal Itália e de recomeçarem suas vidas com seus filhos em um terra tão distante e tão cheia de desafios a serem vencidos. Obrigada pelo exemplo de força e coragem!

Aos meus pais, especialmente minha mãe Regina Buffon que quando pequena me apresentava os professores catedráticos com tanto respeito que passei a sonhar que um dia poderia ser como eles. Obrigada mãe por nutrir meus sonhos!

Ao meu esposo Rodrigo por ter renunciado em muitos momentos em favor dos meus sonhos. 
Aos meus filhos Pedro e Isabel que representam o futuro e me dão força para enfrentar as dificuldades do caminho sem desistir.

Às muitas e muitas pessoas que têm feito/fizeram parte de minha caminhada pessoal e profissional e que têm me ensinado que o indivíduo se constrói nas interações.

À Secretaria de Estado de Educação do Distrito Federal pela liberação para a realização deste trabalho.

À Capes pelo apoio a realização desta pesquisa.

A Deus, mestre supremo, que tem orientado meus caminhos. 

Por que existe o mal no mundo? Escuta com atenção: uma mãe está bordando. Seu filho sentado em um banquinho contempla seu trabalho pelo avesso. Vê os nós do bordado, os fios emaranhados. E diz: "mamãe o que você está fazendo? O seu trabalho não está claro”! Então, a mãe abaixa o bastidor e mostra-lhe a parte boa do bordado. Cada cor está no seu lugar e a variedade de fios se ajusta a harmonia do desenho. É isso! Nós vemos o avesso do bordado; estamos sentados em um banquinho baixo. São Pio de Pietrelcina 



\section{RESUMO}

Esta tese é o resultado de uma investigação realizada com estudantes no $2^{\circ}$ ano do ensino médio em uma escola pública do Distrito Federal. O objetivo foi desenvolver sequências didáticas com a introdução de questões sociocientíficas (QSC) relativas a dilemas da biotecnologia que envolvem aspectos morais, visando caracterizar implicações pedagógicas para tratar questões morais no ensino de Biologia. Para isso, foram identificados aspectos morais adotados pelos estudantes relativos às QSC, antes, durante e depois da discussão dos dilemas, com o propósito de encontrar possíveis indicadores da relação entre abordagem de QSC e aspectos morais. A investigação tomou como referência pesquisas empíricas e estudos sobre inserção curricular de QSC e moral, bem como estudos no campo da psicologia e da filosofia. As sequências didáticas desenvolvidas foram sobre os seguintes dilemas morais: alimentos transgênicos, clonagem e terapia gênica. As teorias morais normativas e a metaética foram o referencial teórico utilizado na análise dos dados. No caso dos princípios morais nos embasamos na Declaração Universal de Bioética e dos Direitos Humanos e Valores do Espírito do Desporto. Foi realizada uma abordagem investigativa de cunho qualitativo utilizando-se a análise textual discursiva para identificar categorias emergentes nos discursos dos atores, obtidos por meio de questionários, entrevistas e após o desenvolvimento de uma sequência didática com discussões de QSC. Os dados construídos apontaram que a maioria dos estudantes interpreta QSC sobre temas da biotecnologia com base nas teorias morais deontológica e utilitarista e também no ceticismo moral. Nas QSC sobre alimentos transgênicos a moral utilitarista foi a mais utilizada. Já no caso da clonagem e da terapia gênica a moral deontológica foi predominante, com um pequeno número de estudantes que apresentaram ceticismo moral. Nesse contexto, percebeu-se que as aplicações da biotecnologia abordadas foram analisadas de formas diferentes em termos de moralidade por parte dos estudantes, e que fatores como o contexto das questões, emoções, existência de valores protegidos e sagrados podem ter influenciado o julgamento moral. Além disso, concluímos que com a realização da sequência didática houve mudanças nas percepções dos estudantes quanto a algumas categorias utilizadas na análise como, uso de alimentos transgênicos, consciência ecológica e percepção de risco. Os dados demonstraram também que não houve uma mobilização significativa dos estudantes nas discussões das QSC. A análise do desenvolvimento das sequências didáticas aponta dificuldades para se incluir aspectos morais em discussões de QSC, tais como a inserção de atividades didáticas apropriadas para desenvolver a participação dos estudantes e o contexto curricular da escola. Defendeu-se como tese que a introdução de aspectos morais em QSC é essencial no ensino de Biologia para preparar os estudantes na tomada de decisão moral. Para que isso ocorra no contexto curricular da maioria das escolas brasileiras, muitos desafios precisam ser enfrentados, por exemplo, a formação de professores e o desenvolvimento de estratégias de ensino variadas dentro da diversidade de questões existentes. Conclui-se que tal investigação identificou elementos para o entendimento de como discussões de QSC no ensino de Biologia podem contribuir para o favorecimento do raciocínio moral dos estudantes.

Palavras-chave: Ensino de Biologia. Questões sociocientíficas. Moral. Ética. Biotecnologia. 



\begin{abstract}
This thesis is the result of an investigation carried out with students in the 2nd year of high school in a public school in the Federal District. The goal was to develop didactic sequences with the introduction of socio-scientific issues (SSI) concerning biotechnology dilemmas involving moral aspects, aiming to characterize pedagogical implications to address moral issues in Biology teaching. To achieve this goal, moral aspects adopted by students regarding SSI were identified, before, during and after the discussion of the dilemmas in order to find out possible indicators of the relationship between SSI approach and moral issues. The investigation used, as reference, empirical researches and studies on curricular inclusion of SSI and moral, as well as studies on moral in the fields of psychology and philosophy. The developed didactic sequences involved the following moral dilemmas regarding biotechnology SSI: GM food, cloning and gene therapy. The normative moral theories and meta-ethics were the theoretical framework used in the data analysis. In the case of moral principles, we relied on the principles of the Universal Declaration of Bioethics and of Human Rights, and in the case of genetic doping, on the Values of Sport Spirit. An investigative approach of qualitative nature, using discursive textual analysis, was performed to identify emerging categories in the speeches of the actors, obtained through questionnaires, interviews and after the development of a didactic sequence with SSI discussions. The obtained data showed that most students interpret SSI on biotechnology having as a basis moral deontological, utilitarian theories and moral skepticism. In SSI on GM food utilitarian moral was the most used. In the case of cloning and genetic therapy, deontological moral was predominant. A small number of students showed moral skepticism. In this context, we realize that the discussed applications of biotechnology were analyzed in different ways, in terms of morality, by part of the students, and that factors such as the context, emotions, existence of protected and sacred values may have influenced their moral judgment. Furthermore, we noticed that, with the completion of the didactic sequence, there were changes in the perceptions of the students regarding some categories used in the analysis, such as the use of GM food, ecological awareness and risk perception. The data also show that there was not a significant mobilization of the students in the SSI discussions. The analysis of the development of the didactic sequences points out several difficulties to introduce moral aspects in SSI discussions, such as appropriate didactic activities to develop the participation of the students in SSI and the curricular context of the school. We defend the thesis that the introduction of moral aspects of SSI is essential in Biology teaching to prepare students for in their moral decision-making. To attain this goal, in the curricular context of most Brazilian schools, many challenges need to be faced, such as teachers' proficiency and the development of various teaching strategies within the diversity of the actual scenarios. In summary, this research identified elements for understanding how SSI discussions in Biology teaching may contribute to foster the moral reasoning of the students.
\end{abstract}

Keywords: Biology teaching. Socioscientific Issues. Moral. Ethics. Biotechnology. 



\section{LISTA DE ILUSTRAÇÕES}

\section{Lista de figuras}

Figura 1 Elementos sociocientíficos da alfabetização científica funcional. 49

Figura 2 Indicadores de progressão do pensamento ético.

Figura 3 Eixos de atuação da professora pesquisadora na sequência didática.

Figura 4 Organização da sala de aula para as sessões de discussão e posicionamento das câmeras para filmagem.

Figura 5 Sequência de análise textual discursiva dos discursos dos estudantes.

Figura 6 Tempo de fala do professor e dos estudantes.

\section{Lista de gráficos}

Gráfico 1 Distribuição da frequência de estudantes em relação ao uso de alimentos transgênicos.

Gráfico 2 Distribuição da frequência de estudantes quanto às percepções de contribuição e risco por instrumento.

Gráfico 3 Distribuição da frequência de estudantes em relação a percepção de riscos e benefícios dos alimentos transgênicos

Gráfico 4 Distribuição da frequência de estudantes em relação aos benefícios dos alimentos transgênicos.

Gráfico 5 Distribuição da frequência de categorias relacionadas a percepção dos estudantes em relação aos riscos dos alimentos transgênicos.

Gráfico 6 Distribuição da frequência de categorias relacionadas à dimensão temporal dos riscos dos alimentos transgênicos.

Gráfico 7 Distribuição da frequência das categorias soube ou não definir o que são transgênicos antes da sequência didática.

Gráfico 8 Distribuição da frequência relacionada às categorias de incorporação do conhecimento científico dos estudantes em relação ao milho e salmão transgênicos

Gráfico 9 Distribuição da frequência das categorias de consciência ecológica dos estudantes por instrumento analisado....

Gráfico 10 Distribuição da frequência de considerações do domínio moral, não moral e em branco dos estudantes segundo os instrumentos utilizados. 
Gráfico 11 Distribuição da frequência de moral deontológica, utilitarista e ceticismo moral dos estudantes por instrumento utilizado.

Gráfico 12 Painel de gráficos relacionados a distribuição da frequência dos princípios morais dos estudantes por instrumento analisado

Gráfico 13 Painel de gráficos em relação a distribuição da frequência dos princípios morais dos estudantes por instrumento analisado

Gráfico 14 Distribuição da frequência de estudantes que apresentaram conhecimento prévio sobre clonagem.

Gráfico 15 Distribuição da frequência de estudantes contrários ou favoráveis a clonagem.

Gráfico 16 Distribuição da frequência de discursos do domínio moral e não moral, argumentos insuficientes e em branco/não opinou por instrumento.

Gráfico 17 Distribuição da frequência de estudantes por categoria de julgamento moral, deontológica, utilitarista, ceticismo moral e argumentos insuficientes.

Gráfico 18 Distribuição da frequência de princípios morais apresentados pelos estudantes

Gráfico 19 Distribuição da frequência de estudantes com conhecimento prévio sobre terapia gênica.

Gráfico 20 Distribuição da frequência de estudantes contrários, favoráveis e argumentos insuficientes sobre a terapia gênica.

Gráfico 21 Distribuição da frequência dos estudantes contrários, favoráveis e em branco/não opinou sobre terapia gênica por instrumento.

Gráfico 22 Distribuição da frequência de estudantes que apresentaram considerações relativas ao domínio moral, não moral, em branco/não opinaram e 203 argumentos insuficientes.

Gráfico 23 Frequência de estudantes que responderam as questões com base nas teorias morais deontológica, utilitarista, ceticismo moral e argumento insuficiente.. 205

Gráfico 24 Distribuição da frequência de princípios morais utilizados pelos estudantes ao responder aos instrumentos do estudo.

\section{Lista de quadros}

Quadro 1 Periódicos publicados no Brasil e no exterior, selecionados para estudo e sua classificação no sistema Qualis 2014 nas áreas de ensino e educação em Ciências.

Quadro 2 Artigos empíricos sobre moral em artigos de QSC. 
Quadro 3 Referenciais teóricos dos artigos empíricos sobre moralidade por autor.............. 63

Quadro 4 Classificação das pesquisas segundo o tema de estudo...................................... 65

Quadro 5 Valores usados na tomada de decisão sobre conservação biológica.................... 71

Quadro 6 Relação das citações extraídas das DCNEM e as respectivas categorias de análise.

Quadro 7 Relação das citações extraídas da BNCC versão preliminar e as respectivas categorias de análise

Quadro 8 Atmosfera moral em aulas de Ciências........................................................... 113

Quadro 9 Conteúdo programático da sequência didática utilizada na coleta de dados........ 125

Quadro 10 Cronograma de atividades das turmas 2C e 2D com aulas na segunda-feira....... 130

Quadro 11 Cronograma de atividades das turmas 2A, 2B e 2E com aulas na quarta-feira..... 132

Quadro 12 Resultados do teste binomial para os pares de variáveis em questão.................. 163

Quadro 13 Resultados do teste de McNemar para os pares de variáveis em questão.............. 163

Quadro 14 Exemplos de discursos dos estudantes com relação as categorias emergentes relacionadas a incorporação do conhecimento científico após a realização da sequência didática sobre transgênicos ........................................................... 17

Quadro 15 P-valores dos testes realizados.................................................................. 174

Quadro 16 P-valores dos testes realizados............................................................... 211 



\section{LISTA DE TABELAS}

Tabela 1 Frequência e percentual de ocorrência dos artigos de QSC teóricos e empíricos que tratam da moral.

Tabela 2 Frequência e percentual de artigos de QSC empíricos sobre aspectos morais por tema de estudo.

Tabela 3 Frequência de estudantes matriculados por turma.......................................... 124

Tabela 4 Categorias da análise dos discursos do professor e dos estudantes.................... 214 



\section{LISTA DE ABREVIATURAS E SIGLAS}

CTS Ciência-Tecnologia-Sociedade

QSC Questões Sociocientíficas

ASC Aspectos Sociocientíficos

LDB Lei de Diretrizes e Bases 9.394/96

PCNEM Parâmetros Curriculares Nacionais para o Ensino Médio

PCN+ Orientações Complementares aos Parâmetros Curriculares Nacionais

OCNEM Orientações Curriculares para o Ensino Médio

MEC Ministério da Educação e Cultura

DCNEM Diretrizes Curriculares Nacionais para o Ensino Médio

BNCC Base Nacional Comum Curricular

CAPES Coordenação de Aperfeiçoamento de Pessoal do Nível Superior

SSI Socio-scientific Issues

STS Science-Tecnology-Society

EJA Educação de Jovens e Adultos

EM Ensino Médio

SD Sequência didática

PDTC Pesquisa e Desenvolvimento Tecno-científicos

TCLE Termo de Consentimento Livre e Esclarecido

CAPES Coordenação de Aperfeiçoamento de Pessoal de Nível Superior

IBOPE Instituto Brasileiro de Opinião Pública e Estatística

SEEDF Secretaria de Estado de Educação do Distrito Federal

RA Região Administrativa

OBEDUC Programa Observatório da Educação

PD Componente Curricular Parte Diversificada 



\section{SUMÁRIO}

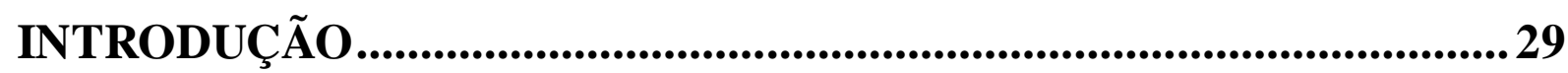

1 QUESTÕES SOCIOCIENTÍFICAS NO ENSINO DE CIÊNCIAS.......39

1.1 Letramento científico: origem e significado ...................................................... 40

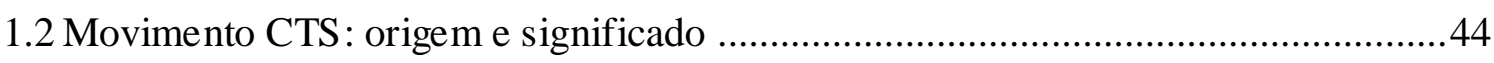

1.3 Questões sociocientíficas: origem, significado e importância ..................................47

1.4 Um olhar sobre a moral nos estudos nacionais e internacionais de QSC ...................56

1.4.1 Estudos investigativos sobre moralidade em artigos de QSC ........................60

1.4.2 Abordagem de QSC e moral em aulas de Ciências ........................................82

1.5 Um olhar sobre as inter-relações CTS, conhecimento e linguagem científica e ética, moral e valores em documentos educacionais para o Ensino Méd io ..........................84

1.5.1 Diretrizes Curriculares Nacionais para o Ensino Médio .................................85

1.5.2 Base Nacional Comum Curricular (versão preliminar) ....................................8

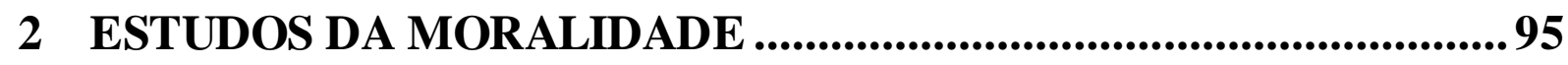

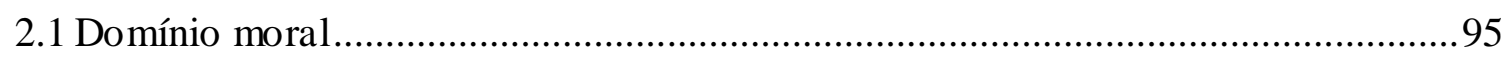

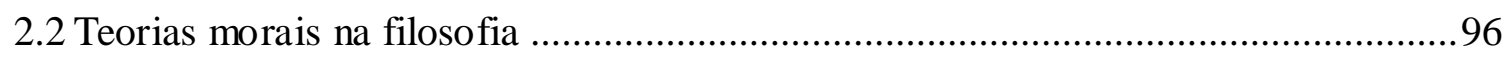

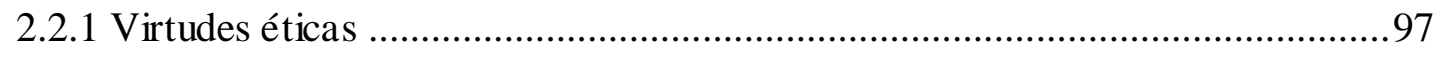

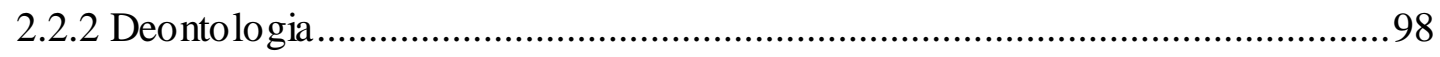

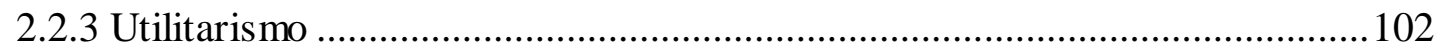

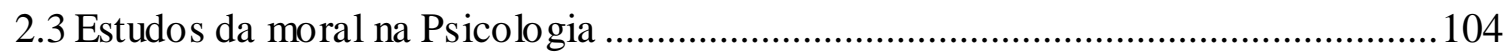

$2.4 \mathrm{O}$ ensino de Ciências e o desenvolvimento moral .................................................. 107

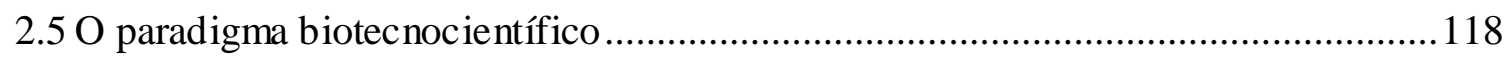

3 PROCEDIMENTOS INVESTIGATIVOS ....................................... 121

3.1 Abordagem metodológica da investigação ......................................................... 121

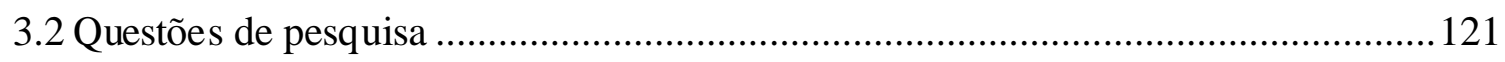

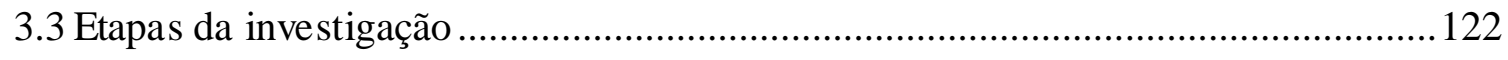

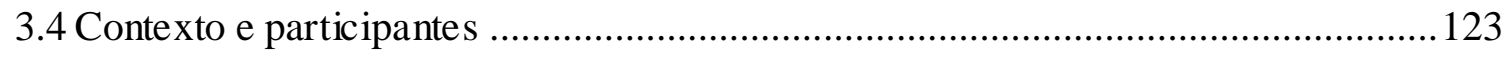

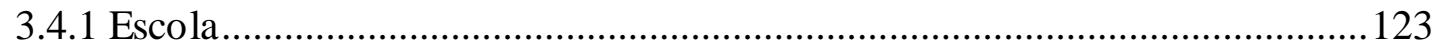

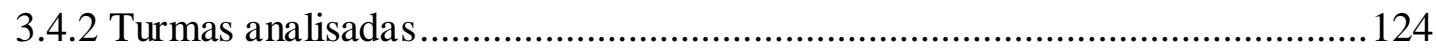

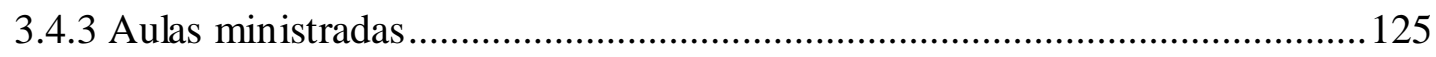

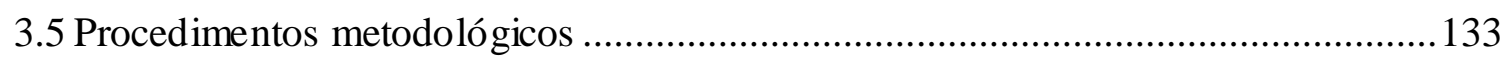


3.5.1 Roteiro para a entrevista individual com os estudantes 134

3.5.2 Questionário. 134

3.5.3 Questões sociocientíficas..... 134

3.5.4 Roteiro para as sessões de discussão em sala de aula ....................................135

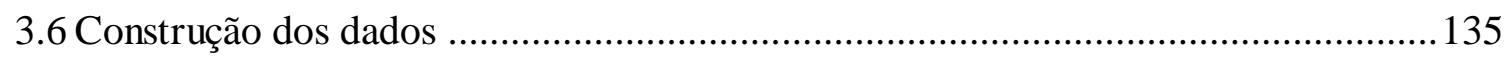

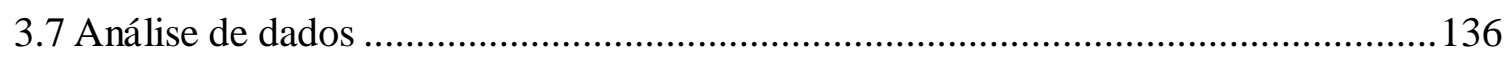

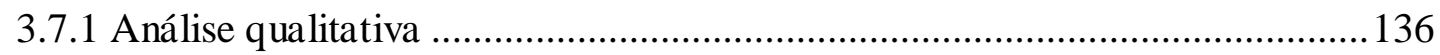

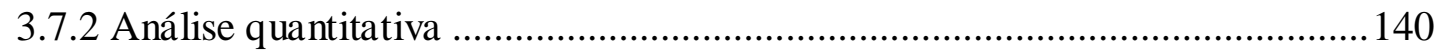

4 RESULTADOS E DISCUSS ÃO ....................................................145

4.1 Análise de aspectos morais dos estudantes no estudo das QSC ..............................145

4.1.1 QSC sobre trans gênico ............................................................................ 145

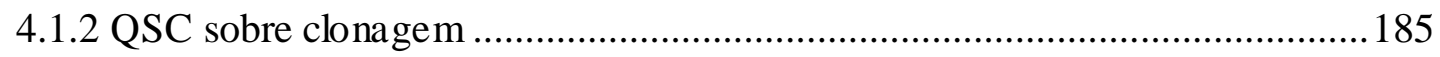

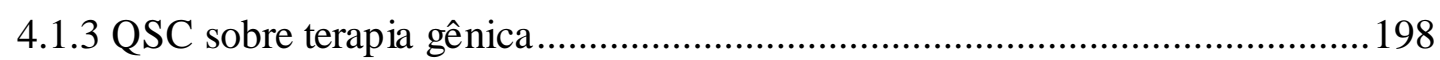

4.2 Reflexões sobre implicações pedagógicas .............................................................212

4.2.1 Desenvolvimento das sequências didáticas de QSC e participação dos alunos nos dilemas

4.2.2 Estratégias didáticas para introdução de QSC, envolvendo aspectos morais .215

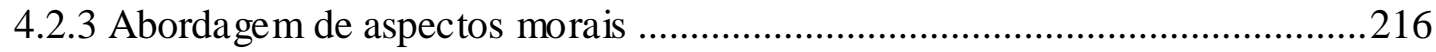

4.2.4 Conhecimento científico, aspectos morais e QSC .......................................2218

4.2.5 Temas de QSC para discussão de aspectos morais e o currículo ....................219

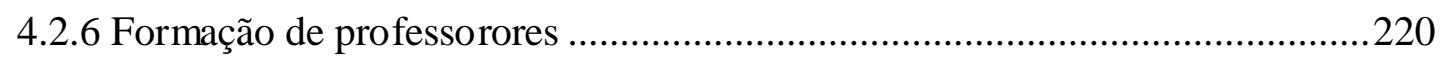

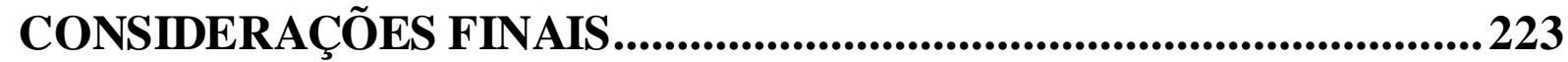

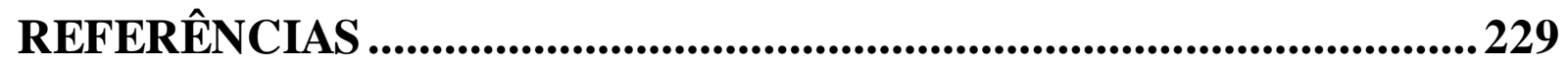

APÊNDICE A - RELAÇÃO DE ARTIGOS SOBRE QUESTÕES

SOCIOCIENTÍFICAS ....................................................................244

APENNDICE B - TERMO DE CONSENTIMENTO LIVRE E

ESCLARECIDO PARA ESTUDANTES ..........................................257

APÊNDICE C - QSC SOBRE MILHO TRANSGÊNICO........................259

APÊNDICE D - QSC SOBRE CLONAGEM REPRODUTIVA ..............261

APÊNDICE E - QSC SOBRE TERAPIA GÊNICA ................................. 263 
APÊNDICE F - QUESTÕES PARA NORTEAR A DISCUSSÃO SOBRE

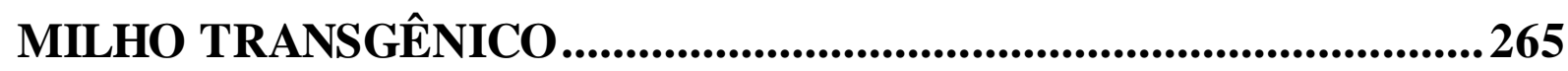
APÊNDICE G - QUESTÕES PARA NORTEAR A DISCUSSÃO SOBRE CLONAGEM REPRODUTIVA..........................................................267 



\section{INTRODUÇÃO}

Minha atuação profissional ao longo dos anos foi voltada às atividades pedagógicas ministrando aulas e acompanhando a vida escolar dos estudantes. Apesar de ter feito mestrado na área de Biotecnologia Genômica, atuo há 20 anos como professora da Educação Básica. Ao longo dessa trajetória, sempre senti falta de momentos para aprofundar leituras e refletir a respeito de situações relacionadas com a formação integral dos educandos.

Quando ingressei no curso de doutorado na Faculdade de Educação da Universidade de Brasîlia o pré-projeto ainda não estava bem definido, por isso, me engajei no grupo de pesquisa do Dr. Wildson Luiz Pereira dos Santos. Foi daí, que veio a possibilidade de atuação no projeto Observatório de Professores da Capes, o qual abriu o caminho para o delineamento deste trabalho. Ao decidir desenvolver investigação sobre questões sociocientíficas (QSC), na revisão de literatura do campo, que havia poucas pesquisas sobre a moral.

Atualmente a educação moral tem sido apontada como imprescindível à formação integral do cidadão, haja vista os avanços da biotecnologia e sua influência nas sociedades. Tais avanços demandam a interpretação de maneira ética ou moral, já que neles estão envolvidos conflitos de valores que nos obrigam a optar por aqueles que deem um sentido mais justo às nossas ações.

No ensino de Biologia nos deparamos com questões que envolvem biotecnologia, como clonagem, células-tronco, transgenia, dentre outras, que se caracterizam por envolver aspectos científicos que por não apresentarem solução satisfatória, quando observadas apenas por esse aspecto, além de dependerem da consideração de vários critérios como, econômico, político, cultural, ambiental e ético ou moral.

Nesse contexto, percebemos que o conhecimento científico não representa o todo das questões. De acordo com Garvey (2010), a ciência explica os fatos, não o que fazer a respeito dos problemas, é nesse ponto, que recorremos também aos nossos valores.

Segundo Callado Moreno (2012), todas as ações humanas são orientadas consciente ou inconscientemente por valores, que são projetos ideais que supõem a eleição de determinadas opções como desejáveis e apreciáveis.

Assim, compreendemos que a tomada de decisão requer escolhas entre alternativas muitas vezes conflitantes, nas quais emerge o componente valorativo, que se apoia nos princípios éticos ou morais do indivíduo e da sociedade. 
A palavra ética provém do adjetivo grego ethike, que origina-se do substantivo ethos que originalmente tinha o sentido de "morada", "lugar em que se vive" e posteriormente passou a significar "caráter", "modo de ser" que se vai adquirindo durante a vida (GONTIJO, 2006).

O termo moral provém do latim mos que foi usado (provavelmente por Cícero) para traduzir o vocábulo ethos, cujo significado era morada dos homens e dos animais. Posteriormente foi ampliando o seu significado para denotar, do ponto de vista coletivo, os costumes, e de um ponto de vista individual, o modo de ser e o caráter (GONTIJO, 2006).

Portanto, segundo a tradição filosófica, os termos moral e ética tiveram a mesma significação em sua origem. Embora, tenha quem apresente diferenciação entre esses termos, podemos considerar que ambos designam o mesmo campo de fenômenos, o mesmo domínio de reflexão, e possuem mesma significação semântica (CANTO-SPERBER, 2005; RICOUER, 2011). A esse respeito Canto-Sperber (2005, p. 35) admite:

vou decepcionar o leitor dizendo que em geral me sirvo dos termos 'moral' e 'ética' como sinônimos. [...] não há nenhuma dúvida sobre o fato de que os termos 'moral' e 'ética' designam o mesmo domínio de reflexão. E para nos referirmos ao tipo particular de atitude que é a reflexão sobre a ação, o bem ou o justo podemos nos servir indiferentemente de qualquer um dos dois termos.

Ricouer (2011, p. 3) pergunta - "preciso distinguir entre moral e ética? A dizer a verdade, nada na etimologia ou na história do uso das palavras o impõe: uma vem do grego, outra do latim, e ambas remetem à ideia dos costumes (ethos, mores)".

Geralmente, quando filósofos utilizam distintos significados o fazem com objetivo específico de denotar diferentes aspectos da vida moral ou, da reflexão moral. Assim, cabe-nos ressaltar que, neste trabalho, consideraremos os termos ética e moral como sinônimos, por acreditarmos que não é nosso objetivo fazer uma distinção entre os mesmos. Da mesma forma, também adotamos nesta tese o termo moralidade como sinônimo de ética e moral, no sentido de se referir à qualidade do que é moral. ${ }^{1}$

Em relação ao termo valor, este possui uma conotação diferente dos vocábulos acima citados, sua origem etimológica (do latim valere) remete à ideia daquilo que vale (ou de merecimento), de robustez, força e poder de um objeto (bem) que se impõe primordialmente à consciência do sujeito. Da relação entre os termos valor, moral e ética originam-se valores morais e valores éticos (PEDRO, 2014).

\footnotetext{
${ }^{1}$ Em consonância com o título da tese, adotaremos o termo moral ao longo do texto, sendo que ao fazermos referência a outros escritos procuramos adotar o termo empregado pelo autor (moral ou ética).
} 
Estudos têm demonstrado que os valores morais não são inatos, nem hereditários, eles se formam e se desenvolvem em função de um complexo sistema de atividades, influências e interações no transcorrer da vida do indivíduo (GONZÁLEZ REY, 1983; GONZÁLEZ REY; MITJÁNS MARTÍNEZ, 1989).

González Rey e Mitjáns Martínez (1989) afirmam que o desenvolvimento da esfera moral humana não pode ser atingido somente pelas normas e informações sobre a qual atuam as organizações e instituições sociais. A moralidade é um processo racional, cognoscitivo e afetivo em que os determinantes atuam por múltiplos canais sobre a individualidade. Dessa forma, assumimos que a educação moral possui um caráter ativo, cujos conteúdos não podem ser impostos ao indivíduo, e sistêmico, na qual todas as organizações e instituições da sociedade são agentes da educação moral.

Os professores em nome da responsabilidade a eles concedida são chamados a atuar na função de transformar o mundo que nos rodeia a partir de pequenas mudanças produzidas nos estudantes e em si mesmos. Analisando a História da Educação observamos que a prática educativa sempre teve conotações morais, estamos falando do poder da educação para a construção de valores e para o aperfeiçoamento humano.

Considerando o caráter ativo da educação moral, é fundamental que o educador seja um orientador que promova a organização de atividades que estimulem a participação ativa dos estudantes. Falar de moral significa enfrentar fatos e acontecimentos que preocupam, inquietam e questionam: fatos que provocam conflitos de valores. Nesse sentido, a educação moral deverá discutir criticamente os recursos morais que possam ser de utilidade na resolução dos conflitos e, dessa forma, deverá ajudar a desenvolver capacidades morais que permitirão a cada sujeito enfrentar crítica e criativamente conflitos de valor (PUIG, 1998).

A partir da exposição acima, surge uma inquietação: por que o ensino de Biologia/Ciências ${ }^{2}$ deve se ocupar com o desenvolvimento moral dos estudantes?

O avanço do conhecimento científico e tecnológico tem sido diretamente influenciado pela economia e política, também tem propiciado o surgimento de questões controversas, que envolvem a saúde, o bem-estar e a vida das pessoas. No campo educacional, quando esclarecidos os valores que permeiam essas questões (quadro moral) elas podem ser utilizadas para o favorecimento do raciocínio moral dos estudantes.

\footnotetext{
${ }^{2}$ A presente tese foi desenvolvida no âmbito do Ensino de Biologia, no entanto, consideramos que as implicações teórico-filosóficas aqui desenvolvidas se aplicam a qualquer disciplina da área das Ciências da Natureza, motivo pelo qual iremos adotar o termo ensino de Ciências, fazendo uso de ensino de Biologia, quando assim se referir a alguma especificidade dessa disciplina.
} 
Segundo Patronis, Potari e Spiliotopoulou (1999) a falta de conhecimento da população, desencadeia um problema de democracia no acesso ao conhecimento e a tomada de decisão. Esse quadro nos coloca diante de um desafio para a educação, mais especificamente para o ensino de Ciências, por que esse deve contribuir para que os estudantes sejam capazes de tomar decisões considerando diferentes aspectos.

Aliado a isso, segue-se o reconhecimento cada vez maior, da importância do letramento científico para a formação cidadã, tomada de decisão, capacidade de analisar, sintetizar e avaliar informações, lidando sensivelmente com as questões morais.

Scientific literacy pode ser traduzido como alfabetização ou letramento. Embora Santos (2007) reconheça que esse termo tem sido adotado por diferentes autores com o mesmo significado, ele distingue alfabetização de letramento semelhante ao que fez Soares (1998). Tendo em vista, que o foco desta tese está na educação científica adotamos o termo letramento científico correspondendo ao significado proposto por Santos (2007) que busca enfatizar sua função social e não apenas o domínio da linguagem científica.

Zeidler (1984) argumenta que, a fim de alcançar o letramento científico, é necessário incluir questões éticas no currículo de Ciências. O autor baseia-se na premissa de que os estudantes têm que tornarem-se conscientes das múltiplas consequências que podem surgir a partir das decisões tomadas sobre um problema social. Nesse contexto, para o autor o letramento científico é mais que ensinar os conteúdos da ciência; ele exige que os estudantes sejam cidadãos capazes de aplicar o conhecimento científico na resolução de problemas sociais.

Para Zeidler e Lewis (2003), o letramento científico ${ }^{3}$ é descrito como necessário para compreender o fenômeno sociocientífico porém, desnecessário e inatingível sem o desenvolvimento de um quadro ético para a tomada de decisão moral.

Aikenhead (2004) defende que o uso do conhecimento científico na tomada de decisão permite que as pessoas assumam responsabilidades sociais esperadas de cidadãos, de tomadores de decisão empregados no serviço público, nos negócios e na indústria. Vários pesquisadores sustentam que a tomada de decisão abrange necessariamente uma ampla gama de outros tipos de conhecimento: valores, tecnologia, ética, civismo, política, direito, economia, políticas públicas etc. (JIMÉNEZ-ALEIXANDRE; PEREIRO-MUÑOZ, 2002; KOLSTØ, 2001a).

Kolstø (2001b) enfatiza que é por meio das experiências que os estudantes poderão desenvolver as atitudes e habilidades necessárias para analisar e efetivamente raciocinarem

\footnotetext{
${ }^{3}$ No original scientific literacy functional.
} 
sobre QSC e sugere que, a fim de ajudar a promover o letramento científico para a cidadania, é útil pensar o ensino sobre questões controversas ou sociocientíficas.

Berkowitz e Simmons (2003) exploraram três domínios educacionais e sua sobreposição: educação do caráter, democrática e científica. A educação do caráter está relacionada ao desenvolvimento de competências sociais e morais de estudantes, incluindo a capacidade de raciocinar sobre questões morais e éticas. A educação democrática refere-se às iniciativas para promover o desenvolvimento dos estudantes como cidadãos responsáveis e competentes para atuarem em uma sociedade democrática. A educação científica deve propiciar a abordagem dos conhecimentos científicos e tecnológicos integrando os outros dois domínios de forma a promover uma compreensão das dimensões morais da ciência e tecnologia e participar de uma reflexão informada sobre ética nesse domínio.

No ensino de Ciências nos deparamos com a necessidade de preparação dos estudantes para avaliar responsavelmente os problemas científicos e tecnológicos produzidos pela sociedade atual, para lidar com questões de valor, para aprender a fazer julgamentos e assumir a responsabilidade por suas próprias vidas e a dos outros. Por isso, destaca-se o relevante papel das QSC para o estabelecimento de discussões que possam contribuir com o desenvolvime nto moral dos estudantes.

Rachels (2006, p. 15) ao expressar sua concepção sobre moralidade como o "esforço em guiar a conduta do indivíduo por meio da razão", ou seja, ser guiado pelas melhores razões para fazer algo, chega à caracterização do que deve ser um agente moral consciente. Ele entende esse agente como aquele que se preocupa de forma imparcial com os interesses de cada um que possa ser afetado por aquilo que ele faça; que analisa o fato e suas implicações; que aceita princípios de conduta depois de examiná-los para constatar sua consistência e, mais ainda, que esteja disposto a agir de acordo com o resultado de suas deliberações. Logo, o papel do indivíduo enquanto agente moral está diretamente relacionado ao pensamento crítico e reflexivo, que é capaz de chegar a tomada de decisão e, a partir disso, fomentar as ações pertinentes no campo desejado.

Como a tomada de decisão em QSC envolve uma dimensão valorativa, então consideramos que o tipo de raciocínio mobilizado pelo indivíduo nesses casos é o raciocínio moral. Sadler (2004a) aponta que o raciocínio moral é um tipo de raciocínio informal que é levado em conta na resolução de dilemas sociocientíficos, considerando que o conhecimento científico subsidie, mas não constitua um fator determinante na tomada de decisão.

Richardson (2014) também descreve o raciocínio moral como uma espécie de 
raciocínio prático, ou seja, um tipo de raciocínio direcionado para decidir o que fazer que envolve a formação de julgamentos morais. Nesse contexto, o raciocínio moral pode ser entendido como sendo o resultado de uma oportunidade para os estudantes utilizarem critérios empíricos, sociais e valorativos em contextos educativos formais e informais por meio do discurso racional.

Nessa perspectiva, espera-se que a educação científica atue na formação para a cidadania e para a tomada de decisão informada que é um dos desafios impostos pelo desenvolvimento da ciência e da tecnologia.

Neste trabalho, consideramos que o desenvolvimento da esfera moral do indivíd uo tem papel fundamental na formação para a cidadania, que a educação científica e a formação cidadã deve se pautar, sobretudo na formação de atitudes e hábitos. Santos (2008) ao pensar uma educação científica e tecnológica humanística afirmou que essa não deve se restringir ao uso e não uso de aparatos tecnológicos, mas que, de fato, seja uma educação centrada na condição existencial voltada para desvelar as possibilidades humanas e valores.

\begin{abstract}
Nes se sentido, uma educação científica e tecnológica humanística buscaria incorp orar ao currículo discussões de valores e reflexões críticas que possibilitassem desvelar a condição humana. Não se trata de uma educação contra o uso da tecnologia e nem uma educação para o uso, mas uma educação em que os alunos possamrefletir sobre a sua condição no mundo frente aos desafios postos pela ciência e tecnologia. (SANTOS, 2008, p. 122).
\end{abstract}

Nos documentos oficiais da área de educação identificou-se a incorporação da ética, moral e de princípios como a responsabilidade, a solidariedade, e autonomia. Esses componentes denotam uma preocupação com o desenvolvimento pessoal dos indivíduos, a base científica e tecnológica na qual devem ser incorporados os componentes socioculturais, com base epistemológica fundada no humanismo. Cabe ressaltar, que o alcance da autonomia moral, pressupõe um papel ativo por parte do sujeito na elaboração de juízos de valor e nas escolhas de cada indivíduo.

Como resposta às rápidas mudanças sociais, a educação científica tem o potencial de permitir nos estudantes o desenvolvimento de habilidades que facilitem conviver em contextos de pluralidade social e moral, na medida em que reforça aspectos de responsabilidade, respeito, solidariedade e justiça, tanto no plano individual, como no coletivo.

Assim, é necessário investigar sobre esse tema para poder auxiliar os professores a pensar as práticas de sala de aula, no sentido de problematizar e aprofundar melhor temas da biotecnologia, suas implicações sociais e morais, por meio de discussões de QSC. 
Com base nessas considerações, a investigação foi realizada por meio de uma pesquisa participante com estudantes do ensino médio de uma escola pública do Distrito Federal. Tendo como objetivo desenvolver sequências didáticas com a discussão de QSC relativas a dilemas de biotecnologia que envolvem aspectos morais ${ }^{4}$, visando caracterizar implicações pedagógic as para tratar questões morais no ensino de Biologia. Foram identificados, então, os aspectos morais adotados pelos estudantes relativos às QSC, antes, durante e depois da discussão dos dilemas, com o propósito de revelar possíveis indicadores da relação entre abordagem de QSC e aspectos morais.

A partir desse objetivo, estabelecemos as seguintes questões de investigação:

- Que aspectos morais orientam a tomada de decisão dos estudantes em relação à QSC sobre temas de biotecnologia?

- Esses aspectos morais se alteram ao se abordar dilemas morais em QSC relativas à biotecnologia?

- Qual a relação entre os conhecimentos científicos específicos de Biologia com o raciocínio moral dos estudantes na tomada de decisão de QSC relativas à biotecnologia?

- Que desafios pedagógicos são enfrentados na introdução de QSC, com o propósito de tratar de questões morais no ensino de Biologia?

- Qual o papel da abordagem de QSC em sala de aula no favorecimento do raciocínio moral dos estudantes?

Em síntese, esta investigação visou fornecer elementos para o entendimento de como desenvolver práticas pedagógicas para discussões de QSC sobre biotecnologia, envolvendo aspectos morais.

Este trabalho de pesquisa foi estruturado em quatro capítulos que representam as etapas pelas quais o estudo se desenvolveu para responder as questões propostas.

No primeiro capítulo, apresentamos um panorama sobre o letramento científico, o movimento Ciência-Tecnologia-Sociedade (CTS) e QSC, o seu papel no ensino de Ciências e contribuição para o desenvolvimento moral ${ }^{5}$. Seguido de uma revisão sistemática sobre as

\footnotetext{
${ }^{4}$ Aspectos morais: categorias de análise que estão no cap. 2, que se referem ao domínio moral, ao raciocínio moral deontológico, utilitarista e ceticismo moral e aos princípios morais adotados pelos estud antes.

5 Entendemos o desenvolvimento moral como um processo de transformação qualitativa na autonomia moral do sujeito, na adoção de princípios com referência valorativa e um senso de justiça mais equilibrado, fundamentado em inter-relações mais complexas entre os elementos presentes em uma determinada situação. Para tanto, a ação educativa não pode se basear exclusivamente na aquisição de conhecimento informativo sobre problemáticas morais e sociais, mas no trabalho com problemas morais que sejam próximos da realidade dos estudantes.
} 
pesquisas relacionadas às QSC e a moral em 27 revistas da área de ensino de Ciências nacionais e internacionais, no período de 1997 a 2013. Essa revisão possibilitou a elaboração de um panorama das principais questões e resultados de pesquisas relacionadas às QSC e a moral no ensino de Ciências, que se constituiu como ferramenta para a fundamentação teórica, elaboração e respostas das questões presentes neste estudo.

Nesse capítulo, também foram analisadas as Diretrizes Curriculares Nacionais para o Ensino Médio (DCNEM) e a versão preliminar da Base Nacional Comum Curricular (BNCC). Esses documentos foram analisados com o objetivo de evidenciar a presença de uma abordagem direcionada para as inter-relações CTS, QSC, ética, moral, valores e seus significados.

O segundo capítulo propõe-se a oferecer uma visão da moral a partir de contribuições do campo da psicologia e da filosofia. Este capítulo apresentará, então, uma caracterização acerca do domínio moral, raciocínio moral e a descrição de teorias morais que têm sido comumente utilizadas no estabelecimento e análise de quadros morais, caracterizando o que as aproximam e o que as distanciam.

No terceiro capítulo, serão relatadas a abordagem metodológica, a contextualização da investigação, o desenho metodológico, sujeitos e instrumentos que foram utilizados nesta pesquisa. Para balizar a compreensão das implicações metodológicas deste design de pesquisa, inicialmente a conceitualização de pesquisa participante foi revisada. Seguindo-se, então, a descrição dos procedimentos específicos que foram adotados na construção dos dados do presente estudo e das proposições norteadoras de sua análise.

No quarto capítulo, apresentaremos as análises realizadas de caráter quanti-qualitativo. Inicialmente elaborou-se uma análise estatística descritiva dos resultados com o objetivo de caracterizar a população do estudo, bem como sua percepção sobre as QSC apresentadas quanto a algumas variáveis que emergiram nos discursos relacionadas aos aspectos morais, seguida de uma análise qualitativa dos referidos discursos.

No último capítulo, elaborou-se uma síntese do estudo destacando as respostas e desdobramentos referentes as questões de pesquisa, assim como as recomendações decorrentes dos resultados.

Portanto, espera-se contribuir para o entendimento de como discussões de QSC no ensino de Biologia podem contribuir para o favorecimento do raciocínio moral dos estudantes, visando caracterizar implicações pedagógicas para tratar QSC com aspectos morais. 




\section{QUESTÕES SOCIOCIENTÍFICAS NO ENSINO DE CIÊNCIAS}

Um campo de estudo no ensino de Ciências que anteriormente era desenvolvido no âmbito do movimento CTS é o de investigações sobre QSC. Este trabalho se apoia no pressuposto de que as QSC envolvem o conhecimento científico e podem ser consideradas a partir de uma variedade de perspectivas, como: econômicas, sociais, culturais, ambientais, dentre outras, que não possuem conclusões simples, e envolvem a moral. Nesse contexto, as QSC ganham cada vez mais importância no ensino de Ciências, uma vez que carregam em si a potencialidade de articulação entre a dimensão social e científica dos conhecimentos.

Estudos apontam que as QSC podem servir a diversos objetivos, Sadler e Zeidler (2004) citam alguns deles: forma de tornar a aprendizagem científica mais relevante para a vida dos estudantes; apreciação sobre a natureza da ciência; na melhoria da argumentação dialógica; na capacidade de avaliar dados científicos e informações; e como um componente importante do letramento científico.

Neste capítulo, apresentamos uma revisão dos pressupostos do letramento científico, do movimento CTS e de QSC na educação em Ciências, por considerarmos que essas correntes se complementam ao incorporarem concepções teóricas e metodológicas que estão na base das QSC. Além, de terem como foco a formação para a cidadania e preparação para a tomada de decisão responsável.

Nesse contexto, compreendemos que o conhecimento científico não é o único elemento a ser considerado na tomada de decisão, mas que, de fato, essa possui um componente valorativo que considera o certo e o errado, o bom ou ruim, o justo ou injusto, e sendo assim, é realizada com base em juízos de valor que envolve a moral do indivíduo e da sociedade.

O ensino de Ciências comprometido com a formação do cidadão crítico deve colaborar direta ou indiretamente com o desenvolvimento moral, com a construção de uma sociedade mais justa, baseada no respeito mútuo, diálogo e solidariedade, através de uma tomada de decisão crítica e atuante.

Também, apresentaremos uma revisão teórica que teve como objetivo fornecer um panorama das pesquisas nacionais e internacionais da área de ensino Ciências sobre QSC e o espaço que a moral ocupa nessas pesquisas.

Além das pesquisas na área de ensino de Ciências, da mesma forma procuramos evidências nos documentos oficiais da educação para o Ensino Médio (EM): Diretrizes 
Curriculares Nacionais (DCNEM) e Base Nacional Comum Curricular (BNCC) em sua versão preliminar, de uma abordagem direcionada para as inter-relações CTS, QSC, ética e moral e seus significados. O foco da pesquisa empírica deste trabalho foi o EM, por isso, a ênfase se deu na análise dos documentos oficiais desse nível da educação básica.

\subsection{Letramento científico: origem e significado}

Diversos pesquisadores vêm tentando consolidar uma síntese sobre o significado de letramento científico para a comunidade de educação em Ciências.

Laugskch (2000) fez uma ampla revisão sobre letramento científico apresentando vários aspectos, dentre eles, o contexto histórico do desenvolvimento do termo. Segundo o autor, o termo apareceu impresso pela primeira vez em uma publicação intitulada Science Literacy: Its Meaning for American Schools de Hurd (1958). Para ele, o interesse no letramento científico durante o final da década de 1950 deu-se, provavelmente, a uma preocupação da comunidade científica norte-americana sobre o apoio público para a ciência, a fim de dar uma resposta ao lançamento do Sputnik soviético.

Ao longo de seis décadas vários pesquisadores (ver, por exemplo, AGIN, 1974; BAKER, 1991; BYBEE, 1997; DEBOER, 1991; GABEL, 1976; GARFIELD, 1988; HURD, 1998; LAYTON, JENKINS e DONNELLY, 1994; PELLA, O’HEARN e GALE, 1966 e ROBERTS, 1983), fizeram uma série de tentativas de consolidação do letramento científico como um conceito, dentre inúmeros outros, constituindo, dessa forma, uma literatura substancial e diversificada.

Desde o surgimento do termo letramento científico até os dias atuais esse tema tem sido amplamente discutido na literatura, embora nem sempre com o mesmo significado (BYBEE, 1997). Como um termo polissêmico, o letramento científico tem a possibilidade de carregar diversos significados e, ao nível da escola, definir as intenções da educação científica.

Em seu trabalho, Hurd (1958) defende a necessidade de elaboração de um novo currículo de ciências para as escolas americanas, visando o enfretamento da descontinuidade existente entre o desenvolvimento científico e social, e a preparação de estudantes comprometidos com as transformações sociais provocadas pelo desenvolvimento científico e tecnológico.

Hurd (1958, p. 14, tradução da autora) apresentava os seguintes questionamentos: 
[...] será possível desenvolver uma educação essencial para o avanço científico no âmbito de uma sociedade livre? Pode uma filosofia da educação e um currículo serem desenvolvidos de modo a preparar os jovens para um mundo industrializado?

[...] a necessidade é de uma perspectiva de educação compatível com as forças da ciência que agora estão moldando os caminhos dos homens.

Em uma análise de cerca de 100 artigos Pella, O’hearn e Gale (1966, p. 206, tradução da autora) apresentaram uma base empírica para a definição de letramento científico. Os seis elementos definidores mais comuns do termo foram: inter-relações entre ciência e sociedade (67); ética da ciência (58); natureza da ciência (51); conhecimento conceitual (26); d) ciência e tecnologia (21) e ciência nas ciências humanas (21). A partir dos resultados os autores concluíram que um indivíduo cientificamente letrado deve possuir compreensões acerca dos: conceitos básicos em ciência; da natureza da ciência; da ética que controla o trabalho dos cientistas; das inter-relações entre ciência e sociedade; das relações entre a ciência e as humanidades; e das diferenças entre a ciência e a tecnologia.

Ainda, a partir da análise anterior Pella, O'Hearn, e Gale (1966) notaram que havia vários objetivos principais associados com ensino voltado para o letramento científico. Entre eles, destacam-se a preparação de cientistas e engenheiros, a de técnicos e a da população em geral. Essa foi uma das primeiras referências que apontaram a possibilidade de mais de um tipo de letramento científico.

Shen (1975, p. 45-46, tradução da autora) sugeriu três categorias de letramento científico: prático, cívico e cultural. Por letramento científico prático, o autor significou a "posse do tipo do conhecimento científico que pode ser usado para ajudar a resolver problemas práticos na vida das pessoas". Isto é, o conhecimento que atende às necessidades humanas básicas relacionadas com a alimentação, saúde e abrigo. O cívico refere-se ao conhecime nto essencial que as pessoas necessitam para compreender as políticas públicas. Essa categoria de letramento científico tem como objetivo conscientizar os cidadãos sobre os problemas sociais relativos à ciência e à tecnologia com o objetivo de levá-los a participar do processo de decisão sobre questões envolvendo saúde, energia, alimentação, recursos naturais, ambiente e comunicação. A categoria cultural significa o conhecimento que os indivíduos adquirem para transpor as diferenças entre as culturas cientifica e humanística.

Hodson $\left(2003^{6}\right.$, apud HODSON, 2004, p. 3, tradução da autora) propõe que o letramento científico pode ser abordado em quatro níveis.

\footnotetext{
${ }^{6}$ HODSON, D. Time for action: Science education for an alternative future. International Journal of Science Education, v. 25, n. 6, p. 645- 670, 2003.
} 
Nível 1: refere-se ao reconhecimento do impacto das mudanças científicas e tecnológicas na sociedade e que a ciência e tecnologia são incorporadas culturalmente. Nível 2: reconhece que as decisões sobre desenvolvimento científico e tecnológico são tomadas na busca de interesses particulares e estão ligadas à dis tribuição de riqueza e poder.

Nível 3: está relacionado à formulação de determinados pontos de vista e elaboração de posições de valor correspondentes .

Nível 4: a preparação para ação sociopolítica.

DeBoer (2000) aponta que o conhecimento acerca do letramento científico está aberto e em constante mudança. É orgânico, não estático. Seus parâmetros são tão amplos, que não há nenhuma maneira de dizer quando ele foi alcançado. Não pode haver nenhum teste de letramento científico porque não há um corpo de conhecimento que possa legitimamente definilo. Criar um teste seria criar uma ilusão. O objetivo do letramento científico é alcançado quando o público aprende sobre ciência e o empreendimento científico, das diferentes maneiras que podem ser realizadas.

Roberts (2007) postulou a existência de duas visões globais denominadas visão I e visão II. Na visão I o objetivo do ensino de Ciências é a compreensão acerca dos produtos e processos da ciência. A visão II, por sua vez, enfatiza uma abordagem que incorpora a tomada de decisão em situações reais que apresentam um componente científico, onde é possível atuar como cidadãos.

No contexto brasileiro, o letramento científico tem sido estudado por pesquisadores como Brandi e Gurgel (2002), Chassot (2003), Lorenzetti e Delizoicov (2001), Sasseron (2008), Santos (2002). Além disso, encontramos na literatura nacional da área de ensino de Ciências, diferentes expressões que visam formação cidadã dos estudantes para o uso dos conhecimentos científicos e sua utilização nas diferentes esferas de sua vida. São elas: "Letramento Científico" (ver, por exemplo, MAMEDE e ZIMMERMAN, 2005; SANTOS, 2002), "Alfabetização Científica" (ver, por exemplo, AULER; DELIZOICOV, 2001; BRANDI; GURGEL, 2002; CHASSOT, 2000; LORENZETTI; DELIZOICOV, 2001) e também aqueles que usam a expressão "Enculturação Científica" (ver, por exemplo, CARVALHO; TINOCO, 2006; MORTIMER; MACHADO, 1996).

Sasseron e Carvalho (2011) explicam as diferentes expressões. No caso da "Enculturação Científica" parte-se do princípio da incorporação das culturas religiosa, social e histórica as noções, ideias e conceitos científicos, uma vez que, os estudantes trazem consigo essas diferentes culturas. No caso do termo "Letramento Científico" a escolha é fundamentada no significado do termo conforme Soares $(1998$, p. 47) que se refere ao letramento como 
"estado ou condição de quem não apenas sabe ler e escrever, mas cultiva e exerce práticas sociais que usam a escrita".

Em tese intitulada Alfabetização científica no ensino fundamental: estrutura e indicadores deste processo em sala de aula, Sasseron (2008, p. 65) apresenta o que denominou como "Eixos Estruturantes da Alfabetização Científica", ou seja, "habilidades classificadas como necessárias de serem encontradas entre os alfabetizados cientificamente". O primeiro eixo está relacionado à compreensão básica de termos, conhecimentos e conceitos científicos fundamentais, e tem como fundamento a construção de conhecimentos científicos necessários para que os estudantes possam aplicá-los em situações diversas. O segundo apresenta-se vinculado à compreensão da natureza da ciência e dos fatores éticos e políticos que circundam sua prática, tendo como fundamento à ideia de ciência como um corpo de conhecimentos em constante transformação. O terceiro refere-se ao entendimento das relações existentes entre ciência, tecnologia, sociedade e meio-ambiente, caracterizando-se pelo reconhecimento das inter-relações entre as esferas propostas pela autora.

Diversos especialistas em todo mundo têm se referido ao letramento científico e tecnológico como finalidade central do ensino de Ciências. Segundo Acevedo Diaz, Vásquez Alonso e Manassero Mas (2003) há muitas formas de entender o letramento científico e tecnológico no sistema escolar, que dependem das próprias concepções ideológicas, sociológicas e epistemológicas e das finalidades e objetivos do ensino de Ciências.

Entende-se que o conceito de letramento científico é polissêmico e que se traduziu como um movimento pela melhoria da qualidade da educação científica, trazendo como um dos seus componentes a formação de cidadãos críticos capazes de tomar decisões em relação a questões que envolvam o conhecimento científico e tecnológico.

Compreende-se que, nos âmbitos nacional e internacional, a produção acadêmica apresenta uma concordância no que diz respeito às finalidades almejadas com a educação científica. Esse campo tem se caracterizado pela descrição e prescrição, mais do que pela fundamentação empírica das ideias, ou seja, os autores relatam suas concepções e listam diversas habilidades para que as pessoas possam ser consideradas cientificamente letradas.

Entretanto, não existe um único caminho correto para ensinar Ciências e cada pessoa desenvolve conhecimentos e habilidades à sua maneira, ou seja, a trajetória para a aprendizagem é um percurso individual, mas o direito de aprender é um valor coletivo. Atender a essa propriedade exige capacidade de responder adequadamente a algumas questões: a) Que objetivos se pretende alcançar com o ensino de Ciências? b) É possível antecipar como o 
estudante fará uso desse conhecimento em sua vida? c) Esses conhecimentos permitirão ao estudante ampliar sua interlocução dentro da sociedade? d) Ensinar Ciências visa a formação de novos cientistas ou a preparação para a superação de estágios de aprendizagem que levem ao ensino superior em qualquer área?

Nesse contexto, o papel das escolas é decidir o que ensinar e como ensinar com base no interesse dos estudantes, na experiência dos professores e em outras considerações importantes.

\subsection{Movimento CTS: origem e significado}

Neste tópico apresentaremos o movimento CTS e sua importância como impulsionador de questionamentos críticos e reflexivos acerca do contexto científico, tecnológico e social, em especial, destaca-se a sua relevante contribuição na educação científica.

A sociedade contemporânea tem sido transformada pelo progresso científico e tecnológico que vem produzindo mudanças nos níveis econômico, político e social. Como alternativa contrária à visão racionalista da ciência e da tecnologia, em um contexto de crítica ao modelo desenvolvimentista, surgiu uma nova forma de entender as relações entre a ciência, tecnologia e sociedade expressa no movimento CTS (SANTOS, 2011).

Iniciado na década de 1960 o movimento CTS apresenta um perfil interdisciplinar, que teve sua origem em correntes de investigação na filosofia e sociologia da ciência. Segundo Bazzo e Colombo (2001, p. 93) com a preocupação de "tratar a ciência e a tecnologia, tendo em vista suas relações, consequências e respostas sociais".

No campo educacional, os pressupostos do movimento CTS têm servido como base para construir currículos em vários países, em especial os de Ciências, dando prioridade ao letramento em ciência e tecnologia com interface no contexto social, de formação para a cidadania (PINHEIRO et al., 2007; SANTOS, 2011).

Na educação científica esse movimento, segundo Auler (2007, p. 1) assumiu como objetivos:

promover o interesse dos estudantes em relacionar a ciência com aspectos tecnológicos e sociais, discutir as implicações sociais e éticas relacionadas ao uso da ciência e datecnologia (CT), adquirir uma compreensão da natureza da ciência e do trabalho científico, formar cidadãos científica e tecnologicamente alfabetizados capazes de tomar decisões informadas e desenvolver o pensamento crítico e a independência intelectual. 
Para Santos (1998, p. 25) o principal objetivo educacional da educação CTS é o “desenvolvimento de uma cidadania responsável”, caracterizada pelo autor como:

[...] uma cidadania individual e social para lidar com problemas que têm dimensões científicas e tecnológicas, num contexto que se estende para além do laboratório e das fronteiras das disciplinas. Tornar a Ciência revestida de mais significado para o aluno, de forma a prepará-lo melhor para lidar com as realidades da vida atual e para poder planificar o seu próprio futuro, é uma das suas as pirações básicas.

Ao considerarmos os objetivos do movimento CTS na educação científica, é possível identificar convergências entre estes e os objetivos do letramento científico, como observado por Santos (2002, p. 35):

o objetivo de formação para a cidadania no ensino de ciências insere-se dentro do contexto do movimento de letramento em ciência e tecnologia, LCT. O letramento em ciência e tecnologia, LCT, tem sido as sociado a estudos de compreensão pública da ciência, ciência para todos e educação em ciência - tecnologia - sociedade, CTS.

Gallagher (19717, p. 337 apud AIKENHEAD, 2003, p. 2, tradução da autora) propôs uma nova meta para o ensino de Ciências: "para os futuros cidadãos em uma sociedade democrática, a compreensão das inter-relações CTS podem ser tão importantes quanto à compreensão dos conceitos e processos da ciência".

Waks (1990, p. 43, tradução da autora) afirma que o propósito da educação CTS é:

promover o «letramento em ciência e tecnologia», de maneira que se capacite os cidadãos a participar no processo democrático de tomada de decisões e se promova a ação cidadã encaminhada à resolução de problemas relacionados com a tecnologia na sociedade industrial.

Waks (1990) nesse trecho refere-se à necessidade do letramento científico como propósito da educação CTS voltado à formação para a cidadania, bem como a participação consciente no processo democrático de resolução de problemas resultantes do avanço científico e tecnológico.

Em outro momento, Waks (1990) propõe unidades curriculares que possam integrar programas de ciência e tecnologia ou cursos independentes, mas que devam contemplar cinco fases com ênfase na preparação para a cidadania e para a tomada de decisão:

(1) formação de atitudes de responsabilidade pessoalem relação ao ambiente natural e com a qualidade de vida; (2) tomada de consciência e investigação de temas CTS específicos, focados tanto no conteúdo científico e tecnológico, como nos efeitos das

\footnotetext{
7 GALlAGHER, J. A broader base for science teaching. Science Education, v. 55, p. 329-338, 1971.
} 
distintas opções tecnológicas sobre o bem-estar dos indivíduos e o bem comum; (3) tomada de decisão com relação a essas opções, levando em consideração fatores científicos, técnicos, éticos, econômicos e políticos; (4) ação individual e social responsável direcionada a levar à prática o processo de estudo e tomada de decisão, geralmente em colaboração com grupos comunitários (por exemplo, «oficinas científicas», grupos ecologistas, etc.); e (5) generalização das considerações mais amplas de teoria e princípio, incluindo a natureza sistêmica da tecnologia e seus impactos sociais e ambientais, a formulação de políticas nas democracias tecnológicas modernas e os princípios éticos que possam guiar o estilo de vida e as decisões políticas sobre o desenvolvimento tecnológico. (WAKS, 1990, p. 43-44, tradução da autora).

A formação para a cidadania foi incorporada à educação científica no âmbito dos estudos CTS. Entretanto, ao longo do tempo, diversos trabalhos começaram a adotar a denominação CTS com diferentes concepções, atribuindo, dessa forma, novos significados ao que antes se caracterizava como discussões sobre o papel e as implicações da ciência na sociedade.

De acordo com Santos (2011), alguns estudos foram realizados buscando evidenciar esses significados. Auler e Delizoicov (2001) classificaram-nos em duas visões, uma reducionista e outra ampliada, utilizando como elemento de análise o entendimento sobre as forças de poder que envolvem a tomada de decisão. Gonzáles Garcia et al. (1996) identificaram três modalidades de implementação: introdução de CTS nos conteúdos das disciplinas de Ciências, ciência vista por meio de CTS e programas CTS puros. Fensham (1988), Solomon (1993), Aikenhead (1994) e Yager (1993), não obstante, expressaram uma preocupação com o desenvolvimento de ações relacionadas às questões ambientais.

Santos (2011, p. 37) afirma que há várias denominações para a educação científica e para CTS. Contudo, apesar de propósitos em comum, esses diferentes "slogans" recebem influências ideológicas que os diferenciam, portanto, cada um deve esclarecer o significado que deseja atribuir.

O movimento CTS tomou diferentes rumos na sua trajetória histórica, contudo permanece ativo no âmbito da educação científica e no ensino de Ciências. Constituem objetivos desse movimento a formação para a cidadania e a tomada de decisão responsável como forma de construção de uma sociedade mais justa e igualitária. Para o alcance desses objetivos, faz-se necessário um ensino de Ciências mais comprometido e problematizador da realidade, onde a aprendizagem seja mais significativa para o estudante.

Cabe ressaltar, que os pressupostos do movimento CTS de formação para a cidadania e de atitudes de responsabilidade pessoal e social, estão intimamente relacionados ao desenvolvimento da autonomia moral do indivíduo. Considera-se que a autonomia moral seja 
a capacidade de um indivíduo tomar uma decisão baseada nas informações disponíveis, tendo em conta a responsabilidade moral e social dessa ação.

\subsection{Questões sociocientíficas: origem, significado e importância}

Neste tópico apresentamos as QSC, sua origem e importância no contexto do ensino de Ciências, e sua relação com a moral.

Questões controversas como: relações familiares, pobreza, raça, questões de gênero, leis e ordem, foram introduzidas no currículo de escolas secundárias na Inglaterra nos anos 1970, no intitulado Projeto Curricular Humanidades. Já na década de 1980 priorizou-se educação multicultural. Dada a importância das questões controversas, nos anos 2000 houve um impulso com a sua introdução nas recomendações curriculares específicas para o ensino de Ciências (LEVINSON, 2006).

Em revisões desenvolvidas desde 1992 por Santos (1992 e 2011), Santos e Mortimer (2000), Santos e Schnetzler (2010), sobre movimento de educação CTS no ensino de Ciências, na literatura internacional e nacional foram encontradas diversas citações da introdução de QSC nesse campo (ver, por exemplo, AIKENHEAD, 1994; KORTLAND, 1996; PEDRETTI, 1997 e 2003; PEDRETTI et al., 2008; RAMSEY, 1993; SOLOMON, 1990, 1992, 1993). Assim como, são encontrados diversos estudos sobre QSC que não fazem menção ao movimento CTS (ver, por exemplo, CROSS; PRICE, 1996; GEDDIS, 1991; OULTON; DILLON; GRACE, 2004; RATCLIFFE, 1997; RATCLIFFE; GRACE, 2003; REIS; GALVÃO, 2004; SADLER; ZEIDLER, 2004; SIMONNEAUX, 2008; SIMONNEAUX; SIMONNEAUX, 2009; ZEIDLER et al., 2002, 2005).

Nos Estados Unidos, Zeidler et al. (2002) apresentaram a proposição de QSC no ensino de Ciências, sugerindo que a abordagem CTS poderia ser remodelada devido à possibilidade de consideração do desenvolvimento moral e ético dos estudantes. Além disso, embora alguns objetivos da educação CTS coincidam com os das QSC, de acordo com Zeidler et al. (2005), o movimento das QSC também está associado, entre outros motivos à necessidade de um quadro teórico pedagógico que dê suporte aos objetivos didáticos da proposta CTS.

Santos (2011) afirma que o estudo das QSC que, anteriormente, eram tratadas pelos estudos no campo CTS, têm promovido um avanço na elaboração de propostas pedagógicas, mas que deixa a desejar na elaboração de materiais curriculares que envolvam todo o conteúdo como se tem no campo CTS. Além disso, esses estudos não têm coberto toda a gama de aspectos contemplados pelos estudos curriculares de CTS, um exemplo disso, está nas complexas 
questões multidisciplinares, como as de natureza política que não são suficientemente contempladas nos estudos das QSC.

No Brasil, Santos e Mortimer (2009) defenderam a incorporação de aspectos sociocientíficos $^{8}$ (ASC) em uma perspectiva humanística ao ensino de Ciências, como uma orientação para o letramento científico. Esses autores explicaram que tais aspectos se referem às questões ambientais, políticas, econômicas, éticas, sociais e culturais relativas à ciência e à tecnologia.

QSC são apresentadas por Sadler e Zeidler (2004) como dilemas sociais com informações conceituais, procedimentais ou tecnológicas da ciência, são contenciosas por natureza, podem ser consideradas a partir de uma variedade de perspectivas, não possuem conclusões simples e envolvem a moral.

Vários autores têm sugerido a inclusão de QSC no ensino de Ciências (ver, por exemplo, KOLSTØ, 2001a e b; RAMSEY, 1993; RATCLIFFE, 1998; RATCLIFFE; GRACE, 2003; RUBBA, 1991; ZEIDLER et al., 2005).

As QSC têm sido recomendadas no ensino de Ciências com diferentes objetivos. Ratcliffe (1998, p. 4, tradução da autora) agrupou de acordo com os seguintes aspectos:

1) relevância - encorajar os estudantes a relacionar suas experiências escolares em ciências com problemas de seu cotidiano e desenvolver responsabilidade social; 2) motivação - despertar maior interesse dos estudantes pelo estudo de ciências; 3) comunicação e argumentação - ajudar os estudantes a verbalizar, ouvir e argumentar; 4) análise - ajudar os estudantes a desenvolver raciocínio com maior exigência cognitiva; e 5) compreensão - auxiliar na aprendizagem de conceitos científicos e de aspectos relativos à natureza da ciência.

Os pesquisadores da área têm relatado o uso dessas questões com várias finalidades no ensino de Ciências. Zeilder et al. (2005, p. 361, tradução da autora) identificaram quatro áreas de importância pedagógica para as QSC (Figura 1):

(1) questões da natureza da ciência - incluem orientações epistemológicas sobre a natureza e influência da ciência; (2) questões discursivas em sala de aula - enfatizam papel desempenhado pelo discurso nas interações entre pares e seu impacto sobre o raciocínio; (3) questões culturais - destacam-se por apresentar as pectos pluralistas e sociológicos das salas de aula; e (4) questões baseadas emcasos - reforçam a posição de que, a fim de formar cidadãos cientificamente letrados deve-se considerar o desenvolvimento ético e moral dos estudantes e envolveros estudantes comquestões e problemas que os levem a ponderar e usar tanto seu intelecto como seu caráter.

\footnotetext{
${ }^{8}$ Esses autores adotaram o termo em sua tese as pectos sócio-científicos (ASC), uma vez que naquela época não se tinha ainda no Brasil estudos de QSC, mas existia uma preocupação de inserção curricular de temas sociocientíficos que eram abordados eventualmente pelos professores. Atualmente eles têm se dedicado a estudos de QSC e, por is so, tem preferido es se termo.
} 
Figura 1 - Elementos sociocientíficos da alfabetização científica funcional

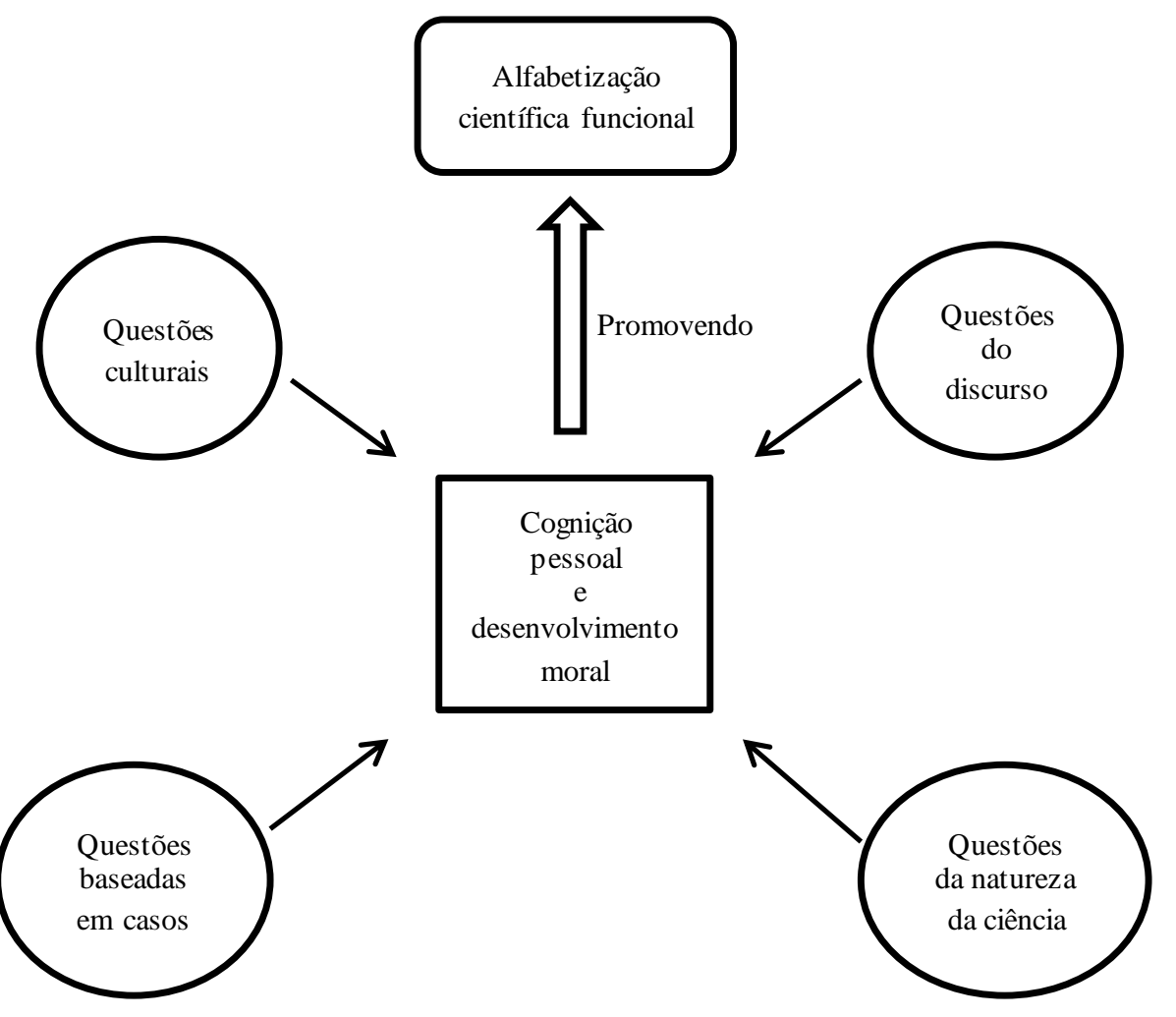

Fonte: Zeidler et al. (2005, p. 361, tradução da autora).

Considerando que a tomada de decisão e o exercício da cidadania na vida real exigem a formação de cidadãos dotados de conhecimentos e capacidades para avaliar os problemas que o desenvolvimento científico e tecnológico tem produzido, nesse contexto as discussões com QSC assumem um importante papel.

Por estarem relacionadas ao conhecimento científico e conjugarem possibilidades de análise e julgamento de diversos critérios, dentre eles, social, econômico, político, ambiental, cultural propiciando o exercício do pensamento reflexivo e crítico, de forma que os estudantes possam tomar decisões ponderadas, fazerem suas escolhas fundamentadas na análise dos elementos envolvidos nas questões.

Na tomada de decisão emerge o componente valorativo e, por sua vez a moralidade do indivíduo ao escolher o "melhor" cenário, aquele que traga mais benefícios, o mais justo, o mais virtuoso. Esses cenários, muitas vezes reais, fazem o estudante experimentar a complexidade da vida. Nesse sentido, as QSC têm constituído importante perspectiva de pesquisa na área de ensino de Ciências.

Apresentamos a seguir as linhas atuais de pesquisa relevantes para a exploração das QSC no ensino de Ciências, agrupadas em seis categorias, de acordo com Sadler e Zeidler 
(2004).

a) Apreciação da natureza da ciência

Pesquisas têm sido conduzidas buscando explicar se os estudantes integram questões acerca da natureza da ciência na tomada de decisão (ver, por exemplo, BELL; LEDERMAN, 2003; KHISHFE; LEDERMAN, 2006; SADLER; CHAMBERS; ZEIDLER, 2004; ZEIDLER et al., 2002).

Khishfe e Lederman (2006) investigaram a influência de duas abordagens pedagógicas na promoção de um entendimento mais informado sobre a natureza da ciência (NOS) entre 42 estudantes. Os participantes foram separados em dois grupos: um recebeu instrução explícita sobre a natureza da ciência e o outro não. A comparação entre os dois grupos mostrou que houve uma pequena diferença no grupo que recebeu instrução explícita sobre a natureza da ciência. Por outro lado, houve melhora na visão dos integrantes do grupo que não recebeu instrução sobre a natureza da ciência. Portanto, os resultados globais não forneceram evidência conclusiva em favor de uma abordagem sobre a outra.

Zeidler et al. (2002) demonstraram que os estudantes que apresentam concepções relativistas da ciência provavelmente consideram o conteúdo científico irrelevante na tomada de decisão com QSC. Esses autores apontaram para uma tendência à distorção de dados, provas, e até mesmo do conhecimento que está disponível com a finalidade de apoiar os pontos de vista em relação à questão. Essa pesquisa que relacionou às QSC à natureza da ciência confirma que os estudantes tomaram decisão com base em aspectos pessoais e não em uma análise das provas apresentadas. Esse padrão de respostas sugeriu que, para alguns estudantes, o mérito científico (por exemplo, provas, dados) e poder de persuasão não eram sinônimos. A fim de apreciar plenamente a natureza empírica da ciência, os estudantes devem compreender o que constituem os dados e como eles podem ser utilizados no processo de tomada de decisão.

Bell e Lederman (2003) ao examinarem os padrões de raciocínio de professores universitários de diversas áreas (educadores de Ciências, filósofos da ciência e cientistas) em QSC, encontraram padrões de raciocínio semelhantes entre esses grupos, com maior ênfase no raciocínio baseado em provas científicas. Embora os participantes do estudo tivessem opiniões variadas acerca da natureza da ciência, as estratégias de tomada de decisão sobre questões da ciência e da tecnologia, não produziram padrões discerníveis para visualizações sobre natureza da ciência. Apesar de todos esses indivíduos terem apresentado algum grau de raciocínio "superficial" baseado em evidências, a principal influência orientadora de suas decisões foram 
valores pessoais, fatores relacionados à moral ou à ética e considerações sociais. Segundo esses autores, o desenvolvimento moral é um fator de interesse na avaliação de estratégias de tomada de decisão em QSC.

b) Melhoria na argumentação

Umas das áreas que tem se destacado é a pesquisa referente à argumentação sociocientífica. Alguns autores como Driver, Newton e Osborne (2000); Osborne, Erduran e Simon (2004), Patronis, Potari e Spiliotopoulou (1999); Sadler e Donnelly (2006); Zohar e Nemet (2002) têm desenvolvido pesquisas com esse enfoque.

Zeidler et al. (2005) enfatizaram que o discurso apresenta um papel crucial no desempenho das interações entre pares, bem como o seu impacto sobre o raciocínio. Kuhn (1993) afirma que as QSC são interessantes no desenvolvimento de atividades argumentativas, pois possibilitam a elaboração de julgamentos e a exposição de opiniões. Driver, Newton e Osborne (2000) veem o argumento como parte da natureza do empreendimento científico, como uma atividade central dos cientistas. Nessa perspectiva apontam a importância da argumentação na educação em Ciências, apresentando uma análise a partir da natureza, função e propósito do argumento dialógico na construção social do conhecimento científico e na interpretação de dados empíricos.

Von Aufschnaiter et al. (2008, p. 1, tradução da autora) investigaram os processos de argumentação de estudantes do ensino médio e desenvolvimento cognitivo em ciência com lições sociocientíficas. A microanálise do discurso realizada pelos autores demonstrou que:

(a) quando os estudantes se engajam na argumentação apresentam suas experiências e conhecimentos anteriores; e (b) a atividade de argumentação permite que os estudantes consolidem o conhecimento existente e elaborem sua compreensão da ciência com níveis relativamente altos de abstração.

Os resultados também sugeriram que os estudantes podem adquirir uma maior qualidade de argumentação, e que o principal indicador da existência ou não de uma alta qualidade do argumento pode ser em função da familiaridade dos estudantes na compreensão do conteúdo da tarefa. Os autores consideraram que para o desenvolvimento da argumentação em sala de aula é necessário identificar a natureza e a extensão dos conhecimentos específicos dos estudantes antes de participarem de atividades que envolvam a argumentação.

Venville e Dawson (2010) conduziram uma pesquisa com estudantes do ensino médio com o objetivo de explorar o impacto da argumentação, do raciocínio informal e da 
compreensão conceitual de genética. Os resultados mostraram que o grupo que desenvolveu argumentação, teve uma melhora significativa na complexidade e na qualidade de seus argumentos, em relação ao grupo controle. Ambos, avançaram significativamente na compreensão da genética.

c) Melhoria na capacidade de avaliar dados e informações científicas

Outra possibilidade de utilização das QSC é na avaliação de dados e informações científicas. Jimenez-Aleixandre, Rodríguez e Duschl, (2000); Kolstø (2001b); Korpan et al. (1997) desenvolveram estudos nessa área.

Jiménez-Aleixandre, Rodríguez e Duschl (2000) analisaram grupos de estudantes discutindo questões relacionadas à genética. Dessas observações surgiram duas categorias denominadas pelos autores como: "operações argumentativas" e "operações epistêmicas". As operações argumentativas caracterizavam-se por apresentarem uma estrutura semelhante ao argumento de Toulmin (2003) com dados, garantias, conclusões, apoios, qualificadores e refutadores. As operações epistêmicas tinham como característica a operação cognitiva usada na elaboração de um argumento como, por exemplo, explicações, analogias, definições, classificações, dentre outras.

Kolstø (2001b) desenvolveu um estudo qualitativo com estudantes noruegueses de 16 anos com o objetivo de caracterizar como os estudantes lidam com a confiabilidade dos dados relacionados a uma QSC sobre as linhas de transmissão de energia e o aumento do risco de leucemia infantil. Foram identificados quatro tipos de estratégias mobilizadas pelos estudantes para decidir em quem e no que confiar: "aceitação da afirmação de conhecimento, avaliação das declarações usando indicadores de confiabilidade, aceitação de pesquisadores ou outras fontes de informação autoritárias, e avaliação de fontes de informação, em termos de interesses, neutralidade ou competência" (p. 881, tradução da autora).

Alguns estudantes utilizaram todas essas estratégias, outros apenas uma ou duas. As avaliações dos estudantes foram baseadas em parte em evidências empíricas, mas principalmente em informações contextuais superficiais. Uma das principais conclusões é que diferentes fontes de informações científicas precisam ser utilizadas no ensino de Ciências.

d) Componente do letramento científico

Uma preocupação que tem sido demonstrada há algumas décadas na área da pesquisa em ensino de Ciências é com a promoção do letramento científico. Esses pesquisadores têm 
reportado a necessidade de inserir QSC como um componente para o letramento científico (ver, por exemplo, DRIVER; NEWTON; OSBORNE, 2000; PEDRETTI; HODSON, 1995; RATCLIFFE; GRACE 2003; SADLER; ZEIDLER; 2009).

Sadler e Zeidler (2009) postularam três premissas, como princípios para o letramento científico, tal como definido pela estrutura das QSC:

\begin{abstract}
(1) o letramento científico deve ser uma meta para todos os estudantes e não só para os que estão destinados a tornarem-se a próxima geração de cientistas, engenheiros e médicos; (2) a educação científica deve proporcionar oportunidades para os estudantes experimentarem a ciência em contextos análogos aos que podem enfrentar em suas experiências vividas fora dos limites da escola; e (3) não tentar separar a ciência de outros elementos que podem ser vistos para além das fronteiras da ciência tradicional (p. 912, tradução da autora).
\end{abstract}

Dirigir a atenção apenas aos formalismos científicos subjacentes a essas questões pode ser mais fácil para os professores. No entanto, as pessoas não vivem suas vidas de acordo com as fronteiras disciplinares e os estudantes devem abordar as QSC nas diversas perspectivas que integram a ciência com outras considerações.

e) Desenvolvimento do raciocínio informal

Pesquisas têm direcionado para estudos sobre o raciocínio informal (ver, por exemplo, KOLSTØ, 2001a; PATRONIS; POTARI; SPILIOTOPOULOU, 1999; WU; TSAI, 2007). Por não apresentarem uma única solução e envolverem considerações de diversas ordens, as QSC se tornam problemas abertos que exigem uma análise crítica e envolvem a consideração de valores, por isso, elas podem ser melhor estudadas por meio do raciocínio informal.

Em uma revisão da literatura, Sadler $(2004 c)$ resume as tendências relacionadas à argumentação como um meio de expressar o raciocínio informal e reitera que as experiências pessoais dos decisores surgiram como uma influência consistente com o raciocínio informal relacionado à QSC. Kuhn (1993) lembra que QSC implicam o uso do raciocínio informal na medida em que são complexas, abertas, e muitas vezes consistem em problemas sem soluções pré-determinadas. O raciocínio informal é compatível com os tipos de dilemas que os estudantes enfrentam no mundo real em que as questões são dinâmicas e podem mudar à medida que novas informações e perspectivas surgem.

Wu e Tsai (2007) a partir de pesquisas descreveram quatro modos de orientação do raciocínio informal, (a) socialmente orientado - considerações baseadas no bem-estar da sociedade e da empatia humana; (b) ecologicamente orientado - considerações ecológicas e 
voltadas a preservação ambiental, (c) economicamente orientado - considerações acerca do desenvolvimento econômico; e (d) científica e tecnologicamente orientado - apoiado em considerações sobre a ciência e a tecnologia.

Os autores concluem o trabalho afirmando que os estudantes elaboraram suas afirmações a partir de várias perspectivas e que a baixa frequência observada na orientação científica e tecnológica pode ser devido à pouca habilidade de relacionar o que eles aprenderam em sala de aula com as QSC.

Em estudo desenvolvido por Kolstø (2006) o foco foi o raciocínio informal dos estudantes na tomada de decisão. Identificou cinco tipos principais de argumentos: o argumento do risco relativo, da precaução, da incerteza, do pequeno risco e o dos prós e contras. Nesse estudo, o autor destaca que as decisões dos adolescentes são principalmente baseadas em valores.

f) Como ferramenta para o desenvolvimento moral

Pesquisas da área de ensino de Ciências têm apresentado evidências de que os processos de tomada de decisões envolvendo QSC são guiados, além do conhecimento científico, por fatores sociais, morais e afetivos (ver, por exemplo, FOWLER; ZEIDLER; SADLER, 2009; MUELLER; ZEIDLER, 2010; SADLER; FOWLER, 2006; SADLER, 2004a e b; WALKER; ZEIDLER, 2007; ZEIDLER; KEEFER, 2003).

Zeidler e Keefer (2003) argumentaram que as QSC podem ser consideradas tanto processos como produtos através de interações sociais e discursivas. Equiparando a educação científica a um "microcosmo da sociedade", as QSC tornam-se um ponto focal para o desenvolvimento e a instrução. Pelas próprias características controversas, dessas questões, a discussão de QSC implicará em alguns momentos em discussões sobre dilemas morais. Os autores indicam que os professores não precisam ser especialistas em desenvolvimento moral para envolverem seus estudantes em um discurso interessante, se referindo ao fato das controvérsias fornecerem contextos reais e constituírem materiais curriculares mais interessantes.

Oulton, Dillon e Grace (2004) se referiram ao fato de que QSC não apresentam uma conclusão única e que as diferentes visões podem ser devido a crenças religiosas, a diferenças culturais e a questões morais. Consideraram que os indivíduos são social e culturalmente construídos e que possuem diferentes valores, sendo assim, apoiaram o fato de que o conhecimento científico sozinho pode ser insuficiente na resolução de determinados conflitos. 
Entretanto, os processos e as teorias científicas podem ajudar as pessoas a tomar decisões em relação às QSC desempenhando um papel na resolução das controvérsias. Esses autores enfatizaram que devemos tornar explícita a natureza das questões controversas na ciência:

1. grupos dentro da sociedade têm diferentes visões acerca dela; 2. grupos diferentes
interpretam a mesma informação de maneiras diferentes; 3. as diferentes
interpretações podem ocorrer, devido à forma como diferentes indivíduos ou grupos
entendem ou "veem" o mundo (ou seja, sua visão de mundo); 4. diferentes visões de
mundo podem ocorrer, por que os indivíduos possuemdiferentes sistemas de valores;
5. questões controversas nemsempre podem ser resolvidas através do recurso à razão,
a lógica ou experiência; e 6. questões controversas podem ser resolvidas quando
houver mais informações dis poníveis. (OULTON; DILLON; GRACE, 2004, p. 412 ,
tradução da autora).

Diante do acima exposto, o conhecimento científico é importante, mas não representa o todo das questões, haja vista que a sua aplicação tem produzido modificações na sociedade que suscitam questionamentos de ordem moral. Além disso, a produção do conhecimento científico está diretamente vinculada às decisões dos cientistas, individualmente ou em grupo, que estão ligadas aos agentes sociais, políticos, econômicos, religiosos, dentre outros. Os rumos da pesquisa científica não são ditados pelo próprio saber científico, e sim por pessoas com interesses diversos, e, frequentemente, conflitantes.

Estudos em história e filosofia da ciência (ver, por exemplo, LACEY, 2008) começaram a revelar, especialmente a partir da segunda metade do século $\mathrm{XX}$, que a elaboração e análise das teorias científicas têm sido influenciadas por ideologias políticas, interesses econômicos, dogmas religiosos, preconceitos metafísicos etc. Isso expõe a ciência, a julgamentos de natureza moral, pois ela não se desenvolve segundo um ideal de racionalis mo científico e, portanto, devem ser avaliadas não apenas do ponto de vista epistemológico, mas também moral.

A literatura científica da área aponta que QSC são permeadas por questões de ordem moral, portanto a sua inserção no ensino de Ciências nos permite trazer situações reais para a tomada de decisão no contexto educacional. Essas questões, geralmente, envolvem uma análise de custo-benefício, do que é certo ou errado, justo ou injusto que interagem com a esfera valorativa dos indivíduos e se apoiam em princípios morais.

A moral é inerente à vida humana, social e cultural, a ciência como um constructo humano, não poderia estar livre de considerações dessa ordem. Nessa mesma linha, segue o filósofo mexicano Vásquez (1989, p. 27): 
a moral só pode surgir - e efetivamente surge - quando o homem supera a sua natureza puramente natural, instintiva, e possui já uma natureza social: isto é, quando já é membro de uma coletividade (gens, várias famílias aparentadas entre si, ou tribo, constituída por vários gens). Como regulamentação do comportamento dos indivíduos entre si e destes com a comunidade, a moral exige necessariamente não só que o homem esteja em relação com os demais, mas também certa consciência - por limitada e imprecisa que seja - dessa relação para que se possa comportar de acordo com as normas ou prescrições que o governam.

A necessidade de integração da moral ao ensino de Ciências é decorrente da inclusão do contexto social e cultural em que a ciência funciona. Tendo como pressuposto que os estudantes têm que ser preparados para lidar com dilemas morais fora da escola, essa deve atuar no desenvolvimento de competências sociais e morais dos estudantes.

Neste trabalho considerou-se a moral que os estudantes vão utilizar na tomada de decisão sobre QSC. Trata-se de uma moral pessoal, do indivíduo, que é constituído a partir de sua interação social e dos elementos históricos que atuam social e individualmente.

\subsection{Um olhar sobre a moral nos estudos nacionais e internacionais de QSC $^{9}$}

Para a elaboração de um panorama geral sobre a moral nas pesquisas da área de ensino de Ciências, foram realizadas buscas sistemáticas em periódicos seguindo os critérios de seleção a seguir: (1) serem da área de ensino ou educação em Ciências e, (2) serem classificados pelo sistema Qualis CAPES entre os estratos A1 e A2. Foram selecionadas e consultadas cinco revistas nacionais e 22 internacionais conforme quadro 1. A partir das análises foram identificadas as principais ideias que constituíram os meios para a identificação de lacunas, elaboração das questões desta pesquisa e utilização como referencial teórico.

Quadro 1 - Periódicos publicados no Brasil e no exterior, selecionados para estudo e sua classificação no sistema Qualis 2014 nas áreas de ensino e educação em Ciências

\begin{tabular}{|l|c|c|}
\multicolumn{1}{|c|}{ Periódico } & $\begin{array}{c}\text { Qualis 2014 } \\
\text { Educação }\end{array}$ & $\begin{array}{c}\text { Qualis 2014 } \\
\text { Ensino }\end{array}$ \\
\hline Ciência \& Educação & A1 & A1 \\
\hline Ciência \& Ensino & A1 & A2 \\
\hline Ensaio: Pesquisa em Educação em Ciências & A2 & A2 \\
\hline Investigações em Ensino de Ciências & A2 \\
\hline Revista Brasileira de Pesquisa em Educação em Ciências & A2 & A1 \\
\hline Cultural Studies of Science Education & A2 & A2 \\
\hline
\end{tabular}

\footnotetext{
${ }^{9} \mathrm{O}$ conteúdo desta seção foi publicado no artigo de nossa autoria (SILVA, S. M. B; SANTOS, W. L. P. O lugar
} da moral no ensino de Ciências. Interacções, n. 31, p. 124-148, 2014). 
Quadro 1 - Periódicos publicados no Brasil e no exterior, selecionados para estudo e sua classificação no sistema Qualis 2014 nas áreas de ensino e educação em Ciências (cont.)

\begin{tabular}{|c|c|c|}
\hline Periódico & $\begin{array}{l}\text { Qualis } 2014 \\
\text { Educação }\end{array}$ & $\begin{array}{c}\text { Qualis } 2014 \\
\text { Ensino }\end{array}$ \\
\hline Educación de las Ciencias & & A 1 \\
\hline Enseñanza de las Ciencias & A 1 & A1 \\
\hline Interciência (Caracas) & & A1 \\
\hline International Journal of Science and Mathematics Education & A 1 & A 1 \\
\hline International Journal of Science Education & A 1 & A 1 \\
\hline Journal of Baltic Science Education & A 2 & A1 \\
\hline Journal of Research in Science Teaching & A 1 & A 1 \\
\hline Journal of Science Education and Technology & A 1 & \\
\hline Natural Science Education & A 1 & A1 \\
\hline Research in Science \& Technological Education & & A 1 \\
\hline Research in Science Education & A 1 & A 1 \\
\hline Revista Eletrónica de Enseñanza de las Ciencias & A 2 & A2 \\
\hline Revista Eletrónica de Investigación en Educación en Ciencias & & A2 \\
\hline Science & & A 2 \\
\hline Science \& Education & A 1 & A1 \\
\hline Science Education & A 1 & \\
\hline Science Education International & A 1 & \\
\hline Science in Context & & A2 \\
\hline Science Studies & A 1 & \\
\hline Science, Technology and Society & & A 2 \\
\hline Studies in Science Education & A 1 & \\
\hline
\end{tabular}

Fonte: Elaboração da autora.

As consultas aos periódicos foram realizadas por meio eletrônico no banco de dados de cada uma das revistas nas publicações compreendidas entre os anos de 1997 a 2013 constituindo, assim, um período de 17 anos de publicações da área. Também foram utilizadas outras formas de pesquisa como a base de dados ERIC (Educational Resources Information Center). O ERIC é uma das bases de dados mais utilizada na pesquisa em educação, uma vez que fornece vasta fonte primária. A fim de realizar as consultas foram utilizados diferentes mecanis mos e o uso de diferentes descritores.

Para a seleção dos artigos nos periódicos nacionais foram utilizados os descritores, "questões sociocientíficas", questões sócio-científicas", “temas controversos", “temas polêmicos", "controvérsias sociocientíficas" e "questões polêmicas". Para as consultas nos 
periódicos internacionais utilizamos "socioscientific issues", "socio-scientific issues", "SSI" e "STS". A identificação dos trabalhos analisados restringiu-se àqueles em que os próprios autores mencionaram explicitamente o termo "questão sociocientífica" e suas variações.

Nos periódicos Enseñanza de las Ciencias, Natural Science Education, Science Studies, Journal of Baltic Science Education, Interciência, Educación de las Ciencias, Revista Eletrónica de Investigación en Educación en Ciencias, Science in Context, Science, Science, Technology and Society, não foram encontrados artigos nas buscas realizadas.

Da primeira etapa de trabalho, foram selecionados 198 artigos que estão relacionados no apêndice A.

Foi realizada uma segunda etapa de seleção com o objetivo de identificar dentre os artigos que apresentaram o descritor "questão sociocientífica" aqueles que possuíam o termo "moral", "moralidade", "ética" e "valores" nos artigos naciona is e "moral", "morality", "ethics" e "value" nos internacionais. O descritor, valores foi considerado nesse estudo, uma vez que esse termo pode remeter a ideia de valores éticos ou morais.

$\mathrm{Na}$ segunda etapa, foram obtidos 112 artigos $(56,6 \%)$ que analisou-se utilizando a estratégia metodológica de Análise Textual Discursiva desenvolvida por Moraes e Galiazzi (2007) a partir da leitura integral dos trabalhos, uma vez que nem sempre os resumos permitiram uma compreensão adequada. Esses dados indicaram que a moral está presente de alguma maneira na maioria dos artigos.

Dos 112 artigos selecionados, $96(85,71 \%)$ apresentavam breves considerações sobre a dimensão moral que envolve tomada de decisão quando são utilizadas QSC, não caracterizando, portanto, um estudo da moralidade em QSC. Assim, apenas 16 artigos (14,29\%) foram considerados no estudo.

Esses dados sugerem que a maioria dos trabalhos desenvolvidos com QSC considera que a moral está presente na tomada de decisão envolvendo QSC, e que esse aspecto tem configurado uma nova abordagem das pesquisas em ensino de Ciências, quando se trata de QSC. Entretanto, apesar de a moral estar sendo apontada como um elemento das QSC, ela não constitui tema central de preocupação desses artigos.

$\mathrm{Na}$ leitura analítica dos 16 artigos que tratam da moralidade em QSC, esses artigos foram classificados em duas categorias excludentes que se encontram na tabela 1 . 
Tabela 1 - Frequência e percentual de ocorrência dos artigos de QSC teóricos e empíricos que tratam da moral

\begin{tabular}{lccc}
\hline Tipo de artigo & Frequência & Ocorrência* $^{(\%)}$ & Ocorrência**(\%) $^{*}$ \\
\hline Teóricos & 1 & 0,89 & 6,25 \\
\hline Empíricos & 15 & 13,39 & 93,75 \\
\hline
\end{tabular}

Fonte: Elaboração da autora.

*Ocorrência em relação aos 112 artigos de QSC que consideram aspectos morais em sua abordagem.

**Ocorrência de artigos com foco específico na moral.

Dos artigos que contemplaram a formação moral, um pequeno número são estudos (Tabela 1) que envolvem uma "descrição e/ou análise dos pressupostos teóricos sobre a formação moral no ensino de Ciências". Tais pesquisas se estruturaram dentro de um quadro teórico que visava dar sustentação aos objetivos da formação moral no ensino de Ciências.

Sobre a análise de pressupostos teóricos relacionados à ética, à moral e os valores só foi encontrado o estudo de RAZERA, J. C. C. e NARDI, R. Ética no ensino de ciências: Responsabilidades e compromis sos com a evolução moral da criança nas discussões de assuntos controvertido. Investigações em Ensino de Ciências, v. 11, n. 1, 2006.

Razera e Nardi (2006) realizaram um levantamento em amostras de publicações sobre o ensino de Ciências, em periódicos científicos da área. Esse estudo revelou que questões sobre ética e desenvolvimento moral têm sido negligenciadas nas pesquisas em educação em Ciências. Utilizando referenciais teóricos que abordam a temática e uma pesquisa sobre o ensino de temas controvertidos, os autores procuraram mostrar que atitudes e implicações para o desenvolvimento moral dos estudantes estariam configuradas nas representações dos professores de Biologia sobre o ensino de evolução dos seres vivos. Diante de questões éticas geradas pelas controvérsias do tema, no plano didático-pedagógico, procuraram identificar se as atitudes dos professores estariam próximas ou distantes da perspectiva ética de favorecimento do desenvolvimento moral dos estudantes.

Os autores concluíram que independente do posicionamento dos professores na defesa de uma ou de outra teoria, não foram detectadas representações que identificassem atitudes de total heteronomia que pudessem causar grandes prejuízos ao desenvolvimento moral dos estudantes. Em geral, os discursos trouxeram elementos sintáticos do campo da ética, como respeito, justiça, liberdade, igualdade e benevolência que, transferidos à prática docente, atuariam em benefício da autonomia moral dos estudantes. Por outro lado, a análise de unidades de significação nos discursos dos professores, também revelou que traços de indesejáveis ideologias são veiculados, mesmo que de forma inconsciente, aos estudantes. 
A maior parte dos trabalhos (Tabela 1) caracterizou-se como estudos empíricos, aqueles cujas fontes de dados foram testes, questionários, entrevistas, dentre outros, e indic ou a prevalência do modelo de abordagem empírica sobre o teórico caracterizando, dessa forma, o modo como a área vem se constituindo.

A seguir são apresentados os estudos empíricos e seus principais elementos.

\subsubsection{Estudos investigativos sobre moralidade em artigos de QSC}

Nas análises realizadas nos 15 artigos empíricos nacionais e internaciona is selecionados em nossa pesquisa bibliográfica (Quadro 2), identificou-se os principais objetivos, o país de origem da pesquisa, a faixa etária dos participantes, o tema de estudo, o tipo de pesquisa (quantitativa, qualitativa ou mista), o referencial teórico sobre moral e os instrumentos utilizados em cada uma dessas obras. Esses dados constituíram fontes essenciais para elaboração de nossas questões, design e referencial analítico de pesquisa, além de estabelecer um panorama acerca da área de pesquisa.

Quadro 2- Artigos empíricos sobre moral em artigos de QSC

\begin{tabular}{|c|c|}
\hline Título & Autores \\
\hline $\begin{array}{l}\text { A pedagogical model for ethical inquiry into socioscientific issues in } \\
\text { science. Research in Science Teaching, v. } 43, \text { n.1, } 2013 \text {. }\end{array}$ & Saunders, K. J.; Rennie, L. J. \\
\hline $\begin{array}{l}\text { Bioética e ensino de ciências: O tratamento de temas controversos - } \\
\text { dificuldades apresentadas por futuros professores de Ciências e Biologia. } \\
\text { Ciência \& Educação, v. } 19 \text {, n. } 2 \text {, } 2013 \text {. }\end{array}$ & Silva, P. F.; Krasilchik, M. \\
\hline $\begin{array}{l}\text { Developing character and values for global citizens: analysis of pre-service } \\
\text { science teachers' moral reasoning on socioscientific is sues. International } \\
\text { Journal of Science Education, v. } 34 \text {, n. 6, 2012a. }\end{array}$ & $\begin{array}{l}\text { Lee, H.; Chang, H.; Choi, K.; } \\
\text { Kim, S.; Zeidler, D. L. }\end{array}$ \\
\hline $\begin{array}{l}\text { Is judgement of biotechnological ethical aspects related to high school } \\
\text { students'knowledge? International Journal of Science Education, v. 34, } \\
\text { n. 8, 2012. }\end{array}$ & $\begin{array}{l}\text { Črne-Hladnik, H.; Hladnik, A.; } \\
\text { Javornik, B.; Košmelj, K.; } \\
\text { Peklaj, C. }\end{array}$ \\
\hline $\begin{array}{l}\text { Co-opting Science: A preliminary study of how students invoke science in } \\
\text { value-laden discussions. International Journal of Science Education, v. } \\
34, \text { n. } 2,2012 \text {. }\end{array}$ & Nielsen, J. A. \\
\hline $\begin{array}{l}\text { Socioscientific issues as a vehicle for promoting character and values for } \\
\text { global citizens. International Journal of Science Education, I First, } \\
\text { 2012b. }\end{array}$ & $\begin{array}{l}\text { Lee, H.; Yoo, J.; Choi, K.; Kim, } \\
\text { S.; Krajcik, J; Herman, B. C.; } \\
\text { Zeidler, D. L. }\end{array}$ \\
\hline $\begin{array}{l}\text { Climate change and morality: Students' perspectives on the individual and } \\
\text { society. International Journal of Science Education, v. 33, v. 8, } 2011 .\end{array}$ & Sternäng, L.; Lundholm, C. \\
\hline $\begin{array}{l}\text { Raciocínio moral na tomada de decisões em relação a questões } \\
\text { sociocientíficas: O exemplo do melhoramento genético humano. Ciência } \\
\text { \& Educação, v. } 16, \text { n. } 2,2010 \text {. }\end{array}$ & $\begin{array}{l}\text { Guimarães, M. A.; Carvalho, W. } \\
\text { L. P.; Oliveira, M. S. }\end{array}$ \\
\hline $\begin{array}{l}\text { Teaching about ethics through socioscientific issues in physics and } \\
\text { chemistry: Teacher candidates' beliefs. Journal of Research in Science } \\
\text { Teaching, v. } 47 \text {, n. } 4,2010 \text {. }\end{array}$ & Barrett, S. E.; Nieswandt, M. \\
\hline
\end{tabular}


Quadro 2- Artigos empíricos sobre moral em artigos de QSC (cont.)

\begin{tabular}{|l|l|}
\hline \multicolumn{1}{|c|}{ Título } & \multicolumn{1}{|c|}{ Autores } \\
\hline $\begin{array}{l}\text { Moral sensitivity in the context of socioscientific issues in high school } \\
\text { science students. International Journal of Science Education, v. 31, n. 2, } \\
2009 .\end{array}$ & $\begin{array}{l}\text { Fowler, S. R.; Zeidler, D. L.; } \\
\text { Sadler, T. D. }\end{array}$ \\
\hline $\begin{array}{l}\text { Ethics or morals: Understanding students' values related to genetic tests on } \\
\text { humans. Science \& Education, v. 18, n. 10, 2009. }\end{array}$ & Lindahl, M. G. \\
\hline $\begin{array}{l}\text { Socioscientific argumentation: The effects of content knowledge and } \\
\text { morality. International Journal of Science Education, v. 28, n. 12, 2006. }\end{array}$ & Sadler, T. D.; Donnelly, L. A. \\
\hline $\begin{array}{l}\text { Socioscience and ethics in science classrooms: Teacher perspectives and } \\
\text { strategies. Journal of Research in Science Teaching, v. 43, n. 4, 2006. }\end{array}$ & $\begin{array}{l}\text { Sadler, T. D.; Amirshokoohi, } \\
\text { K. M. }\end{array}$ \\
\hline $\begin{array}{l}\text { The morality of socioscientific is sues: Construal and resolution of genetic } \\
\text { engineering dilemmas. Science Education, v. 88, n. 1, 2004. }\end{array}$ & Sadler, T. D.; Zeidler, D. L. \\
\hline $\begin{array}{l}\text { The science and values that young people draw upon to make decisions } \\
\text { about biological conservation is } \\
\text { Education, v. 24, n. 11, 2002. }\end{array}$ & Grace, M. M.; Ratcliffe, M. \\
\hline
\end{tabular}

Fonte: Elaboração da autora.

Importante destacar que, das 15 pesquisas empíricas, nove foram realizadas com estudantes, sendo seis delas em ambiente de sala de aula (ČRNE-HLADNIK et al., 2012; FOWLER et al., 2009; GRACE; RATCLIFFE, 2006; NIELSEN, 2012; SADLER; DONNELLY, 2006; STERNÄNG; LUNDHOLM, 2011) e uma com professores (LEE et al. 2012a).

Quanto ao nível de escolaridade, 11 estudos $(73,33 \%)$ utilizaram dados provenientes de grupos de estudantes de EM e universitários (ČRNE-HLADNIK, et al., 2012); estudantes de 14, 15 e 17 anos (LEE et al., 2012a); 14 anos (STERNÄNG; LUNDHOLM, 2011); 16 a 18 anos (FOWLER et al., 2009); 15 a 18 anos (SADLER; DONNELLY, 2006); 15 e 16 anos (GRACE; RATCLIFFE, 2002); 15 a 17 anos (GUIMARÃES et al., 2010); estudantes de ensino médio (NIELSEN, 2012); 17 anos (LINDAHL, 2009) e estudantes universitários (acima de 18 anos) (SADLER; ZEIDLER, 2004; SILVA; KRASILCHIK, 2013). O restante dos trabalhos, quatro $(26,67 \%)$ foi realizado com professores.

Cabe ressaltar, ainda, que, a indicação do nível de escolaridade/faixa etária não indica que todas essas pesquisas tenham sido realizadas em um contexto de sala de aula. Depreendese, portanto, a partir desses dados, que a maioria dos estudos foi realizado com estudantes abrangendo diversas idades a partir dos 14 anos, sendo poucos os que se dedicaram aos professores e a estudantes universitários. 
A literatura internacional tem fornecido evidências empíricas sobre o papel de considerações morais em QSC e a tomada de decisão por indivíduos de diferentes idades (BELL; LEDERMAN, 2003; SADLER; DONNELLY, 2006; ZEIDLER et al., 2002).

Os estudos realizados apresentaram diferentes nacionalidades com maior número de contribuições dos Estados Unidos (4), seguidas do Brasil (2), Coreia do Sul (2), Nova Zelândia (1), República da Eslovênia (1), Japão (1), Inglaterra (1), Dinamarca (1), Suécia (1) e Canadá (1). Os dados sugerem que além de poucos esses estudos são esparsos, com poucas representações em diferentes países.

Em relação aos temas utilizados nos estudos, a maioria aborda aqueles relacionados à biologia, 13 trabalhos $(86,67 \%)$ tais como: projeto genoma humano (SAUNDERS; RENNIE, 2013); alterações climáticas, células tronco embrionárias (LEE et al., 2012a) nesse estudo, também utilizaram temas interdisciplinares que envolvem o ensino de química e física como: armas nucleares e geração de energia; aplicações biotecnológicas (ČRNE-HLADNIK et al., 2012); modificação genética (LEE et al., 2012b); mudança climática (STERNÄNG; LUNDHOLM, 2011); aplicações biotecnológicas (FOWLER et al., 2009); terapia gênica e clonagem (SADLER; DONNELLY, 2006); conservação biológica (GRACE; RATCLIFFE, 2002); terapia gênica e clonagem (SADLER; ZEIDLER, 2004); terapia gênica (NIELSEN, 2012); testes genéticos (LINDAHL, 2009); questões ligadas ao meio ambiente, a novas biotecnologias e a relação entre ciência e sociedade (SILVA; KRASILCHIK, 2013); melhoramento genético (GUIMARÃES et al., 2010) e dois trabalhos (12,5\%) sem tema específico.

É possível perceber que a maioria dos temas das pesquisas são controversos, que se caracterizam por envolver conteúdos científicos, mas também, questões de diversas ordens, dentre elas, moral (ou ética) e valores. A maioria dos estudos têm sido desenvolvidos sobre temas da Biologia, por exemplo, os que envolvem a biotecnologia como: testes genéticos, clonagem, células-tronco, terapia gênica e que levantam questionamentos de ordem moral, uma vez que envolvem considerações sobre a vida, a sobrevivência etc.

Nas investigações que levantaram as concepções das pessoas sobre os aspectos morais, os instrumentos de coleta de dados mais utilizados foram entrevistas e/ou questionários com nove trabalhos (60\%), seguidos de atividades em vídeo e áudio gravados em três trabalhos (20\%), pré e pós-teste em dois trabalhos $(13,33 \%)$ e de um trabalho $(6,66 \%)$ com pré-teste para verificação do nível de conhecimento e aplicação de teste para verificação do desenvolvimento moral Defining Issue Test (DIT). No que se refere aos instrumentos, observou-se uma 
predominância do número de entrevistas e questionários na escolha dos pesquisadores, que também foram os principais instrumentos utilizados nas pesquisas qualitativas.

Quanto ao tipo de pesquisa 10 trabalhos $(66,66 \%)$ apresentaram uma abordagem qualitativa, enquanto outros quatro $(26,66 \%)$ apresentaram uma abordagem mista, ou seja, aplicaram aos dados algum tipo de tratamento matemático procurando justificar suas análises, e um trabalho $(6,66 \%)$ com abordagem quantitativa. Esses dados indicam que a maior parte dos estudos tem privilegiado a análise qualitativa, o que pode ser devido à própria natureza do tema de estudo.

Foram utilizados referenciais teóricos sobre moral tanto da psicologia quanto da filosofia (Quadro 3), sendo os da psicologia os mais comumente citados, ressaltando a relevância psicológica da dimensão estruturadora da moralidade, como a sua inter-relação com temas de importância em nível social.

Os estudos sobre moral têm atraído a atenção de diversos campos de estudo como a filosofia, sociologia e psicologia. No levantamento realizado, os pesquisadores da psicologia Reiss, Rest, Gilligan, Kohlberg e Noddings foram os mais citados. Nos estudos sobre ética ou moral em QSC, é possível observar que essas são exploradas por diversos ângulos e a partir de diversos pressupostos teóricos; entretanto, cada uma das diferentes perspectivas teóricas que têm abordado o tema trouxe contribuições importantes para o seu estudo.

Quadro 3-Referenciais teóricos dos artigos empíricos sobre moralidade por autor

\begin{tabular}{|l|l|}
\hline \multicolumn{1}{|c|}{ Autores } & \multicolumn{1}{|c|}{ Principais referenciais teóricos citados } \\
\hline $\begin{array}{l}\text { Črne-Hladnik et al., 2012; Saunders e Rennie, 2013; } \\
\text { Sternäng e Lundholm, 2011. }\end{array}$ & Reiss (2003, 2006 e 2008) \\
\hline $\begin{array}{l}\text { Fowler et al., 2009; Lindahl, 2009; Sadler e Donnelly, } \\
\text { 2006. }\end{array}$ & $\begin{array}{l}\text { Rest (1979, 1986 e 1999); Rest, Cooper, Coder, } \\
\text { Masanz e Anderson (1974); Rest, Narvaez e Bebeau } \\
\text { (2000); Rest, Narvaez, Bebeau e Thoma (1999). }\end{array}$ \\
\hline $\begin{array}{l}\text { Lee et al., 2012a; Lee et al., 2012b; Lindahl, 2009; } \\
\text { Sadler e Zeidler, 2004; }\end{array}$ & Gilligan (1982, 1987) \\
\hline Lindahl, 2009; Silva e Krasilchik, 2013 & Kohlberg (1969, 1981, 1984) \\
\hline $\begin{array}{l}\text { Barrett et al., 2010; Lee et al., 2012a; Sadler e Zeidler, } \\
\text { 2004 }\end{array}$ & Noddings (1984, 1995) \\
\hline Črne-Hladnik et al., 2012 & Mepham (2005) \\
\hline Sternäng e Lundholm, 2011 & $\begin{array}{l}\text { Carpendale e Krebs (1992); Harré (1984); Levine } \\
\text { (1979). }\end{array}$ \\
\hline Lee et al., 2012a e 2012b & Ruiz e Vallejos (1999) \\
\hline Lee et al., 2012a & Stern, Dietz e Kalof (1993) \\
\hline Barrett et al., 2010 & Freire (1998); Derrida (1995); Allchin (1999) \\
\hline Guimarães, Carvalho e Oliveira, 2010 & Habermas (2004) \\
\hline
\end{tabular}


Quadro 3-Referenciais teóricos dos artigos empíricos sobre moralidade por autor

\begin{tabular}{|c|c|}
\hline Autores & Principais referenciais teóricos citados \\
\hline Silva e Krasilchik, 2013 & $\begin{array}{l}\text { Habermas (2001); Kant (1996); Piaget }(1994,1996) \text {; } \\
\text { Rousseau (2004). }\end{array}$ \\
\hline Grace e Ratcliffe, 2002 & $\begin{array}{l}\text { Callicott (1997); Greaves et al. (1993); Spellerberg } \\
\text { (1992). }\end{array}$ \\
\hline Lindahl, 2009 & $\begin{array}{l}\text { Batson et al. (1997); Bauman (1994); Farver e } \\
\text { Branstetter (1994); Giddens (1990); Krebs et al. } \\
\text { (1991); Nichols (2004); Sugarman (2005); Stevenson } \\
\text { (1944); Strasberg (2005); Williams (1973 e 1985). }\end{array}$ \\
\hline Nielsen, 2012 & Dewey (1981); Hare (1952); Nowell-Smith (1954) \\
\hline Fowler et al., 2009 & $\begin{array}{l}\text { Bebeau, Rest e Yamoor (1985); Belenky, Clinchy, } \\
\text { Goldberg e Tarule (1986); Berkowitz, (1997); } \\
\text { Eisenberg (2000). }\end{array}$ \\
\hline Sadler e Zeidler, 2004 & $\begin{array}{l}\text { Beuchamp (1982); Blair (1997); De Marco (1996); } \\
\text { Ford e Lowery (1986); Killen, Leviton e Cahill } \\
\text { (1991); Moore (1991); Nucci (2001); Nucci e Turiel } \\
\text { (1993); Tisak (1995); Tisak e Turiel (1988); Tronto } \\
\text { (1987); Turiel (1983); Turiel e Smetana (1984); } \\
\text { Smetana (1989); Wainryb (1991). }\end{array}$ \\
\hline
\end{tabular}

Fonte: elaboração da autora.

Dos 15 estudos empíricos, foi possível a identificação de quatro temas que são apresentados na tabela 2 .

Tabela 2 - Frequência e percentual de artigos de QSC empíricos sobre aspectos morais por tema de estudo

\begin{tabular}{lcc}
\hline \multicolumn{1}{c}{ Perspectivas investigativas } & $\mathbf{N}^{\mathbf{0}}$ de artigos & Ocorrência* (\%) \\
\hline Aspectos morais de estudantes e professores & 10 & 66,7 \\
\hline Concepções de professores sobre o ensino de ética & 2 & 13,2 \\
\hline Propostas pedagógicas & 2 & 13,2 \\
\hline Formação de professores & 1 & 6,67 \\
\hline
\end{tabular}

Fonte: Elaboração da autora.

*Em relação aos 15 estudos empíricos.

A partir da análise dos dados da tabela 2, conclui-se que a maior parte dos estudos buscou compreender o fenômeno da moralidade em estudantes. Poucos são os trabalhos voltados a concepções de professores sobre o ensino de ética, e escassos os que envolvem propostas pedagógicas e formação de professores, abrindo uma lacuna em relação a essas questões.

O quadro 4 relaciona os artigos com seus respectivos temas de estudo. 
Quadro 4-Classificação das pesquisas segundo o tema de estudo

\begin{tabular}{|c|c|}
\hline Título & Temas de estudo \\
\hline $\begin{array}{l}\text { Developing character and values for global citizens: Analysis of pre-service } \\
\text { science teachers' moral reasoning on socioscientific issues International } \\
\text { Journal of Science Education, v. } 34 \text {, n. } 6,2012 \text { a. }\end{array}$ & \multirow{10}{*}{$\begin{array}{l}\text { Aspectos morais de estudantes e } \\
\text { professores }\end{array}$} \\
\hline $\begin{array}{l}\text { Is judgment of biotechnological ethical aspects related to high school } \\
\text { students'knowledge? International Journal of Science Education, v. } 34 \text {, } \\
\text { n. 8, 2012. }\end{array}$ & \\
\hline $\begin{array}{l}\text { Raciocínio moral na tomada de decisões em relação a questões } \\
\text { sociocientíficas: O exemplo do melhoramento genético humano. Ciência \& } \\
\text { Educação, v. } 16 \text {, n. } 2,2010 \text {. }\end{array}$ & \\
\hline $\begin{array}{l}\text { The science and values that young people draw upon to make decisions } \\
\text { about biological conservation issues. International Journal of Science } \\
\text { Education, v. } 24 \text {, n. } 11,2002 \text {. }\end{array}$ & \\
\hline $\begin{array}{l}\text { Climate change and morality: Students' perspectives on the individual and } \\
\text { society. International Journal of Science Education, v. 33, n. 8, } 2011 \text {. }\end{array}$ & \\
\hline $\begin{array}{l}\text { Moral sensitivity in the context of socioscientific issues in high school } \\
\text { science students. International Journal of Science Education, v. 31, n. } 2 \text {, } \\
2009 \text {. }\end{array}$ & \\
\hline $\begin{array}{l}\text { Socioscientific argumentation: The effects of content knowledge and } \\
\text { morality. International Journal of Science Education, v. 28, n. 12, } 2006 .\end{array}$ & \\
\hline $\begin{array}{l}\text { The morality of socioscientific issues: Construal and resolution of genetic } \\
\text { engineering dilemmas. Science Education, v. } 88, \text { n. 1, } 2004 \text {. }\end{array}$ & \\
\hline $\begin{array}{l}\text { Ethics or morals: Understanding students' values related to genetic tests on } \\
\text { humans. Science \& Education, v. 18, n. 10, } 2009 .\end{array}$ & \\
\hline $\begin{array}{l}\text { Co-opting science: A preliminary study of how students invoke science in } \\
\text { value-laden discussions. International Journal of Science Education, v. } \\
34, \text { n. } 2,2012 \text {. }\end{array}$ & \\
\hline $\begin{array}{l}\text { Teaching about ethics through socioscientific issues in physics and } \\
\text { chemistry: Teacher candidates' beliefs. Journal of Research in Science } \\
\text { Teaching, v. } 47, \text { n. } 4,2010 \text {. }\end{array}$ & \multirow{2}{*}{$\begin{array}{l}\text { Concepções de professores } \\
\text { sobre o ensino de ética }\end{array}$} \\
\hline $\begin{array}{l}\text { Socioscience and ethics in science classrooms: Teacher perspectives and } \\
\text { strategies. Journal of Research in Science Teaching, v. 43, n. 4, } 2006 .\end{array}$ & \\
\hline $\begin{array}{l}\text { A pedagogical model for ethical inquiry into socioscientific issues in } \\
\text { science. Research in Science Teaching, v. 43, n. 1, } 2013 \text {. }\end{array}$ & \multirow[b]{2}{*}{ Proposta pedagógica } \\
\hline $\begin{array}{l}\text { Socioscientific issues as a vehicle for promoting character and values for } \\
\text { global citizens. International Journal of Science Education, I First, } \\
\text { 2012b. }\end{array}$ & \\
\hline $\begin{array}{l}\text { Bioética e ensino de Ciências: O tratamento de temas controversos - } \\
\text { dificuldades apresentadas por futuros professores de Ciências e Biologia. } \\
\text { Ciência \& Educação, v. } 19 \text {, n. } 2,2013 \text {. }\end{array}$ & Formação de professores \\
\hline
\end{tabular}

Fonte: elaboração da autora.

A seguir apresentamos uma breve descrição por categoria dos estudos empíricos. 
a) Aspectos morais de estudantes e professores

Os estudos de Črne-Hladnik et al. (2012), Sternäng e Lundholm (2011), Fowler et al. (2009), Sadler e Donnelly (2006), Grace e Ratcliffe (2002), Sadler e Zeidler (2004), Lindahl (2009) e Guimarães et al. (2010), de forma geral, buscaram conhecer como estudantes de diferentes níveis de escolaridade manifestam valores morais na tomada de decisão envolve ndo QSC.

Em geral, os pesquisadores concluíram que na tomada de decisão os estudantes são guiados por fatores sociais, morais e afetivos que podem variar de acordo com o contexto e com o referencial de análise, se é o próprio indivíduo ou outra pessoa. Nas pesquisas que relacionaram o conhecimento científico, esse tem representado um papel secundário.

Segue uma breve apresentação de cada um dos artigos pertencentes a essa categoria.

Developing Character and Values for Global Citizens: Analysis of Pre-Service Science Teachers' Moral Reasoning on Socioscientific Issues

No estudo desenvolvido por Lee et al. (2012a), partindo do pressuposto que caráter e valores são forças motrizes essenciais que servem como guias gerais ou pontos de referência para os indivíduos apoiarem a tomada de decisão envolvendo QSC, os pesquisadores investigaram como professores da Coréia do Sul manifestam caráter e valores de cidadãos globais quando confrontados como uma QSC global.

Segundo os autores, caráter e valores desempenham um papel essencial de mediação como forças que levam os indivíduos a se conectarem pessoalmente com questões globais e, além disso, servem como predisposições na tomada de decisão.

Lee et al. (2012a) identificaram quatro grandes tendências. A primeira tendência foi a presença de visões de mundo ecológica, responsabilidade sociocientífica e compaixão social e moral. No entanto, os professores não aplicaram princípios morais consistentes em relação às questões. Mesmo que alguns fossem compassivos para com os países subdesenvolvidos com respeito à questão da mudança climática, eles não revelaram compaixão para com as necessidades de outros países em relação à geração de energia nuclear. Da mesma forma, alguns professores defenderam mais responsabilidade para a mudança climática, mas se sentiram menos responsáveis quando se tratava de geração e venda de tecnologia de energia nuclear para países situados em zonas sísmicas.

A segunda tendência revelou que perspectivas sobre as questões mundiais eram uma ocorrência rara. Os pontos de vista dos sujeitos envolvidos na pesquisa tendiam a limitar-se a 
perspectivas pessoais e sociais locais. Por exemplo, os professores priorizavam os lucros de seus conterrâneos e de seu próprio país, em detrimento do bem-estar global.

A terceira tendência indicou que os professores não se perceberam como agentes morais capazes de resolver problemas ativamente. Por exemplo, em relação à questão dos direitos de emissão de carbono, concordaram que os países avançados são os principais responsáveis pelo aquecimento global e, por isso, existe a necessidade de resolver a injustiça entre as nações. Eles exibiram compaixão social e moral para com os países subdesenvolvidos, que são afetados pela mudança climática como resultado da ação de nações tecnologicamente mais avançadas. No entanto, quanto à atribuição de culpa aos países avançados, eles pareciam desconhecer o fato de que eles, como cidadãos de um país mais desenvolvido, também são responsáveis pelas políticas que afetam o aquecimento global do seu próprio país.

Por último, a quarta tendência, demonstrou que o raciocínio emotivo foi usado nas discussões. No entanto, esse estudo também mostrou que os sujeitos tendem a apresentar um alto grau de confiança na ciência e tecnologia e que muitos não mudaram seus pensamentos iniciais sobre as questões durante as discussões, o que sugere que os professores não aplicaram princípios morais consistentes na análise dos problemas e perspectivas globais, demonstrando uma tendência de análise das questões com emoção e simpatia.

\section{Is Judgment of Biotechnological Ethical Aspects Related to High School Students' Knowledge?}

Parte das evidências observadas na área das QSC sugere que os processos de tomada de decisão envolvendo essas questões são guiados por fatores sociomorais e pelo domínio afetivo. O conhecimento de conteúdo científico parece contribuir minimamente para as decisões reais que os indivíduos tomam em contextos sociocientíficos (BELL; LEDERMAN, 2003; SADLER; FOWLER, 2006; WALKER; ZEIDLER, 2007).

Črne-Hladnik et al. (2012) investigaram a percepção de estudantes de 17 anos sobre a utilidade, a aceitação moral e a percepção de risco de aplicações biotecnológicas. Para essa investigação foram criadas várias categorias, que pertenciam a um dos três padrões de raciocínio moral:

(1) racionalista é baseado nas consequências das aplicações biotecnológicas (raciocínio teleológico) ou moral deontológica;

(2) emotivo é caracterizado pelo fato dos estudantes não apoiarem seus julgamentos sobre uma deliberação racional de consequências ou princípios, mas em emoções; e

(3) intuitivo, nesse tipo de raciocínio os estudantes respondem intuitivamente (instintivamente), assim as suas decisões não são decorrentes do resultado de uma análise de consequências, princípios ou emoções. (ČRNE-HLADNIK et al., 2012, p. 1284, tradução da autora). 
Os pesquisadores encontraram diferenças de gênero em relação às atitudes acerca da percepção de risco das aplicações biotecnológicas. Identificou-se padrões de raciocínio moral racionalista, emotivo intuitivo. Entretanto, os estudantes com menos conhecimento em genética apresentaram o padrão de raciocínio intuitivo com mais frequência do que os seus pares com melhor pré-conhecimento.

\section{Climate Change and Morality: Students' Perspectives on the Individual and Society}

No seu estudo sobre "Mudança climática e moralidade: perspectivas individuais e sociais dos estudantes", Sternäng e Lundholm (2011) apontaram que há um interesse crescente em abordar aspectos morais na pesquisa com QSC. Eles investigaram as interpretações dos estudantes sobre as mudanças climáticas a partir de uma perspectiva moral, analisando se a exposição regular a um currículo de Ciências com QSC altera a propensão de um indivíduo para identificar e considerar os aspectos morais dessas questões a nível individual.

Os resultados mostraram que os estudantes analisam as soluções para mitigar as mudanças climáticas em relação a duas posições diferentes, tomando como referência o indivíduo, onde o indivíduo é ou "eu" ou "outro". Indivíduos como "eu" indicam que os estudantes tendem a priorizar os seus interesses pessoais e benefícios, ao invés de considerar os efeitos ambientais globais.

Os autores concluíram que as diferentes noções de indivíduo se tornam cruciais para os pontos de vista e considerações dos estudantes em relação ao meio ambiente e a sociedade, e que mudam de acordo com os diferentes contextos. Do ponto de vista moral os estudantes pareceram bastante inconscientes de suas considerações para com o ambiente e a sociedade.

\section{Moral Sensitivity in the Context of Socioscientific Issues in High School Science Students}

Fowler, Zeidler e Sadler (2009) utilizando um Ensaio de Sensibilidade Ética em Ciência (TESS) e diferentes cenários envolvendo QSC, analisaram se um currículo de Ciências com QSC interfere na sensibilidade moral dos estudantes.

Para tanto, utilizaram um modelo de quatro componentes.

- Sensibilidade moral: capacidade de reconhecer quando uma situação contém um aspecto moral. Quando confrontados com uma QSC, uma pessoa com sensibilidade moral está ciente de como possíveis resoluções da situação tem o potencial de afetar os outros de uma forma negativa. Assim, uma pessoa com sensibilidade moral está em sintonia com os sentimentos e reações dos outros. 
Estando ciente de cursos alternativos de ação, são capazes de antecipar as consequências de cada um e de examinar os aspectos de uma situação.

- Razão moral: análise usada para determinar qual curso de ação é moralmente desejável em uma determinada situação e a capacidade de defendê-la através do uso de habilidades de pensamento crítico. Ela exige a identificação de cursos de ação e a capacidade de apresentaruma justificação.

- Compromisso moral: o reconhecimento de uma situação moral e a análise por meio do raciocínio moral não garante que uma ação moral irá ocorrer. Conhecer a cois a certa a fazer e realmente fazê-la não é a mesma coisa. Assim, a prioridade das preocupações morais é o terceiro componente do desenvolvimento moral, o compromisso moral. Isto requer primeiro o reconhecimento de que as questões pessoais não são sempre compatíveis com a ação moral, seguida de uma vontade de escolher o que ele ou ela tenha considerado o curso mais moral de uma ação.

- Coragem moral: está intimamente ligada à prioridade com o compromisso moral. Uma pessoa pode reconhecer uma situação moral e estar dis posta a seguir o curso de uma ação moral, mas, às vezes, a pessoa pode ceder a pressão dos outros para não fazê-la. Embora, disposta a seguir o curso de uma ação moral (ou seja, ter o compromisso moral), uma pessoa também precisa de coragem moral, a fim de seguir adiante com sua decisão, conforme os autores. (FOWLER; ZEIDLER; SADLER, 2009, p. 281-282, tradução da autora).

Se o raciocínio moral é usado para determinar um curso de ação, em seguida, pode-se argumentar que é preciso em primeiro lugar a capacidade de reconhecer os aspectos morais da situação. No entanto, ser capaz de fazê-lo não determina necessariamente que uma pessoa fará em qualquer situação. A sensibilidade moral é uma condição necessária, mas não suficiente para o raciocínio moral e uma ação moral.

Nessa pesquisa, os autores utilizaram quatro turmas de estudantes de nível médio, durante o período de um ano, onde duas constituíram o grupo controle e duas o grupo tratamento, entretanto apenas com o grupo tratamento foi desenvolvido um currículo mais orientado à inserção de QSC. O teste para avaliação da sensibilidade moral (TESS plus) foi aplicado no início e no final do ano.

Os critérios utilizados na definição dos diferentes graus de sensibilidade moral foram:

- grau 0 - não há indicação de considerações éticas/morais;

- grau 1 - caracteriza-se pelo reconhecimento de alguns riscos éticos e morais, os quais poderiam ser um caminho para considerações de nível superior;

- grau 2 - apresentam considerações de riscos éticos e morais; e 
- grau 3 - fortes considerações de consequências éticas e morais incluindo o papel de pessoas que tomam decisões que influenciam a aceitação de riscos.

A partir desse estudo os autores apontam que, embora ambos os grupos tenham mostrado um aumento na sensibilidade moral para o cenário denominado modificação genética, o grupo tratamento teve um ganho maior do que o grupo controle, porém não houve diferenças significativas em relação ao cenário denominado clonagem reprodutiva. Portanto, a sensibilidade moral dos estudantes diferiu conforme o cenário apresentado e os dados obtidos foram consistentes com pesquisas anteriores que apontaram que indivíduos tendem a raciocinar em altos níveis morais em situações que envolvem suas emoções, sensibilidade ou crenças afetivas.

\section{A Socioscientific Argumentation: The Effects of Content Knowledge and Morality}

Sadler e Donnelly (2006) em uma investigação com estudantes procuraram verificar se o conhecimento do conteúdo e o raciocínio moral contribuem para a qualidade da argumentação com QSC.

Para a avaliação do conhecimento do conteúdo de genética, foi aplicado um teste de Conhecimento de Genética Básica (TBGC). A análise do raciocínio moral foi realizada com a utilização do Defining Issues Test (DIT). Esse teste pressupõe que os indivíduos progridem através de estágios de desenvolvimento ou "esquemas" que guiam o raciocínio e a tomada de decisão em contextos morais. Os esquemas mais avançados são baseados em princípios morais generalizáveis, como a justiça, a beneficência e a não maleficência.

O DIT é composto por seis dilemas morais. Devido a limitações logísticas de aplicação do teste o número de dilemas foi reduzido para quatro. Também foi utilizado um cenário modificado visando à reflexão sobre temas mais contemporâneos. A qualidade da argumentação foi demonstrada em entrevistas. As respostas dos participantes de cada um dos cenários foram avaliadas com base em três critérios: posição e lógica; múltipla perspectiva de tomada de decisão e refutação.

Os resultados do estudo não revelaram nenhuma relação significativa entre conhecimentos de conteúdo e habilidades de argumentação. Em relação ao raciocínio moral, as análises qualitativas sugerem que os estudantes do EM envolvidos em discussões sobre engenharia genética frequentemente as interpretam com considerações de ordem moral. No entanto, os resultados quantitativos não complementaram esse achado. Pontuações no DIT não foram significativamente correlacionadas com a qualidade da argumentação. 
Os autores apontaram que é provável que o DIT, por constituir uma perspectiva abstrata sobre a moralidade não tenha sido suficiente para descrever o tipo de moralidade pessoal invocada pelos cenários apresentados nesse estudo. Assim, as correlações entre argumentação e o DIT pareceram subestimar possíveis relações entre argumentação e considerações morais.

The science and values that young people draw upon to make decisions about biological conservation issues

Considerando que especialistas nem sempre são capazes de chegar a um acordo sobre abordagens de conservação biológica, especialmente quando a ciência é fortemente impulsionada pela política, Grace e Ratcliffe (2002) buscaram conhecer que conceitos e valores os estudantes usam quando discutem questões de conservação biológica. Os autores tomaram como base os conceitos que os especialistas e professores consideram essenciais na questão da conservação biológica, e quais valores os professores acreditam que os estudantes considerariam na prática.

Grace e Ratcliffe (2002) se apoiaram em dois tipos básicos de valor: antropocêntrico, ou seja, úteis de alguma forma para os seres humanos; e biocêntrico, ou seja, inerentemente valioso como um fim em si, conforme o quadro 5.

Quadro 5 - Valores usados na tomada de decisão sobre conservação biológica

\begin{tabular}{|c|l|}
\hline Valores & \multicolumn{1}{|c|}{ Exemplos } \\
\hline Biocêntrico (Intrínseco/Ético) & $\bullet$ Direito de viver \\
& $\bullet$ Antropomorfismo \\
\hline & $\bullet$ Estética/Fruição \\
& $\bullet$ Econômica/Custo \\
Antropocêntrico (Utilitário): que pode trazer alguns benefícios para os & $\bullet$ Efetividade \\
seres humanos & $\bullet$ Altruís mo/Futuras gerações \\
& $\bullet$ Segurança \\
& $\bullet$ Informação/Pesquisa \\
& científica \\
\hline
\end{tabular}

Fonte: Grace e Ratcliffe (2002, p. 1163, tradução da autora).

Os autores concluíram que, embora, os estudantes tenham feito uso de vários conceitos biológicos importantes, foi mais perceptível a incorporação de valores nas discussões, sendo que os mesmos tenderam a expressar mais os valores antropocêntricos como: estética/prazer, custo/benefício, altruísmo/geração futura e segurança. Para Grace e Ratcliffe (2002, p.1167, tradução da autora) "a concorrência entre organismos é um conceito científico; competição 
entre os animais e os seres humanos é uma questão de valores, dependentes do ponto de vista biocêntrico-antropocêntrico".

Um grande número de conceitos biológicos foi considerado essencial por especialis tas, mas pareceu improvável que todos eles pudessem ser integrados com sucesso na decisão prática, principalmente por não especialistas. Os professores de Ciências consideraram alguns conceitos como mais importantes do que outros, e essas considerações, inevitavelmente, podem influenciar a forma como eles ensinam conservação biológica.

Segundo os autores, os estudantes podem se envolver totalmente na tomada de decisão sobre questões de conservação, mas o uso de valores e conceitos científicos é dependente do contexto. Sendo assim, indica-se a necessidade de discutir uma série de cenários de conservação, a fim de maximizar o entendimento, acerca da complexidade envolvida nesse assunto.

The Morality of Socioscientific Issues: Construal and Resolution of Genetic Engineering Dilemmas

Concentrando-se sobre a forma como os estudantes percebem os aspectos morais das QSC, e como as percepções sobre a moralidade podem influenciar a tomada de decisão dos estudantes, Sadler e Zeidler (2004) realizaram uma pesquisa com universitários da Faculdade de Educação de uma grande universidade pública dos Estados Unidos.

Nesse trabalho, a moralidade foi considerada um aspecto intrínseco de determinados eventos, situações ou problemas. Os autores consideraram que o conhecimento social e de tomada de decisão reside em um dos três domínios universais:

- convencional: está relacionado a questões que são resolvidas mais adequadamente com a aplicação de normas sociais;

- pessoal: representa as decisões que estão sujeitas a uma escolha pessoal e de preferência de um indivíduo. Como por exemplo, nas sociedades ocidentais modernas, os indivíduos geralmente selecionam suas próprias roupas; $\mathrm{e}$

- moral: é definido por prescrições universalmente reconhecidas com base em concepções do bem-estar humano, justiça e direitos. (SADLER; ZEIDLER, 2004, p. 6, tradução da autora).

Sadler e Zeidler (2004) apontaram que, embora a teoria de domínio tenha sido usada como um quadro de investigação por vários pesquisadores ela sofre de uma dependência singular da perspectiva filosófica de moralidade kantiana. Os autores indicaram que pelo menos três perspectivas filosóficas de moralidade poderiam, teoricamente, ser aplicáveis à tomada de 
decisão com dilemas sociocientíficos, são elas: a deontologia, o consequencialismo e a moralidade baseada no cuidado.

Embora muitos trabalhos empíricos da área confirmem que os indivíduos ao tomarem decisão envolvendo QSC considerem os aspectos morais envolvidos nessas questões, Sadler e Zeidler (2004) refletiram sobre a falta de uma análise mais detalhada sobre como essas considerações são elaboradas. Tomando como base esse fato e a pesquisa realizada, os pesquisadores elaboraram um quadro para representação dos padrões morais emergentes na tomada de decisão, com dilemas de engenharia genética e clonagem.

As três categorias que abrangem a tomada de decisão moral, emergentes da pesquisa, são segundo os autores:

- raciocínio moral: esse tipo de raciocínio pode ser baseado em consequências, quando são feitas análises utilitárias dos benefícios e malefícios de determinadas aplicações de engenharia genética, ou em princípios, quando se utilizam prescrições morais na tomada de decisão;

- emoção moral: é influenciada pelas emoções que os estudantes sentem em relação aos cenários de entrevista ou pelos personagens apresentados nos cenários; e

- intuição moral: padrão de resposta intuitivo não apoiado por resoluções com uma análise das consequências, princípios, emoções, ou qualquer outro fator discernível.

As formas dominantes de raciocínio moral que os estudantes empregaram foram o consequencialismo, onde os estudantes resolveram os problemas em termos de resultados de saúde e preocupações com a diversidade. O raciocínio moral baseado em princípios (ou prescrições) onde os estudantes apelaram a princípios como a lei natural, a santidade da vida humana e o direito dos pais. Os estudantes não limitaram sua tomada de decisão apenas a deliberação racional das consequências e princípios de justiça. Os estudantes evocaram de forma consistente considerações de ordem emotiva e afetiva na tomada de decisão moral.

Co-opting Science: A preliminary study of how students invoke science in value-laden discussions

Nielsen (2012) investigou como estudantes de Biologia do ensino secundário entrelaçavam fatos científicos e valores em discussões de grupo sobre uma QSC.

Os resultados sugeriram que os professores e pesquisadores de educação científica precisam estar cientes da complexidade com que a ciência e os valores podem estar entrelaçados 
em tais atividades. Do ponto de vista dos professores, isso significa que muito mais trabalho precisa ser feito, a fim de resolver como deve ser tratada a distinção fato-valor. Do ponto de vista dos pesquisadores, faz-se necessário um entendimento do que eles querem dizer quando se referem que os estudantes devem se tornar adeptos do uso da ciência em questões que vão além do conhecimento científico. Quanto à argumentação, os pesquisadores precisam aplicar quadros analíticos que considerem os aspectos dialéticos da argumentação dos estudantes e não só o conteúdo científico.

Raciocínio moral na tomada de decisões em relação a questões sociocientíficas: o exemplo do melhoramento genético humano

No Brasil, Guimarães, Carvalho e Oliveira (2010), no estudo intitulado Raciocínio moral na tomada de decisões em relação a questões sociocientíficas: o exemplo do melhoramento genético humano, buscaram entender como estudantes do EM percebem e interpretam questões relacionadas à manipulação genética em seres humanos, considerando aspectos relativos a eugenia. Na análise dos resultados foi observada divisão dos estudantes em dois grupos: um deles com uma perspectiva religiosa do tema tratado e outro sem essa característica.

Tanto o grupo que apresentou uma perspectiva religiosa quanto o que não apresentou, afirmaram que a manipulação genética com fins estéticos, ou eugenia positiva, não deveria ser realizada em seres humanos. Os autores discutiram as variações nas opiniões em relação ao assunto tratado no contexto das representações sociais dos estudantes.

b) Concepções de professores sobre o ensino de ética

Uma questão importante, que não tem recebido atenção, está voltada às práticas dos professores e o que pensam sobre propostas que visam infundir a moral na educação científica. Vários pesquisadores da área têm documentado relações significativas entre as crenças de professores, as práticas de ensino e a aprendizagem dos estudantes (ver, por exemplo, BRYAN; ATWATER, 2002; HANEY; CZERNIAK; LUMPE, 1996; LEDERMAN， 1992; TOBIN; LAMASTER, 1995). Portanto, os esforços para desenvolver e promover programas que destacam QSC, bem como a moral e valores associados à ciência, devem representar as perspectivas dos professores sobre essas questões. 
sugestões de mudança, a reforma ficará restrita às páginas de revistas acadêmicas e salas de conferências. (SADLER et al., 2006, p.355, tradução da autora).

Buscando esclarecimentos sobre as concepções de professores acerca do ensino de ética no ensino de Ciências, Barrett e Nieswandt (2010) e Sadler et al. (2006) desenvolveram pesquisas que serão descritas a seguir.

Teaching about Ethics through Socioscientific Issues in Physics and Chemistry: Teacher Candidates' Beliefs

Uma questão importante, que não tem recebido atenção, está voltada para as práticas e o que pensam os professores sobre propostas que visam infundir a moral na educação científica. Pesquisadores da área têm documentado relações significativas entre às crenças de professores, às práticas de ensino e à aprendizagem dos estudantes (ver, por exemplo, BRYAN; ATWATER, 2002; HANEY; CZERNIAK; LUMPE, 1996).

Nas pesquisas interessadas em conhecer a opinião de professores sobre a importância das questões morais e do ensino de ética no ensino de Ciências, Barrett e Nieswandt (2010) analisaram as compreensões de professores sobre QSC e ética.

Para o desenvolvimento desse estudo foram tomados por base três conceitos:

1) ética (desde que explicitamente consideradas nas QSC);

2) crenças (o objeto a ser estudado); e

3) identidade (a base teórica da análise) e, como se relacionam com a ética e as crenças.

A análise dos dados revelou que as crenças sobre o ensino de ética nas disciplinas Física e Química usando QSC derivam uma complexa teia de crenças fundamentais exemplificadas por quatro arquétipos que representaram as identidades dos candidatos: modelo professor cientista, individual, professor e cidadão. Além disso, foi proposto que a justificação para a mudança da crença de um candidato a professor depende dessas identidades. Segue abaixo uma descrição dos arquétipos apresentada pelos autores:

- modelo cientista/engenheiro - é descrito como aquele que têm uma visão muito individualista da ética, seus objetivos para a educação científica servem as necessidades dos cientistas e engenheiros e não necessariamente as da sociedade. A partir do ponto de vista do ensino com QSC, esses professores não iriam incluir estas questões na Química e na Física do ensino médio, mesmo que acreditassem ser interessante para os estudantes; 
- modelo individual - os professores, também têm uma visão muito individualista da ética, tendem a ver a ciência como uma série de teorias e fatos, em vez de prática. O que os distingue do modelo cientista/engenheiro é a crença que o seu papel é ajudar seus estudantes a navegar através da fronteira entre ciência e a não ciência;

- professor modelo - tem como foco ajudar as pessoas a entender a ciência, a fim de ir para cumprimento de carreiras ou para entenderem as questões da ciência quando se deparam com elas. Esses professores expressam mais compromisso com QSC porque eles veem isso como uma maneira de estimular os estudantes a terem mais interesse pela ciência; e

- modelo cidadão - o que distingue o professor modelo cidadão é a concepção da relação entre ética e ciência. As opiniões desse modelo é que a ética é parte integrante de ciência, portanto, não há separação entre a ética pessoal e a da ciência. Esse professor vê as QSC como parte integrante da ciência.

Assim, a presença de cada arquétipo em salas de aula tem ramificações para a forma como um professor inclui as QSC no ensino.

\section{Socioscience and Ethics in Science Classrooms: Teacher Perspectives and Strategies}

Sadler et al. (2006) investigaram a compreensão de professores sobre o ensino de ética no ensino de Ciências. Para isso, os pesquisadores entrevistaram 22 professores da área em questão.

Os resultados das análises revelaram que os professores abraçaram a ideia de inserir QSC em suas aulas, porém, poucos adotaram essa postura na prática. Os autores elaboraram cinco perfis, com vistas a capturar o ponto de vista e as práticas relatadas pelos professores:

- perfil A: os professores abraçaram a noção de difundir currículos de Ciências com QSC e citaram exemplos do uso de temas controversos em suas aulas;

- perfil B: os participantes apoiaram a inserção de QSC nos currículos, mas informaram que existem restrições significativas de efetivar esses objetivos;

- perfil C: os professores não apresentaram compromisso em relação a utilização de QSC e ética;

- perfil D: foi elaborado com base na posição de que a ciência e a educação em Ciências devem ser livres de valores; e 
- perfil E: transcendeu a questão da ética na educação científica; esses professores apontam que toda a educação deve contribuir para o desenvolvimento ético dos estudantes.

Com vistas a sanar as dificuldades dos professores, os pesquisadores concluem que promover currículos que integrem as QSC também exige recursos, ou seja, materiais de apoio para serem utilizados em sala de aula e programas de formação de professores que promovam conexões entre ética e ciência.

Cabe ressaltar que os esforços para desenvolver e promover programas que destacam QSC, bem como a ética, moral e os valores associados à ciência devem representar as perspectivas dos professores sobre essas questões.

c) Propostas pedagógicas

Grande parte das pesquisas sobre QSC tem se concentrado principalmente sobre os estudantes e como eles tomam decisões sobre essas questões. Em contraste, há poucas pesquisas sobre as concepções dos professores em relação ao ensino de ética e sobre propostas/modelos pedagógicos. Não podemos desconsiderar que os professores têm um papel crucial a desempenhar e que, a extensão do seu conhecimento pedagógico irá influenciar suas práticas de ensino e determinar as oportunidades que oferecem para a aprendizagem dos estudantes nessa área.

Os trabalhos enquadrados na categoria "análise de propostas elaboradas e/ou implementadas em sala de aula" foram o estudo de Saunders e Rennie (2013) que elaboraram um modelo pedagógico para a investigação ética em QSC e o de Lee et al. (2012b) que, por sua vez, implementaram um programa com QSC sobre modificação genética e identificaram seus efeitos educacionais. Ambos apresentaram resultados positivos tanto por parte dos professores quanto dos estudantes.

\section{A Pedagogical Model for Ethical Inquiry into Socioscientific Issues in Science}

Saunders e Rennie (2013) considerando que os professores não têm apoio e confiança para enfrentar as QSC em sala de aula desenvolveram um modelo pedagógico com professores que possuía uma série de estágios para explorar uma QSC com os estudantes.

$\mathrm{O}$ projeto de pesquisa foi desenvolvido em duas fases: a fase 1 envolveu $o$ desenvolvimento de um modelo para investigação ética com base na literatura e informações 
de pesquisas realizadas com professores. Na fase 2 o modelo foi criticado e testado por um pequeno grupo de professores de Ciências.

O modelo foi apoiado na utilização de estratégias pedagógicas e em formas de pensamento ético em termos de pluralismo, em que as perspectivas de identidades múltiplas, com base cultural, étnica, religiosa ou perspectivas de gênero, pudessem ser reconhecidas na tomada de decisão ética.

O modelo de Saunders e Rennie (2013) para investigação ética com QSC segue uma série de etapas que serão apresentadas a seguir:

1. preparação do professor;

2. envolvendo os estudantes com uma questão ampla;

3. conhecimento profundo da ciência atrás da questão;

4. reflexão individual e exploração de valores sobre a questão;

5. grupos de discussão sobre questões específicas;

6. decidindo sobre questões específicas ou afirmações controversas;

7. pensamento ético - os estudantes pensam sobre questões ou afirmações a partir de um quadro ético considerando os seguintes princípios: danos e benefícios, direitos e deveres, virtude baseada no cuidado, direito de escolha e pluralis mo;

8. tomada de decisão ética e justificação; e

9. ação, avaliação e metacognição.

Nesse modelo foi utilizada uma série de estratégias, tais como: debate, elaboração de panfleto, apresentação oral, dramatização, pequenos grupos de discussão, jogos de negociação, simulação de entrevista de televisão, estudo de caso, relatórios escritos, vídeo clip, web quest, fotografias, cenários, pôster, pesquisa na internet, jogo de interpretação de papéis (role play), ferramentas de informática dentre outras.

Os resultados positivos emergentes apoiaram a versão final do modelo para investigação ética em termos de seu uso como uma ferramenta pedagógica, que ajudou os professores a melhorar sua prática e promoveu confiança para enfrentar as QSC em salas de aula.

Socioscientific Issues as a Vehicle for Promoting Character and Values for Global Citizens

Apoiados no pressuposto de que as QSC dadas as características humanistas que compõem poderiam servir de veículo para a formação do caráter e valores de cidadãos globais, Lee et al. (2012b) utilizando uma abordagem de método mista implementaram um programa 
com QSC sobre modificação genética para 132 estudantes do nono ano durante 3-4 semanas e identificaram seus efeitos educacionais.

O programa com QSC buscou representar efetivamente três componentes conceitua is chave relacionados a caráter e valores:

- cosmovisão ecológica: foram apresentados méritos e deméritos da modificação genética em relação ao ambiente e ao rompimento do equilibrio da natureza;

- compaixão social e moral: os estudantes foram estimulados a avaliar a questão da modificação genética, pessoalmente, para expressar seus sentimentos, a considerar diversas perspectivas sobre a questão e a colocar-se em uma determinada posição; e

- responsabilidade sociocientífica: conscientização dos estudantes sobre o seu papel como cidadãos e a encontrar soluções para o problema.

Na implementação do programa os autores seguiram as seguintes etapas:

- introdução à modificação genética - o professor introduziu em profundidade a informação científica sobre a modificação genética, os usos correntes e as possibilidades de implicações morais e éticas;

- expressar opiniões iniciais sobre modificação genética - o professor introduziu casos específicos de modificações genéticas e encorajou os estudantes a expressarem livremente suas impressões e opiniões sobre as questões;

- compreensão profunda sobre a modificação genética e suas controvérsias - o professor apresentou seis diferentes perspectivas sobre modificação genética, os estudantes escolheram uma e apresentaram sua posição amparada por evidências em um grupo de debate;

- explorando em profundidade os aspectos morais da modificação genética - os estudantes assistiram a um vídeo com impactos hipotéticos sobre a modificação genética em seres humanos e participaram de uma atividade sobre bebês projetados e, então, consideraram os aspectos morais da modificação genética; $\mathrm{e}$

- chegando a um consenso - os estudantes participaram de uma simulação de reunião na prefeitura como cidadãos e elaboraram um consenso sobre a tecnologia acerca da modificação genética.

Esse estudo demonstrou que a instrução com QSC pode trazer um moderado impacto na promoção da sensibilidade moral e ética e preocupações empáticas. Assim, QSC podem ser 
um meio para educadores de Ciências alcançarem uma integração da educação em Ciências com a moral, o caráter e à educação para a cidadania.

Não podemos desconsiderar que os professores têm um papel crucial a desempenhar e que a extensão do seu conhecimento pedagógico irá influenciar suas práticas de ensino e determinar as oportunidades que oferecem para a aprendizagem dos estudantes nessa área.

d) Formação de professores

Considerando a importância da formação inicial dos professores Silva e Krasilchik (2013) desenvolveram um estudo com licenciandos utilizando temas controversos com considerações éticas, que será descrito a seguir.

Bioética e ensino de Ciências: o tratamento de temas controversos - dificuldades apresentadas por futuros professores de Ciências e biologia

Silva e Krasilchik (2013) em seu estudo analisaram como licenciandos de três instituições de ensino superior lidam com temas controversos como: transgênicos, exame de DNA, limites da ciência e preservação ecológica versus soberania geopolítica, que poderiam ser discutidos com seus futuros estudantes, sobretudo a metodologia a ser utilizada em sala de aula. Os dados apontaram que os estudantes conseguem perceber conflitos éticos nos casos, porém não explicitaram as estratégias de como abordá-los. Para os licenciandos, o professor tem um papel central como expositor dos temas. Os autores concluíram que a formação inicial pouco tem contribuído na instrumentalização dos futuros professores no exercício de tomada de posição e no convívio com a divergência. Destacou-se a importância da bioética na socialização do debate científico e como um valioso instrumento metodológico no ensino de Ciências.

Alguns estudos apoiam essa informação como o de Bryce e Gray (2004) que concluíram ser a formação de professores um sério impedimento para o sucesso das iniciativas com QSC. E sugerem que os professores, além do conhecimento do conteúdo e de QSC, necessitam de habilidades para a estruturação e liderança das discussões em sala de aula.

Outros pesquisadores como Loving e Foster (2000) indicam que ainda existem muitos problemas a serem combatidos por meio do desenvolvimento profissional de professores, atualmente envolvidos em novas dimensões do ensino de Ciências, visando facilitar as discussões sobre as implicações éticas e/ou religiosas da ciência. 
A partir desse levantamento, depreende-se que ainda existem muitas questões abertas à investigação na área de ensino de Ciências. Algumas delas referem-se às QSC e moral, cuja pequena quantidade de pesquisas cria lacunas que poderiam conter relevantes contribuições.

Dos diversos artigos sobre QSC apenas um percentual muito pequeno está relacionado ao estudo da moral presente nessas questões. Apesar do pequeno número de pesquisas desenvolvidas nesse campo, com a análise dos estudos foi possível perceber que as QSC constituem um meio para o estudo da moralidade, e também um meio para educadores de Ciências alcançarem uma integração da educação em Ciências com moral e educação para a cidadania.

Mapear os interesses das pesquisas sobre QSC e moral trouxe argumentos que reiteram a ideia de que os processos de tomada de decisão envolvendo essas questões são guiados por fatores sociais, morais e afetivos. Esses processos podem variar de acordo com o contexto e o referencial de análise, se sou "eu" ou o "outro", sendo que o conhecimento do conteúdo científico parece contribuir pouco em algumas decisões que os indivíduos tomam em contextos sociocientíficos.

Apesar de os estudos apontarem que aspectos morais têm sido considerados na tomada de decisão envolvendo QSC, faz-se necessário esclarecer que a tomada de decisão moral não caracteriza ação moral. Por isso, é preciso considerar-se em primeiro lugar a capacidade de reconhecer os aspectos morais da situação para ser capaz de agir com moralidade.

Grande parte das pesquisas sobre QSC tem se concentrado, principalmente, sobre os estudantes e como eles tomam decisões sobre estas questões. Em contraste, existem lacunas sobre as concepções dos professores em relação ao ensino de ética, propostas pedagógicas e formação de professores.

A compreensão de como os professores de Ciências lidam com tópicos que apresentam implicações morais e de expressão de seus próprios valores em sala de aula, e de estudantes em formação inicial é fundamental, uma vez que as concepções influenciam suas atitudes no processo de ensino. As propostas pedagógicas, também, constituem importantes ferramentas para auxiliar no desenvolvimento de atividades em sala de aula.

Aponta-se, portanto, a necessidade de desenvolvimento de estudos longitudinais visando analisar se a exposição a discussões frequentes com QSC pode contribuir para o desenvolvimento moral. Outro aspecto importante é considerar se estudos com diferentes faixas etárias podem caracterizar se diferenças no desenvolvimento influenciam o raciocínio moral, além de poderem corroborar os dados já existentes. 
Como o desenvolvimento moral é um fenômeno complexo que envolve várias dimensões do desenvolvimento humano, aponta-se a necessidade de considerar as esferas do desenvolvimento moral, como: cognitiva, afetiva, comportamental e motivacional, constituindo, assim, um dos desafios da pesquisa nessa área a construção de referenciais teóricos e metodológicos que articulem diferentes perspectivas de análise psicológica da moralidade.

Um dos objetivos fundamentais do letramento científico é à formação integral do cidadão, para tanto, faz-se necessária à capacidade de interpretar de maneira moral as mudanças produzidas pelo rápido avanço do desenvolvimento científico e tecnológico. Essa proposição fundamenta a importância das QSC e o desenvolvimento moral.

Nesse sentido, consideramos que o ensino das Ciências pode contribuir com o desenvolvimento moral dos estudantes promovendo uma compreensão da dimensão moral da ciência e tecnologia revelando intenções e valores e capacitando os estudantes para agir com responsabilidade na tomada de decisão.

Este trabalho abarcou a produção acadêmica publicada em revistas das áreas de ensino e educação em Ciências, dos estratos A1 e A2 do sistema Qualis/CAPES de 2014 não incluindo outras áreas do conhecimento e artigos que não estivessem disponíveis online. Em vista dessa limitação, é provável que alguns estudos não tenham entrado nesta revisão. Outro aspecto que pode ter dificultado a identificação de artigos refere-se às palavras-chave: o uso dos descritores utilizados pode ter propiciado uma amostra de artigos limitada. Por fim, sugere-se que mais revisões de literatura sejam realizadas a fim de possibilitar a cobertura de eventuais lacunas existentes neste trabalho.

\subsubsection{Abordagem de QSC e moral em aulas de Ciências}

No levantamento realizado, os estudos categorizados como proposta pedagógica para a abordagem de QSC e moral foram o de Saunders e Rennie (2013) e Lee et al. (2012a). Saaunders e Rennie (2013) descreveram uma proposta pedagógica que passou por uma fase de elaboração e, posteriormente, foi testado em sala de aula por professores. Essa proposta incluía um quadro ético e um modelo de tomada de decisão. Nesse estudo os autores apontaram a eficácia da proposta, entretanto, não mostraram os aspectos limitantes inerentes ao contexto escolar e também, do ponto de vista dos professores como a quantidade de aulas utilizadas para a intervenção, nem quanto tempo foi dedicado ao conhecimento científico, bem como o que os 
professores relataram em relação ao currículo da disciplina. Além disso, não apresentaram nenhuma "avaliação" da proposta pedagógica quanto aos aspectos morais dos estudantes.

O estudo de Lee et al. (2012a) também trouxe uma proposta pedagógica desenvolvida em uma escola pública durante 3-4 semanas, porém não indicaram a quantidade de horas utilizadas no desenvolvimento do estudo, apenas o tempo de duração de cada aula (50 min.). Os autores não fizeram considerações específicas quanto as dificuldades encontradas para a implementação da proposta no contexto de sala de aula. Entretanto, analisaram os efeitos de um programa de educação com QSC no EM em relação à visão de mundo ecológica, compaixão social e moral e responsabilidade sociocientífica.

Em nossa pesquisa encontramos semelhanças e diferenças em relação as propostas acima citadas. Apontamos como pontos de contato o fato de estar relacionado a implementação de uma proposta pedagógica para o trabalho com QSC e moral. Entretanto os estudos não apresentavam a quantidade de aulas utilizadas na intervenção, nem apontavam as implicações pedagógicas das propostas, que foi foco do nosso estudo. A utilização por Saunders e Rennie (2013) de um modelo de tomada de decisão moral foi um elemento não utilizado em nossa proposta. Entretanto, no final desta pesquisa percebemos a importância desses modelos para orientar a tomada de decisão moral.

Os estudos enfatizaram a existência de elementos importantes tais como a preparação do professor; o conhecimento científico, a clarificação dos valores envolvidos na questão, a aplicação de um quadro ético e a tomada de decisão.

A utilização de atividades pedagógicas variadas foi outro aspecto priorizado nos estudos tais como: debate, elaboração de panfleto, apresentação oral, dramatização, pequenos grupos de discussão, jogos de negociação, estudo de caso, relatórios escritos, vídeo, web quest, fotografias, cenários, pôster, pesquisa na internet, jogo de interpretação de papéis (role play), dentre outras. Neste estudo priorizamos a discussão como atividade pedagógica.

Como visto, são poucos os estudos da área que trazem uma proposta pedagógica, isso revela a existência de uma lacuna, que dificulta o desenvolvimento desse tipo de proposta por parte dos professores e demais interessados. Assim, percebeu-se a necessidade do desenvolvimento de mais estudos com a implantação de propostas pedagógicas para o trabalho com QSC e moral com vistas à um aporte de conhecimento para a área, o que justificou a realização deste estudo. 


\subsection{Um olhar sobre as inter-relações CTS, conhecimento, linguagem científica, ética, moral e valores em documentos educacionais para o Ensino Médio}

$\mathrm{Na}$ versão preliminar deste trabalho foram analisados os documentos curriculares educacionais para o EM (Parâmetros Curriculares Nacionais para o Ensino Médio - PCNEM, 1998; Orientações Complementares aos Parâmetros Curriculares Nacionais para o Ensino Médio - PCN+, 2002; e Orientações Curriculares para o Ensino Médio - OCEM, 2006) na área de Ciências da Natureza e suas Tecnologias (Biologia, Física e Química).

Entretanto, devido ao fato dos mencionados documentos não terem valor legal no momento, em decorrência, da promulgação das novas DCNEM em 2013, optamos pela análise desse novo documento e da versão preliminar da BNCC (BRASIL, 2015), uma vez, que ainda não foram editados novos documentos.

Nesse contexto, procuramos evidenciar nos documentos supracitados a presença dos termos: científico e tecnológico e suas variações, buscando identificar o contexto e os significados relacionados.

Para tanto, foi realizada uma busca utilizando as palavras chave: sócio-científico, sociocientífico, CTS, ciência-tecnologia-sociedade, tecnocientífico, tecnociência, da ciência e da tecnologia, científico e tecnológico, da ciência na tecnologia, a ciência e a tecnologia, científico-tecnológica. Após a identificação dos termos da busca, seguiu-se a análise dos documentos oficiais utilizando a estratégia metodológica de Análise Textual Discursiva (MORAES; GALIAZZI, 2007).

Com base nos três aspectos que têm recebido destaque nos estudos sobre letramento científico identificados por Santos (2007): natureza da ciência, linguagem científica e aspectos sociocientíficos, procedeu-se a categorização, no entanto, consideramos apenas uma categoria apresentada pelo referido autor que foi, linguagem científica, a qual denominou-se conhecimento e linguagem científica e propusemos duas outras: inter-relações CTS e aspectos éticos e valores, uma vez que, esses últimos se encontram relacionados aos nossos objetivos de pesquisa.

Cabe destacar que, na categoria inter-relações CTS relacionou-se os seguintes aspectos: natureza da ciência, tomada de decisão, formação para a cidadania, caráter histórico e social da ciência e tecnologia e as QSC. Como linguagem científica, consideramos o uso de termos técnicos e a aplicação de conceitos científicos. Na categoria aspectos éticos e valores, os mesmos estavam relacionados à produção e aplicação do conhecimento científico e tecnológico, chamando à reflexão sobre as relações entre a ciência, a tecnologia e a sociedade. 


\subsubsection{Diretrizes Curriculares Nacionais para o Ensino Médio}

As DCNEM (BRASIL, 2013) orientam o planejamento curricular das escolas e dos sistemas de ensino com o objetivo de promover a equidade de aprendizagem, garantindo que conteúdos básicos sejam ensinados para todos os estudantes, sem deixar de considerar os diversos contextos nos quais eles estão inseridos.

Quadro 6 - Relação das citações extraídas das DCNEM e as respectivas categorias de análise

\begin{tabular}{|l|}
\hline \multicolumn{1}{|c|}{ Inter-relações CTS } \\
\hline "Assim, evidencia-se a unicidade entre as dimensões científico-tecnológico-cultural, a partir da compreensão \\
do trabalho em seu sentido ontológico" (p. 162).
\end{tabular}

"A formação geral do estudante em torno dos fundamentos científico-tecnológicos, assim como sua qualificação para o trabalho, sustentam-se nos princípios estéticos, éticos e políticos que inspiram a Constituição Federal e a LDB” (p.169)

"IV - a compreensão dos fundamentos científico-tecnológicos dos processos produtivos, relacionando a teoria com a prática" (p. 192)

“É, portanto, na busca de desenvolver estratégias pedagógicas que contribuam para compreender como o trabalho, enquanto mediação primeira entre o ser humano e o meio ambiente, produz social e historicamente ciência e tecnologia e é influenciado e influencia a cultura dos grupos sociais" (p. 185)

"VIII - realização de parceria com órgãos, tais como os de assistência social, desenvolvimento e direitos humanos, cidadania, trabalho, ciência e tecnologia, lazer, esporte, turismo, cultura e arte, saúde, meio ambiente" (p. 153)

\section{Conhecimento e Linguagem científica}

"§ $3^{\circ}$ A tecnologia é conceituada como a transformação da ciência em força produtiva ou mediação do conhecimento científico e a produção, marcada, desde sua origem, pelas relações sociais que a levaram a ser produzida" (p. 195)

"Segundo Terigi (1999), tais âmbitos de referência podem ser considerados como correspondendo aos seguintes espaços: I - instituições produtoras de conhecimento científico (universidades e centros de pesquisa)" (p. 182)

"A extensão das capacidades humanas, mediante a apropriação de conhecimentos como força produtiva, sintetiza o conceito de tecnologia aqui expresso. Pode ser conceituada como transformação da ciência em força produtiva ou mediação do conhecimento científico e a produção, marcada desde sua origem pelas relações sociais que a levaram a ser produzida" (p. 162)

\section{Ética, moral e valores}

"III - o aprimoramento do educando como pessoa humana, incluindo a formação ética e o desenvolvimento da autonomia intelectual e do pensamento crítico" (p. 194)

“Ao contrário, a incorporação das ciências humanas na formação do trabalhador é fundamental para garantir o currículo integrado. Por exemplo: história social do trabalho, da tecnologia e das profissões; compreensão, no âmbito da geografia, da produção e difusão territorial das tecnologias e da divisão internacional do trabalho; filos ofia, pelo estudo da ética e estética do trabalho" [...] (p. 190)

"Voltados à divulgação de valores fundamentais ao interes se social e à preservação da ordem democrática, os conhecimentos" [...] (p. 185)

" $\$ 4^{\circ}$ A cultura é conceituada como o processo de produção de expressões materiais, símbolos, representações e significados que correspondem a valores éticos, políticos e estéticos que orientam as normas de conduta de uma sociedade" (p. 195) 
“II - uma dimensão não explícita, constituída por relações entre os sujeitos envolvidos na prática escolar, tanto nos momentos formais, como informais das suas atividades e nos quais trocam ideias e valores, constituindo o currículo oculto, mesmo que não tenha sido pré-determinado ou intencional” (p. 180)

"Os conhecimentos escolares são reconhecidos como aqueles produzidos pelos homens no processo his tórico de produção de sua existência material e imaterial, valorizados e selecionados pela sociedade e pelas escolas que os organizam a fim de que possamser ensinados e aprendidos, tornando-se elementos do desenvolvimento cognitivo do estudante, bem como de sua formação ética, estética e política" (p. 179)

"Embora na LDB a gestão democrática apareça especificamente como orientação para o ensino público, ela está indicada, implicitamente, para todas as instituições educacionais nos Arts. 12 e 13, entre as quais as instituições privadas, que não devem se furtar ao processo, sob pena de contrariarem os valores democráticos e participativos que presidem nossa sociedade" (p. 174)

“Kuenzer (2000) chama a atenção para as finalidades e os objetivos do Ensino Médio, que se resumem (...) no compromisso de educar o jovem para participar política e produtivamente do mundo das relações sociais concretas com comportamento ético e compromisso político, através do desenvolvimento da autonomia intelectual e da autonomia moral” (p. 170)

"III - o aprimoramento do educando como pessoa humana incluindo a formação ética e o desenvolvimento da autonomia intelectual e do pensamento crítico" (p. 169)

"Este artigo possibilita-nos afirmar que a finalidade da educação é de tríplice natureza:

I - o pleno desenvolvimento do educando deve ser voltado para uma concepção teórico educacional que leve em conta as dimensões: intelectual, afetiva, física, ética, estética, política, social e profissional” (p. 169)

"Tomar o educando em suas múltiplas dimensões tem como finalidade realizar uma educação que o conduza à autonomia, intelectual e moral” (p. 167)

“A PNEA entende por esta educação os processos por meio dos quais o indivíduo e a coletividade constroem valores sociais, conhecimentos, habilidades, atitudes e competências voltadas para a conservação do meio ambiente, bem de uso comum do povo, ess encial à sadia qualidade de vida e sua sustentabilidade".P. 166

"Estado Democrático, destinado a assegurar o exercício dos direitos sociais e individuais, a liberdade, a segurança, o bem-estar, o desenvolvimento, a igualdade e a justiça como valores supremos de uma sociedade fraterna, pluralista e sem preconceitos" (p. 164)

"Muito além do conhecimento e da utilização de equipamentos e materiais, a prática de pesquisa propicia o desenvolvimento da atitude científica, o que significa contribuir, entre outros aspectos, para o desenvolvimento de condições de, ao longo da vida, interpretar, analis ar, criticar, refletir, rejeitar ideias fechadas, aprender, buscar soluções e propor alternativas, potencializadas pela investigação e pela responsabilidade ética assumida diante das questões políticas, sociais, culturais e econômicas” (p. 164)

"O fato dessas novas tecnologias se aproximarem da escola, onde os alunos, às vezes, chegam com muitas informações, reforça o papel dos professores no tocante às formas de sistematização dos conteúdos e de estabelecimento de valores" (p. 162)

"Entende-se cultura como o resultado do esforço coletivo tendo em vista conservar a vida humana e consolidar uma organização produtiva da sociedade, do qual resulta a produção de expressões mate riais, símbolos, representações e significados que correspondema valores éticos e estéticos que orientam as normas de conduta de uma sociedade" (p. 162)

"A formação dos indivíduos é hoje atravessada por umnúmero crescente de elementos. Se antes ela se produzia, dominantemente, no espaço circunscrito pela família, pela escola e pela igreja, em meio a uma razoável homogeneidade de valores, muitas outras instituições, hoje, participam desse jogo, apresentando formas de ser e de viver heterogêneas" (p. 156)

Fonte: elaboração da autora.

No quadro 6, apresentamos as categorias de análise relacionadas às citações extraídas do documento, onde identificamos cinco chamadas para a categoria inter-relações CTS, três para conhecimento e linguagem científica e 25 para ética, moral e valores. 
Na categoria inter-relações CTS emergiram considerações acerca da unicidade entre ciência, tecnologia e cultura, como construção histórica e cultural, da compreensão dos fundamentos científico-tecnológicos dos processos produtivos e da necessidade de relacionar a teoria com a prática.

Reiteramos essa ideia, apresentando a citação abaixo referente ao item 6, Função do EM no marco legal, há afirmação de que a finalidade da educação é de tríplice natureza:

\footnotetext{
I - o pleno desenvolvimento do educando deve ser voltado para uma concepção teórico educacional que leve em conta as dimensões: intelectual, afetiva, física, ética, estética, política, social e profissional;

II - o preparo para o exercício da cidadania centrado na condição básica de ser sujeito histórico, social e cultural; sujeito de direitos e deveres; e

III - a qualificação para o trabalho fundamentada na perspectiva de educação como um processo articulado entre ciência, tecnologia, cultura e trabalho (p. 169) [grifo nosso].
}

Destacamos ainda que a fundamentação para a organização curricular do EM nas novas Diretrizes (BRASIL, 2013) está centrada no trabalho, na ciência, na tecnologia e na cultura como dimensões da formação humana.

Em relação à categoria conhecimento e linguagem científica, essa apresentou uma baixa ocorrência. Dela depreende-se que o conhecimento científico é marcado pelas relações sociais e a tecnologia é definida como mediação do conhecimento científico e a produção.

As ocorrências relacionadas à ética, à moral e aos valores apareceram relacionadas a quatro dimensões: ao aprimoramento do educando no que tange: (1) a autonomia intelectual, moral, do pensamento crítico; (2) a responsabilidade ética diante das questões políticas, sociais e culturais; (3) a educação como forma de socializar as pessoas de acordo com valores e padrões culturais e ético-morais da sociedade; e (4) que as ações administrativas e pedagógicas dos sistemas de ensino e das escolas devam ser coerentes com princípios estéticos, políticos e éticos.

No contexto das DCNEM percebeu-se a incorporação da ética, moral e valores visando conciliar humanismo e tecnologia, exercício de cidadania e conhecimento acerca da ciência e tecnologia, formação ética e autonomia intelectual e moral, uma formação comprometida com o pleno desenvolvimento dos indivíduos. A ética apresentada nas DCNEM é caracterizada como ética da identidade, uma vez que reconhece a educação como um processo de construção de identidades, que tem como finalidade o desenvolvimento da autonomia moral e intelectual do indivíduo. 


\subsubsection{Base Nacional Comum Curricular (versão preliminar)}

A Base Nacional Comum Curricular em sua versão preliminar busca atender ao Plano Nacional de Educação e está sendo elaborada de acordo com as Diretrizes Curriculares Nacionais Gerais para a Educação Básica. Essa base apresenta doze Direitos de Aprendizagem que orientam as escolhas realizadas pelos componentes curriculares na definição dos objetivos de aprendizagem, que devem considerar três dimensões básicas: ética, estética e política.

Esse documento prevê uma base comum constituída por conhecimentos fundamenta is que todos os estudantes brasileiros devem ter acesso, e uma diversificada que deve ser elaborada em diálogo com a base comum e com a realidade de cada escola.

A área das Ciências da Natureza para o Ensino Fundamental e Médio é fundamentada por quatro dimensões formativas que constituem os eixos que devem orientar a proposição de um currículo. Esses eixos são: conhecimento conceitual das Ciências da Natureza; contextualização histórica, social e cultural das Ciências da Natureza; processos e práticas de investigação em Ciências da Natureza; e linguagens das Ciências da Natureza.

Os objetivos gerais da área são:

- compreender a ciência como um empreendimento humano, construído histórica e socialmente;

- apropriar-se de conhecimentos das Ciências da Natureza como instrumento de leitura do mundo;

- interpretar e discutir relações entre a ciência, a tecnologia, o ambiente e a sociedade;

- mobilizar conhecimentos para emitir julgamentos e tomar posições a respeito de situações e problemas de interesse pessoal e social relativos às interações da ciência na sociedade;

- saber buscare saber fazer uso de informações e de procedimentos de investigação com vistas a propor soluções para problemas que envolvem conhecimentos científicos;

- desenvolver senso crítico e autonomia intelectual no enfrentamento de problemas e na busca de soluções, vis ando transformações sociais e construção da cidadania;

- fazer uso de modos de comunicação e de interação para aplicação e divulgação de conhecimentos científicos e tecnológicos; e

- refletir criticamente sobre valores humanos, éticos e morais relacionados com a aplicação dos conhecimentos científicos e tecnológicos (BRASIL, 2015, p. 170). 
Quadro 7 - Relação das citações extraídas da BNCC versão preliminar e as respectivas categorias de análise

\begin{tabular}{|c|}
\hline Inter-relações CTS \\
\hline $\begin{array}{l}\text { "O conhecimento conceitual pode, portanto, promover uma aproximação dos jovens com os conhecimentos } \\
\text { produzidos pela Biologia que circulam em mídias eletrônicas às quais têm acesso e nas discussões } \\
\text { sociopolíticas sobre temas que envolvem a ciência e tecnologia" (p. 205) }\end{array}$ \\
\hline $\begin{array}{l}\text { "Trabalhar na interlocução ciência, tecnologia e sociedade proporciona uma ampliação da percepção do papel } \\
\text { da Física como saber social" (p. 225) }\end{array}$ \\
\hline $\begin{array}{l}\text { "Dá mesma forma, há ênfase nas aplicações da Química importantes, para que o/a estudante seja capaz de } \\
\text { argumentar, de se posicionar e tomar decisões acerca de uma variedade de questões sociocientíficas, de modo } \\
\text { a se tornar um cidadão crítico e participativo que saiba usar o conhecimento químico" (p. 246) }\end{array}$ \\
\hline $\begin{array}{l}\text { "O conhecimento biológico tem dimensões sociais, tecnológicas, culturais, éticas, afetivas e artísticas. A } \\
\text { discussão de questões sociocientíficas pode ser utilizada para contemplar tais dimensões" (p. 205) }\end{array}$ \\
\hline $\begin{array}{l}\text { "No entanto, o mesmo desenvolvimento científico e tecnológico de notáveis progressos na produção e nos } \\
\text { serviços também pode promover impactos e desequilibrios na natureza e na sociedade, que demandam outras } \\
\text { sabedorias, não somente científicas, para serem compreendidos e tratados" (p. 166) }\end{array}$ \\
\hline Conhecimento e Linguagem científica \\
\hline $\begin{array}{l}\text { "[...] considerando a aquisição do conhecimento científico envolve o uso de múltiplas linguagens para a } \\
\text { interpretação e para a construção de dados, de gráficos e de tabelas, assim como para o contato com textos de } \\
\text { diferentes gêneros, como textos científicos e informativos, relatórios, seja em práticas de leitura ou de produção } \\
\text { desses textos, seja em práticas de oralidade, ou em atividades que envolvam outras formas de representação } \\
\text { como os desenhos" (p. 176) }\end{array}$ \\
\hline $\begin{array}{l}\text { "[...] a compreensão de questões culturais, sociais, éticas e ambientais, associadas ao uso dos recursos naturais } \\
\text { e à utilização do conhecimento científico e da tecnologia" (p. 166) }\end{array}$ \\
\hline $\begin{array}{l}\text { "O ensino de Ciências da Natureza tem compromisso com uma formação que prepare o sujeito para interagir e } \\
\text { atuar em ambientes diversos, considerando uma dimensão planetária, uma formação que possa promover a } \\
\text { compreensão sobre o conhecimento científico pertinente em diferentes tempos [...]" (p. 166) }\end{array}$ \\
\hline $\begin{array}{l}\text { "Conhecimento conceitual das Ciências da Natureza - neste eixo são enfatizados os conteúdos conceituais } \\
\text { específicos de cada componente curricular - o saber sistematizado, leis teorias e modelos. Os conteúdos } \\
\text { conceituais poderão ser propostos do currículo a partir de estudos sobre fenômenos, processos e situações que } \\
\text { suscitamo domínio de conhecimentos científicos para a sua compreensão" (p. 168) }\end{array}$ \\
\hline $\begin{array}{l}\text { "Linguagens das Ciências da Natureza - neste eixo é ressaltada a importância do domínio das linguagens } \\
\text { específicas das Ciências da Natureza e das múltiplas linguagens envolvidas na comunicação e na divulgação } \\
\text { do conhecimento científico" (p. 169) }\end{array}$ \\
\hline $\begin{array}{l}\text { "Saber buscar e fazer uso de informações e de procedimentos de investigação com vistas a propor soluções } \\
\text { para problemas que envolvem conhecimentos científicos" (p. 170) }\end{array}$ \\
\hline $\begin{array}{l}\text { "Fazer uso de modos de comunicação e de interação para aplicação e divulgação de conhecimentos científicos } \\
\text { e tecnológicos" (p.170) }\end{array}$ \\
\hline $\begin{array}{l}\text { "Refletir criticamente sobre valores humanos, éticos e morais relacionados com a aplicação dos conhecimentos } \\
\text { científicos e tecnológicos" (p. 170) }\end{array}$ \\
\hline $\begin{array}{l}\text { "Buscar e fazer uso de informações, de procedimentos de investigação com vistas a propor soluções para } \\
\text { problemas que envolvem conhecimentos científicos" (p. 173) }\end{array}$ \\
\hline $\begin{array}{l}\text { "Estudos sobre as Ciências da Natureza podem contribuir para que eles compreendam problemas e situações } \\
\text { que envolvem questões das ciências e da tecnologia e busquem soluções, estabelecendo relações entre os } \\
\text { conhecimentos científicos e a sociedade, reconhecendo fatores que podem influenciar as transformações de } \\
\text { uma dada realidade" (p. 174) }\end{array}$ \\
\hline $\begin{array}{l}\text { "Fazer uso de modos de comunicação e de interação para aplicação e divulgação de conhecimentos científicos } \\
\text { e tecnológicos" (p. 203) }\end{array}$ \\
\hline
\end{tabular}


Quadro 7 - Relação das citações extraídas da BNCC versão preliminar e as respectivas categorias de análise (cont.)

\begin{tabular}{|c|}
\hline Conhecimento e Linguagem científica \\
\hline $\begin{array}{l}\text { "Por meio dessa abordagem, pretende-se, também, construir uma visão mais crítica do conhecimento científico } \\
\text { e tecnológico e de sua relação com a sociedade [...]" (p. 205) }\end{array}$ \\
\hline $\begin{array}{l}\text { "Por exemplo, é proposto que o objetivo "Compreender a importância das controvérsias para a construção do } \\
\text { conhecimento científico, no contexto das disputas em torno dos modelos explicativos para a origem da vida } \\
\text { [...]" (p. 210) }\end{array}$ \\
\hline $\begin{array}{l}\text { "Consolidar a compreensão do papel que as controvérsias apresentamna produção do conhecimento científico, } \\
\text { especialmente, se o professor mediar intencionalmente essa relação entre os assuntos" (p. 210) }\end{array}$ \\
\hline $\begin{array}{l}\text { "Compreender a importância das controvérsias para a construção do conhecimento científico, no contexto das } \\
\text { disputas em torno dos modelos explicativos para a origem da vida" (p. 213) }\end{array}$ \\
\hline $\begin{array}{l}\text { "Compreender o significado que evidencia a teoria de modelos apresentados na produção do conhecimento } \\
\text { científico, no contexto da análise da recepção do darwinismo no século XIX [...]" (p. 216) }\end{array}$ \\
\hline $\begin{array}{l}\text { "O conhecimento científico dialoga com outros elementos da cultura representados, por exemplo, em } \\
\text { produções da literatura, das artes plásticas, do teatro e da música" (p. 226) }\end{array}$ \\
\hline $\begin{array}{l}\text { "Elaborar e apresentar relatórios de experimentos e/ou de pesquisas teóricas investigativas, utilizando } \\
\text { linguagem científica adequada e meios atuais de comunicação e informação" (p. 232) }\end{array}$ \\
\hline Ética, moral e valores \\
\hline $\begin{array}{l}\text { "Participar ativamente da vida social, cultural e política, de forma solidária, crítica e propositiva, reconhecendo } \\
\text { direitos e deveres, identificando e combatendo injustiças, e se dispondo a enfrentar ou mediar eticamente } \\
\text { conflitos de interesse" (p. 09) }\end{array}$ \\
\hline $\begin{array}{l}\text { "Desde o letramento inicial até as etapas conclusivas da educação básica há aspectos da formação que envolvem } \\
\text { todas as áreas de conhecimento, como o desenvolvimento da sociabilidade, da curiosidade, de atitudes éticas, } \\
\text { de qualificação para compreender e empregar inúmeras tecnologias, para elaborar visões de mundo e } \\
\text { sociedade"(p. 11) }\end{array}$ \\
\hline $\begin{array}{l}\text { "Os doze Direitos de Aprendizagem enunciados no referido texto constituem um conjunto de proposições que } \\
\text { orientam as escolhas feitas pelos componentes curriculares na definição de seus objetivos de aprendizagem, } \\
\text { consideradas as dimensões ética, estética e política de efetivação daqueles direitos de aprendizagem e } \\
\text { desenvolvimento"(p. 13) }\end{array}$ \\
\hline $\begin{array}{l}\text { "Os temas integradores dizem respeito a questões que atravessam as experiências dos sujeitos em seus } \\
\text { contextos de vida e atuação e que, portanto, intervêm em seus processos de construção de identidade e no modo } \\
\text { como interagem com os outros sujeitos, posicionando-se ética e criticamente sobre e no mundo nessas } \\
\text { interações. Contemplam, portanto, para além da dimensão cognitiva, as dimensões política, ética e estética da } \\
\text { formação dos estudantes"(p.14) }\end{array}$ \\
\hline $\begin{array}{l}\text { "[...] a compreensão de questões culturais, sociais, éticas e ambientais, as sociadas ao uso dos recursos naturais } \\
\text { e à utilização do conhecimento científico e das tecnologias"(p. 166) }\end{array}$ \\
\hline $\begin{array}{l}\text { "Refletir criticamente sobre valores humanos, éticos e morais relacionados à aplicação dos conhecimentos } \\
\text { científicos e tecnológicos" (p. 203) }\end{array}$ \\
\hline $\begin{array}{l}\text { "O trabalho com o componente curricular Biologia, no Ensino Médio, tem se realizado também pela ampliação } \\
\text { das interfaces entre essa ciência, os processos e os produtos tecnológicos e as questões de âmbito sociale caráter } \\
\text { político, ético e moral" (p. 204) }\end{array}$ \\
\hline "O conhecimento biológico tem dimensões sociais, tecnológicas, culturais, éticas, afetivas e artísticas" (p. 205) \\
\hline $\begin{array}{l}\text { "Analisar as implicações éticas e sociais do acesso ao aconselhamento genético e a diagnósticos moleculares } \\
{[\ldots] " \text { (p. 221) }}\end{array}$ \\
\hline $\begin{array}{l}\text { "[...] do sentido de pertença e de intervenções de sujeitos nas transformações das sociedades; as identidades e } \\
\text { as alteridades; as memórias; a ética; a estética; as desigualdades sociais; as ideologias; os modos de produção } \\
\text { e de apropriações; os modos de pensar, de crer e de agir das pessoas" (p. 258) }\end{array}$ \\
\hline
\end{tabular}


Quadro 7 - Relação das citações extraídas da BNCC versão preliminar e as respectivas categorias de análise (cont.)

\begin{tabular}{|l|}
\hline \multicolumn{1}{|c|}{ Ética, moral e valores } \\
\hline $\begin{array}{l}\text { "O conhecimento proporcionado pela Física é social, o que traz implicações de natureza política, econômica, } \\
\text { também, ética" (p. 225) }\end{array}$ \\
\hline "Portanto, a apropriação dos conhecimentos e a formação de atitudes e valores ocorrem a partir do \\
desenvolvimento integrado dos saberes das áreas das Ciências da Natureza articulados com outras áreas" (p. \\
177)
\end{tabular}

Fonte: elaboração da autora.

No quadro 7 são apresentadas as citações extraídas da versão preliminar da BNCC (BRASIL, 2015) referentes as categorias que afloraram da análise do documento em questão.

Na versão preliminar da BNCC (BRASIL, 2015) foram encontradas cinco chamadas relacionadas à categoria inter-relações CTS, 19 sobre conhecimento e linguagem científica e 12 sobre aspectos éticos, moral e valores. Nessa categoria emergiram considerações acerca das dimensões que envolvem a ciência e tecnologia como: da ciência como construção histórica e cultural, demonstrando a necessidade de envolver o reconhecimento e discussão de aspectos práticos e éticos da ciência no mundo contemporâneo.

A partir das citações extraídas desse documento, identificamos a incorporação das QSC com vistas à necessidade de formação de um cidadão capaz de refletir criticamente sobre os valores éticos e morais, de se posicionar na tomada de decisão acerca dos problemas relacionados à aplicação dos conhecimentos científicos e tecnológicos.

A importância do conhecimento científico relacionado às Ciências da Natureza centrase na sua utilização prática, na necessidade desse conhecimento para a identificação e busca de soluções para situações e problemas que envolvam os conhecimentos científicos e a sociedade.

Quanto à linguagem científica essa é indissociável do conhecimento científico, uma vez que esse envolve o uso de múltiplas linguagens para a sua elaboração e interpretação, daí a importância da aquisição e uso desse tipo de linguagem.

Dessa forma, pode-se afirmar que a BNCC (2015) em sua versão preliminar no que diz respeito à inclusão de QSC está em concordância com o novo texto das DCNEM.

A partir dessa análise depreende-se que os documentos oficiais direcionados ao Ensino Médio, propõem à inserção de QSC, das inter-relações entre à ciência, à tecnologia, o ambiente e à sociedade, buscando a formação de cidadãos críticos e éticos. Nesse sentido, é necessário dar voz ao estudante e, consequentemente, fazer emergir o contexto científico e tecnológico que o circunda, pois tais concepções estão presentes em sua visão de mundo. 
No que se refere aos aspectos éticos, moral e valores, observou-se que essa temática comparece nos dois documentos em questão. A própria Lei de Diretrizes e Bases da Educação (LDB/1996) propõe no Art. 35, inciso II que uma das finalidades do Ensino Médio é "a preparação básica para o trabalho e a cidadania do educando como pessoa humana, incluindo a formação ética e o desenvolvimento da autonomia intelectual e do pensamento crítico". A partir desses documentos fica evidente que a educação brasileira deve ser norteada por princípios que assegurem a dignidade da pessoa humana, a igualdade de direitos entre as pessoas, a participação e a corresponsabilidade pela vida social.

A identificação das categorias de análise especificamente da ética, moral e valores e sua inter-relação com o conhecimento científico e tecnológico, nos indicam uma convergência entre esses documentos apontando-nos a necessidade de inserção desses aspectos nas aulas de Ciências.

Essa revisão das perspectivas curriculares indicou que, embora os curriculistas reconheçam a necessidade do desenvolvimento de uma autonomia moral e intelectual e do letramento científico com vistas a formação para a cidadania, o currículo pretendido é, por vezes utópico, pois desconsidera as especificidades da maioria das escolas brasileiras, e o currículo implementado ainda é em grande parte dominado pelo conteúdo.

Não é possível pensar a ciência e a tecnologia nos dias de hoje, fora do contexto da sociedade, nem a sociedade fora das relações entre a ciência e tecnologia. A relação ciência e tecnologia tem transformado a realidade em que vivemos e influenciado culturalmente a forma como pensamos e como nos comportamos. A necessidade de um avanço na compreensão dos sentidos da ciência e, principalmente, da tecnologia, devido ao seu caráter polissêmico, associado a uma adequada consciência e competência para integrar aspectos técnico-científicos nas decisões pessoais, sociais, morais e políticas, é o que se espera de um ensino Ciências que possibilite as relações CTS.

Pensar o ensino de Ciências relacionado ao desenvolvimento moral e que privilegie as relações CTS é criar condições para que os estudantes orientem suas condutas por valores que respondam às exigências do seu tempo.

Assim, entendemos que o ensino de Ciências pode contribuir com o desenvolvimento da autonomia moral dos estudantes ao considerar: o conhecimento da ciência e da tecnologia como construção social, histórica e cultural, a não neutralidade científica e os problemas associados ao avanço do conhecimento científico-tecnológico e a questão ética, como uma consequência social do próprio do desenvolvimento científico-tecnológico. Essa autonomia 
constitui uma condição indispensável para os juízos de valor e as escolhas inevitáveis que os indivíduos terão que fazer ao longo de suas vidas.

É importante que os estudantes conheçam o contexto em que funciona a ciência, e que a construção do conhecimento científico é pautada por valores cognitivos ou epistêmicos, entretanto, os valores sociais ou não epistêmicos assumem um papel importante quando se trata de QSC. Consideramos que a moral que envolve os contextos sociocientíficos é influenciada por valores sociais que guiarão aos juízos de valor e, portanto, a tomada de decisão. 



\section{ESTUDOS DA MORALIDADE}

Numa época em que o avanço do desenvolvimento científico e tecnológico tem produzido benefícios, mas atrelados a eles muitos impactos negativos e conflitos de interesses, não seria de se estranhar que surjam questões controvertidas que levam a elaboração de juízos de valor. Mas o que leva um indivíduo a decidir sobre qual caminho seguir, que opção escolher? Diante da certeza sempre premente da escolha, a dúvida é: como saber qual a melhor decisão a tomar? Que impactos terá essa decisão?

Uma teoria moral nasce da necessidade de justificar racionalmente as escolhas morais. Dito em outras palavras "a razão moral se vê forçada a se converter em razão teórica por que se choca na realidade com a existência de conflitos e desacordos morais" (FERRER; ÁLVAREZ, 2005, p.85). Esses desacordos surgem quando o agente moral tem que escolher entre duas ou mais alternativas, sendo que nenhuma delas esteja livre de problemas éticos.

Como neste trabalho buscamos identificar os aspectos morais adotados pelos estudantes relativos às QSC, com o propósito de revelar possíveis indicadores da relação entre abordagem de QSC e aspectos morais, utilizaremos como arcabouço teórico contribuições do campo da psicologia e da filosofia moral. Este capítulo fornecerá, então, uma caracterização acerca do domínio moral, raciocínio moral e a descrição de teorias morais que têm sido comumente utilizadas no estabelecimento e análise de quadros morais, caracterizando o que as aproximam e o que as distanciam.

\subsection{Domínio moral}

Apesar das muitas tentativas de definição do domínio moral não há uma definição universalmente aceita até o momento. Entretanto, existem características gerais partilhadas por muitas abordagens. Segundo Bartels et al. (2014) juízos morais frequentemente dizem respeito a cursos de ação que acarretam algum dano, especialmente os que envolvem perda de vidas ou dano físico, perda de propriedade legítima, perda de privacidade ou outras ameaças à autonomia. Juízos morais, também tendem a ser desencadeados por ações que afetam não só o ator, mas os outros.

De acordo com Nucci (2000, p. 75) a moralidade pode ser definida "a partir dos conceitos do indivíduo, de seus raciocínios, e de ações que se referem ao bem-estar, aos direitos, e ao tratamento justo das pessoas". Nesse contexto, o autor distingue moralidade de convenção 
social, associando a definição de moralidade em termos de justiça, bem-estar e direitos e de convenção social como padrões de conduta consensual de determinados grupos sociais. Por exemplo, normas ou padrões de vestuário, como as pessoas devem dirigir-se umas às outras etc.

De acordo com Rottman e Young (2015) a teoria do domínio social tem promovido avanços na compreensão do desenvolvimento moral, entretanto, algumas críticas têm surgido. Em culturas tradicionais ou não ocidentais a distinção entre os domínios moral e convencional é menos pronunciada, e talvez até mesmo ausente. Shweder, Mahapatra e Miller (1987) descobriram que não há distinção substancial de domínio entre os hindus na Índia, onde indivíduos tratam muitas normas como morais, mesmo quando elas não têm consequências aparentes para o bem-estar dos outros.

Haidt, Koller e Dias (1993) apresentando histórias sobre ações ofensivas sem vítimas (tais como limpeza de um vaso sanitário com uma bandeira) a adultos e crianças do Brasil e dos Estados Unidos identificaram que a maioria dos pesquisados, especialmente no Brasil, assumiram uma postura moralizante em relação a essas questões. Para os brasileiros os juízos morais foram mais preditos por reações afetivas que por avaliações de nocividade.

Percebemos que as diferentes compreensões das pessoas são influenciadas por informações e variáveis contextuais da vida cotidiana, pelas emoções, e aspectos culturais que interferem nas avaliações que as pessoas produzem, ou seja, os julgamentos morais são heterogêneos e dependentes do contexto. Essas informações reforçam que uma abordagem para a educação moral deve ter em consideração as contradições e controvérsias com as quais os indivíduos lidam no dia a dia.

As distinções que são feitas entre moralidade e convenção social têm sido sustentadas por resultados de mais de cinquenta estudos desenvolvidos desde 1975. Contudo, apesar das divergências as distinções entre moralidade e convenção social têm sido sustentadas por inúmeros estudos realizados em diversos países, dentre eles o Brasil (NUCCI; CAMINO; SAPIRO, 1996).

\subsection{Teorias morais na filosofia}

Como as decisões morais são inevitáveis, as teorias morais constituem uma forma de análise ponderada do modo como nós podemos justificar essas decisões. A esse respeito, não há uma única teoria moral universalmente aceita para a tomada de decisão relacionada a conflitos morais. No entanto, teorias morais podem ser úteis como diretrizes para o 
desenvolvimento do raciocínio moral por proporcionar uma estrutura com alternativas para serem analisadas, esclarecendo valores e justificando a tomada de decisão.

As ciências podem fornecer dados importantes para nos ajudar a fazer melhores escolhas morais, mas por si só não nos diz o que devemos fazer. A ciência pode fornecer uma explicação para os fatos, mas a moral fornece razões acerca de como devemos agir. Assim, pode-se dizer que só porque algo é cientifica ou tecnologicamente possível, não significa que seja moral fazê-lo. Por exemplo, a clonagem reprodutiva é possível do ponto de vista científico, entretanto, deve-se considerar se é moralmente aceitável ou não.

A seguir apresentaremos as teorias morais que utilizaremos como referencial teórico deste trabalho. A seleção que segue somente pretende ressaltar os aspectos da ética filosófica cuja forte tradição histórica as tenha incorporado e cujo conhecimento é indispensável para melhor entender os argumentos atualmente utilizados na sociedade contemporânea. São elas: a) a teoria utilitarista; b) a teoria deontológica; e c) a ética das virtudes ou do carácter moral.

\subsubsection{Virtudes éticas}

As virtudes ocuparam um espaço privilegiado na filosofia moral clássica e cristã. As éticas aristotélica e tomista são éticas da virtude. O conceito de virtude teve sua origem na filosofia de Sócrates, Platão e Aristóteles. Aristóteles definia as virtudes como hábitos, ou traços permanentes de caráter, pelos quais o homem se faz bom e exerce bem suas funções. Os gregos viam a razão como fonte da sabedoria prática, a vida virtuosa era, portanto, inseparável da razão (FERRER; ÁLVAREZ, 2005).

De acordo com Rachels (2006) com o passar do tempo essa forma de pensar passou a ser negligenciada e com a chegada do cristianismo, novas ideias foram introduzidas. Nesse período os cristãos concebiam Deus como legislador e, portanto, uma vida íntegra só teria sentido na obediência aos mandamentos divinos. Santo Agostinho pensador cristão do século IV teve grande influência nesse processo. Os filósofos medievais incorporaram as virtudes ao contexto da Lei Divina e, dessa forma, as virtudes teológicas da fé, da esperança, da generosidade e da obediência passaram a ocupar um lugar privilegiado.

Persistiu como abordagem dominante na filosofia moral ocidental, pelo menos até o Iluminismo, quando sofreu um eclipse durante o século XIX, tendo ressurgido no final de 1950 na filosofia anglo-americana. A ética das virtudes voltou a ser anunciada no artigo de Elisabeth Anscombe, Filosofia da Moral Moderna em, 1958 publicado na revista acadêmica Philosophy, que cristalizou uma crescente insatisfação com as formas de deontologia e utilitarismo 
prevalecentes. Até então, ninguém tinha prestado atenção em temas que sempre figuram, como: as próprias virtudes, motivos e caráter moral, educação moral, sabedoria ou discernimento moral, amizade e relações familiares, no conceito de felicidade, no papel das emoções em nossa vida moral e nas questões de importância fundamental como: "que tipo de pessoa que eu deveria ser" e "como devemos viver". (HURSTHOUSE, 2013).

A filosofia moral contemporânea também conheceu um renascer da ética das virtudes por meio de Alasdair MacIntyre em sua obra intitulada After Virtue publicada em 1981, que consistiu na reelaboração crítica da visão ético-política da tradição aristotélico-tomista (FERRER; ÁLVAREZ, 2005).

O ressurgimento da ética das virtudes teve um efeito revigorante sobre as outras abordagens, cujos proponentes começaram a abordar esses temas em suas teorias. Qualquer versão moderna da ética das virtudes mostra que as suas raízes estão na antiga filosofia grega pelo emprego de três conceitos dela derivados. Esses são arête (excelência ou virtude), phronesis (sabedoria prática ou moral) e eudaimonia (felicidade) (HURSTHOUSE, 2013).

Nesse contexto, a ética das virtudes torna-se uma abordagem diferente para a questão da moral. Em vez de decidir por uma ação por meio da maximização da felicidade no mundo, ou pelos direitos ou deveres de alguém, a ética da virtude centra-se nas virtudes que devem possuir as pessoas boas.

As virtudes são disposições e hábitos que nos permitem agir de acordo com o maior potencial de nosso caráter e em nome de valores como verdade e beleza, honestidade, coragem, compaixão, generosidade, tolerância, amor, fidelidade, integridade, justiça, autocontrole, e prudência são exemplos de virtudes. Ao lidar com um problema moral usando a teoria da ética das virtudes, poderíamos perguntar: que tipo de pessoa eu quero ser?

\subsubsection{Deontologia}

O desenvolvimento da teoria deontológica se deu no auge do racionalismo e do método científico no século XVIII, período em que a tendência era a universalização do conhecimento, a desautorização das visões particulares submetidas à revisão intersubjetiva e a denúncia dos erros de percepção e raciocínio denominados ideologias por Francis Bacon (1561-1626) (KOTTOW, 1995).

Nesse contexto, era necessário demonstrar que o conhecimento operava segundo regras claras e invariáveis que são inerentes a todo ser humano e estão presentes em cada indivíduo, independente da interação social. Immanuel Kant (1724-1804) sustenta que todo 
conhecimento é produto de um impacto da realidade sobre nossos sentidos e da elaboração intelectual desses estímulos. Não existe conhecimento racional sem percepção, portanto, nosso conhecimento depende de algo externo a nós. Mas tampouco há percepção sem intelecção, sendo a razão uma condição prévia e dada a priori para perceber (KOTTOW, 1995).

A moral de Kant atribui à racionalidade a tarefa de se abrir a um fim prático supremo. Seu questionamento "que devo fazer" direciona para o fato que nem a teologia tradicional, nem a ciência moderna são fundadoras de certezas práticas, conduzindo para um vazio filosófico correspondente a questão dos objetivos fundamentais do uso da razão (CASTILHO, 2013).

A fundação da moral é apresentada inicialmente na obra Fundamentação da metafísica dos costumes (1785), onde o referido autor parte do conceito de boa vontade extraído dos julgamentos do senso comum e chega aos princípios da filosofia moral que são o imperativo categórico e a autonomia da vontade.

Kant inicia a primeira seção de sua obra Fundamentação metafísica dos costumes afirmando: "nem nesse mundo, nem fora dele, nada é possível pensar que possa ser considerado como bom sem limitação a não ser uma só coisa: uma boa vontade" (KANT, 2002, p. 21). A boa vontade é um conceito que reside no bom senso natural e que reconhece no dever a única origem possível de toda ação moral: é virtuoso o indivíduo que pode escolher agir por puro respeito pelo dever.

Em seguida Kant (2002) apresenta o conceito do dever que segundo ele contém em si o de boa vontade. Castilho (2013) coloca que moralmente entendido, o dever é o reconhecimento de uma pressão que se impõe de maneira a priori, pois independe de qualquer outra solicitação e é anterior as preferências das inclinações. A consciência do dever independe de qualquer experiência moral anterior, seja ela de origem social, religiosa ou psicológica.

Em outro momento Kant (2002) afirma que o valor moral da ação não é derivado nem depende do fim, ou seja, se o fim é realizado ou não, esse não influencia na atribuição de valor moral a uma ação. Então, é a representação da lei que determina à vontade, como propõe o autor:

assim, o valor moral da ação não reside no efeito que dela se espera; também não reside em qualquer princípio da ação que precise tomar seu fundamento determinante nesse efeito esperado. Pois todos esses efeitos (o agrado do estado próprio, ou incluso o fomento da felicidade alheia) poderiam seralcançados também por outras causas, e para tal não se precisaria, portanto, de um ser racional, em cuja vontade, e somente nela, se pode encontrar o bem supremo e incondicionado. Por conseguinte, outra coisa não há senão a representação da lei em si mesma, a qual só no ser racional se realiza, enquanto é ela, e não o es perado efeito, o fundamento da vontade, podendo constituir o bem excelente a que chamamos moral, que se faz presente já na própria pessoa que 
age segundo essa lei, mas que não se deve esperar de nenhum efeito da ação. (KANT, 2002, p. 28).

Kant (2002, p. 28-29) apresenta dois termos, máxima e lei, e os diferencia. Máxima seria o "princípio subjetivo do querer", que contém a regra prática que a razão determina de acordo com as condições do sujeito, e "lei prática", princípio objetivo que prescreve um comportamento que todo ser racional deve seguir:

mas qual pode ser essa lei, mesmo sem tomar em consideração o efeito que se espera
dela, tem de determinar à vontade para que esta possa se chamar boa, absolutamente
e sem a menor restrição? Como tenho subtraído a vontade de todos os estímulos que
pudessemafastá-la do cumprimento de uma lei, nada mais resta a não ser a legalidade
universal das ações em geral, essa que deve ser o único princípio da vontade, isto é:
não devo agir de modo que possa desejarque minha máxima deva se converter em lei
universal. Aqui é a mera legalidade em geral (sem tomar como base qualquer lei
destinada a certas ações) o que serve de princípio à vontade, e também o que tem de
he servir como princípio, para que o dever não seja em qualquer parte uma ilusão vã
e conceito quimérico; com isso, equilibra-se perfeitamente a comum razão humana
em seus juízos práticos, e o citado jamais deixa o seu campo de visão. (KANT, 2002,
p. 28-29).

Resumindo, para uma ação possuir valor moral, deve ser determinada pelo dever, cujo valor moral está apoiado não na finalidade que se quer atingir, mas na máxima que determina a ação. Sendo assim, o que serve de princípio à vontade e o dever é a necessidade de agir em conformidade com a lei.

A lei moral constitui para Kant (2002, p. 44) um imperativo, que é "a representação de um princípio objetivo, enquanto seja constitutivo para uma vontade chama-se mandamento (da razão), e a fórmula do mandamento chama-se imperativo”.

Os imperativos expressam a necessidade de agir segundo certas regras. Kant os distinguiu em imperativos hipotéticos, que por sua vez podem ser problemáticos ou técnicos e assertórios ou pragmáticos, e imperativos categóricos. Os imperativos hipotéticos nos quais se formulam as regras de ação para lidar com as coisas (imperativos técnicos) e com o bem-estar (imperativos pragmáticos) encontram-se fora do âmbito da questão da moralidade. O imperativo categórico representa uma ação como necessária por si mesma, sem outra finalidade. Vale ressaltar que somente os imperativos categóricos têm valor moral.

Kant (2002, p. 66) também introduz o termo "autonomia". "Para ele, autonomia é, pois, o fundamento da dignidade da natureza humana e de toda a natureza racional", com isso, demonstra que o homem tem a capacidade de ser livre de tudo que for diferente da razão. Dessa forma, segundo Kant (2002) ser moral é ser autônomo, ou seja, para que uma ação tenha valor moral é necessário que ela seja racionalmente determinada. Logo, o que não se obtém por 
determinação da própria razão, não pode valer como uma lei em uma possível legislação universal.

O contrário da autonomia, a heteronomia ocorre quando razões não racionais, ou seja, leis externas a vontade de cada um, influenciadas por sentimentos, paixões ou pensamentos de outros, e não constitui uma ação moral, sendo assim, tal máxima não tem caráter universal. Espírito Santo (2007, p. 91) explica que o conceito de heteronomia opõe-se ao de autonomia à medida que significa condicionamento, e não um agir conforme a razão: "o sujeito recebe do exterior a lei a que se submete".

Entendemos que em Kant a autonomia é o princípio geral da ação. O sujeito não deve ser influenciado por razões externas à própria razão, como as inclinações, impulsos e sentimentos. O dever é a necessidade de uma ação por respeito à lei, portanto, só resta à vontade obedecer à lei prática, baseada na máxima universal, pois ela é a única determinação da vontade, uma vez que ela é um fato da razão. O valor moral da ação não reside na finalidade que dela se espera, pois, o fundamento da vontade é a representação da lei e não o fim que visa promover. A ética kantiana é a ética do dever, auto coerção da razão, que concilia dever e liberdade.

Assim, segundo Kottow (1995) a máxima moral que governa o reto atuar nasce da racionalidade do homem e se expressa como uma prescrição do dever. Daí o nome deontologia $($ deon $=$ dever $)$. Ainda de acordo com o autor podemos resumir: (1) a moral se determina na origem dos atos e não nos seus fins, predominando assim o dever de atuar mais que a consequência do ato; (2) a inspiração do dever moral é racional; (3) A deontologia respeita a liberdade do ser humano para eleger o caminho moral; e (4) a deontologia dever ser absoluta e universal, confiando que o ato moral se imporá sobre qualquer consideração que desconheça ou lesione os demais seres humanos.

Reiss (2010) aponta que a autonomia e a justiça são provavelmente os mais importantes princípios deontológicos. As pessoas que agem de forma autônoma, são capazes de tomar suas próprias decisões informadas e, em seguida, colocá-las em prática. Autonomia está preocupada com os direitos do indivíduo. A justiça, por sua vez, é interpretada de forma mais ampla. Essencialmente, a justiça está relacionada ao tratamento e a distribuição justa dos recursos e oportunidades.

Muita energia pode ser desperdiçada quando utilitaristas e deontologistas discutem. Há sim pouco ou nenhum terreno comum sobre qual o melhor argumento, embora alguns filósofos apontem que pode não haver uma teoria de direitos e obrigações, sem responsabilidade e avaliação das consequências, e sem referência aos direitos e deveres. A conclusão mais segura 
é que é melhor olhar tanto para as consequências de qualquer curso de ação proposto e as considerações intrínsecas relevantes antes de chegar a uma conclusão ética (REISS, 2010).

Para tomar uma decisão moral usando essa segunda abordagem, então, devemos perguntar: será que a ação vai respeitar os direitos de todos? Ações são erradas na medida em que elas violam os direitos dos indivíduos.

\subsubsection{Utilitarismo}

O utilitarismo (BENTHAM, 1780/1988; MILL, 1861/1957) baseia a moralidade nas consequências de uma ação, sendo ações éticas aquelas que criam o maior bem ou felicidade para o maior número de pessoas.

Embora, a primeira exposição sistemática do utilitarismo tenha sido desenvolvida por Jeremy Bentham (1748-1832), a visão central da teoria de que o comportamento moralmente adequado não deverá prejudicar os outros, mas em vez disso aumentar a felicidade ou a utilidade ocorreu muito mais cedo. Os precursores dos utilitaristas clássicos incluem os moralistas britânicos, Cumberland, Shaftesbury, Hutcheson, Gay e Hume (DRIVER, 2014).

Os utilitaristas clássicos, Jeremy Bentham (1748-1832) e John Stuart Mill (18061873), estavam preocupados com a reforma legal e social. Se alguma coisa pudesse ser identificada como a motivação fundamental para o desenvolvimento do utilitarismo clássico seria o desejo de ver, leis, corruptos inúteis e práticas sociais mudarem. A realização desse objetivo exigia uma teoria ética normativa empregada como uma ferramenta crítica. Qual é a verdade sobre o que torna uma ação ou uma política moralmente boa ou certa? Mas o desenvolvimento da teoria em si também foi influenciado por opiniões fortes sobre o que estava errado na sua sociedade. A convicção de que, algumas leis eram ruins resultou na análise de por que elas eram assim. Bentham (2000) afirmou que o que as tornou inadequadas foi sua falta de utilidade, a sua tendência para levar à infelicidade e miséria sem qualquer felicidade de compensação. O que levou a conclusão de que se uma lei ou uma ação não traz nenhum bem, então não é boa (DRIVER, 2014).

Nesse contexto, Bentham argumentou que há um princípio moral fundamental: “o princípio da utilidade". Esse princípio nos exige que quando tivermos que eleger entre diferentes ações políticas ou sociais, devemos escolher aquela que traga as melhores consequências globais para todos os afetados. Como escreveu em seu livro The Principles of Morals and Legislation (1781): 
o princípio da utilidade é à base do presente trabalho: será adequado, portanto, des de o início dar um explícito e determinado relato do que se entende por is so. Por princípio da utilidade se entende o princípio que se destina a aprovar ou desaprovar qualquer ação, de acordo com a tendência que tenha para aumentar ou diminuir a felicidade da parte cujo interesse está em questão: ou, o que é a mesma coisa em outras palavras, para promover ou para se opor a essa felicidade. (2000, p.14, tradução da autora).

John Stuart Mill discípulo de Benthan chegou a ser o defensor mais importante da teoria moral utilitarista. Em seu livro Utilitarianism (1861) Mill apresenta a ideia principal da teoria:

como fundamento da moral, utilitário ou o princípio da maior felicidade, afirma que ações são corretas na proporção como elas tendem a promover a felicidade, errado, quando elas tendem a produzir o inverso da felicidade. Por felicidade é destinado prazer e a ausência da dor; por infelicidade, dor e a privação de prazer. (MILL, 2001, p. 10, tradução da autora).

O utilitarismo clássico é consequencialista em oposição à deontologia, pois ele considera que a retidão moral depende diretamente das consequências do ato. Então, de acordo com o utilitarismo clássico, o que torna uma ação moralmente errada são seus efeitos futuros sobre as outras pessoas (SINNOTT-ARMSTRONG, 2015).

De acordo com a teoria utilitarista, ao decidir o que fazer, temos que nos perguntar que solução promoveria a maior felicidade para todos os afetados. A moral não tem que ser interpretada como fidelidade a um conjunto de regras, uma vez que se considera que o objetivo da moral é a felicidade dos seres nesse mundo.

Nas últimas décadas apareceu a distinção entre "utilitarismo do ato" que julga os diferentes atos pelas consequências previsíveis e o "utilitarismo da norma" que defende a necessidade de ajustar as ações às regras habituais que já mostraram sua utilidade geral pelas consequências (CORTINA; MARTÍNEZ, 2005). Ambas as formas de utilitarismo defendem a moralidade de uma decisão ao predizer suas consequências. Assim, o utilitarismo é uma filosofia baseada na teleologia ou no consequencialismo, em oposição à abordagem da deontologia kantiana, não consequencialista, baseada no dever.

A forma mais simples para avaliar se curso de uma ação é certo ou errado é considerar suas consequências. Não podemos ignorar as consequências de uma ação antes de decidir se é certa ou não. O utilitarismo é frequentemente usado na análise da relação custo-benefício, mas deve-se usá-lo com cuidado, por causa das famosas armadilhas ao aplicar esse paradigma (POSNER, 2002).

Segundo Reiss (2010) a questão mais profunda a ser considerada é se precisamos levar em conta apenas as consequências na tomada de decisões morais? Há certas ações que são 
moralmente necessárias como: a dizer a verdade, não trair a confiança de alguém independentemente das suas consequências. Há ainda uma verdadeira discussão acadêmica entre os filósofos morais quanto à possibilidade ou não de uma pessoa precisar se basear apenas nas consequências de uma ação para decidir se é moralmente certa ou errada.

O utilitarismo oferece um método relativamente simples para decidir o curso moralmente certo de uma ação. Para descobrir o que devemos fazer utilizando essa teoria moral, primeiro identificamos os vários cursos de ação. Em segundo lugar, determinamos todos os benefícios previsíveis e danos que resultariam de cada curso de ação para todos os afetados. $\mathrm{E}$ terceiro, nós escolhemos o curso de ação que proporciona os maiores benefícios para todos os envolvidos.

Essas três abordagens (virtudes éticas, deontologia e utilitarismo) sugerem que devemos levantar alguns questionamentos ao tentar resolver um problema moral.

- Quais os benefícios e os prejuízos do curso de uma ação, e qual alternativa vai levar a melhores consequências globais?

- Que direitos morais as partes afetadas têm, e qual curso de ação respeita melhor esses direitos?

- Qual curso de uma ação desenvolve virtudes morais?

Essas questões não proporcionam uma solução automática para os problemas morais elas apenas permitem identificar algumas considerações morais importantes.

\subsection{Estudos da moral na Psicologia}

O interesse pelo fenômeno moral se manifesta de maneira crescente em diversos âmbitos da esfera social. Esse fato tem suscitado importantes debates e explicações, isso implica a existência de diversos enfoques psicológicos que concebem a moral a partir de diferentes perspectivas. Neste próximo tópico apresentaremos o modelo intuicionista da psicologia moral.

a) Intuicionis mo social - a afirmação central do modelo intuicionista social é que o julgamento moral é causado por uma intuição moral rápida e, é seguido, quando necessário por um raciocínio moral lento. Buscando esclarecer, a seguir apresentaremos as definições de julgamento, raciocínio moral e intuição.

$\underline{\text { Julgamento moral }}$ 
Julgamentos morais são definidos como avaliações (bom vs. mau) de ações ou caráter de uma pessoa que são feitos em relação a um conjunto de virtudes tidas como obrigatórias por uma cultura ou subcultura (HAIDT, 2001).

Ao contrário de outros julgamentos, os juízos morais têm um caráter especial: Eles são impessoais. Isto é, eles destinam-se a ignorar a identidade das pessoas em causa, de modo que eles devem se aplicar a qualquer pessoa na mesma situação. Se for errado para mim roubar um livro da biblioteca, então é errado para você, também, se você está exatamente na mesma situação. Nossos pais nos ensinam regras morais, porque têm uma boa razão para querer que sigamos essas regras. Como resultado, tornamo-nos comprometidos com elas, possivelmente mais do que a outras regras heurísticas que usamos para julgamentos e decisões (BARON, 2008).

\section{$\underline{\text { Raciocínio moral }}$}

O raciocínio moral pode ser compreendido como um tipo de raciocínio prático direcionado para decidir o que fazer em situações que envolvem a formação de julgamentos sobre o que é moralmente correto (RICHARDSON, 2014).

Segundo Baron (2008) o raciocínio moral é importante na tomada de decisão como um todo, porque a maioria das decisões reais envolvem questões morais, no mínimo, porque afetam outras pessoas. A escolha de um trabalho, por exemplo, pode ser considerada como uma decisão puramente pessoal, mas nós podemos fazer o bem ou mal aos outros, escolhendo diferentes caminhos através de nossa vida profissional. Da mesma forma, as relações pessoais não são realmente tão "pessoais" quando elas envolvem promessas que serão mantidas e quebradas, expectativas de lealdade que são definidas e violadas, e responsabilidades que são cumpridas ou negligenciadas. É claro, que determinadas questões envolvem muito mais a moralidade que outras.

Segundo Haidt (2001) raciocinadores morais diários são, por vezes, como cientistas, que aprendem através da elaboração e teste de hipóteses. Modelos do mundo social são consultados pelos indivíduos ao fazer julgamentos morais (TURIEL, 1983). Uma característica fundamental da comparação do raciocínio moral com o cientista é que o raciocínio moral é um tipo de inferência feita seguindo vários passos, como o levantamento de dados, a análise de provas e, posteriormente a tomada de decisão. Alguns desses passos podem ser realizados inconscientemente e estão sujeitos a preconceitos e erros, mas uma parte fundamental da definição de raciocínio é que ele tem estágios, sendo que alguns deles são realizados de forma consciente. O raciocínio moral pode agora ser definido como uma atividade mental consciente 
que consiste em transformar determinadas informações sobre as pessoas e situações a fim de chegar a um julgamento moral. Dizer que o raciocínio moral é um processo consciente significa que o processo é intencional, esforçado, e controlável e que o indivíduo está consciente do que está acontecendo (BARGH, 1994).

\section{Intuição moral}

Pesquisadores da intuição ressaltam o fato de que um julgamento, solução ou conclusão podem aparecer repentinamente, sem esforço e sem qualquer consciência pela pessoa dos processos mentais que levaram ao resultado (BASTICK, 1982; SIMON, 1992). Deve-se ressaltar que a intuição e o raciocínio destinam-se a captar o contraste entre dois tipos de cognição. A maioria das distinções são de que a intuição ocorre rápida, fácil e automaticamente, de modo que o resultado, não é acessível à consciência, ao passo que o raciocínio ocorre de forma mais lenta, requer algum esforço, e envolve, pelo menos, algumas medidas que são acessíveis à consciência.

Com base em Bastick (1982) e Simon (1992) a intuição moral pode ser definida como o aparecimento repentino de um julgamento moral, incluindo uma valência afetiva (bom-mau, gosto-desgosto), sem qualquer consciência de ter passado por etapas de pesquisa, análise de evidências e inferência de uma conclusão.

1. O elo do julgamento intuitivo: propõe que julgamentos morais aparecem na consciência automaticamente e sem esforço como o resultado de intuições morais. Exemplos: avaliações afetivas.

2. O elo do raciocínio post hoc: o modelo propõe que o raciocínio moral é um processo esforçado, em que uma pessoa procura argumentos que vão apoiar um julgamento já realizado. A partir da consciência de julgamento moral a pessoa inicia uma busca por razões capazes de justificá-lo para si diante de sua bagagem cultural.

3. O elo do raciocínio persuasivo: propõe que o raciocínio moral é produzido e enviado verbalmente para justificar o próprio julgamento moral para os outros. Posições morais têm sempre um componente afetivo, assim, a hipótese de que a persuasão fundamentada não funciona com argumentos logicamente convincentes, mas pelo desencadeamento novas intuições afetivamente carregadas.

4. O elo da persuasão social: as pessoas são altamente sintonizadas ao surgimento de normas de grupo, o modelo que propõe o simples fato de amigos, aliados e conhecidos fazerem um julgamento moral exerce uma influência direta sobre os outros, mesmo que a persuasão 
fundamentada não seja utilizada. Os autores enfatizam o poder que as situações sociais têm sobre crenças, atitudes ou comportamentos das pessoas.

Essas quatro ligações formam o chamado núcleo do modelo intuicionista social. $\mathrm{O}$ núcleo do modelo dá ao raciocínio moral um papel causal no julgamento moral. A hipótese de que as pessoas raramente substituem seus julgamentos intuitivos iniciais porque o raciocínio raramente é usado para questionar as próprias atitudes ou crenças. O modelo intuicionista social admite que a pessoas são capazes de se engajar em raciocínio moral privativo, razão pela qual são incluídas duas maneiras em que raciocínio privativo pode dar forma a julgamentos morais.

5. O elo do julgamento fundamentado: as pessoas podem, por vezes, utilizar a razão para um julgamento, substituindo a sua intuição inicial. Em tais casos, o raciocínio é verdadeiramente causal e não se pode dizer que seja baseado nas emoções. No entanto, tal raciocínio ocorre principalmente em casos em que a intuição inicial é fraca e capacidade de processamento é alta.

6. O elo da reflexão em contexto privado: no decurso do pensamento sobre uma situação, uma pessoa pode espontaneamente ativar novas intuições ou modificar as já existentes por meio da reflexão em torno de um problema. O julgamento final pode ser determinado pela intuição mais forte ou pela escolha das alternativas pela razão ou aplicação consciente de uma regra ou princípio. Esse percurso leva o indivíduo a um diálogo interno consigo mesmo eliminando a necessidade de um parceiro de discurso.

Modelos racionalistas se concentram nas ligações 5 e 6 . No modelo intuic ionista social, ao contrário, consiste principalmente julgamento moral baseado nas ligações de 1 a 4 , embora o modelo permita ligações 5 e 6 .

Outra evidência de que a moralidade pode não ser totalmente devida a avaliações cuidadosamente fundamentadas vem de estudos que demonstram que certos juízos morais recrutam regiões do cérebro associadas com o processamento emocional em vez de cognição controlada (GREENE; HAIDT, 2002; PAXTON; GREENE, 2010).

\subsection{O ensino de Ciências e a moral}

Podemos iniciar esse tópico com um questionamento que com certeza não está sendo colocado pela primeira vez. Por que incorporar a moral no ensino de Ciências? Um estudo que se dedica a defender a introdução da moral no ensino de Ciências se baseia na premissa básica de que a moral possui um papel significativo na ciência e que ignorar esse fato pode mascarar e diminuir a compreensão da verdadeira natureza do empreendimento científico. 
Nosso objetivo é enfatizar o fato de que a ciência como um produto da atividade humana envolve uma grande variedade de escolhas e julgamentos de valor como dito no capítulo 1 , que se relacionam à moral. Contudo, independente da questão relativa à neutralidade científica, acreditamos que a introdução de questões morais no ensino de Ciências deve preparar os estudantes para a tomada de decisão informada sobre os usos da ciência.

De acordo com Goldfarb e Pritchard (2000) a maioria dos estudantes e professores quando questionados sobre a ligação entre ética e ciência, fazem referência a questões relacionadas à fraude e plágio científico. Eles geralmente exibem uma crença de que a ciência é em sua maior parte uma atividade isenta de valores.

Entretanto, o sistema de valores e crenças na ciência e o ensino das Ciências possuem diferentes planos e com níveis de lógica diferentes, como afirma Valente (2000). No primeiro nível está o que se pensa sobre a ciência e o que se pensa sobre a educação; no segundo, estão as crenças sobre a própria ciência, a ordem e a inteligibilidade do mundo; na educação, a escolha do currículo e o valor a atribuir ao ensino das Ciências; num terceiro nível no ensino das Ciências, a seleção dos tópicos considerados mais importantes; num quarto nível, o modo como os conteúdos são ensinados, que por sua vez, refletem os valores da sociedade que são filtrados pelo próprio professor.

Há aproximadamente quatro décadas vem ocorrendo o reconhecimento da importância das QSC no ensino de Ciências, das noções do que significa aprender Ciências e das razões para a sua aprendizagem. Essas noções enfatizam o potencial do ensino de Ciências para o letramento científico que envolve a formação para a cidadania e tomada de decisão responsável. Nesse contexto, deve-se considerar além da compreensão do conhecimento científico, as diversas implicações desse conhecimento como: políicos, ambientais, históricos, sociais, culturais e econômicos e morais. Nessa perspectiva, o conteúdo científico não é isolado do contexto social, mas pode ser visto pelos estudantes como parte de um todo maior.

Assim, a importância de ajudar os estudantes a reconhecerem os limites da ciência, caracterizando-a como "um modo rigoroso de pensar sobre a experiência, mas não o único" e a necessidade de incluir questões de ordem moral e metafísica (VALENTE, 2000, p. 3).

Partindo desses pressupostos as QSC podem auxiliar os estudantes a explorarem os aspectos positivos e negativos do desenvolvimento das novas tecnologias, na análise de dados e na utilização de provas em seus argumentos seja em contextos reais ou hipotéticos. Essas condições tornam o ensino de Ciências mais interessante e mais próximo do cotidiano dos 
estudantes, além da promoção do desenvolvimento de habilidades relacionadas à tomada de decisão em controvérsias que envolvam o raciocínio moral.

Como apresentado neste trabalho muitas são as questões levantadas no contexto do ensino de Ciências sobre qual é a decisão certa ou o que devemos fazer? Mais especificamente, no contexto da biotecnologia, por exemplo, podemos levantar várias questões, como: a utilização de doping genético utilizando a técnica de terapia gênica, por atletas visando maximizar seu potencial seria uma ação certa ou errada? Seria justo com os atletas que não recorrem a esse tipo de solução? A manipulação genética em embriões humanos deve ser permitida? A disponibilização de teste genético pré-natal e o que fazer diante de uma reposta positiva? Deve ser permitido o aborto do feto? A seleção do sexo dos embriões produzidos por meio de inseminação artificial?

Essas são apenas algumas poucas questões levantadas, que devem provocar reflexão sobre o que realmente queremos com o desenvolvimento científico e tecnológico. Evitar o sofrimento e a morte a qualquer custo? Selecionar somente as características desejáveis? Eliminar os menos valorizados pela sociedade? Seria uma forma de eugenia? De determinis mo genético? Isso deve ser permitido? Que riscos à saúde e à privacidade podem resultar do desenvolvimento da biotecnologia? Que questões morais se relacionam a essas tecnologias?

A manipulação genética tem levantado uma série de interrogações sobre os seus possíveis impactos na saúde humana e animal, na preservação da biodiversidade e dos ecossistemas, nas estratégias de desenvolvimento econômico, na reprodução de determinadas práticas sociais e culturais e na definição do tipo de sociedade que queremos. São questionamentos que devemos fazer, haja vista que experienciamos negligências e falta de confiabilidade em relação as tomadas de decisão do segmento político atuante na regulação e controle de tais práticas (FRADE; GAMEIRO, 2008).

Entretanto, essas questões não são marcadas apenas pela controvérsia e incerteza científicas, mas pela necessidade de um debate voltado ao esclarecimento de outras questões como as éticas e socioeconômicas, que escapam à análise de peritos e cientistas e que, por isso, exigem o envolvimento do público, através da participação e da consulta nos processos de tomada de decisão (FRADE; GAMEIRO, 2008).

As QSC trazem consigo uma série de elementos que se relacionam a moral como à privacidade, à discriminação, à desigualdade e à justiça. Nesse contexto, a promoção de discussões de QSC desafia os estudantes a construírem argumentos e perspectivas de análise 
visando a solução dessas questões, convidando-os a participação ativa na discussão de temas, para analisarem suas posições atuais reconhecendo as limitações do próprio raciocínio.

Compreendemos que o desenvolvimento moral não se caracteriza apenas pela internalização de normas e regras da sociedade, mas como um processo no qual os estudantes tornem-se responsáveis pela transformação de sua compreensão da moralidade por meio de processos reflexivos. Esse convite à reflexão deve direcionar os estudantes a levantar questões críticas sobre como esses julgamentos foram elaborados e serem mais autônomos em relação ao pensamento moral. Finalmente, ressalta-se a importância da justificação dos julgamentos morais, para que não sejam simples intuições, mas o resultado de um processo cognitivo mais lento e controlado.

De acordo com Grier e Firestone (1998) para ajudar os estudantes a analisar opções e suas possíveis consequências, devemos usar exemplos relevantes e concretos envolvendo o mundo real. Além disso, como Swanson e Hill (1993) sugerem a capacidade de refletir sobre a própria tomada de decisão moral, ou seja, a metacognição moral também pode ter impacto tanto no raciocínio quanto no comportamento moral.

Oser (1995, p. 10, tradução da autora) aponta que para praticar uma educação moral com vistas à autonomia e à responsabilidade devemos:

(a) estimular o nível imediatamente superior de desenvolvimento moral; (b) sensibilizar as crianças e adolescentes a respeito dos temas morais, por exemplo, temas de cuidado, justiça, verdade, tolerância, etc.; (c) apoiar e fazer possível a conduta pro social; e (d) estabelecer um clima moral positivo no qual «a conduta moral negativa e o assumir riscos» (necessários para aprender, ainda que não sejam um objetivo em si mesmos) possamser experimentados, desenvolvendo por sua vez um sistema interno de valores combinado com o conhecimento do mal.

Jones et al. (2007) desenvolveram um projeto para a educação bioética nas escolas da Nova Zelândia a partir de uma ampla revisão da literatura que forneceu a base para o desenvolvimento de um quadro conceitual de onde surgiram os indicadores de progressão do pensamento ético dentro da ciência e tecnologia.

Como nosso estudo envolve a tomada de decisão sobre conflitos que envolvem a ciência e a tecnologia, utilizaremos os indicadores de progressão do pensamento ético proposto por Jones et al. (2007) como referencial teórico adaptado ao contexto da pesquisa na análise dos dados.

O modelo proposto apresenta níveis de progressão que vão do inicial ao avançado (Figura 2) considerando os seguintes aspectos na tomada de decisão: 
1. considera os níveis individual, nacional ou global;

2. avalia diferentes quadros para uma mesma situação;

3. considera apenas os seres humanos (ética antropocêntrica), os anima is sencientes (ética biocêntrica) ou todo o ecossistema (ética ecocêntrica);

4. aponta consequências imediatas ou a longo prazo;

5. segue regras sociais ou se detém a princípios fundamentados;

6. faz uso do conhecimento tácito, do conhecimento ensinado (explícito) ou pesquisa novos conhecimentos;

7. integra o conhecimento científico a princípios éticos;

8. analisa os fatos de acordo com seus próprios valores ou enfatiza as visões dos outros; e

9. aceita ou crítica o quadro ético. 
Figura 2 - Indicadores de progressão do pensamento ético

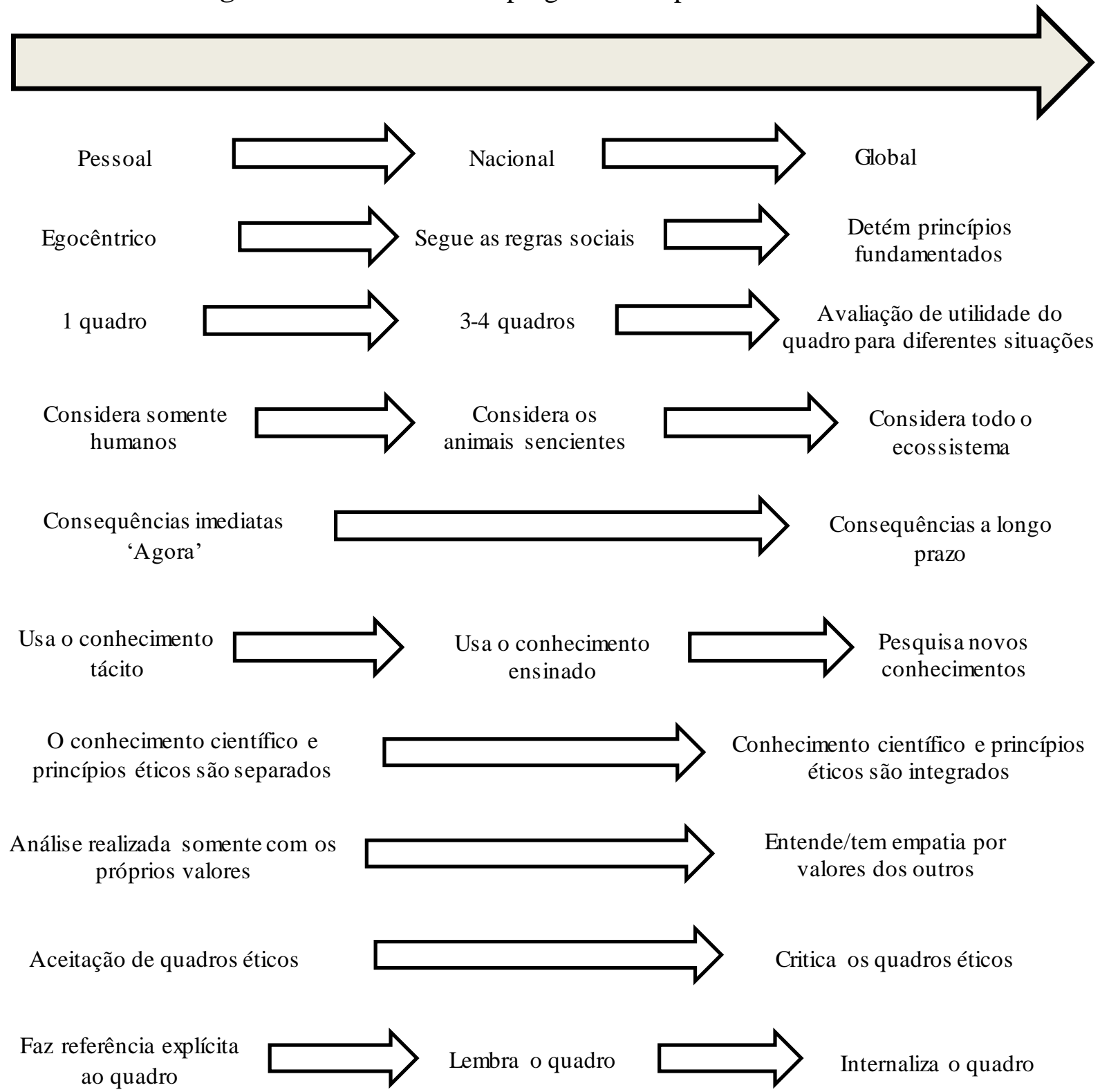

Fonte: Jones et al. (2007, p. 42, tradução da autora).

Razera (2011) organizou um quadro com dois ambientes denominados atmosfera de autonomia moral e atmosfera de heteronomia moral, baseado no conceito de "atmosfera moral" de Kohlberg. A atmosfera de autonomia moral reúne um conjunto de características sociomorais das teorias e elementos provenientes dos diversos discursos da área de Educação em Ciências levantados pelo autor. $\mathrm{Na}$ atmosfera de heteronomia moral são apresentadas características que podem atuar no reforço da heteronomia moral e prejuízos ao ensino de Ciências (Quadro 8). 
Quadro 8-Atmosfera moral em aulas de Ciências

\begin{tabular}{|c|c|}
\hline Atmosfera de autonomia moral & Atmosfera heteronomia moral \\
\hline $\begin{array}{l}\text { - Cultura do sentido (educação do sentido e } \\
\text { expectativa de um futuro modificado para melhor). }\end{array}$ & $\begin{array}{l}\text { - Cultura do tédio (perda de expectativa de um futuro } \\
\text { modificado para melhor). }\end{array}$ \\
\hline - Universalismo ético. & - Relativismo ético. \\
\hline $\begin{array}{l}\text { - Eleição da verdade como valor a ser buscado (não } \\
\text { satisfação com ideias prontas, com fatos não } \\
\text { comprovados, com preconceitos de toda ordem, com } \\
\text { reflexões brumosas e afirmações peremptórias). }\end{array}$ & $\begin{array}{l}\text { - Não eleição da verdade como valor a ser buscado } \\
\text { (satisfação fácil com ideias prontas, com fatos não } \\
\text { comprovados, com preconceitos de toda ordem, com } \\
\text { reflexões brumosas e afirmações peremptórias). }\end{array}$ \\
\hline $\begin{array}{l}\text { - Lacunas do conhecimento são identificadas e } \\
\text { trabalhadas (ênfase não apenas na apropriação de } \\
\text { conhecimentos específicos, mas nas capacidades de } \\
\text { correlação e observação crítica na resolução de } \\
\text { problemas). }\end{array}$ & $\begin{array}{l}\text { - Lacunas do conhecimento não são identificadas e } \\
\text { nem trabalhadas (ênfase na apropriação acrítica de } \\
\text { conhecimentos específicos, sem mobilização das } \\
\text { capacidades de correlação e observação crítica na } \\
\text { resolução de problemas). }\end{array}$ \\
\hline $\begin{array}{l}\text { - Ensino não divorciado de reflexão ética sobre os } \\
\text { conteúdos des envolvidos no interior da ciência. }\end{array}$ & $\begin{array}{l}\text { Ensino com preponderância na descrição } \\
\text { instrumental, teórico ou experimental da ciência, } \\
\text { divorciado de reflexão ética sobre os conteúdos } \\
\text { desenvolvidos no interior da ciência. }\end{array}$ \\
\hline $\begin{array}{l}\text { - Predomínio de discursos normatizadores ou de } \\
\text { modelos edificantes a serem copiados. }\end{array}$ & $\begin{array}{l}\text { - Não predomínio de discursos normatizadores e nem } \\
\text { de modelos edificantes a serem copiados. }\end{array}$ \\
\hline $\begin{array}{l}\text { - Preponderância de cooperação, diálogo e acordo } \\
\text { mútuo. }\end{array}$ & $\begin{array}{l}\text { - Preponderância de repressão, castigo, imposição e } \\
\text { coerção. }\end{array}$ \\
\hline $\begin{array}{l}\text { - Atitudes compatíveis com uma postura ética, que } \\
\text { valoriza a dignidade, a justiça, a igualdade e a } \\
\text { liberdade. }\end{array}$ & $\begin{array}{l}\text { - Atitudes que não valorizam a dignidade, a justiça, a } \\
\text { igualdade e a liberdade. }\end{array}$ \\
\hline $\begin{array}{l}\text { - Possibilidades do aprendizado se expandir para fora } \\
\text { de assuntos puramente científicos, em prol da } \\
\text { autonomia crítica. }\end{array}$ & $\begin{array}{l}\text { - Aprendizagem restrita a assuntos puramente } \\
\text { científicos (desfavorável para a autonomia crítica). }\end{array}$ \\
\hline $\begin{array}{l}\text { - Obediência motivada por controle interno na escolha } \\
\text { consciente de um princípio aceito como válido, mas } \\
\text { mutável se for justo (por exemplo, em prol da vida). }\end{array}$ & $\begin{array}{l}\text { - Obediência motivada por controle externo, por } \\
\text { interesse egocêntrico (por exemplo, medo de castigo). }\end{array}$ \\
\hline $\begin{array}{l}\text { - Entendimento das normas morais como elementos } \\
\text { sociais de regulação entre as pessoas, passíveis de } \\
\text { modificações. }\end{array}$ & $\begin{array}{l}\text { - Entendimento das normas morais como leis sagradas } \\
\text { e não passíveis de modificações. }\end{array}$ \\
\hline $\begin{array}{l}\text { - Relações sociais orientadas pelo acordo racional } \\
\text { sobre as normas e respeito mútuo. }\end{array}$ & $\begin{array}{l}\text { - Relações de obediência passiva sobre as normas, } \\
\text { entendidas como inquestionáveis. }\end{array}$ \\
\hline - Regras e respeito construídos coletivamente. & $\begin{array}{l}\text { - Regras e normas provenientes da coação social } \\
\text { (respeito unilateral - da não autoridade para a } \\
\text { autoridade). }\end{array}$ \\
\hline • Métodos “ativos” de educação moral. & • Métodos “passivos” de educação moral. \\
\hline $\begin{array}{l}\text { - Não traz uma verdade pronta para a criança, nem ela } \\
\text { é coagida a recebê-la de fora. }\end{array}$ & $\begin{array}{l}\text { - Traz uma verdade pronta para a criança, que é } \\
\text { coagida a recebê-la de fora. }\end{array}$ \\
\hline
\end{tabular}


Quadro 8-Atmosfera moral em aulas de Ciências (cont.)

\begin{tabular}{|c|c|}
\hline Atmosfera de autonomia moral & Atmosfera heteronomia moral \\
\hline $\begin{array}{l}\text { - Relevância aos questionamentos dos alunos; não são } \\
\text { interrompidos por explicações reduzidas e unilaterais. }\end{array}$ & $\begin{array}{l}\text { - Não relevância aos questionamentos dos alunos; } \\
\text { predomínio de explicações reduzidas e unilaterais. }\end{array}$ \\
\hline $\begin{array}{l}\text { - Condução da criança ao espírito dos valores sociais } \\
\text { da verdade por meio da colaboração entre os pares e } \\
\text { da prática da discussão organizada. }\end{array}$ & $\begin{array}{l}\text { - Não condução da criança ao espírito dos valores } \\
\text { sociais da verdade; discussão organizada não } \\
\text { praticada. }\end{array}$ \\
\hline $\begin{array}{l}\text { - Não prevalência de procedimentos de recompensa ou } \\
\text { punição. }\end{array}$ & $\begin{array}{l}\text { - Prevalência de procedimentos de recompensa ou } \\
\text { punição. }\end{array}$ \\
\hline $\begin{array}{l}\text { - Orientação teórico-prática do nível pós- } \\
\text { convencional. }\end{array}$ & $\begin{array}{l}\text { - Orientação teórico-prática do nível pré- } \\
\text { convencional. }\end{array}$ \\
\hline $\begin{array}{l}\text { - Uso de argumentos discursivos com pretensões de } \\
\text { validade. }\end{array}$ & $\begin{array}{l}\text { - Uso de argumentos discursivos com pretensões de } \\
\text { poder. }\end{array}$ \\
\hline $\begin{array}{l}\text { - Simetria de participação nas argumentações e } \\
\text { discussões. }\end{array}$ & $\begin{array}{l}\text { - Assimetria de participação nas argumentações e } \\
\text { discussões. }\end{array}$ \\
\hline $\begin{array}{l}\text { - Mobilização do potencial racional para o } \\
\text { entendimento e formação crítica dos alunos. }\end{array}$ & $\begin{array}{l}\text { - Não mobilização do potencial racional para o } \\
\text { entendimento e despreocupação com a formação } \\
\text { crítica dos alunos. }\end{array}$ \\
\hline - Oportunidades para o grupo se autogovernar. & $\begin{array}{l}\text { - Ausência de oportunidades para o grupo de } \\
\text { autogovernar. }\end{array}$ \\
\hline $\begin{array}{l}\text { - Oferecimento ao outro de possibilidade de críticas e } \\
\text { interpretações. }\end{array}$ & $\begin{array}{l}\text { - Ausência de oferecimento ao outro de possibilidade } \\
\text { de críticas e interpretações. }\end{array}$ \\
\hline $\begin{array}{l}\text { - Tentativas permanentes para elevar o nível de } \\
\text { argumentação dos participantes. }\end{array}$ & $\begin{array}{l}\text { - Ausência de tentativas para elevar o nível de } \\
\text { argumentação dos participantes. }\end{array}$ \\
\hline $\begin{array}{l}\text { - Diálogos baseados em princípios de justiça e } \\
\text { solidariedade. }\end{array}$ & $\begin{array}{l}\text { - Ausência de diálogos baseados em princípios de } \\
\text { justiça e solidariedade. }\end{array}$ \\
\hline - Prevalência da ação comunicativa. & - Prevalência da ação instrumental. \\
\hline - Tolerância. & • Intolerância. \\
\hline $\begin{array}{l}\text { - Uso de princípios, procedimentos e conteúdos da } \\
\text { educação em Ciências que possibilitem a reflexão } \\
\text { ética (assuntos sociocientíficos, história e filosofia da } \\
\text { ciência...). }\end{array}$ & $\begin{array}{l}\text { - Não aproveitamento de princípios, procedimentos e } \\
\text { conteúdos da educação em Ciências que possibilitem } \\
\text { a reflexão ética (assuntos sociocientíficos, história e } \\
\text { filosofia da ciência...). }\end{array}$ \\
\hline - Ideia de verdade provisória e processualda ciência. & $\begin{array}{l}\text { - Ideia de verdade absoluta e produto acabado da } \\
\text { ciência. }\end{array}$ \\
\hline $\begin{array}{l}\text { - Respeito aos níveis psicobiológicos do aprendiz e } \\
\text { harmonização com o ensino de Ciências. }\end{array}$ & $\begin{array}{l}\text { - Despreocupações com os níveis psicobiológicos do } \\
\text { aprendiz e não harmonização com o ensino de } \\
\text { Ciências. }\end{array}$ \\
\hline $\begin{array}{l}\text { - Não hierarquização da ciência perante as outras áreas } \\
\text { de conhecimento. }\end{array}$ & $\begin{array}{l}\text { - Hierarquização da ciência perante as outras áreas de } \\
\text { conhecimento. }\end{array}$ \\
\hline
\end{tabular}


Quadro 8 - Atmosfera moral em aulas de Ciências (cont.)

\begin{tabular}{|c|c|}
\hline Atmosfera de autonomia moral & Atmosfera heteronomia moral \\
\hline $\begin{array}{l}\text { - Não difusão da ideia de ciência como uma autoridade } \\
\text { monolítica. }\end{array}$ & $\begin{array}{l}\text { - Difusão da ideia de ciência como uma autoridade } \\
\text { monolítica. }\end{array}$ \\
\hline $\begin{array}{l}\text { - Consciência de que todos os conhecimentos podem } \\
\text { mudar. }\end{array}$ & $\begin{array}{l}\text { - Incons ciência de que todos os conhecimentos podem } \\
\text { mudar. }\end{array}$ \\
\hline $\begin{array}{l}\text { - Compreensão crítica e não relativista sobre os } \\
\text { diferentes tipos de conhecimento. }\end{array}$ & $\begin{array}{l}\text { - Compreensão acrítica e relativista sobre os diferentes } \\
\text { tipos de conhecimento. }\end{array}$ \\
\hline $\begin{array}{l}\text { - Capacidade de avaliação crítica de argumentos, } \\
\text { suposições e conclusões sobre os diferentes tipos de } \\
\text { conhecimento que coexistem com o científico. }\end{array}$ & $\begin{array}{l}\text { - Avaliação acrítica de argumentos, suposições e } \\
\text { conclusões sobre os diferentes tipos de conhecimento } \\
\text { que coexistem com o científico. }\end{array}$ \\
\hline $\begin{array}{l}\text { - Tratamento do conhecimento científico de forma não } \\
\text { autoritária ou brutalizada. }\end{array}$ & $\begin{array}{l}\text { - Tratamento do conhecimento científico de forma } \\
\text { autoritária ou brutalizada. }\end{array}$ \\
\hline $\begin{array}{l}\text { - Conhecimentos divergentes do científico, que os } \\
\text { estudantes trazem consigo de outros lugares, não } \\
\text { rechaçados previamente e nem ignorados com } \\
\text { desdém. }\end{array}$ & $\begin{array}{l}\text { - Conhecimentos divergentes do científico, que os } \\
\text { estudantes trazem consigo de outros lugares, } \\
\text { previamente rechaçados ou ignorados com desdém. }\end{array}$ \\
\hline $\begin{array}{l}\text { - Preocupações e cuidados com o "hablar ciência" } \\
\text { (com a forma e estilo de comunicação). }\end{array}$ & $\begin{array}{l}\text { - Despreocupações e descuidos como "hablar ciência" } \\
\text { (com a forma e estilo de comunicação). }\end{array}$ \\
\hline - Discursos com véus ideológicos de primeiro grau. & - Discursos com véus ideológicos de segundo grau. \\
\hline $\begin{array}{l}\text { - Discursos de nível completo (equilíbrio entre a ética } \\
\text { do cuidado, da justiça e da veracidade, na qual o } \\
\text { professor não somente pressupõe boa vontade, } \\
\text { racionalidade e autonomia em todas as pessoas } \\
\text { envolvidas, mas centra-se na participação real e } \\
\text { decisão comum). }\end{array}$ & $\begin{array}{l}\text { - Discursos de evitação dos problemas ou com } \\
\text { tendências de desvios da responsabilidade sobre a } \\
\text { formação ético-moral. }\end{array}$ \\
\hline $\begin{array}{l}\text { - Mobilização para um posicionamento crítico dos } \\
\text { estudantes sobre os diferentes tipos de "provas" (para } \\
\text { uma predisposição crítica dos estudantes sobre as suas } \\
\text { crenças iniciais). }\end{array}$ & $\begin{array}{l}\text { - "Fé cega" dos estudantes sobre "suas provas" não } \\
\text { trabalhada (continuidade da predisposição acrítica } \\
\text { para a confirmação das crenças iniciais do estudante). }\end{array}$ \\
\hline $\begin{array}{l}\text { - Ensino e aprendizagem orientados para o exercício } \\
\text { de cidadania (preparação para tomadas conscientes de } \\
\text { decisão). }\end{array}$ & $\begin{array}{l}\text { - Ensino e aprendizagem não orientados para o } \\
\text { exercício de cidadania (não preparação para tomadas } \\
\text { conscientes de decisão). }\end{array}$ \\
\hline $\begin{array}{l}\text { - Difusão de imagem de ciência processuale humana } \\
\text { (contextualizada e socialmente não neutra; concepção } \\
\text { não empírico-indutivista e nem ateórica; visão } \\
\text { problemática, histórica, não exclusivamente analítica, } \\
\text { nem acumulativa de conhecimento linear). }\end{array}$ & $\begin{array}{l}\text { - Difusão de imagem ingênua do que é a ciência } \\
\text { (descontextualizada e socialmente neutra; concepção } \\
\text { empírico-indutivista e ateórica; visão aproblemática, } \\
\text { ahistórica, exclusivamente analítica, acumulativa de } \\
\text { conhecimento linear, individualista e elitista). }\end{array}$ \\
\hline $\begin{array}{l}\text { - Ideia de que não existe apenas uma única natureza da } \\
\text { ciência e aulas de Ciências não restritas a um ensino } \\
\text { que apenas considera a natureza da ciência acadêmica } \\
\text { que dominava no passado. }\end{array}$ & $\begin{array}{l}\text { - Ideia de existência de uma única natureza da ciência } \\
\text { e aulas de Ciências restritas a um ensino que apenas } \\
\text { considera a natureza da ciência acadêmica que } \\
\text { dominava no passado. }\end{array}$ \\
\hline
\end{tabular}




\begin{tabular}{|l|l|}
\hline $\begin{array}{l}\text { - Compreensão que ultrapassa a visão internalista da } \\
\text { ciência. }\end{array}$ & $\begin{array}{l}\text {-Compreensão que não ultrapassa a visão internalista } \\
\text { da ciência. }\end{array}$ \\
\hline $\begin{array}{l}\text { - Ideias, princípios, procedimentos e conteúdos em } \\
\text { prol de uma ciência acessível(disciplina de acesso não } \\
\text { restrito a expertos para tomadas de decisão). }\end{array}$ & $\begin{array}{l}\text { - Ideias, princípios, procedimentos e conteúdos em } \\
\text { prol de uma ciência inacessível (disciplina difícil e } \\
\text { acesso restrito a expertos para tomadas de decisão). }\end{array}$ \\
\hline $\begin{array}{l}\text { - Não utilização do conhecimento científico como } \\
\text { instrumento de opressão, coerção ou coação. }\end{array}$ & $\begin{array}{l}\text { - Uso do conhecimento científico como instrumento } \\
\text { de opressão, coerção ou coação. }\end{array}$ \\
\hline $\begin{array}{l}\text { - Finalidades e princípios formativos amplos e não } \\
\text { meramente propedêuticos do ensino de Ciências. }\end{array}$ & $\begin{array}{l}\text { - Finalidades e princípios meramente propedêuticos do } \\
\text { ensino de Ciências (confundindo-se com formação de } \\
\text { cientistas). }\end{array}$ \\
\hline $\begin{array}{l}\text { - Uso de controvérsias de contextos CTSA, por meio } \\
\text { dos seus dilemas e respectivos raciocínios morais, } \\
\text { com objetivos de mobilizar o pensamento crítico e a } \\
\text { evolução da autonomia moral e intelectual. }\end{array}$ & $\begin{array}{l}\text {-Não utilização de temas polêmicos em aula ou uso de } \\
\text { controvérsias de contextos CTSA sem objetivos de } \\
\text { mobilizar o pensamento crítico e o desenvolvimento } \\
\text { da autonomia. }\end{array}$ \\
\hline $\begin{array}{l}\text { - Uso de estratégias que se beneficiam da } \\
\text { heterogeneidade e diversidade em aulas de Ciências, } \\
\text { com objetivos voltados em prol da evolução do } \\
\text { raciocínio moral dos alunos. }\end{array}$ & $\begin{array}{l}\text { Não aproveitamento da heterogeneidade e } \\
\text { diversidade em aulas de Ciências para compor } \\
\text { estratégias em prol da evolução do raciocínio moral } \\
\text { dos alunos. }\end{array}$ \\
\hline $\begin{array}{l}\text { - Os alunos são confrontados com múltiplas } \\
\text { perspectivas de problemas morais que envolvem } \\
\text { pontos de vista e de informação discrepantes e, por } \\
\text { vezes, em contradição com seus próprios pontos de } \\
\text { vista. }\end{array}$ & $\begin{array}{l}\text { - Os alunos não são confrontados com as múltiplas } \\
\text { perspectivas de problemas morais que envolvem } \\
\text { pontos de vista e de informação discrepantes e, por } \\
\text { vezes, em contradição com seus próprios pontos de } \\
\text { vista. }\end{array}$ \\
\hline
\end{tabular}

Fonte: Razera (2011, p. 115-118).

O quadro proposto nos indica um caminho a seguir para a construção de uma atmosfera de autonomia moral nas aulas de Ciências. A construção de um ambiente caracterizado pela atmosfera de autonomia moral apresenta uma configuração que favorece tanto o desenvolvimento moral, como à reflexão, à análise crítica e à construção do conhecimento científico (RAZERA, 2011).

Nesse contexto, apontamos a necessidade de ponderação por parte dos atores envolvidos no processo educativo quanto ao ambiente que temos nas escolas e no ensino de Ciências. Que ambientes temos nas escolas? São ambientes que propiciam a autonomia ou a heteronomia moral? E o ensino de Ciências tem favorecido a construção de que tipo de ambiente? Qual o papel dos professores nesse processo?

Como se vê, o ensino de ética e moral não é algo tão simples e depende de alguns elementos cruciais tais como o ambiente escolar, o uso de estratégias que possam ser utilizad as com o objetivo de mobilizar o pensamento crítico e reflexivo e também a formação do professor. Esse é um fator de extrema importância quando se considera um ensino de Ciências que favoreça o raciocínio reflexivo e crítico e a promoção de um ambiente onde as regras e 
respeito sejam construídos mutuamente, com atitudes compatíveis com uma postura ética, que valorize a dignidade, a justiça e a igualdade. E com possibilidade da expansão do aprendizado para além dos assuntos científicos.

Então, evidenciamos a existência de uma reivindicação para o ensino de ética e moral nas aulas de Ciências. Entretanto, uma questão tem fundamental importância nesse processo, principalmente para os professores, que é "Como ensinar ética nas aulas de Ciências"? Reis (2007, p. 37) também levantou esse questionamento e propôs uma solução que seria por meio da discussão de estudos de caso. De acordo com o autor:

\begin{abstract}
a discussão de estudos de caso sobre as implicações sociais e morais de práticas científicas e tecnológicas controversas na área da biotecnologia revela-se extremamente eficaz na estimulação de interacções sociais na sala de aula, na construção de conhecimentos sobre as temáticas em causa e as inter-relações entre a ciência, a tecnologia e a sociedade e, ainda, no desenvolvimento cognitivo e moral dos alunos [...]. A chave deste progresso reside nos conflitos sócio-cognitivos estabelecidos entre os alunos, ou seja, no confronto interpessoal e intrapessoal de ideias. A discussão dos diferentes pontos de vista facilita a partilha de informações, a construção de conhecimento e a modificação dos raciocínios através da descoberta de inconsistências lógicas. (REIS, 2007, p. 39).
\end{abstract}

Também consideramos que um ensino de Ciências que privilegie o desenvolvimento moral se constitui como tarefa desafiadora para os professores. O desafio é conduzir os estudantes na identificação dos fatos relacionados à determinada questão, reconhecer os dilemas morais subjacentes, identificar os diferentes atores envolvidos, analisar a questão utilizando diferentes quadros morais e tomar a decisão. Os estudantes têm que ser preparados para aplicar os mesmos tipos de reflexão moral e pensamento crítico a situações em que se deparem fora do contexto escolar.

Cabe ressaltar que um ensino de Ciências comprometido com o desenvolvimento moral não deve estar relacionado à inculcação de valores e obrigações morais impostos aos estudantes. Por isso, aponta-se a necessidade de fomentar discussões e debates com QSC apoiadas em princípios morais, ressaltando a justiça, tolerância, equidade, cooperação, respeito pelas diferenças que funcionam como pressupostos da sonhada educação para a cidadania. De acordo com a referência feita no início deste trabalho, leia-se Santos (2008), uma educação científica e tecnológica humanística deve buscar incorporar discussões de valores e reflexões críticas que permitam desvelar a condição existencial humana. 


\subsection{O paradigma biotecnocientífico}

A biotecnociência na atualidade se constituiu um paradigma científico. $\mathrm{O}$ termo paradigma de acordo com Kuhn (1991) se refere a modelos, representações e interpretações de mundo universalmente reconhecidas que fornecem problemas e soluções modelares para a comunidade científica. É por meio dos paradigmas que os cientistas buscam respostas para os problemas colocados pelas ciências.

Schramm (2010, p. 192) afirma que a biotecnociência é um paradigma científico que:

cria as condições de possibilidade e orienta o conhecimento dos fenômenos e processos vivos, assim como as intervenções que visam a seu controle e transformação. Do paradigma biotecnocientífico derivam as biotecnologias, que devem ser consideradas os produtos originados graças à vigência desse paradigma.

Quanto a sua definição Schramm (2010, p. 191) afirma ser um neologismo bio e techne ambos de origem grega e pelo termo cientia, esse já de origem latina que indica:

\footnotetext{
a interação entre sistemas complexos - como são os seres e ambientes vivos - graças ao sistema técnico e de informação que permite agir sobre tais sistemas e aos dispositivos que visam a orientar tais intervenções sobre o mundo da vida (Lebenswelt). O paradigma biotecnocientífico refere-se, em particular, às atividades da medicina e da biologia amplamente entendidas, dos sistemas de informação e comunicação, da biopolítica, e a suas interações.
}

A pesquisa e desenvolvimento tecno-científicos (PDTC) possui como explica Hottois (2003) algumas características: o pragmatismo como quadro filosófico mais apropriado; aspectos e consequências econômicas que suscitam problemas éticos, sociais e políticos. A partir desses problemas levanta-se a questão da responsabilidade que se estende das sociedades nacionale internacional ao gênero humano sobre as condições atuais e futuras de sobrevivência e existência e o seu futuro em longo prazo.

Além disso, a PDTC está em constante interação com o meio em que ela se desenvolve: o meio simbólico que compreende os meios cultural, social, psicológico, institucional dentre outros. No entanto, da interação da PDTC com o meio simbólico decorrem esperanças, fantasmas, angústias, assim como novos modos de vida (HOTTOIS, 2003).

Para Cardoso, Alvarenga e Albuquerque (1999) o paradigma biotecnocientífico nos direciona para a necessidade de uma reavaliação de condutas morais da sociedade frente aos efeitos da bioindústria, que apresenta alguns benefícios frente as expectativas humanas.

Entretanto, a biotecnociência nem sempre é vista como algo benéfico a serviço do bem-estar humano. Para muitos representa ameaça e perigo, gerando uma polarização da 
percepção pública. Desse modo, aparecem dois extremos, os tecnofílicos para os quais qualquer nova tecnologia e biotecnologia é, em princípio, bem-vinda, sem se preocupar com seus eventuais efeitos negativos presentes ou futuros, e os tecnofóbicos, que se preocupam com os efeitos negativos e com os prejuízos às gerações futuras (SCHRAMM, 2010).

Entre os dois extremos, Schramm (2010, p. 194) destaca três vertentes principais.

\begin{abstract}
(a) A primeira é aquela dos adeptos do "princípio de precaução", um princípio híbrido que tem um componente moral e outro, pragmático, pois implica se abster de uma ação quando essa tem alguma probabilidade de ter consequências daninhas para os envolvidos, como poderia ser o caso do uso precipitado e incauto de uma determinada biotecnologia, como a transgenia aplicada ao humano [...]. (b) A segunda posição é aquela defendida pelos adeptos do "princípio de responsabilidade", de acordo com uma proposta inicial de Hans Jonas de 1979, que se preocupa com o futuro da espécie humana e com o impacto das ações humanas sobre os processos naturais e sociais, considerados cada vez mais ameaçados e ameaçadores, is to é, "em risco" e "de risco" [...]. [...] Em particular, esse finalismo intrínseco pode implicar que tudo aquilo que é natural seria em princípio bom, e a biotecnociência, na medida em que ela afetaria tal finalismo, algo reprovável, embora Jonas admita que, sem os progressos da ciência, nossa qualidade de vida seria provavelmente e sensivelmente pior. (c) A terceira posição tenta evitar as objeções às posições anteriores e considera que a biotecnociência pode ser, sob determinadas condições, benéfica para os humanos presentes e futuros, podendo até ser um meio ao serviço dos ideais morais e políticos de justiça, igualdade e emancipação, desde que as escolhas de civilização sejam debatidas livre e publicamente, para se chegar a acordos razoáveis.
\end{abstract}

Hottois (2009) afirma que com exceção a alguns filósofos existe uma grande convergência de intelectuais voltados ao que ele denominou de "naturalismo conservadorista", dentre eles são citados: Francis Fukuyama, Jürgen Habermas e Hans Jonas. O naturalis mo conservadorista está de acordo com o seguinte postulado:

\begin{abstract}
existe uma "natureza humana" e ela é exposta ao perigo pelas tecnociências biogenéticas; só são legitimas as intervenções e manipulações simbólico-linguísticas sobre essa natureza humana por que o homem é, por natureza (ou por essência), o ser vivo "falante (pensante); " as raras intervenções tecnofísicas eventualmente aceitáveis devem ter uma intenção e uma eficácia exclusivamente terapêuticas. A natureza humana e - com uma insistência mínima segundo os filósofos - a natureza terrestre devem ser fundamentalmente protegidas e preservadas, de igual forma. (HOTTOIS, 2009, p. 116)
\end{abstract}

Nesse sentido, percebeu-se que o naturalismo conservadorista apontado por Hottois (2009) é uma forma de tecnofobia, pois apresenta uma reação negativa diante das tecnociências em interação com os ambientes naturais e sociais. Hottois (2009, p. p. 129-130) tece críticas a essa forma de naturalismo, apontando principalmente a recusa das potencialidades emancipatórias que a biotenociência pode trazer para a humanidade e aponta à necessidade de identificação das esferas de maior responsabilidade onde o poder e a força prevalecem sobre 
outras considerações e interesses. Essas esferas são as hierarquias políticas, econômicas e financeiras.

A seguir serão apresentados os procedimentos investigativos a partir da caracterização da abordagem metodológica utilizada, dos instrumentos utilizados para a coleta de dados e realização das análises 


\section{PROCEDIMENTOS INVESTIGATIVOS}

Neste capítulo serão apresentados os procedimentos investigativos desta pesquisa. Para tanto, serão destacadas as questões de pesquisa, o contexto do seu desenvolvimento, os instrumentos utilizados na construção dos dados e sua análise. Inicialmente, a conceitualização de pesquisa participante será revisada.

\subsection{Abordagem metodológica da investigação}

Quanto ao objetivo esta pesquisa pode ser considerada um estudo descritivo com abordagem quanti-qualitativa, a estratégia utilizada foi pesquisa participante. A pesquisa participante implica necessariamente a participação, tanto do pesquisador no contexto, grupo ou cultura de estudo, quanto dos sujeitos que estão envolvidos no processo da pesquisa.

A seguir destacaremos os principais pressupostos da pesquisa participante:

a) a participação não somente do pesquisador no grupo, comunidade ou cultura que pretende compreender, mas também a participação efetiva daqueles que forem pesquisados no transcorrer de todo o processo de pesquisa (THIOLLENT, 1986; GAJARDO, 1986; LE BOTERF, 1987);

b) possui caráter aplicado, por ocorrer em in loco, tratando sempre de "situações reais" (LE BOTERF, 1987) e exigir a devolução do conhecimento obtido junto aos grupos com os quais foi desenvolvido o estudo, buscando uma transformação da realidade de forma positiva (GAJARDO, 1986; THIOLLENT, 1997).

\subsection{Questões de pesquisa}

O objetivo desta pesquisa foi desenvolver sequências didáticas com a introdução de QSC relativas a dilemas de biotecnologia que envolvem aspectos morais, visando caracterizar implicações pedagógicas para tratar questões morais no ensino de Biologia. Para isso, foram identificados os aspectos morais adotados pelos estudantes relativos às QSC, antes, durante e depois da discussão dos dilemas, como propósito de identificar possíveis indicadores da relação entre abordagem de QSC e aspectos morais.

A partir desse objetivo, estabelecemos as seguintes questões de investigação:

- Que aspectos morais orientam a tomada de decisão dos estudantes em relação à QSC sobre temas de biotecnologia? 
- Esses aspectos morais se alteram ao abordar dilemas morais em QSC relativas à biotecnologia?

- Qual a relação entre conhecimentos científicos específicos de Biologia e o raciocínio moral dos estudantes na tomada de decisão de QSC de biotecnologia?

- Que desafios pedagógicos são enfrentados na introdução de QSC, com o propósito de tratar de questões morais no ensino de Biologia?

- Qual o papel da abordagem de QSC em sala de aula no favorecimento do raciocínio moral dos estudantes?

Para responder a essas questões utilizou-se as etapas que serão descritas a seguir.

\subsection{Etapas da investigação}

A partir das reflexões teóricas desenvolvidas por Silva e Santos (2014) constatou-se que são poucos os estudos realizados na área de ensino de Ciências que envolvem QSC e a moral. Mais escassos ainda, são os que trazem uma proposta pedagógica. Nesse contexto e a partir dos objetivos da pesquisa definimos previamente alguns procedimentos metodológicos.

Em junho de 2014 a pesquisadora foi a campo para a realização da pesquisa. Foram selecionadas duas escolas do projeto OBEDUC/CAPES ${ }^{10}$, em diferentes regiões administrativas (RAs), ambas no Distrito Federal. Foram iniciadas as observações das aulas de Biologia do primeiro e terceiros anos do EM e durante esse período foi percebida uma insegurança dos professores para o desenvolvimento dos conteúdos e realização das discussões. Em suas falas os professores alegavam que perderiam muito tempo com essa atividade e que isso atrasaria o cronograma de aulas, cabe ressaltar que a sequência de ensino inicial tinha a previsão de utilização de apenas cinco aulas.

Em setembro do mesmo ano após o exame de qualificação por sugestão da comissão examinadora, foi selecionada apenas uma escola. Em sequência foi sugerida pelos professores de Biologia dessa escola a realização de uma oficina no período vespertino, já que nesse período os estudantes teriam disponibilidade para participarem das atividades. A partir desse momento foi elaborada uma proposta de oficina e selecionadas as turmas de $3^{\circ}$ ano do EM para a participação. Foram selecionadas as turmas de $3^{\circ}$ ano elo fato das mesmas já terem estudado os

\footnotetext{
10 O projeto OBEDUC teve início em 2012, envolveu diferentes universidades brasileiras, dentre elas a UnB e teve por objetivo analis ar processos colaborativos de desenvolvimento de atividades curriculares paut adas nas noções de situação-problema, interdisciplinaridade e contextualização.
} 
conteúdos relacionados aos temas da oficina como: DNA (estrutura e replicação), RNA (estrutura e transcrição) além de tradução e genética.

Os estudantes foram convidados pela pesquisadora, pela professora de Biologia e pelo vice-diretor da escola. Entretanto, mesmo com os convites a oficina não teve um número suficiente de participantes para sua realização, pois, compareceram somente duas estudantes.

Diante dessa situação, um professor de Química que estava atuando no componente curricular Parte Diversificada (PD) ofereceu suas aulas para a realização da oficina. Então, surge mais um complicador: o fator tempo. Com as diversas tentativas de realização da oficina no turno contrário, já estávamos no mês de novembro faltando apenas um mês para o término do ano letivo. Dessa feita, a pesquisa iniciada passou a ser caracterizada como um estudo piloto, que visou o treinamento de habilidades do pesquisador no processo de coleta de dados.

Efetivamente a coleta de dados teve início em março de 2015, após acordo prévio com o professor de Química responsável pelo componente curricular PD. Logo de início foram realizadas entrevistas e aplicado um questionário aberto. $\mathrm{O}$ uso desses instrumentos teve como objetivo caracterizar o perfil dos sujeitos da investigação quanto ao: conhecimento científico em relação aos temas que seriam desenvolvidos na oficina e se eles concordavam ou não com o uso das aplicações da biotecnologia apresentadas. Essa etapa foi realizada nas duas primeiras semanas do mês de março. Depois disso, teve início a oficina que se encerrou em 16 de dezembro de 2015.

\subsection{Contexto e participantes}

Neste tópico apresentaremos uma caracterização da escola, das turmas que participaram do estudo e das aulas ministradas.

\subsubsection{Escola}

O estudo foi realizado em uma escola de EM da rede pública do Distrito Federal para a seleção da escola estudada, utilizou-se os seguintes critérios: 1) pertencer ao sistema público de ensino do Distrito Federal; 2) fazer parte do projeto OBEDUC/CAPES; e 3) ter interesse em participar da pesquisa. Esses critérios foram estabelecidos em função dos objetivos do estudo e da necessidade de pesquisas que pudessem contribuir para o aprimoramento da educação pública.

A escola que participou da pesquisa situa-se em uma região administrativa (RA) Cruzeiro do Distrito Federal inaugurada no início da década de 1970. A clientela atendida, de 
acordo com a diretoria da escola, estava composta, na sua maioria, por estudantes provenientes da comunidade. Na época do estudo, a escola atendia uma média de 900 estudantes, distribuídos em dois turnos (matutino e noturno), sendo 15 turmas de EM, assim distribuídas: seis turmas de $1^{\circ}$ ano, cinco de $2^{\circ}$ ano e quatro de $3^{\circ}$ ano. No noturno a escola funcionava com 15 turmas de Educação de Jovens e Adultos (EJA). O turno matutino funciona das 7 h00 às $12 \mathrm{~h} 00$ e o noturno das $19 \mathrm{~h} 00$ às $23 \mathrm{~h} 00$. A maioria das turmas atendia entre 30 e 35 estudantes. No período vespertino a escola funcionava com projetos: horta, tae-kwon-do, e alguns projetos no laboratório de química.

A gestão da escola é conduzida por um diretor e vice-diretor. A equipe pedagógica era composta por 50 professores, sendo nove readaptados, dois orientadores educacionais, quatro supervisores pedagógicos e quatro coordenadores pedagógicos. Além da equipe pedagógica, a escola contava com um secretário escolar, seis funcionários de serviços gerais e dois porteiros.

O trabalho da escola seguia uma rotina pré-estabelecida composta por atividades acadêmicas que tinham como objetivo abordar os conteúdos estabelecidos para as disciplinas do EM. A escola realizava outras programações como passeios pedagógicos e de lazer, bem como atividades pedagógicas coletivas (feira de ciências, feira cultural, dia do estudante). Todas essas atividades eram organizadas pela direção e pela equipe pedagógica.

\subsubsection{Turmas analisadas}

Foram selecionadas para participação no estudo cinco turmas do $2^{\circ}$ ano do EM (Tabela 3). A seleção das turmas que participaram do estudo foi feita pelo professor que cedeu as aulas para a realização da oficina. O critério indicado pelo professor foi a preparação dos estudantes para o $3^{\circ}$ ano com conteúdos relacionados a genética, essas turmas tinham apenas uma aula de PD por semana.

Tabela 3 - Frequência de estudantes matriculados por turma

\begin{tabular}{cc}
\hline Turmas & Número de estudantes \\
\hline $2 \mathrm{~A}$ & 34 \\
\hline $2 \mathrm{~B}$ & 36 \\
\hline $2 \mathrm{C}$ & 34 \\
\hline $2 \mathrm{D}$ & 30 \\
\hline $2 \mathrm{E}$ & 35 \\
\hline Total & 169 \\
\hline
\end{tabular}

Fonte: elaboração da autora. 
No início do ano foram matriculados 169 estudantes no $2^{\circ}$ ano do EM (total das turmas sem contar com as transferências e desistências). Entretanto, a população do estudo foi constituída no total por 79 estudantes que responderam aos instrumentos aplicados em sala de aula.

\subsubsection{Aulas ministradas}

Para este estudo foi elaborada uma SD destinada aos temas da biotecnologia (transgênicos, células-tronco e clonagem terapêutica e reprodutiva). Além de apresentar os conteúdos científicos relacionados a esses temas como, por exemplo: DNA, RNA, replicação, transcrição, tradução, tecnologia do DNA recombinante, dentre outros. Essa sequência também foi desenvolvida com a intenção de introduzir QSC sobre os temas estudados. A SD foi realizada ao longo de 26 aulas de 50 minutos cada. Segue-se o quadro 9, com a estrutura da SD e o modo como os conteúdos foram distribuídos.

Quadro 9-Conteúdo programático da sequência didática utilizada na coleta de dados

\begin{tabular}{|c|c|}
\hline Encontro & Conteúdo/Ati vi dade \\
\hline \multicolumn{2}{|r|}{ Módulo 1 - Revisão de conceitos e processos } \\
\hline 01 & DNA: estrutura \\
\hline 02 & DNA: replicação \\
\hline 03 & RNA estrutura \\
\hline 04 & RNA transcrição \\
\hline 05 & Tradução \\
\hline 06 & Tradução \\
\hline \multicolumn{2}{|r|}{ Módulo 2 - Introdução a biotecnologia } \\
\hline 07 & $\begin{array}{l}\text { A biotecnologia e suas aplicações apresentação de vídeo de 9minutos e } 48 \text { segundos } \\
\text { https://www.youtube.com/watch?v=bNE8Cy YF0q0 }\end{array}$ \\
\hline 08 & Tecnologia do DNA recombinante \\
\hline \multicolumn{2}{|r|}{ Módulo 3-Organismos transgênicos } \\
\hline 09 & O que são organismos geneticamente modificados? \\
\hline 10 & Plantas transgênicas \\
\hline 11 & Animais transgênicos \\
\hline 12 & Implicações pessoais, sociais, econômicas e ambientais do uso dos trans gênicos (Quadro moral) \\
\hline 13 & $\begin{array}{l}\text { Apresentação de reportagem sobre "10 anos de transgênicos no Brasil" } 22 \text { minutos e } 40 \text { segundos } \\
\text { http://www.youtube.com/watch?v=DREx7do3TRA }\end{array}$ \\
\hline 14 & Discussão de QSC sobre milho trans gênico \\
\hline 15 & Aplicação de QSC escrita sobre milho e salmão transgênico \\
\hline & Módulo 4-Células-tronco \\
\hline
\end{tabular}


Quadro 9-Conteúdo programático da sequência didática utilizada na coleta de dados (cont.)

\begin{tabular}{|c|c|}
\hline Encontro & Conteúdo/Ati vidade \\
\hline \multirow[t]{2}{*}{16} & Células-tronco - o que são? \\
\hline & Células-tronco multipotentes \\
\hline 17 & Células-tronco embrionárias \\
\hline 18 & Reprogramação celular \\
\hline 19 & Implicações do uso de embriões humanos em pesquisas (Quadro moral) \\
\hline 20 & $\begin{array}{l}\text { Apresentação de vídeo "Células-tronco a chave da regeneração" } 44 \text { minutos } \\
\text { https://www.youtube.com/watch?v=ScEhNEC_-Us }\end{array}$ \\
\hline \multicolumn{2}{|r|}{ Módulo 5 - Clonagem terapêutica e reproduti va } \\
\hline 21 & Clonagem terapêutica \\
\hline 22 & Clonagem reprodutiva $-\mathrm{o}$ caso Dolly \\
\hline 23 & Implicações da clonagem reprodutiva (Quadro moral) \\
\hline 24 & $\begin{array}{l}\text { Apresentação de vídeo sobre "Clonagem animal" de } 24 \text { minutos } \\
\text { https://www.youtube.com/watch?v=ok1QZP5bpFM }\end{array}$ \\
\hline 25 & Discussão de QSC sobre clonagem reprodutiva \\
\hline 26 & $\begin{array}{c}\text { Aplicação de provas do } 4^{\circ} \text { bimestre e aplicação de QSC escrita sobre clonagem reprodutiva e } \\
\text { terapia gênica }\end{array}$ \\
\hline
\end{tabular}

Fonte: elaboração da autora.

No módulo 1 foi realizada uma revisão sobre os temas DNA, RNA, estrutura e processo de replicação e transcrição e tradução. Esses conteúdos estão previstos no currículo do $1^{\circ}$ ano, porém poucos estudantes disseram lembrar ou terem estudado esses conteúdos no ano anterior. Daí a necessidade dessa revisão para o desenvolvimento dos módulos subsequentes.

O módulo 2 foi o momento da introdução à biotecnologia e foi dividido em dois encontros:

$1^{\circ}$ encontro - apresentação de imagens de produtos utilizados no dia a dia como pão, vinho, iogurte e vacinas que são obtidos através de técnicas da biotecnologia. O objetivo dessa apresentação foi contextualizar que a utilização de microrganismos ou parte deles no desenvolvimento de atividades como, por exemplo, a alimentação, já vem sendo desenvolvidas pelo homem há milhares de anos. E que as técnicas modernas da biotecnologia só se desenvolveram a partir do conhecimento da estrutura do DNA que se deu na década de 1950. Para finalizar foi apresentado um vídeo de 9 min e 48 segundos sobre a biotecnologia e suas aplicações.

$2^{\circ}$ encontro - exposição sobre a tecnologia do DNA recombinante destacando que o domínio dessa tecnologia abriu as portas para várias possibilidades na biotecnologia. 
O terceiro módulo foi constituído de sete encontros, onde foi abordado o tema transgênicos.

$1^{\circ}$ encontro - introdução do que vem a ser organismos transgênicos e de como é possível por meio da técnica do DNA recombinante a produção dos mesmos.

$2^{\circ}$ e $3^{\circ}$ encontros - exposição sobre a técnica utilizada para plantas e animais transgênicos.

$4^{\circ}$ encontro - caracterização dos aspectos positivos e negativos dos transgênicos no Brasil (milho, soja e algodão). Considerando aspectos como: saúde humana, economia, política e meio ambiente.

$5^{\circ}$ encontro - apresentação do vídeo "10 anos de transgênicos no Brasil”, sobre quando e como se deu a introdução dos transgênicos no Brasil. As informações foram incorporadas a partir do discurso de agricultores, empresas de produtos orgânicos, dos consumidores e de exrepresentantes da Comissão de Biossegurança do Ministério da Ciência e Tecnologia, fazendo um perfil do que mudou nesses 10 anos de utilização dos transgênicos.

$6^{\circ}$ encontro - realização de uma sessão de discussão a partir da introdução de uma QSC sobre milho transgênico (Apêndice C), com o objetivo de que os estudantes apresentassem e defendessem seus pontos de vista.

$7^{\circ}$ encontro - aplicação da QSC sobre milho transgênico juntamente com uma nova QSC sobre salmão transgênico (Apêndice C) por escrito para que os estudantes respondessem individualmente, devido ao fato da participação de poucos estudantes na discussão.

O quarto módulo foi sobre células-tronco com cinco encontros que serviram como base para a introdução do tema clonagem terapêutica. Nesse módulo apresentou-se a polêmica em torno da utilização das células-tronco no Brasil com a elaboração da lei de Biossegurança em 2005 e a abertura de uma ação de inconstitucionalidade que terminou em 2008, sem modificações na referida lei de Biossegurança. Esse módulo foi concluído com a exibição do vídeo "Células-tronco a chave da regeneração" que trata de pesquisas recentes realizadas no Brasil.

O quinto módulo foi sobre clonagem terapêutica e reprodutiva constituído de cinco encontros.

$1^{\circ}$ encontro - apresentou-se o conteúdo sobre o que é clonagem terapêutica e as consequências envolvidas nesse processo como, por exemplo: possibilidade de novas alternativas terapêuticas, imprevisibilidade de danos/risco, destruição dos embriões gerados como parte do processo e comercialização de células e embriões humanos. 
$2^{\circ}$ encontro - constituiu-se pelo tema clonagem reprodutiva contextualizado pelo caso Dolly.

$3^{\text {o }}$ encontro - apresentou-se as implicações de uma possível clonagem reprodutiva humana com a utilização de um quadro moral.

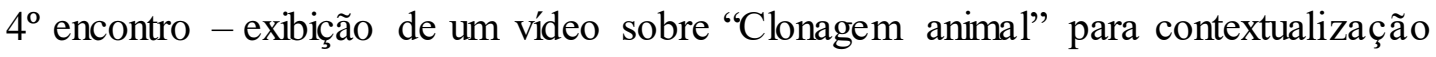
do tema.

$5^{\circ}$ encontro - realização de uma sessão de discussão com a apresentação de uma QSC sobre clonagem reprodutiva (Apêndice D).

$6^{\circ}$ encontro - aplicação da mesma QSC (Apêndice D) juntamente com duas novas QSC sobre terapia gênica (Apêndice E), uma tratando do tema albinismo e outra sobre doping genético para serem redigidas pelos estudantes como proposta de participação. Como não foi possível abordar o tema terapia gênica foi elaborado e apresentado um texto explicativo juntamente com as questões do apêndice E.

Cada um dos módulos foi constituído por três eixos principais, conforme figura 3:

- $1^{\circ}$ eixo - foi constituído pela compreensão do conhecimento científico relativo ao tema específico de cada módulo;

- $2^{\circ}$ eixo - nesse eixo considerou-se a exposição das implicações pessoais, sociais, políticas, econômicas e ambientais relacionadas a cada tema; e

- $\quad 3^{\circ}$ eixo - esse eixo consistiu de um quadro para análise das implicações morais de cada uma das aplicações da biotecnologia com ênfase, nos riscos e benefícios, direitos e deveres e em virtudes como a honestidade, integridade, compaixão etc.

A figura 3 apresenta os três eixos de atuação da professora pesquisadora na sequência didática. 
Figura 3 - Eixos de atuação da professora pesquisadora na sequência didática

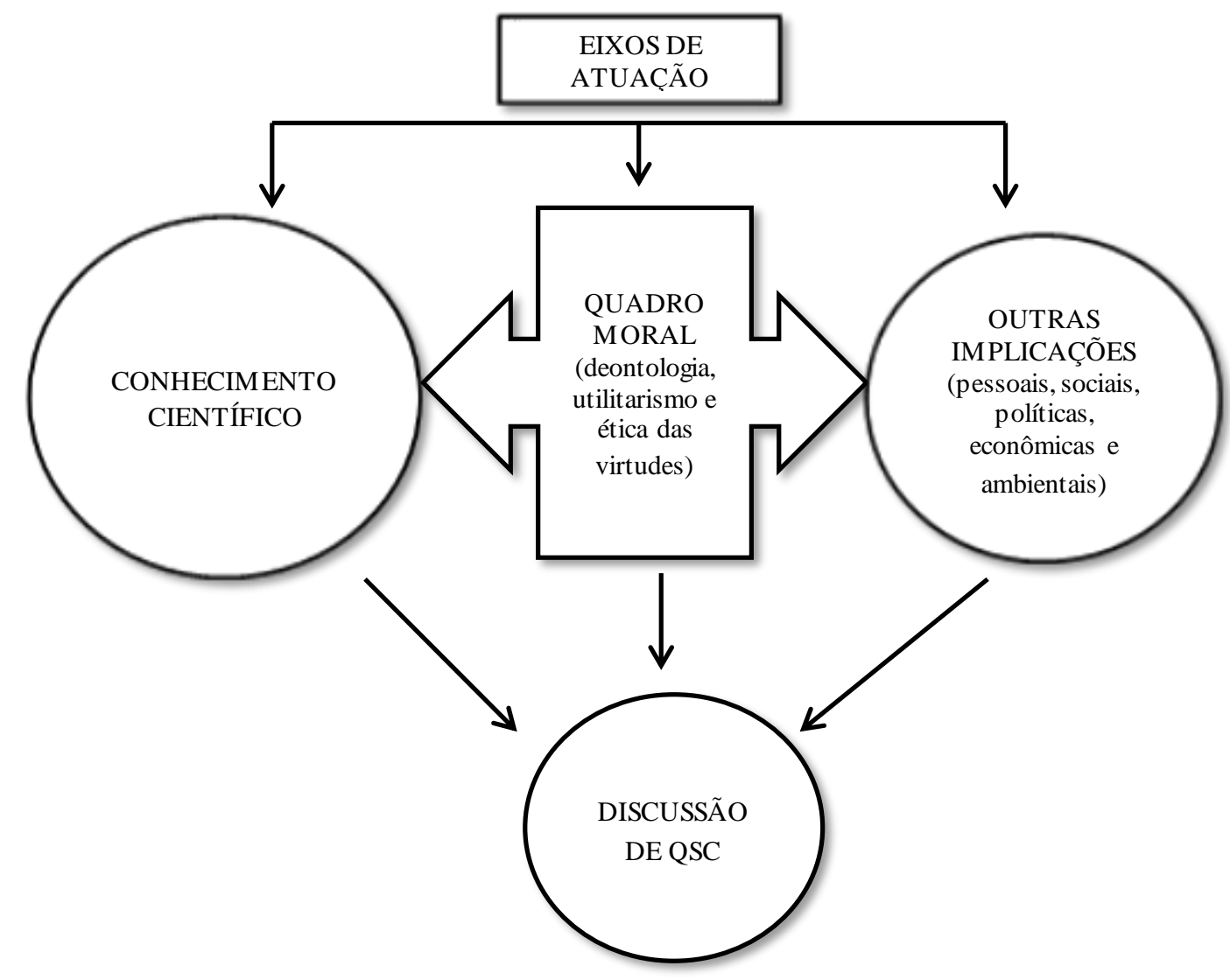

Fonte: elaboração da autora.

Os estudantes foram esclarecidos sobre a pesquisa a ser realizada e convidados a participar da mesma. Os pais e responsáveis receberam uma comunicação por escrito, explicando a pesquisa, assim como, o Termo de Consentimento Livre e Esclarecido (TCLE) (Apêndice B), que foi assinado por aqueles que autorizaram a participação.

Todos os passos e critérios especificados acima foram planejados de acordo com o exigido pelas normas da Ética para Pesquisa com Seres Humanos.

As aulas ministradas ocorriam às segundas-feiras das 10h:30 às $12 \mathrm{~h} 00$ (duas aulas) e às quartas-feiras das 7h:00 as 9h:20 (três aulas), sendo uma aula de 50 minutos para cada turma participante do estudo. A escola funcionava com salas ambientes, assim nas trocas de aula os estudantes que se deslocavam. A sala de aula era espaçosa, com carteira tipo universitária de boa qualidade que ficavam dispostas em fileiras, mas os estudantes as movimentavam para ficarem mais próximos dos pares. Assim, era comum ter grupos de dois ou até três estudantes sentados lado a lado. A média de estudantes frequentes era de aproximadamente 25 a 30 estudantes por turma, com exceção da turma E que em função de grande evasão de estudantes 
na turma, tinha cerca de 15 estudantes frequentes, e por isso, várias carteiras ficavam desocupadas.

O arranjo final das carteiras era, portanto, em forma de fileiras desalinhadas com algumas carteiras dispostas lado a lado. Geralmente os estudantes costumavam sentar nos mesmos lugares. A mesa da professora pesquisadora ficava no lado oposto da porta. Na região central da sala, próxima a sua mesa, ficava a maior parte dos estudantes que habitualmente participavam das aulas. Ao fundo concentravam-se a maioria dos estudantes que manifestavam desinteresse pelas aulas.

A participação dos estudantes nas aulas, em geral, era caracterizada pela existência de três grupos distintos de estudantes: um que participava ativamente, outro que demonstrava interesse pelas aulas e acompanhava as explicações, mesmo sem participar ativamente, e um terceiro grupo que demonstrava desinteresse. O primeiro grupo, constituído de estudantes que evidenciavam interesse pela aula e participavam ativamente, era composto por uma média de cinco estudantes que participavam sistematicamente em todas as aulas, respondendo por mais de uma vez os questionamentos da professora. O segundo grupo, constituído por estudantes que manifestavam interesse sem participar ativamente, que demonstravam estar acompanhando a aula e dirigiam o olhar para a professora pesquisadora. O terceiro grupo de estudantes, a grande maioria em todas as turmas, demonstrava alheamento conversando durante toda a aula.

As aulas na rede pública do Distrito Federal em 2015 tiveram início em 23/02. As atividades do presente estudo iniciaram no mês de março, sendo que nos dias 30/03, 01/04, 06/04 e 08/04 foram realizadas as entrevistas e aplicados os questionários.

A seguir o quadro 10 relaciona o cronograma de atividades desenvolvidas paras as turmas $2 \mathrm{C}$ e $2 \mathrm{D}$ cujas aulas ocorriam nas segundas-feiras.

Quadro 10 - Cronograma de atividades das turmas 2C e 2D com aulas na segundafeira

\begin{tabular}{|c|c|c|c|}
\hline Aula & Data & Conteúdo/Ati vidade & \multirow{2}{*}{ Tema } \\
\hline 01 & $13 / 04$ & Revisão de conceitos e \\
processos
\end{tabular}




\begin{tabular}{|c|c|c|c|}
\hline 07 & $01 / 06$ & $\begin{array}{l}\text { A biotecnologia e suas aplicações } \\
\text { apresentação de vídeo de 9minutos e } 48 \\
\text { segundos } \\
\text { https://www.youtube.com/watch?v=bNE } \\
\text { 8CyYF0q0 }\end{array}$ & \multirow[t]{2}{*}{ Introdução a biotecnologia } \\
\hline 08 & $08 / 06$ & Tecnologia do DNA recombinante & \\
\hline 09 & $15 / 06$ & $\begin{array}{l}\text { O que são organismos geneticamente } \\
\text { modificados? }\end{array}$ & \multirow[t]{9}{*}{$\begin{array}{l}\text { Organismos geneticamente } \\
\text { modificados }\end{array}$} \\
\hline 10 & $22 / 06$ & Plantas geneticamente modificadas & \\
\hline 11 & $29 / 06$ & Animais geneticamente modificados & \\
\hline \multicolumn{3}{|c|}{ 06/07 Aplicação de provas do $2^{\circ}$ bimestre } & \\
\hline 12 & $13 / 07$ & $\begin{array}{l}\text { Implicações pessoais, sociais, } \\
\text { econômicas e ambientais do uso dos } \\
\text { transgênicos (Quadro moral) }\end{array}$ & \\
\hline \multicolumn{3}{|c|}{ Recesso escolar 18 a 31/07 } & \\
\hline 13 & $03 / 08$ & $\begin{array}{l}\text { Apresentação de reportagem sobre “10 } \\
\text { anos de trans gênicos no Brasil”" } 22 \\
\text { minutos e } 40 \text { segundos } \\
\text { http://www.youtube.com/watch?v=DRE } \\
\text { x7do3TRA }\end{array}$ & \\
\hline 14 & $11 / 08$ & $\begin{array}{l}\text { Discussão de QSC sobre milho } \\
\text { geneticamente modificado }\end{array}$ & \\
\hline 15 & $17 / 08$ & $\begin{array}{l}\text { Aplicação de QSC escrita sobre milho e } \\
\text { salmão geneticamente modificado }\end{array}$ & \\
\hline 16 & $24 / 08$ & $\begin{array}{l}\text { Células-tronco - o que são? } \\
\text { Células-tronco multipotentes }\end{array}$ & \multirow[t]{7}{*}{ Células-tronco } \\
\hline 17 & $31 / 08$ & Células-tronco embrionárias & \\
\hline \multicolumn{3}{|c|}{ 07/09 Feriado Nacional } & \\
\hline 18 & $15 / 09$ & Reprogramação celular & \\
\hline \multicolumn{3}{|c|}{ 23/09 Aplicação de provas do $3^{\circ}$ bimes tre } & \\
\hline 19 & $30 / 09$ & $\begin{array}{c}\text { Implicações do uso de embriões } \\
\text { humanos em pesquisas (Quadro moral) }\end{array}$ & \\
\hline 20 & $07 / 10$ & $\begin{array}{l}\text { Apresentação de vídeo "Células -tronco a } \\
\text { chave da regeneração" } 44 \text { minutos } \\
\text { https://www.youtube.com/watch?v=ScE } \\
\text { hNEC_-Us }\end{array}$ & \\
\hline \multicolumn{4}{|c|}{ 12/10 Feriado Nacional } \\
\hline \multicolumn{4}{|c|}{ Greve dos professores de 15/10 a 10/11 } \\
\hline 21 & $16 / 11$ & Clonagem terapêutica & \multirow{4}{*}{$\begin{array}{l}\text { Clonagem terapêutica e } \\
\text { reprodutiva }\end{array}$} \\
\hline 22 & $23 / 11$ & Clonagem reprodutiva - o caso Dolly & \\
\hline 23 & $30 / 11$ & $\begin{array}{c}\text { Implicações da clonagem reprodutiva } \\
\text { (Quadro moral) }\end{array}$ & \\
\hline 24 & $07 / 12$ & $\begin{array}{l}\text { Apresentação de vídeo sobre "Clonagem } \\
\text { animal" de } 24 \text { minutos }\end{array}$ & \\
\hline
\end{tabular}




\begin{tabular}{|c|c|c|}
\hline & & $\begin{array}{c}\text { https://www.youtube.com/watch?v=ok1 } \\
\text { QZP5bpFM }\end{array}$ \\
\hline 25 & $14 / 12$ & $\begin{array}{c}\text { Discussão de QSC sobre clonagem } \\
\text { reprodutiva }\end{array}$ \\
\hline 26 & $16 / 12$ & $\begin{array}{c}\text { Aplicação de provas do 4º bimestre e } \\
\text { aplicação de QSC escrita sobre clonagem } \\
\text { reprodutiva e terapia gênica }\end{array}$ \\
\hline
\end{tabular}

Fonte: elaboração da autora.

Na sequência o quadro 11 relaciona o cronograma de atividades desenvolvidas paras as turmas $2 \mathrm{~A}, 2 \mathrm{~B}$ e $2 \mathrm{E}$ que tinham aula nas quartas-feiras.

Quadro 11 - Cronograma de atividades das turmas 2A, 2B e 2E com aulas na quarta-feira

\begin{tabular}{|c|c|c|c|}
\hline Aula & Data & Conteúdo/Ati vi dade & Tema \\
\hline 01 & $15 / 04$ & DNA: estrutura & \multirow{7}{*}{$\begin{array}{l}\text { Revisão de conceitos e } \\
\text { processos }\end{array}$} \\
\hline 02 & $22 / 04$ & DNA: replicação & \\
\hline \multicolumn{3}{|c|}{ 29/04 Aplicação de provas do $1^{\circ}$ bimestre } & \\
\hline 03 & $06 / 05$ & RNA estrutura & \\
\hline 04 & $13 / 05$ & RNA transcrição & \\
\hline 05 & $20 / 05$ & Tradução & \\
\hline 06 & $27 / 05$ & Tradução & \\
\hline 07 & 03/06 & $\begin{array}{l}\text { A biotecnologia e suas aplicações } \\
\text { apresentação de vídeo de 9minutos e } 48 \\
\text { segundos } \\
\text { https://www.youtube.com/watch?v=bNE } \\
\text { 8CyYF0q0 }\end{array}$ & \multirow[t]{2}{*}{ Introdução a biotecnologia } \\
\hline 08 & $10 / 06$ & Tecnologia do DNA recombinante & \\
\hline 09 & $17 / 06$ & $\begin{array}{l}\text { O que são organismos geneticamente } \\
\text { modificados? }\end{array}$ & \multirow[t]{8}{*}{$\begin{array}{l}\text { Organismos geneticamente } \\
\text { modificados }\end{array}$} \\
\hline 10 & $24 / 06$ & Plantas geneticamente modificadas & \\
\hline 11 & $01 / 07$ & Animais geneticamente modificados & \\
\hline \multicolumn{3}{|c|}{ 08/07 Aplicação de provas do 2 bimestre } & \\
\hline 12 & $15 / 07$ & $\begin{array}{l}\text { Implicações pessoais, sociais, } \\
\text { econômicas e ambientais do uso dos } \\
\text { transgênicos (Quadro moral) }\end{array}$ & \\
\hline \multicolumn{3}{|c|}{ Recesso escolar 18 a 31/07 } & \\
\hline \multicolumn{3}{|c|}{ 05/08 Conselho de classe } & \\
\hline 13 & $12 / 08$ & $\begin{array}{l}\text { Apresentação de reportagem sobre "10 } \\
\text { anos de transgênicos no Brasil" } 22 \\
\text { minutos e } 40 \text { segundos } \\
\text { http://www.youtube.com/watch?v=DRE } \\
\text { x7do3TRA }\end{array}$ & \\
\hline
\end{tabular}




\begin{tabular}{|c|c|c|c|}
\hline 14 & $19 / 08$ & $\begin{array}{l}\text { Discussão de QSC sobre milho } \\
\text { geneticamente modificado }\end{array}$ & \\
\hline 15 & $26 / 08$ & $\begin{array}{l}\text { Aplicação de QSC escrita sobre milho e } \\
\text { salmão geneticamente modificado }\end{array}$ & \\
\hline 16 & $02 / 09$ & $\begin{array}{l}\text { Células-tronco - o que são? } \\
\text { Células-tronco multipotentes }\end{array}$ & \multirow[t]{6}{*}{ Células-tronco } \\
\hline 17 & $09 / 09$ & Células-tronco embrionárias & \\
\hline 18 & $16 / 09$ & Reprogramação celular & \\
\hline \multicolumn{3}{|c|}{ 23/09 Aplicação de provas do $3^{\circ}$ bimestre } & \\
\hline 19 & $30 / 09$ & $\begin{array}{c}\text { Implicações do uso de embriões } \\
\text { humanos em pesquisas (Quadro moral) }\end{array}$ & \\
\hline 20 & $07 / 10$ & $\begin{array}{l}\text { Apresentação de vídeo "Células -tronco a } \\
\text { chave da regeneração" } 44 \text { minutos } \\
\text { https://www.youtube.com/watch?v=ScE } \\
\text { hNEC_-Us }\end{array}$ & \\
\hline \multicolumn{4}{|c|}{ 14/10 Reunião de pais } \\
\hline \multicolumn{4}{|c|}{ Greve dos professores de $15 / 10$ a 10/11 } \\
\hline 21 & $11 / 11$ & Clonagem terapêutica & \multirow{6}{*}{$\begin{array}{l}\text { Clonagem terapêutica e } \\
\text { reprodutiva }\end{array}$} \\
\hline 22 & $18 / 11$ & Clonagem reprodutiva - o caso Dolly & \\
\hline 23 & $25 / 11$ & $\begin{array}{c}\text { Implicações da clonagem reprodutiva } \\
\text { (Quadro moral) }\end{array}$ & \\
\hline 24 & $02 / 12$ & $\begin{array}{l}\text { Apresentação de vídeo sobre "Clonagem } \\
\text { animal" de } 24 \text { minutos } \\
\text { https://www.youtube.com/watch?v=ok1 } \\
\text { QZP5bpFM }\end{array}$ & \\
\hline 25 & $09 / 12$ & $\begin{array}{c}\text { Discussão de QSC sobre clonagem } \\
\text { reprodutiva }\end{array}$ & \\
\hline 26 & $16 / 12$ & $\begin{array}{l}\text { Aplicação de QSC escrita sobre } \\
\text { clonagem reprodutiva e terapia gênica }\end{array}$ & \\
\hline
\end{tabular}

Fonte: elaboração da autora.

As aulas da professora pesquisadora eram caracterizadas, por uma exposição oral, algumas vezes com a intervenção dos estudantes por meio de perguntas, para o esclarecimento de dúvidas. Em todas as aulas a professora utilizava projetor de slides (data show) para a exposição de imagens. A professora pesquisadora, também usava o quadro branco e pincel com esquemas sintéticos do que estava explicando.

\subsection{Procedimentos metodológicos}

De forma geral, a pesquisa contou com a elaboração e utilização de:

(1) memória de campo;

(2) roteiro para a realização de entrevista semiestruturada; 
(3) questionário com questões abertas;

(4) QSC sobre transgênicos, clonagem reprodutiva e terapia gênica; e

(5) roteiro para as sessões de discussão sobre milho transgênico e clonagem reprodutiva.

Esses instrumentos serão explicitados, de forma mais detalhada, a seguir.

\subsubsection{Roteiro para a entrevista individual com os estudantes}

A entrevista individual semiestruturada foi realizada antes do início do desenvolvimento da sequência didática (SD). As entrevistas tiveram uma duração média de cinco minutos. Para a obtenção dos depoimentos, foi solicitado aos sujeitos de pesquisa que respondessem as seguintes questões norteadoras: (1) O que você entende por: a) Clonagem? Você é contra ou a favor? Explique? b) Utilização de células-tronco? Você é contra ou a favor? Explique? c) Terapia gênica? Você é contra ou a favor? Explique? d) Transgênicos? Você é contra ou a favor? Explique?

\subsubsection{Questionário}

A aplicação do questionário foi realizada antes do início da SD. O questionário foi constituído por quatro questões abertas. Você estaria disposto a: 1) fazer um teste genético do feto durante a sua gravidez ou da sua parceira? Justifique sua resposta. 2) fazer um teste genético para descobrir se você corre risco de desenvolver uma doença grave no futuro? Justifique sua resposta. 3) utilizar na sua alimentação um alimento transgênico (alimento geneticamente modificado)? Justifique sua resposta. 4) se fosse portador de uma doença genética você se submeteria a um tratamento para corrigir seus genes (terapia genética)? Justifique sua resposta.

Todos os roteiros foram elaborados após a inserção da pesquisadora no contexto da instituição que permitiu a realização da pesquisa, e a partir dos objetivos da mesma.

\subsubsection{Questões sociocientíficas}

Neste estudo foram utilizadas quatro QSC duas visando promover as discussões em sala de aula (milho transgênico e clonagem reprodutiva) e outras três QSC para serem redigidas pelos estudantes (salmão transgênico, albinismo e doping genético). 


\subsubsection{Roteiro para as sessões de discussão em sala de aula}

Para a realização das discussões em sala de aula utilizou-se dois roteiros constituídos por um conjunto de perguntas relacionadas às QSC milho transgênico (Apêndice F) e clonagem reprodutiva (Apêndice G). Esses roteiros tiveram como objetivo suscitar a avaliação dos estudantes sobre as questões morais relacionadas ao tema discutido, além de nortear a discussão.

\subsection{Construção dos dados}

Neste estudo utilizou-se três filmadoras Samsung, dois gravadores SONY e um computador. As entrevistas individuais com os estudantes foram registradas com os gravadores e as discussões com as câmeras filmadoras.

Antes da realização das filmagens fez-se alguns testes para identificação das melhores posições das câmeras para as atividades propostas na SD. O posicionamento escolhido é apresentado na figura 4.

Figura 4: Organização da sala de aula para as sessões de discussão e posicionamento das câmeras para filmagem

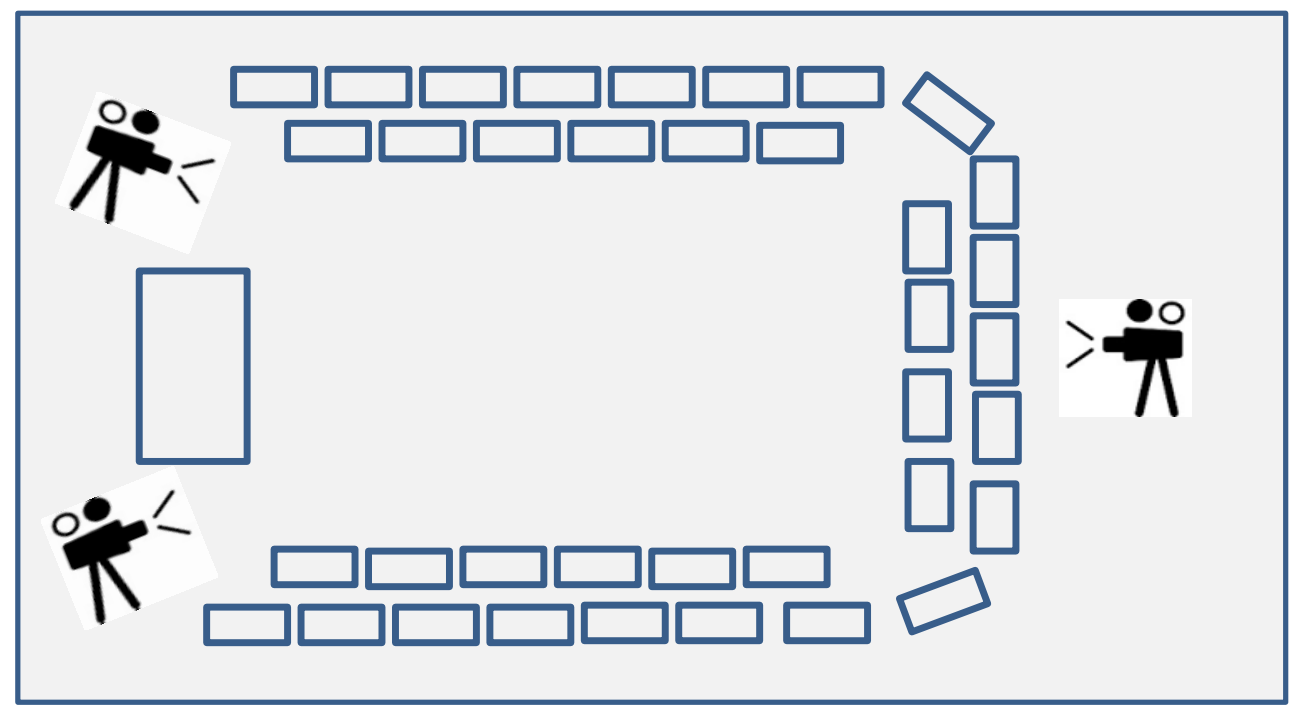

Fonte: elaboração da autora.

A realização de testes de gravação, bem como a presença de uma licencianda do curso de Química serviram para a ambientação dos estudantes com o material de filmagem. 


\subsection{Análise de dados}

Os dados da pesquisa foram extraídos de transcrições das entrevistas individuais e do questionário que foram aplicados antes da realização da oficina. Também, constituíram dados de pesquisa as transcrições das duas atividades de discussão realizadas em sala de aula e as respostas das QSC pelos estudantes.

As transcrições das discussões foram realizadas com o auxilio da ferramenta computacional $\mathrm{NVivo}^{\circledR}$ que também foi utilizada para elaboração de um mapeamento da aula que consistiu no registro dos dados temporais de fala dos estudantes e da professora pesquisadora. Essa ferramenta possibilitou a identificação de dados de frequências temporais sobre o modo de participação dos estudantes nas atividades.

O NVivo ${ }^{\circledR}$ é um programa que auxilia na organização, estruturação, busca e análise de material textual, como entrevistas, diários de campo, artigos, reportagens e atas de reuniões (TEIXEIRA; BECKER, 2001).

Nas transcrições adotamos as seguintes legendas:

TCód: estudante entrevistado, onde T representa a identificação da turma e Cód. o código atribuído a cada estudante, sem relação com o número da chamada. Ex.: A21 (turma A e 21 o código atribuído ao estudante). Essa codificação foi utilizada na entrevista, no questionário e nas respostas das QSC.

[...]: Trecho da transcrição omitido por não ser de interesse na análise.

ENT.: Entrevistador.

\subsubsection{Análise qualitativa}

As informações contidas nos questionários e nas transcrições foram processadas utilizando como referencial a Análise Textual Discursiva (MORAES; GALIAZZI, 2007). Para tanto, procedeu-se a desmontagem dos textos e a descrição da ideia principal, explícita ou implícita, de cada uma das unidades de significado, que em seguida foram agrupadas em categorias (Figura 5). 
Figura 5 - Sequência de análise textual discursiva dos discursos dos estudantes

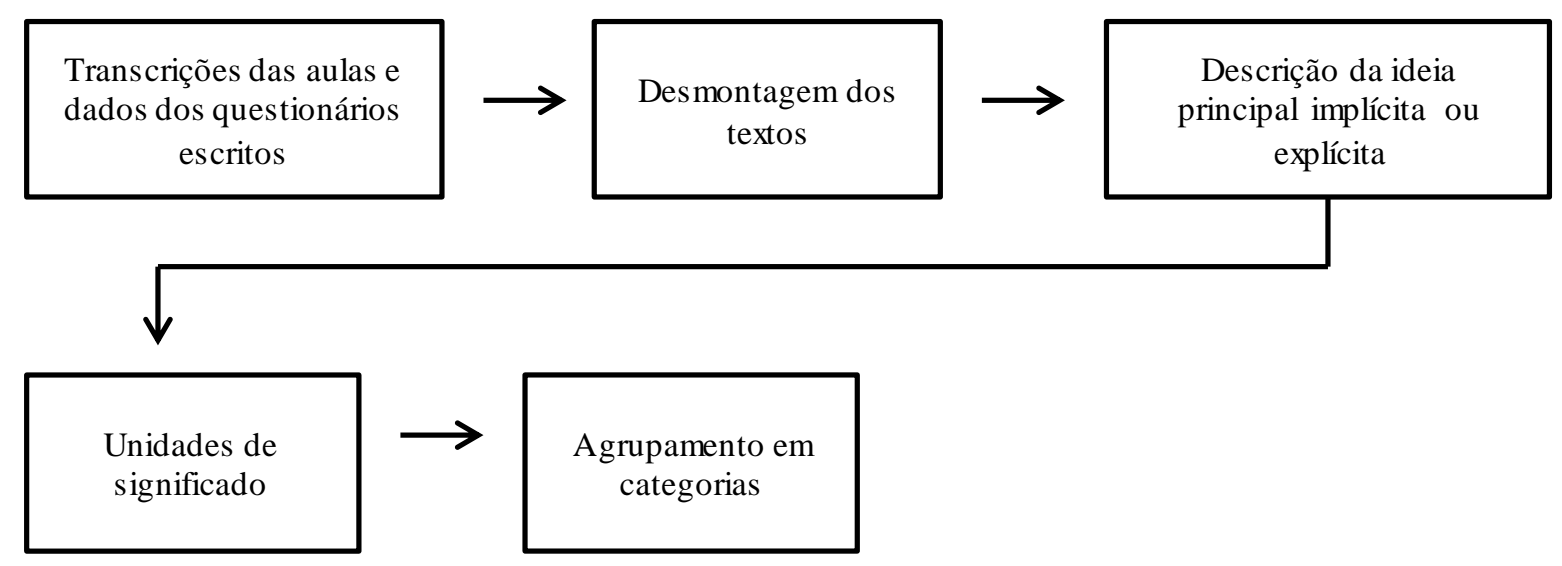

Fonte: elaboração da autora.

Assim, os discursos que apresentavam aspectos morais receberam as seguintes categorizações.

\section{1- QSC sobre transgênicos}

As categorias emergentes do discurso que foram utilizadas nas análises descritivas para os transgênicos foram: opiniões contrárias ou favoráveis à aplicação da biotecnologia; contribuição e risco; conhecimento sobre a biotecnologia; consciência ecológica; domínio moral; julgamento moral e princípio moral.

\section{A - Opiniões contrárias ou favoráveis à aplicação da biotecnologia}

Nessa categoria foram identificados discursos contrários e favoráveis aos alimentos transgênicos.

\section{B - Contribuição e risco}

Nos discursos contrários e favoráveis aos alimentos transgênicos foi possível identificar as contribuições e riscos apresentados pelos estudantes quanto a biotecnologia somente quando os estudantes consideraram apenas os benefícios, apenas os riscos ou reconheceram a existência de riscos e benefícios. Quanto aos benefícios, estes foram categorizados quanto: ao meio ambiente, a agricultura e economia, à saúde. No caso dos riscos as categorias foram: ao meio ambiente e à saúde. Quanto a dimensão temporal dos riscos se foram de curto prazo ou longo prazo. 


\section{C - Conhecimento sobre a biotecnologia}

O conhecimento científico foi uma categoria emergente nas análises dos discursos dos estudantes. Essa análise foi realizada, devido a necessidade de compreender se os estudantes incorporaram o conhecimento científico na tomada de decisão. Nos instrumentos aplicados antes da SD oportunizou-se aos estudantes demonstrar o conhecimento acerca da biotecnologia em questão, o que possibilitou a identificação do conhecimento prévio dos estudantes sobre transgênicos e o conhecimento emergente nas respostas dos mesmos nas questões apresentadas após a SD, que permitiram identificar a incorporação do conhecimento nas respostas dos estudantes.

\section{D - Consciência ecológica}

Essa categoria emergiu a partir da identificação de considerações dos estudantes sobre as seguintes categorias: somente sobre seres humanos, sobre seres sencientes ou se demonstraram preocupação com o ambiente como um todo. Essa categoria só apareceu nos discursos relacionados aos alimentos transgênicos.

\section{E - Domínio moral}

Nesse segmento os discursos dos estudantes foram categorizados em relação a considerações sobre o domínio moral ou não moral. Ressaltamos que, neste estudo, não achamos relevante identificar se os discursos do domínio não moral pertenciam aos domínios convencional ou pessoal.

\section{F - Julgamento moral}

Os discursos que apresentaram considerações do domínio moral foram categorizados de acordo com a teoria moral que aflorava dos mesmos. As teorias morais representativas dos discursos constituíram as categorias denominadas moralidade deontológica, utilitarista e ceticismo moral.

(1) Deontológica: que se refere aos direitos e deveres que temos como indivíduos com relação a outros indivíduos. É apenas a intenção de um ato que é boa, não o resultado.

(2) Utilitarista: quando uma ação é julgada como moralmente boa se consideradas as suas consequências para o bem-estar de um maior número de pessoas (utilitarismo do ato).

(3) Ceticismo moral: nome dado a um conjunto diversificado de pontos de vista que negam ou levantam dúvidas sobre vários papéis da razão na moralidade. Diferentes versões do 
ceticismo moral negam ou duvidam conhecimento moral, da crença moral, da verdade moral, de fatos ou propriedades morais e das razões para ser moral.

\section{G - Princípio moral}

Os princípios morais foram considerados por representarem os valores eleitos pelos estudantes, caracterizando assim a dimensão ético-valorativa presente nesses discursos. Para a categorização dos discursos utilizou-se alguns princípios contidos na Declaração Universal de Bioética e de Direitos Humanos (UNESCO, 2005), tais como: efeitos benéficos; efeitos nocivos; proteção do meio ambiente e da biodiversidade; proteção das gerações futuras; respeito e consideração com os animais e responsabilidade social e saúde. Outras categorias emergentes que foram elaboradas a partir dos discursos foram: autonomia da vontade (autodeterminação); conformismo moral; naturalismo conservadorista e precaução.

\section{2- QSC sobre clonagem}

$\mathrm{Na}$ QSC sobre clonagem reprodutiva as categorias emergentes do discurso foram: conhecimento sobre a biotecnologia; opiniões contrárias ou favoráveis à aplicação da biotecnologia; domínio moral; julgamento moral e princípio moral. Para a categorização dos discursos utilizou-se alguns princípios contidos na Declaração Universal de Bioética e de Direitos Humanos (UNESCO, 2005), tais como: efeitos benéficos, efeitos nocivos, autonomia e responsabilidade individual, dignidade e direitos humanos e não discriminação e não estigmatização. As outras categorias emergentes foram: individualidade genética; precaução; naturalismo conservadorista; conformismo moral; moralidade religiosa; justiça; valor da vida e não identidade

\section{3 - QSC sobre terapia gênica}

As categorias emergentes do discurso foram as mesmas da clonagem terapêutica (conhecimento sobre a biotecnologia; opiniões contrárias ou favoráveis à aplicação da biotecnologia; domínio moral; julgamento moral e princípio moral). A única diferença apresentada foi quanto à categoria princípio moral, que além de utilizar alguns princípios da Declaração Universal de Bioética e de Direitos Humanos (UNESCO, 2005), como autonomia e responsabilidade individual; efeito benéfico; proteção das gerações futuras; não discriminação e não estigmatização e efeitos nocivos, também, foram utilizados como categorias na QSC doping genético alguns princípios dos Valores do Espírito do Desporto (WADA, 2003), que 
foram: ética e honestidade; respeito pelas leis e pelas regras; dedicação e compromis so; coragem; justiça e respeito por si e pelos outros. Também emergiram nos discursos as categorias: naturalismo conservadorista; precaução e conformismo moral.

\subsubsection{Análise quantitativa}

Os resultados da análise qualitativa foram agrupados em diferentes tabelas e geraram dados quantitativos que foram utilizados na elaboração das frequências com que essas categorias emergiram. Posteriormente, esses dados serviram de base para elaboração de gráficos comparativos para análise das categorias elencadas.

Neste estudo foram realizadas análises descritivas das variáveis que se identificou no discurso dos estudantes. No caso dos transgênicos os instrumentos utilizados foram a entrevista e o questionário aplicados antes da oficina e duas QSC sobre milho e salmão transgênico.

Na clonagem terapêutica os instrumentos utilizados na análise dos dados foram a entrevista e uma QSC. No caso da clonagem o questionário inicial não contemplava nenhuma questão sobre o tema, por isso utilizou-se apenas a entrevista para constituir os dados coletados antes da oficina.

No caso da terapia gênica os instrumentos que serviram de base para a análise dos dados foram a entrevista e o questionário que constituíram os dados antes da oficina e duas QSC uma sobre albinismo contendo duas questões e outra sobre doping genético. Cabe ressaltar, que como não houve tempo para a realização do módulo sobre terapia gênica. Nesse caso, as QSC foram aplicadas em conjunto com um texto que apresentava o que era a terapia gênica e alguns aspectos relacionados a sua utilização, incluindo os riscos e benefícios dessa técnica. Além de alguns comentários sobre sua possível utilização com vistas ao melhoramento/aprimoramento de características genéticas.

Ao conjunto dos dados foram aplicados testes não paramétricos, como o teste binomial e o teste de McNemar, com o intuito de identificar se a oficina mudou a opinião dos estudantes em relação aos alimentos transgênicos, à clonagem reprodutiva e à terapia gênica nas categorias analisadas.

Ao conjunto de dados foram aplicadas análises descritivas e testes de hipóteses de variáveis qualitativas dispostas. Segundo Bussab e Morettin (2012), variáveis qualitativas apresentam resultados relativos à qualidade (ou atributo) de um indivíduo pesquisado. Os autores também explicam que uma análise descritiva é uma técnica que sumariza um conjunto de dados por meio de métodos gráficos ou tabulares. 
Abaixo segue a sistemática dos dois procedimentos, além da explicação geral sobre os principais pontos de um teste de hipótese geral.

\subsubsection{Teste de hipótese}

Teste de hipótese é uma técnica estatística em que se testa uma afirmação sobre determinada característica da população.

O teste de hipótese é composto pela hipótese nula $\left(\mathrm{H}_{0}\right)$ e hipótese alternativa $\left(\mathrm{H}_{1}\right)$. A hipótese nula é formulada a partir do conhecimento prévio que se tem sobre a população estudada, ou seja, sobre a distribuição de probabilidade do parâmetro, já a hipótese alternativa é aquela que se pretende testar. A rejeição ou não da hipótese nula é baseada em uma estatística obtida a partir da amostra. Em um nível mais geral:

$$
\begin{aligned}
& \mathrm{H}_{0}: \theta=\theta_{0}(1) \\
& \mathrm{H}_{1}: \theta \neq \theta_{0}(2)
\end{aligned}
$$

Poderíamos, ainda, ter alternativas da forma dependendo do que é desejado

$$
\mathrm{H}_{1}: \theta<\theta_{0} \text { ou } \mathrm{H}_{1}: \theta>\theta_{0},
$$

Para que a decisão seja tomada, necessita-se de uma estatística teste (função relacionada ao que se deseja testar baseada nos valores amostrais) e da construção da região crítica. A região crítica é composta pelos valores para os quais a hipótese nula é rejeitada, ou seja, caso a estatística teste retorne um valor que está dentro da região crítica, rejeita-se a hipótese nula.

Outra forma para a tomada de decisão é o chamado p-valor, que é a probabilidade de se observar valor igual ou mais extremo que o observado na amostra. Se o p-valor for menor que o nível de significância a hipótese nula é rejeitada.

$\mathrm{O}$ valor $\alpha$ recebe o nome de nível de significância. Esse valor é a probabilidade de se rejeitar a hipótese $\mathrm{H}_{0}$ dado que ela é verdadeira.

a) Teste binomial

Teste utilizado para comparação entre duas proporções. Para seu uso, as observações da amostra devem consistir em $n$ ensaios independentes de Bernoulli (isto é, admite apenas dois resultados: sucesso ou fracasso) e pressupõe-se que os mesmos são independentes e têm a mesma probabilidade, $\mathrm{p}$, de ocorrer.

Sendo X o número de sucessos observados, tem-se que $\mathrm{X}$ segue uma distribuição binomial com parâmetros $\mathrm{n}$ e p. 
No caso de um teste binomial, as hipóteses são:

$$
\begin{aligned}
& H_{o}: p=p_{0}(1) \\
& H_{1}: p \neq p_{0}(2)
\end{aligned}
$$

onde:

p: proporção de sucessos observada na amostra;

$\mathrm{p}_{0}$ : proporção de sucessos que se deseja testar.

A estatística do teste é o número observado de sucessos na amostra, ou seja, X.

A hipótese de igualdade entre as proporções é rejeitada se

$$
X>t_{2} \text { ou } X<t_{1}
$$

Sendo, $\mathrm{t}_{1}$ e $\mathrm{t}_{2}$ valores tais que $P\left(X<t_{1}\right)=P\left(X>t_{2}\right) \approx \frac{\alpha}{2}$.

Em caso de grandes amostras, a distribuição $X$ se aproxima de uma normal e a estatística de teste passa a ser:

$$
z=\frac{x-n p_{0}}{\sqrt{n p_{0}\left(1-p_{0}\right)}}
$$

E rejeita-se $H_{0}$ se $z>z_{1-\alpha / 2}$, sendo $z_{1-\alpha / 2}$ o quantil $1-\alpha / 2$ de uma distribuição normal padrão, ou se o p-valor observado for menor do que o nível de significância do teste.

b) Teste de McNemar

O Teste de McNemar tem como objetivo detectar mudanças em planejamentos do tipo "antes e depois", em que cada unidade amostral é seu próprio controle. Por exemplo: analisar se um evento $\mathrm{X}$ altera a opinião ou a conduta de um evento $\mathrm{Z}$. Para que isso ocorra as mensurações podem ser feitas na escala ordinal ou nominal. Há interesse em verificar as seguintes hipóteses estatísticas:

$\mathrm{H}_{0}: \mathrm{O}$ evento $\mathrm{X}$ não alterou a ocorrência de $\mathrm{Z}$.

$\mathrm{H}_{1}$ : O evento $\mathrm{X}$ alterou a ocorrência de $\mathrm{Z}$.

Para a formulação da estatística do teste é construída uma tabela de contingência $2 \times 2$ representando o "sucesso" e "insucesso" de cada evento "antes" e "depois".

Tabela exemplo do teste McNemar.

Depois

\begin{tabular}{cc|cc}
\cline { 2 - 4 } & & Sucesso & Insucesso \\
\cline { 2 - 4 } Antes & Sucesso & $\mathrm{A}$ & $\mathrm{B}$ \\
& Insucesso & $\mathrm{C}$ & $\mathrm{D}$ \\
\hline
\end{tabular}


Logo, a estatística do teste é dada por:

$$
Q_{M c N e m a r}^{2}=\frac{(B-C)^{2}}{B+C} \approx X_{(1)}^{2}
$$

A hipótese nula é rejeitada caso o p-valor seja menor que o nível de significância previamente especificado.

Em seguida, serão apresentados resultados obtidos da análise sobre o tema transgênicos, a partir da análise descritiva e dos testes não-paramétricos, tais como o teste binomial e o teste de McNemar. 



\section{RESULTADOS E DISCUSSÃO}

O presente capítulo foi estruturado de modo a apresentar respostas as questões de pesquisa. Para tanto, serão apresentados os resultados das análises referentes às categorias emergentes nos discursos dos estudantes que foram elencadas após a realização da análise textual discursiva.

\subsection{Análise de aspectos morais dos estudantes no estudo das QSC}

Os aspectos morais constituíram categorias de análise que foram apresentadas no cap. 2, que se referem ao domínio moral, ao raciocínio moral deontológico, utilitarista e ceticismo moral e aos princípios morais adotados pelos estudantes, conforme os tópicos abaixo.

\subsubsection{QSC sobre transgênico}

A análise descritiva dos dados iniciou-se pela categoria tomada de decisão, onde foram considerados se os estudantes decidiram ou não em relação ao uso/consumo de alimentos transgênicos.

\section{A - Opiniões contrárias ou favoráveis à aplicação da biotecnologia}

No gráfico 1 estão apresentados os dados da análise referente à opinião dos estudantes quanto a serem contrários, favoráveis, respostas em branco ou sem opinião e argumentos insuficientes para categorizar. 
Gráfico 1 - Distribuição da frequência de estudantes em relação ao uso de alimentos transgênicos

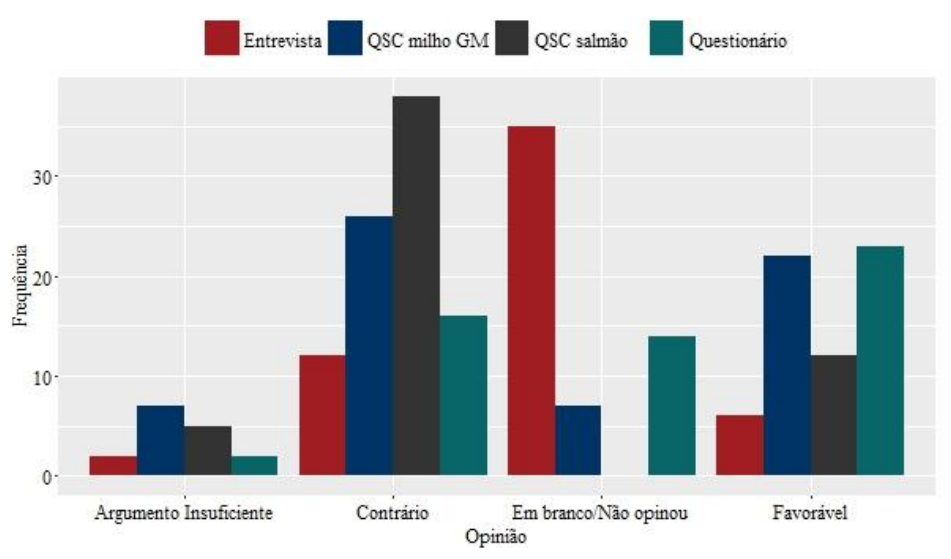

Fonte: elaboração da autora.

Na entrevista observou-se que dos 12 de 55 (21,82\%) estudantes foram contrários ao uso de alimentos transgênicos e seis de 55 (10,90\%) foram favoráveis ao uso dos alimentos transgênicos, 35 de $55(63,64 \%)$ não opinaram e dois de $55(3,64 \%)$ apresentaram argumentos insuficientes para categorizar.

Quando foi perguntado por meio de questionário se eles utilizariam alimentos transgênicos na alimentação, 16 de $55(29,09 \%)$ disseram que não utilizariam alimentos transgênicos, enquanto 23 de $55(41,82 \%)$ disseram que utilizariam. Sendo que 14 de 55 $(25,45 \%)$ estudantes não opinaram e dois de 55 (3,64\%) apresentaram argumentos insuficientes.

Após a realização da oficina, quando foi perguntado se o milho transgênico trazia risco ou contribuição à saúde das pessoas, 26 de 62 (41,93\%) afirmaram ser contrários, 22 de 62 $(35,48 \%)$ disseram ser favoráveis, sete de $62(11,29 \%)$ não opinaram e sete de $62(11,29 \%)$ não apresentaram argumentos suficientes para categorizar. Ressaltamos que o total de argumentos (62) aumentou em relação ao número de participantes (55), pois sete estudantes disseram que o milho transgênico trazia riscos e contribuições.

Quando os estudantes foram questionados sobre o salmão transgênico, 38 de 55 $(69,09 \%)$ foram contrários ao uso, 12 de $55(21,81 \%)$ foram favoráveis e cinco de $55(3,1 \%)$ não apresentaram argumentos suficientes para a categorização.

Observou-se que, tanto na entrevista quanto no questionário os estudantes foram contrários a utilização dos transgênicos. Após a discussão de QSC, notou-se que a maioria continuou sendo contrária ao uso de alimentos transgênicos. Sendo que a frequência de estudantes contrários aumentou em relação ao salmão transgênico. 
Um número elevado de estudantes que deixaram em branco ou não opinaram ficou evidente no momento da entrevista e do questionário realizados antes da SD. Nesse momento, observou-se que os estudantes tiveram dificuldade de justificar suas respostas e apresentaram erros conceituais, muito provavelmente pelo desconhecimento do que são transgênicos, conforme o exemplo a seguir em que o estudante relaciona os transgênicos ao uso de agrotóxicos.

ENT.: Você já ouviu falar de alimentos transgênicos? Algo do tipo assim. B17: Já... ENT.: Você sabe o que é um transgênico? É um alimento que meio que sofre uma transformação. ENT.: Isso. É geneticamente modificado. E você já tem uma opinião sobre isso? Você acha que é bom, é ruim? B17: Ele até poderia ajudar em algumas certas coisas na nossa saúde, mas meu pensamento é meio que como ele sofre transformações acho que química eu acredito que os alimentos que já vem naturalmente ajuda mais a gente que os alimentos transgênicos. Então você seria meio que contra? É. (B17)

Não, pois poderá conter muita química. (B17)

No Brasil, poucas são as pesquisas realizadas sobre a temática das atitudes das pessoas em relação a genética e biotecnologia, entretanto algumas pesquisas realizadas corroboram com os dados encontrados no neste estudo. Podemos citar pesquisas realizadas pelo Instituto Brasileiro de Opinião Pública e Estatística (IBOPE), em 2001, 2002 e 2003 que explorava m a opinião pública sobre os alimentos geneticamente modificados.

A pesquisa realizada pelo IBOPE (2001) sobre as culturas transgênicas mostrou que $74 \%$ dos brasileiros preferiam alimentos não modificados geneticamente, enquanto $14 \%$ apoiavam o uso de alimentos geneticamente modificados. Nessa pesquisa foi observado que quanto maior o nível de escolaridade, maior o percentual de pessoas que preferiam alimentos não modificados geneticamente, por exemplo: $85 \%$ dos entrevistados com nível universitário apresentavam oposição aos alimentos modificados geneticamente.

No inquérito realizado pelo IBOPE (2002) os resultados foram semelhantes. Em 2003, o IBOPE publicou resultados de outra pesquisa sobre o assunto, mostrando que, dos dois mil brasileiros entrevistados, apenas $37 \%$ já tinham ouvido falar dos transgênicos e $71 \%$ disseram que, se pudessem escolher, prefeririam consumir alimentos não manipulados geneticamente.

Outra perspectiva que, à priori, poderia se estabelecer é a polarização dos discursos pró e contra a utilização de alimentos transgênicos. Veja essa polarização nos discursos que se seguem: 
$\underline{\text { Favorável }}$

ENT.: Tudo bem. E transgênicos? E10: Que é modificação né? Que geralmente a pessoa usa em alimentos. ENT.: Você já ouviu falar? E10: Já, de modificar alimentos e melhorar alguma coisa. ENT.: Mas você é contra ou a favor aos transgênicos? E10: Eu sou a favor. ENT.: Por que você é a favor? Porque é um jeito de criar novas coisas com a mesma função ou tipo assim se ocorrer uma falta de alguma coisa pode substituir. E10: Você me entendeu, né. (E10)

Sim, pois estudos comprovado que eles estão ligados a uma saúde melhor. (A16)

Sim, pois acaba com os danos causados por insetos-praga. (A10)

Sim, apesar de beneficiar mais o comércio pelo crescimento acelerado o preço aumenta, não sei se influencia na questão da qualidade do produto, mas consumiria da mesma forma. (B17)

\section{Contrário}

ENT.: Transgênicos? B14: Transgênicos, ah, dos alimentos né? ENT.: Isso. B14: Que são geneticamente modificados. ENT.: Isso, são modificados geneticame nte. Você é a favor ou contra? B14: Contra. ENT.: Por quê? B14: Ah, como eu já tinha falado, é que muitas vezes a galera não sabe como, o que pode acontecer futuro com a gente. Então pode trazer um câncer esses alimentos, então não. (B14)

Não. Por que não sei se isso iria me fazer bem ou me causar uma doença no futuro. (A25)

Eu discordo, pois, o milho Bt apresenta vantagens no aumento da produção, financeiramente, no impacto ambiental. Porém o número de pragas irá aumentar e o mais importante os riscos à saúde, os estudos não são conclusivos sobre a saúde, mais provavelmente deve ter. E o mais importante para mim, primeiro é a saúde apesar de uma economia também é importante. (B7)

Não, eu creio que a natureza tenha sua estabilidade. Não há necessidade da intervenção do homem. Além de causar desequilíbrio na cadeia alimentar. (C26)

Duas preocupações principais foram apresentadas discursos polarizados: a) as contribuições que os transgênicos podem trazer, ou seja, o estabelecimento de um conhecimento biotecnocientífic o como meio para se ter melhor qualidade de vida; e b) os riscos que representam uma reação negativa diante dos alimentos transgênicos que podem estar relacionados à saúde, aos ambientes naturais e sociais.

A partir desses dois polos identificados nos discursos realizou-se a análise das categorias evidenciadas (contribuição e risco). 


\section{B - Contribuição e risco}

No gráfico 2 são apresentados os dados referentes a distribuição das frequências de estudantes quanto a contribuição e risco.

Gráfico 2 - Distribuição da frequência de estudantes quanto às percepções de contribuição e risco por instrumento

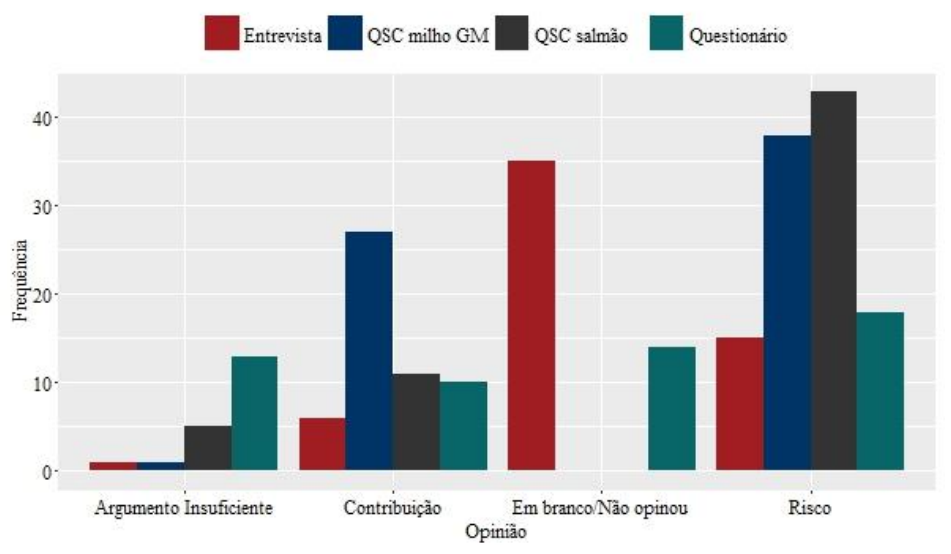

Fonte: elaboração da autora.

Observou-se que dos 57 estudantes entrevistados apenas seis (10,53\%) responderam que os alimentos transgênicos trazem alguma contribuição, 15 de 57 (26,32\%) apontaram a existência de riscos quanto ao uso/consumo de alimentos transgênicos, 35 de 57 (61,40\%) dos estudantes não opinaram e um de $57(1,75 \%)$ apresentou argumento insuficiente para a categorização. No questionário 10 de $55(18,20 \%)$ disseram que os alimentos transgênicos trazem alguma contribuição, 18 de $55(32,72 \%)$ apontaram a existência de riscos, 14 de 55 $(25,45 \%)$ deixaram a questão em branco ou não opinaram e 13 de $55(23,63 \%)$ apresentaram argumentos insuficientes para a categorização.

$\mathrm{Na}$ QSC sobre o milho transgênico observou-se 27 ocorrências (40,91\%) de argumentos relacionados a contribuição, 38 (57,58\%) que se referiram ao risco e apenas um $(1,51 \%)$ argumento insuficiente para categorizar. Na QSC salmão transgênico observou-se 11 ocorrências $(18,64 \%)$ que apontavam contribuição, 43 (72,88\%) para risco e cinco $(8,48 \%)$ de argumentos insuficientes para categorização.

A partir da análise dos dados (Gráfico 2) observou-se que um número significativo dos estudantes não soube responder à questão nos instrumentos aplicados antes da realização da SD sobre transgênicos, na entrevista $61,40 \%$ e no questionário $25,45 \%$. Após a realização da SD sobre transgênicos, todos os estudantes responderam as QSC sobre o milho e o salmão transgênicos o que demonstra que houve uma redução significativa da frequência de não 
respondentes, após o desenvolvimento da SD. Esse fato, sugere que inicialmente muitos estudantes não tinham conhecimento sobre o assunto e em decorrência disso não conseguiam expor suas opiniões. Esse resultado evidencia a importância do conhecimento científico para a tomada de decisão.

É importante notar que houve um aumento na consideração de risco após a realização da SD, sugerindo que a incorporação do conhecimento científico propiciou um aumento da percepção de risco sobre os alimentos transgênicos.

Quanto a contribuição e risco dos alimentos transgênicos os discursos dos estudantes houve polarização com a ocorrência de discursos biotecnofílicos que apontaram contribuição e biotecnofóbicos que se apoiaram nos riscos. Os trechos de discursos abaixo, ilustram a biotecnofília para os quais qualquer nova tecnologia é, em princípio, bem-vinda, sem se preocupar com seus eventuais efeitos negativos presentes ou futuros.

Em alguns discursos percebeu-se a ideia que os transgênicos para consumo humano possuem uma qualidade nutricional superior a dos alimentos convencionais e que esses podem contribuir para uma melhor nutrição e saúde.

[...] ENT.: Você concorda, é contra? E1: Concordo, justamente pelo fato se ele foi modificado foi para melhorar porque ninguém pega um alimento e modifica ele para ele ficar sem a vitamina, a não ser que ele tenha sido modificado para ficar sem essa vitamina porque haja pessoas que tenham alergia a essa vitamina ou que essa vitamina não esteja sendo bem utilizada pelo nosso organismo. (E1) Sim, eles são modificados com intenção de uma melhoria na nossa nutrição. (E2) Sim, por que ele é utilizado para fornecer nossa saúde. (D1)

Alguns discursos demonstraram a crença de que a biotecnociência represente uma solução para os maiores problemas mundiais como a fome e a desnutrição, conforme exemplo a seguir:

com o crescimento populacional cada vez mais os alimentos transgênicos são utilizados por conta da grande demanda. O milho Bt que foi introduzido no Brasil foi estudado e não foi comprovado outros malefícios aos humanos além de uma pequena indigestão depois de uma grande quantidade. (E2)

Também, encontrou-se discursos opostos que expressaram a ideia de que os alimentos transgênicos são produtos artificiais, por isso a rejeição em consumi-los. 
Não concordo! Particularmente acredito que isso não seja saudável para nossa saúde. Acho que tem que ser algo mais natural, saudável... Nossa saúde é mais importante. Acho que poderia ter outro meio mais natural. (D12)

Discordo em parte, pois até o momento, estudos não apontam riscos para a saúde, porém por ser um alimento geneticamente modificado, ele acaba perdendo as suas características originais de sabor e sua naturalidade, então, pode ser que faça falta de alguma forma no nosso organismo. (B3)

Ainda, em relação aos discursos opostos ao consumo de alimentos transgênicos identificou-se os que se opõem por acreditarem que esses alimentos possam trazer riscos. Esses discursos revelaram a biotecnofobia entre alguns estudantes que apresentaram uma reação negativa diante das aplicações da biotecnociência.

Não, por que não é saudável. (B26)

Discordo. O milho $\mathrm{Bt}$ traz muita riqueza para os agricultores, mas para nós seres humanos não, ele traz muitos malefícios a saúde. Então eu discordo o uso do milho Bt para consumo humano. (B13)

Não, pois estudos dizem que a alta quantidade de hormônios encontrado no salmão é prejudicial à saúde. E o que está relacionado a riscos à saúde não me interessa. (B7)

Também, houve um discurso que revelou uma preocupação com o consumo do milho, devido a existência do gene responsável pela produção de uma toxina com ação insetic ida, considerando que essa poderia ser tóxica, também, para os seres humanos.

Não, sou contra o consumo de transgênicos, apesar de que em nossa sociedade tudo o que compramos é transgênico. Se pararmos para pensar estamos consumindo, de certa forma, milho com inseticida, isso tem um efeito sobre nosso corpo, mesmo que tardio. Alimentos transgênicos são um golpe capitalista, mais produção representa mais dinheiro, e os transgênicos são mais dinheiro. (B14)

Alguns estudantes se referiram a acumulação de agrotóxicos como algo prejudicial que está relacionado aos alimentos transgênicos, porém nesses discursos percebeu-se a existência de uma dificuldade conceitual, pois os estudantes se referiram "a química dos transgênicos" não deixando claro se está relacionada ao produto do gene inserido ou ao uso indiscriminado de agrotóxicos e herbicidas nas plantações.

Entendo que o milho para consumo, ideal seria vir sem qualquer tipo de remédio, veneno ou qualquer outra substância não natural. Neste caso, pode até surgir algum problema ainda não detectado hoje como forma de alimento, não concordo em utilizar o milho. (C4) 
Eu discordo, mas querendo ou não sempre vamos acabar consumindo transgênico, pois está por toda parte, além de que é muito dificil achar alimentos "puros" que não contém a química dos transgênicos. (A15)

Massarani e Moreira (2005) em um estudo com 610 estudantes do $2^{\circ}$ ano do EM de escolas públicas e particulares no Brasil, sobre as atitudes dos jovens diante das tecnologias da genética, incluindo a transgenia de alimentos e plantações, observaram que uma parte significativa $(65,5 \%)$ dos estudantes analisados concordou que é útil para a sociedade usar a biotecnologia moderna na produção de alimentos, por exemplo: aumentando seu teor de proteínas, tornando-os maiores ou mudando o gosto. Entretanto, o percentual de estudantes que apontaram a existência de riscos foi maior $(77,6 \%)$.

Para a formação de atitudes em relação as tecnologias emergentes, a percepção de risco é considerada importante (SJÖBERG, 2002, p. 380), pois a aceitação ou resistência a novas tecnologias são influenciadas pela percepção dos riscos ou benefícios que essas tecnologias trazem (MOON; BALASUBRAMANIAN, 2004; SJÖBERG, 1999).

As avaliações de risco podem ser influenciadas por componentes afetivos e cognitivos. Os componentes afetivos deflagram reações intuitivas ao perigo e os componentes cognitivos permitem uma avaliação lógica com deliberação científica para apoiar a avaliação de risco e a tomada de decisão (SLOVIC; PETERS, 2006). Componentes afetivos, como o medo de um perigo podem ser igualmente importantes na definição do que é considerado arriscado (FINUCANE et al., 2000; SLOVIC; PETERS, 2006). A integração de componentes cognitivos e afetivos, além das experiências de um indivíduo, contribuem para os limites de sua percepção que podem gerar respostas comportamentais, tais como a participação no ativismo a favor ou contra o desenvolvimento de novas tecnologias (GARDNER, 2009).

A partir da análise da categoria "contribuição e risco" foi possível identificar se os estudantes reconheciam somente benefícios ou somente os riscos, se reconheciam benefícios e riscos, se admitiam os riscos e se conformavam ou se não se consideravam suficientemente informados, conforme gráfico 3 . 
Gráfico 3 - Distribuição da frequência de estudantes em relação a percepção de riscos e benefícios dos alimentos transgênicos
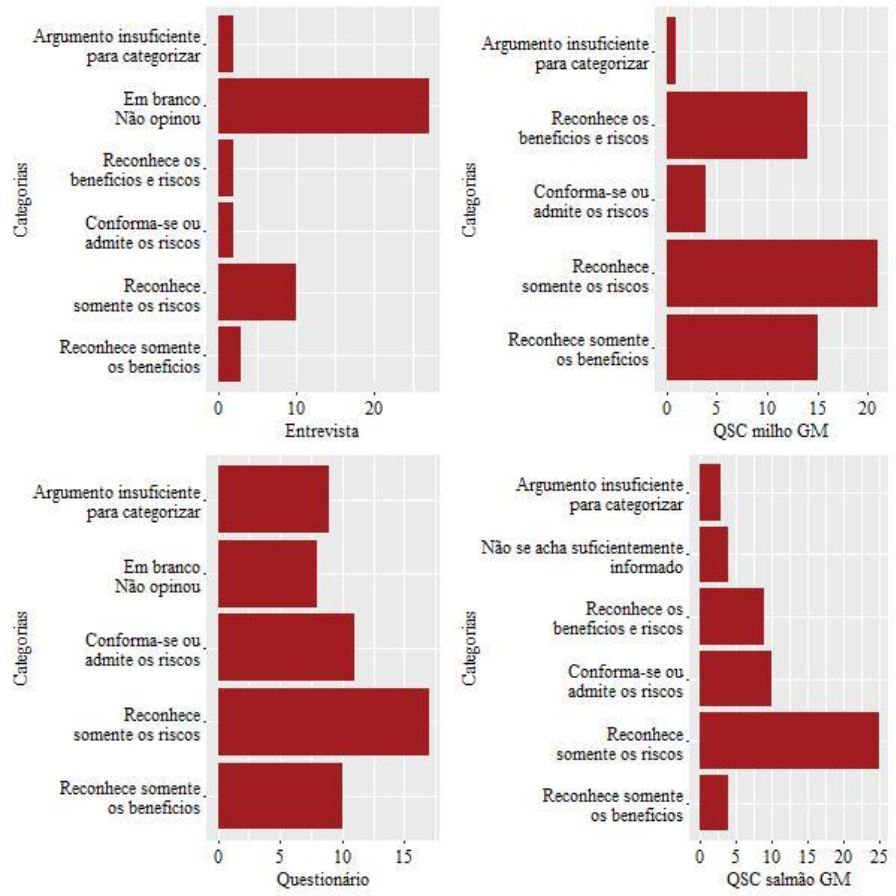

Fonte: elaboração da autora.

$\mathrm{Na}$ entrevista três (6,52\%) reconheceram apenas benefícios, $10 \quad(21,74 \%)$ reconheceram somente riscos dois (4,35\%) conformaram-se ou admitiram os riscos, dois $(4,35 \%)$ reconheceram riscos e benefícios, 27 (58,70\%) não opinaram e dois $(4,35 \%)$ apresentaram argumentos insuficientes para categorizar. No questionário $10 \quad(18,18 \%)$ reconheceram somente benefícios, $17(30,91 \%)$ reconheceram somente os riscos, $11(20 \%)$ conformaram-se ou admitiram os riscos, oito $(14,55 \%)$ deixaram em branco ou não opinaram e nove $(16,36 \%)$ estudantes apresentaram argumentos insuficientes para categorizar.

Na QSC milho $15(27,27 \%)$ dos estudantes reconheceram somente os benefícios, 21 $(38,18 \%)$ reconheceram somente riscos, $14(25,45 \%)$ reconheceram riscos e benefícios e apenas um $(1,82 \%)$ estudante apresentou argumento insuficiente para categorizar. Na QSC salmão quatro $(7,27 \%)$ reconheceram apenas benefícios, $25(45,45 \%)$ reconheceram apenas os riscos, $10(18,18 \%)$ reconheceram riscos e benefícios, quatro $(7,27 \%)$ não se acharam suficientemente informados para opinar e três $(5,45 \%)$ apresentaram argumentos insuficientes para categorizar.

A categoria reconhece somente os riscos, foi a mais evidente no questionário, na QSC milho e na QSC salmão. A seguir são apresentados discursos de estudantes que reconheceram apenas os riscos associados aos alimentos transgênicos. 
ENT.: Não. Transgênicos? Alimentos transgênicos? B2: Já, já ouvi falar. ENT.: O que você sabe? B2: Eu acho que são os alimentos que fazem, acabam fazendo mal se você, se você ingerir eles por muito tempo. Acho que é alguma coisa assim. ENT.: Você seria contra ou a favor? B2: Eu seria contra alguns alimentos. ENT.: Transgênicos? B2: Uhum. ENT.: Por quê? B2: Pelo fato de eles fazerem, pelo que eu sei né, fazer mal pra gente. (B2)

Alimentos transgênicos já fazem parte da nossa alimentação, mas é algo do qual eu não concordo, pois podem fazer mal a nossa saúde. Porém é bem difícil controlar a utilização desses alimentos. (B3)

Discordo, pois o consumo desse alimento pode vir causar doenças e outro problema no organismo. (B22)

Não por que o salmão contém $40 \%$ de hormônios a mais do que a espécie comum gerando doenças e não temos conhecimento de que essa espécie nova pode causar doenças desconhecidas e também afetaria sua espécie de origem levando-a a extinção. (D15)

Identificou-se discursos que se referiram apenas aos benefícios, apresentando a ideia de melhoria, ou seja, que a modificação genética é realizada para melhorar o alimento.

D13. Uhumm, tá. Transgênicos? ENT.: Você já ouviu falar? E1: Já. São os alimentos modificados, né? ENT.: Sim, o que você acha sobre isso? Você concorda, é contra? E1: Concordo, justamente pelo fato se ele foi modificado foi para melhorar porque ninguém pega um alimento e modifica ele para ele ficar sem a vitamina, a não ser que ele tenha sido modificado para ficar sem essa vitamina porque haja pessoas que tenham alergia a essa vitamina ou que essa vitamina não esteja sendo bem utilizada pelo nosso organismo. (E1)

Nos discursos identificou-se equívocos como a ideia de que os alimentos transgênicos têm mais nutrientes que os alimentos não transgênicos (convencionais) e que essa riqueza nutricional pode proporcionar a esse organismo mais saúde, conforme o exemplo abaixo:

os alimentos transgênicos são maiores, coloridos e cheios de proteínas e vitaminas que fazem bem para saúde. (D5)

Também, emergiram discursos que apontavam benefícios para a agricultura e para o atendimento da população com maior eficiência.

Concordo ele pode se tornar um grande aliado no futuro para a agricultura e para uma melhor produção desse milho, os alimentos transgênicos vieram para o benefício da população. (C11)

Com certeza, pois não apresenta danos à saúde, sem falar que ele atende ao consumidor com mais eficiência. (D13) 
Observou-se discursos que apontaram a existência de riscos, mas conformaram-se com eles, achando que não há possibilidade de mudança, de retirada dos alimentos transgênicos do mercado. Em alguns casos os estudantes demonstram que a decisão de consumir ou não os produtos transgênicos não seria deles.

Não, mas como muitos dos alimentos que comemos, atualmente, já vem modificados, então sim. (B14)

Com o crescimento populacional cada vez mais os alimentos transgênicos são utilizados por conta da grande demanda. $\mathrm{O}$ milho Bt que foi introduzido no Brasil foi estudado e não foi comprovado outros malefícios aos humanos além de uma pequena indigestão depois de uma grande quantidade. (E2)

Alguns estudantes ponderaram sobre a existência de riscos e benefícios.

A produção desses peixes para a pesca se torna mais rápido e fácil, visando no aumento do lucro. Pode ser citado como um pró. Em compensação esse excesso de hormônios pode acarretar em males a saúde dos consumidores. (E15)

Minha opinião está entre os dois termos, o uso do milho Bt pode ser benéfico e ao mesmo tempo trazer riscos. Os riscos à saúde ainda não são conclusivos, o que preocupa a sociedade. (B26)

Por outro lado, alguns estudantes mesmo após a SD não se acharam suficientemente informados para a tomada de decisão em relação aos alimentos transgênicos. Como vemos nos discursos baixo os estudantes ainda demonstram incerteza quanto aos riscos à saúde.

Compraria, desde que não afete minha saúde. (C16)

Eu compraria se tivesse certeza de que o salmão não traria risco à minha saúde. (C22)

Em relação a categoria contribuição identificou-se discursos que especificavam o tipo de benefício relacionado aos alimentos transgênicos, como: benefício à saúde, à agricultura e economia, ao meio ambiente, se não apresentou argumentos quanto a quaisquer benefícios, em branco/não opinou e argumentos insuficientes para categorizar.

O gráfico 4 apresenta os dados relacionados a distribuição da frequência de estudantes com sua respectiva categorização quanto ao tipo de benefício. 
Gráfico 4 - Distribuição da frequência de estudantes em relação aos benefícios dos alimentos transgênicos
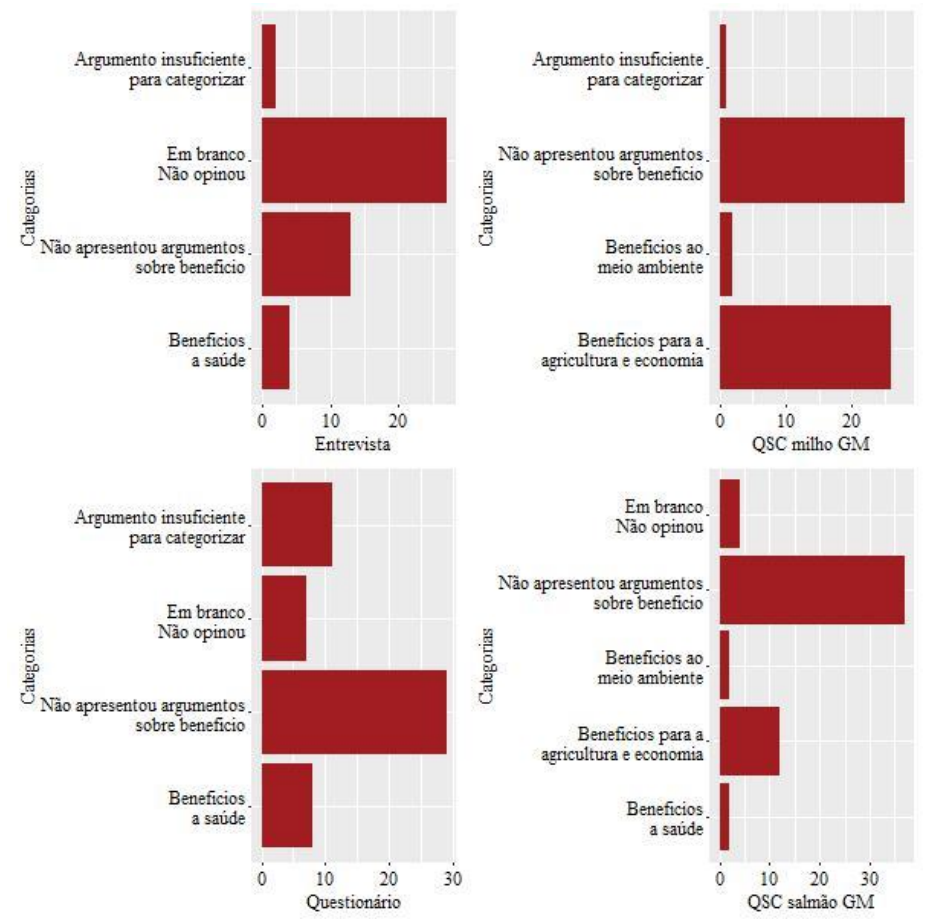

Fonte: elaboração da autora.

O total de algumas observações apresenta variações, pois as categorias não são auto excludentes. $\mathrm{Na}$ entrevista quatro $(8,70 \%)$ estudantes relataram benefício para a saúde, 13 $(28,26 \%)$ não apresentaram argumentos sobre benefícios, $27(58,70 \%)$ não opinaram e dois $(4,35 \%)$ apresentaram argumentos insuficientes para categorizar. No questionário oito (14,55\%) estudantes relataram benefício a saúde, 29 (52,73\%) não apresentaram argumentos sobre benefício, sete $(12,73 \%)$ não responderam e $11(20 \%)$ apresentaram argumentos insuficientes para categorizar.

Na QSC milho transgênico $26(45,61 \%)$ dos estudantes relataram benefício para a agricultura e economia, dois $(3,51 \%)$ benefícios ao meio ambiente, 28 (49,12\%) não apresentaram argumento sobre benefício e um (1,75\%) apresentou argumento insuficiente para categorizar. Na QSC salmão transgênico dois $(3,51 \%)$ apresentaram benefício a saúde, 12 $(21,05 \%)$ apresentaram benefício para a economia, dois $(3,51 \%)$ benefícios ao meio ambiente, $37(64,91 \%)$ não apresentaram argumentos sobre benefícios e quatro $(7,02 \%)$ deixaram em branco ou não opinaram.

Nos discursos apresentados pelos estudantes identificou-se a presença de benefícios a saúde. 
Sim, por que ele é utilizado para fornecer nossa saúde. (D1)

Sim, pois o salmão terá maior quantidade de proteína. (A16)

Outros estudantes fizeram referência aos benefícios para a agricultura e economia.

Concordo, pois se o milho transgênico diminui os danos causados por insetos praga isso vai melhorar os alimentos que possui a larva de alguns insetos. (E25)

Concordo, pois ele aparentemente apresenta ter muito mais benefícios como uma melhor colheita, um tamanho maior, mas sem mudar seu valor nutricional. A única coisa que ainda me faz ter dúvidas é o fato de poder prejudicar a saúde a longo prazo. (B19)

Nos discursos dos estudantes, também revelaram benefícios ao meio ambiente.

Sim, pois com a ação do Bt, pois a própria ação anti-inseticida faz com que o produtor use menos química nas plantações. (D13)

$\mathrm{Sim}$, pois eles crescem mais rápido podem diminuir a pesca do peixe e serem criados em cativeiro e se não tem nenhum fator que altere a carne ou que atrapalhe o meio tampouco a digestão eu acredito que deve ser aceito. (E1)

Nesse contexto, percebeu-se que os discursos individuais revelaram a ideia de benefício associada aos transgênicos como melhoria na qualidade nutricional, por serem mais resistentes contra pragas ou crescerem mais rápido e por reduzirem o impacto ambiental, devido à redução do uso de agrotóxicos, entretanto cada transgênico tem uma construção genética diferente, por isso a característica desejada vai depender do gene inserido e de suas interações com os outros genes. Esse fato, leva a necessidade de uma avaliação individual de cada transgênico e de suas interações com o organismo e com o meio ambiente.

Cabe esclarecer o fato que cada transgênico estudado na SD foi tratado a nível do gene inserido e, portanto, das especificidades de cada um em relação aos efeitos no organismo e meio ambiente.

Os discursos relacionados aos tipos de benefícios apresentados pelos estudantes refletiram os valores que integram as concepções do desenvolvimento econômico da sociedade atual, por exemplo: produtividade, lucro, eficiência econômica, revelando o controle do homem sobre a natureza e seus processos.

Para Lacey (2002) esses valores demonstram uma ruptura ecológica e social causada por muitas inovações tecnocientíficas, e são simplesmente interpretados como o preço do progresso. Eles envolvem a compreensão de que o controle é uma característica humana e que 
com a expansão de tecnologias avançadas mais problemas serão resolvidos, inclusive os resultantes das próprias inovações tecnológicas. Esses discursos que se relacionam ao controle nas práticas agrícolas revelam uma distância em relação a valores como sustentabilidade ambiental, preservação da biodiversidade e do crescimento da comunidade e da emancipação social.

A partir dos discursos dos estudantes, também emergiram considerações sobre o tipo de risco, se esse está relacionado a saúde ou ao meio ambiente.

O gráfico 5 apresenta a distribuição da frequência das categorias relacionadas ao tipo de risco relacionados aos alimentos transgênicos antes e depois da SD sobre transgênicos.

Gráfico 5 - Distribuição da frequência de categorias relacionadas a percepção dos estudantes em relação aos riscos dos alimentos transgênicos
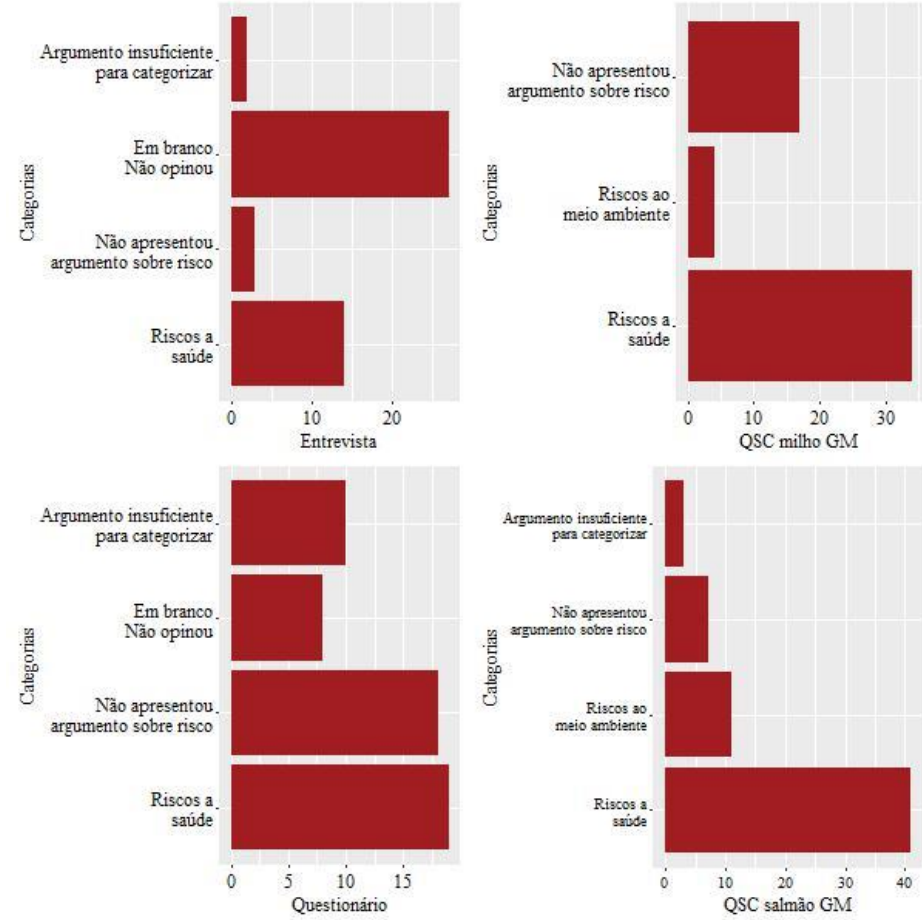

Fonte: elaboração da autora.

Quanto ao tipo de risco na entrevista $14(30,43 \%)$ dos estudantes relatam riscos à saúde, três $(6,52 \%)$ não apresentaram argumentos sobre risco, $27(58,70 \%)$ não opinaram e dois $(4,35 \%)$ apresentaram argumentos insuficientes para categorização. No questionário, 19 $(34,55 \%)$ relataram riscos à saúde, 18 (32,73\%) não apresentaram argumentos sobre risco, oito $(14,55 \%)$ deixaram em branco ou não opinaram e $10(18,18 \%)$ apresentaram argumento insuficiente para categorização. 
Na QSC sobre milho transgênico $34(61,82 \%)$ dos estudantes relataram riscos à saúde, quatro $(7,27 \%)$ apresentaram riscos ao meio ambiente, $17(30,91 \%)$ não apresentaram argumento sobre risco e não houve argumentos insuficientes nem em branco/não opinaram. $\mathrm{Na}$ QSC sobre salmão transgênico $41(66,13 \%)$ relataram riscos à saúde, $11(17,74 \%)$ apresentaram riscos ao meio ambiente, sete $(11,29 \%)$ não apresentaram argumentos relativos a riscos e três $(4,84 \%)$ apresentaram argumentos insuficientes para categorização.

Quanto à consideração de riscos, identificou-se nos discursos dos estudantes riscos à saúde.

ENT.: Ok. E o que você entende por transgênicos? B16: É, tipo, modificado? É uma coisa geneticamente modificada. ENT.: Ok. Você é contra ou a favor a esses transgênicos? B16: Contra, porque esses alimentos, geralmente são alimentos, né, modificados? Acho que as vezes pode prejudicar a saúde da pessoa. (B16) Não, por que eu não sei a reação do organis mo. (C25)

Não, por que ele pode ser prejudicial à saúde, pois ele tem muitos hormônios e isso pode alterar de certa forma nosso organismo. (A7)

Discordo. O milho Bt traz muita riqueza para os agricultores, mas para nós seres humanos não, ele traz muitos malefícios a saúde. Então eu discordo o uso do milho Bt para consumo humano. (B13)

Também, encontrou-se discursos relativos aos riscos ao meio ambiente como desequilibrio ambiental, extinção de espécies (no caso do salmão transgênico) e o desenvolvimento de resistência dos insetos praga à toxina do milho Bacillus thuringiensis $(\mathrm{Bt})$.

Não, pois os argumentos contra estão totalmente certos, pois os peixes têm $40 \%$ mais hormônio, o que pode aumentar o risco de doenças, além que o peixe transgênico pode trazer o peixe natural a extinção. (B22)

Não, pois meu pensamento em relação aos danos ambientais são imutáveis, esses prejuízos são incalculáveis para o equilîbrio da fauna e da flora e pirâmide alimentar. (C18)

Não concordo. Entendo que ao longo do tempo a burrice humana em relação a falta de planejamento fez a população de humanos crescer demasiadamente e alterações na estrutura genética de alguns organismos tiveram que ser feitas para melhorar o rendimento etc. Mas, em minha opinião o ser humano não deveria tentar modificar processos naturais, pois os mesmos possuem seu equilibrio natural, qualquer alteração num indivíduo afeta toda a cadeia, pois a natureza é interdependente. Não se deve tentar alterar um sistema com bilhões de anos pela irresponsabilidade humana, mas fazer o quê?! (C18)

De acordo com os discursos percebeu-se que os estudantes apresentaram uma preocupação com os riscos relacionados ao meio ambiente e à saúde. As considerações sobre 
as consequências do uso de transgênicos sobre o meio ambiente e suas complexas interações, revelaram valores relacionados a sustentabilidade ambiental e a preservação da biodiversidade. Já em relação à saúde, os estudantes expressaram cuidado com o bem-estar e saúde.

Evidências empíricas apontam que os transgênicos podem ser prejudiciais à saúde humana, ao meio ambiente, à manutenção da biodiversidade e à preservação, regeneração e criação de agroecossistemas sustentáveis e produtivos, embora se espere que alguns deles só surgirão a longo prazo.

Os discursos apresentados por alguns estudantes permitiram uma categorização quanto a dimensão temporal dos riscos. As categorias emergentes nos discursos foram: risco a curto prazo, risco a longo prazo, sem argumento sobre risco a curto ou longo prazo, em branco/não opinou e argumento insuficiente para categorização.

$\mathrm{Na}$ entrevista quatro $(7,27 \%)$ estudantes relataram risco a curto prazo, quatro $(7,27 \%)$ relataram a longo prazo, nove (16,39\%) não apresentaram argumento que revelasse risco a curto ou longo prazo, 27 (49,09\%) não opinaram, três (5,45\%) apresentaram argumento insuficiente para a categorização. No questionário $14(25,45 \%)$ relataram risco a curto prazo, três $(5,45 \%)$ se referiram a risco a longo prazo, $19(34,55 \%)$ não apresentaram argumentos que expressassem risco a curto ou longo prazo, oito (14,55\%) deixaram em branco ou não opinaram e $11(20 \%)$ apresentaram argumentos insuficientes para categorizar.

No gráfico 6, na próxima página, são apresentados os dados referentes a distribuição da frequência das categorias referentes a dimensão temporal dos riscos relatados.

$\mathrm{Na}$ QSC sobre milho transgênico $22(40 \%)$ dos estudantes relataram risco a curto prazo, nove (16,36\%) expressaram risco a longo prazo, 22 (40\%) não apresentaram argumentos sobre riscos, um $(1,82 \%)$ deixou em branco ou não opinou e um $(1,82 \%)$ apresentou argumentos insuficientes. Na QSC sobre salmão transgênico $32(58,18 \%)$ dos estudantes relataram risco a curto prazo, dois $(3,64 \%)$ apresentaram risco a longo prazo, $18(32,73 \%)$ não expressaram a existência de riscos a curto nem a longo prazo e três $(5,45 \%)$ apresentaram argumentos insuficientes para categorização. 
Gráfico 6 - Distribuição da frequência de categorias relacionadas à dimensão temporal dos riscos

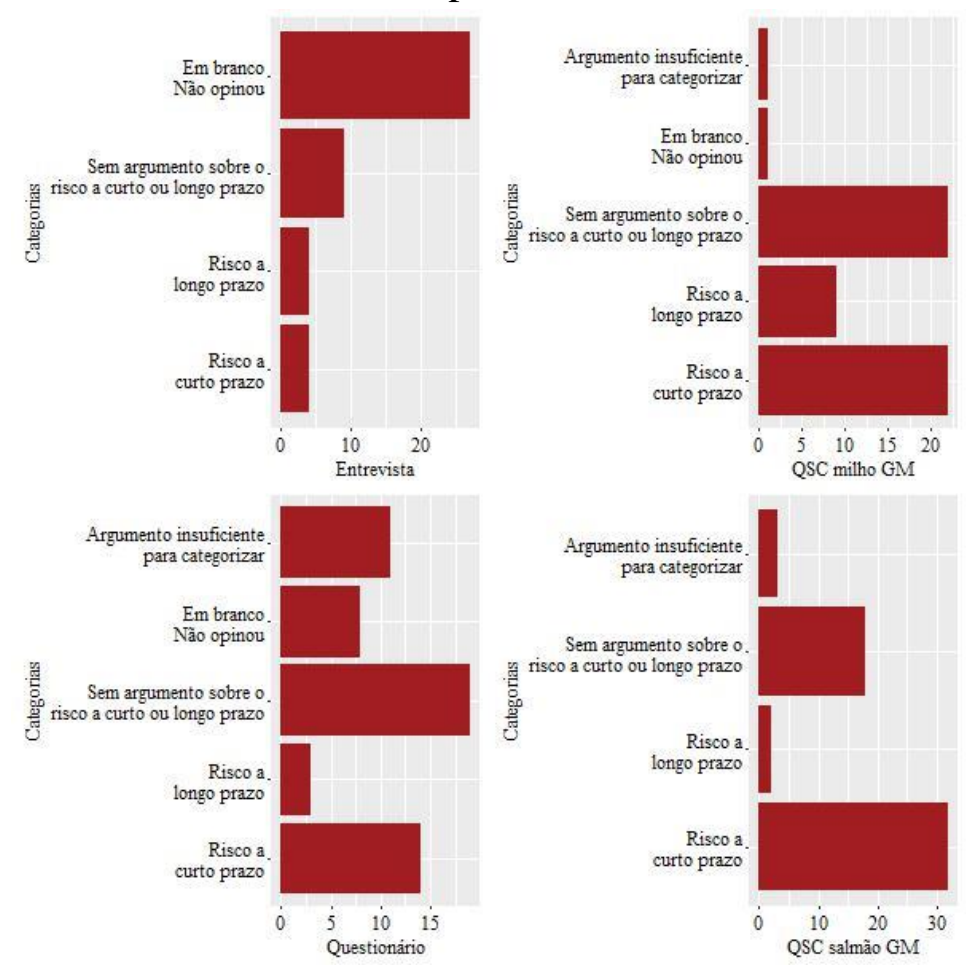

Fonte: elaboração da autora.

Percebeu-se que a categoria predominante no discurso dos estudantes que opinaram quanto a dimensão temporal dos riscos foi o risco a curto prazo.

Segundo Hottois (2005, p.101), tanto a humanidade quanto a filosofia sempre se preocuparam com as "gerações futuras", entretanto o entendimento sobre isso se estendia aos filhos e netos, não ultrapassando algumas dezenas de anos e sem a projeção de modificações essenciais.

O tema das gerações futuras tem voltado com insistência, mas ainda com ambiguidade e confusão como afirma (HOTTOIS, 2005). Essa importância deve-se ao fato do desenvolvimento da pesquisa e desenvolvimento tecnocientífico ter potencial para destruir ou modificar a natureza humana. Ainda, algumas ciências como a Biologia, a Geologia e a Cosmologia tem incentivado o uso de escalas temporais imensas, pensando no futuro do planeta e da própria espécie humana.

Hottois $(2005$, p.103) ainda sugere que a dificuldade para se pensar no longo prazo temporal pode ser devida a uma concepção centrada na ideia moderna de progresso de origem mítico-religiosa (Francis Bacon) e sua secularização. O autor ainda convida a reflexão para inverter essa perspectiva. Essa reflexão consiste em considerar "o curto e médio prazos levando 
em conta também a temporalização abissal que caracteriza em profundidade a questão atual do futuro da humanidade".

O ensino de Ciências deve incorporar considerações acerca da dimensão temporal dos riscos buscando promover uma reflexão do que seriam riscos a curto, médio e longo prazo, bem como as aplicações da biotecnologia podem afetar o futuro da humanidade.

Quanto aos riscos a curto prazo identificou-se nos discursos dos estudantes uma relação com a ocorrência de doenças de forma mais imediata, como alergias e indigestão.

Uhumm, tá. Transgênicos? ENT.: Você já ouviu falar? E1.: Já. São os alimentos modificados, né? ENT.: Sim, o que você acha sobre isso? Você concorda, é contra? E1: Concordo, justamente pelo fato se ele foi modificado foi para melhorar porque ninguém pega um alimento e modifica ele para ele ficar sem a vitamina, a não ser que ele tenha sido modificado para ficar sem essa vitamina porque haja pessoas que tenham alergia a essa vitamina ou que essa vitamina não esteja sendo bem utilizada pelo nosso organismo. (E1)

Não, por que esse tipo de alimento nos causará uma forte digestão, ou seja, desequilibrando o intestino e nos deixando mais imunes a certos tipos de doenças. (D2)

Discordo, pois o excesso de inseticida tem sido prejudicial à saúde. (B18)

Não. Como as informações citadas ele é muito prejudicial à saúde pelo fato dele conter muitos hormônios. (B13)

No caso dos riscos a longo prazo identificou-se uma preocupação com o futuro, todavia os estudantes não deixaram explícito a quanto tempo corresponde esse futuro.

ENT.: Transgênicos? B14: Transgênicos, ah, dos alimentos né? ENT.: Isso. B14: Que são geneticamente modificados. ENT.: Isso, são modificados geneticame nte. Você é a favor ou contra? B14: Contra. ENT.: Por quê? B14: Ah, como eu já tinha falado, é que muitas vezes a galera não sabe como, o que pode acontecer futuro com a gente. Então pode trazer um câncer esses alimentos, então não. (B14)

Não, por que não se sabe o que causará no futuro. (A1)

Concordo, pois ele aparentemente apresenta ter muito mais benefícios como uma melhor colheita, um tamanho maior, mas sem mudar seu valor nutricional. A única coisa que ainda me faz ter dúvidas é o fato de poder prejudicar a saúde a longo prazo. (B19)

Não, pois ainda é um novo recurso que não traz uma certeza do que realmente pode acontecer. (B24)

Realizou-se testes de hipótese para analisar se a percepção dos estudantes sobre o uso de transgênicos mudou após a realização do módulo sobre o referido tema. Os testes utilizados na análise foram McNemar e binomial.

Os testes foram aplicados sob as seguintes hipóteses: 
Ho: A oficina não mudou a percepção dos estudantes sobre o uso de alimentos transgênicos.

$\mathrm{H}_{1}$ : A oficina mudou a percepção dos estudantes sobre o uso de alimentos transgênicos.

As variáveis consideradas para o teste binomial foram: uso entrevista pré x uso milho transgênico, uso entrevista pré x uso salmão transgênico, decisão entrevista pré x decisão milho transgênico, decisão entrevista pré $\mathrm{x}$ decisão salmão transgênico, decisão questionário pré $\mathrm{x}$ decisão milho transgênico e decisão questionário pré x decisão salmão transgênico.

Após a realização dos testes acima descritos observou-se os p-valores e resultados apresentados no quadro 12. Nota-se que todos os valores encontrados para o p-valor foram maiores que o nível de significância estabelecido previamente, 5\%. Portanto, não há evidênc ias estatísticas para dizer se o módulo sobre transgênicos da oficina mudou a percepção dos estudantes quanto ao uso e decisão em relação aos alimentos transgênicos.

Quadro 12 - Resultados do teste binomial para os pares de variáve is em questão

\begin{tabular}{|l|c|c|}
\hline \multicolumn{1}{|c|}{ Testes } & p-valor & Decisão \\
\hline Uso entrevista X uso milho & 0,375 & Não é significativo \\
\hline Uso entrevista X uso salmão & 1 & Não é significativo \\
\hline Decisão entrevista X decisão milho & 1 & Não é significativo \\
\hline Decisão entrevista X decisão salmão & 1 & Não é significativo \\
\hline Decisão utilização X decisão milho & 0,1797 & Não é significativo \\
\hline Decisão utilização X decisão salmão & 0,375 & Não é significativo \\
\hline
\end{tabular}

Outro teste de hipóteses realizado foi o teste de McNemar, para as seguintes variáve is : uso questionário pré $\mathrm{X}$ uso milho transgênico e uso questionário pré $\mathrm{X}$ uso salmão transgênico. No quadro 13 são apresentados os p-valores e resultados do teste de McNemar.

Quadro 13 - Resultados do teste de McNemar para os pares de variáveis em questão

\begin{tabular}{|c|r|c|}
\hline Testes & \multicolumn{1}{|c|}{ p-valor } & \multicolumn{1}{c|}{ Decisão } \\
\hline Uso utilização X uso milho & 0,3428 & Não é significativo \\
\hline Uso utilização X uso salmão & 0,005546 & Significativo \\
\hline
\end{tabular}

Fonte: elaboração da autora. 
Percebeu-se que o p-valor do segundo teste está abaixo do nível de significância estabelecido, 5\%. Portanto, há evidências para dizer que a oficina mudou a percepção dos estudantes com relação à utilização do salmão transgênico na alimentação. Já para o milho transgênico o p-valor foi maior que o nível de significância estabelecido, portanto, não houve evidências estatísticas suficientes para dizer que a oficina mudou a percepção dos estudantes em relação ao uso do milho transgênico.

Além dos discursos referentes as análises realizadas, apresentamos outros que se destacaram por demonstrar grande confiança nos órgãos relacionados a regulação dos transgênicos, conforme o exemplo que se segue:

sim, primeiro por que o texto informa que o salmão transgênico contém as mesmas qualidades nutricionais do salmão comum, assim como também informa que tem mais hormônios, o que pode causar doenças, mas como é um alimento legal, perante leis, significa que não causa tantos, ou nenhum mal à saúde. (C11)

Outros, por sua vez, apresentaram descredito quanto aos órgãos de regulação.

Eu discordo, por que ainda não foi comprovado se pode ou não gerar danos a nossa saúde, e como o relatório é passado diretamente da empresa que distribui os variados tipos de alimentos transgênicos para o departamento que cuida desse processo, não temos certeza de que os alimentos transgênicos são seguros para o consumo. (D15)

Quanto a natureza da ciência um estudante considerou importante o estudo dos transgênicos e que os possíveis malefícios serão superados com o auxilio da pesquisa científica, demonstrando a crença de que a ciência pode resolver todos os problemas.

[...] ENT.: Você seria contra ou a favor? B24: Eu não, assim, eu acho que é certo o estudo disso, mas eu sei que pode ter algum, alguma coisa ruim, os efeitos colaterais disso. ENT.: Ok. B24: Mas eu acho interessante porque esses efeitos vão ser superados algum dia, eu acredito nisso. (B24)

Um dos problemas do ensino de Ciências, reside na ideia da Ciência como verdade inquestionável, que dificulta a compreensão do entendimento da natureza da atividade científica e impõe uma racionalidade instrumental que faz com que, muitas vezes, os professores sintamse responsáveis pela detenção das verdades definitivas que deverão transmitir aos estudantes (SCHEID; FERRARI, 2008). 
Ao contrário, alguns estudantes apontaram a necessidade de realização de mais pesquisas a fim de comprovar a existência ou não de riscos à saúde.

Concordo, mais ainda deve ser feito mais estudos sobre o assunto, e isso vai acontecer se houver investimentos, e não podemos deixar de lado que esses alimentos podem ser prejudiciais à saúde e que quem produz ele só se preocupa com os lucros. (B24)

Discordo, pois como a soja ele também é transgênico, ou seja, não tem estudos que comprovam que isso causará benefícios ou malefícios para seu futuro. No meu modo de pensar esses alimentos transgênicos tem que passar por um intenso processo de estudos assim como um remédio que para começar a ser vendido precisa passar por vários estudos e testes. (E12)

\section{C - Conhecimento sobre a biotecnologia}

A seguir, serão apresentados os resultados obtidos a partir da análise da categoria "conhecimento sobre a biotecnologia".

No gráfico 7 são apresentados os dados referentes à distribuição da frequência da categoria "conhecimento científico dos estudantes" antes da realização da SD.

Observou-se que dos 46 participantes 16 (34,78\%) souberam definir o que são transgênicos. Os outros $65,22 \%$ não souberam.

Gráfico 7 - Distribuição da frequência da categoria soube ou não definir o que são transgênicos antes da sequência didática

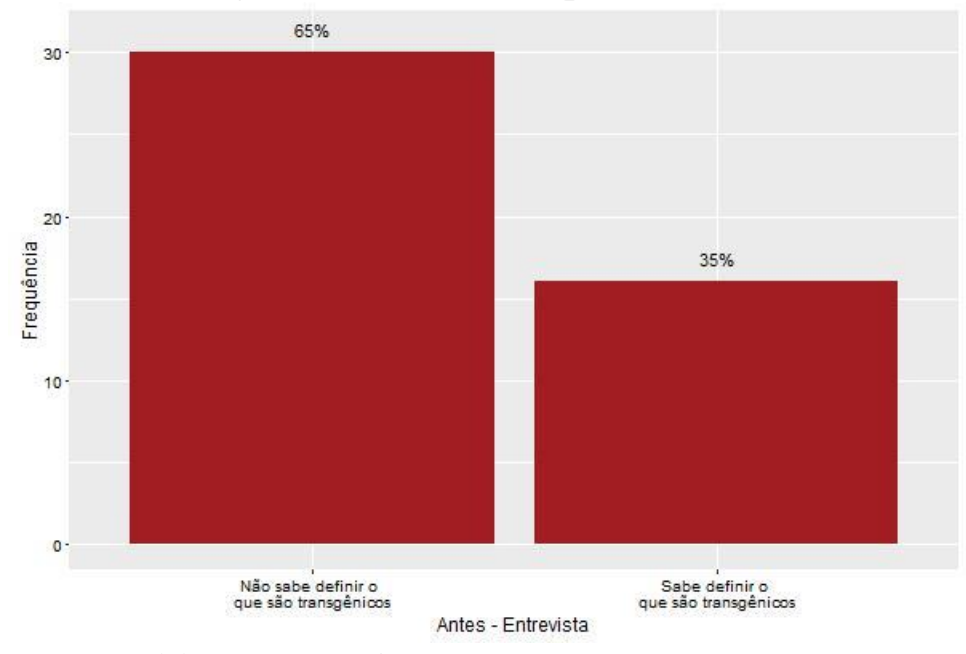

Fonte: elaboração própria.

Nesse estudo, uma das perguntas feitas aos estudantes por meio da entrevista visava caracterizar se eles sabiam o que são transgênicos. Com base nos resultados, percebeu-se que 
antes da realização da SD mais da metade dos estudantes não sabiam responder o que são transgênicos.

Sugere-se que as respostas iniciais dos estudantes foram apoiadas em concepções intuitivas e em alguns casos errôneas. Esses discursos demonstraram que os estudantes conseguem associar a transgenia à modificação genética, mesmo sem saber exatamente o que é. Observou-se também, que grande parte dos entrevistados se referiu aos transgênicos como sendo os alimentos.

ENT.: E sobre transgênicos? A1: Já. ENT.: Ou organismos geneticamente modificados? A1: Uhum. ENT.: O quê que cê sabe sobre eles? A1: São sementes? Sementes... A1: São geneticamente modificadas, que não sabe o que vai acarretar no futuro para quem come [...]. (A1)

ENT.: Ok, não tem problema que é desconhecido. $\mathrm{O}$ que você entende por transgênicos? B5: Transgênico eu entendo sobre os alimentos que você tá querendo dizer? ENT.: Pode ser. B5: Entendo sobre, que eles mudam a genética do alime nto para deixa-lo mais forte, mais bonito, que não possuam bactérias ou algum outro tipo de outro tipo de praga que possa atingir o alimento [...]. (B5)

ENT.: Ok. A gente vai ouvir então depois. Você já ouviu falar sobre transgênicos? B10: Isso eu já ouvi falar, até tava no questionário né? Alimentos transgênicos, mas agora... ENT.: Isso, o quê que você sabe? B10: Eu também não sei, não sei dizer o que seriam Alimentos Transgênicos. Deve, deve ser relacionado à modificação dos genes também né? Shirley: Isso, é modificação genética [...]. (B10)

ENT.: Perfeito. Vamos para nossa última pergunta dessa primeira rodada. O que você entende por transgênicos? C18: Transgênicos é um produto que foi geneticamente modificado né? ENT.: Perfeito. C18: E já tá tipo incorporado na nossa alimentação [...]. (C18)

ENT.: Mas enfim, vamos passar para próxima? Você sabe alguma coisa sobre transgênicos? Plantas transgênicas, alimentos transgênicos, animais? E2: Sim, que são geneticamente modificados, mas acho que para a melhoria. Porque tem vários tipos de opção, vários tipos de tomate, vários tipos de plantas, que elas são geneticamente modificadas e com melhoria para nutrição, a doenças também. Na verdade, para nutrir a gente. E a gente também já come produtos que são transgênicos [...]. (E2)

Esses dados corroboram com os das pesquisas realizadas por Durbano et al. (2008) e Pedrancini et al. (2008) onde a maior parte dos estudantes definiram transgênicos de forma superficial, intuitiva e, às vezes, incorreta.

As respostas intuitivas podem estar relacionadas à falta de conhecimento dos estudantes na conceituação do termo transgênico, haja vista que os mesmos podem ter definido o conceito a partir do conhecimento veiculado pelos meios de comunicação, livros didáticos ou até mesmo por terem visto de forma superficial em sala de aula. Além disso, como o tema em questão está ligado a controvérsias e polarização de opiniões, muitas vezes os estudantes não 
conseguem formar uma opinião própria, devido à falta de conhecimento constituído de maneira mais sólida.

ENT:: O que você entende por transgênicos? B18: Transgênicos é uma mutação que tal alimento sofre, pelo que eu já aprendi. ENT.: Ok, perfeito. E você é contra ou a favor o transgênico? B18: Olha, eu não tenho uma opinião formada, porque pelo o que me explicaram dos transgênicos eu não entendi muito bem e não sei se ele é a favor ou contra a nossa saúde. (B18)

Nem sempre o ensino promovido na escola cria um ambiente onde o estudante possa participar ativamente da construção do conhecimento. Para tanto, é necessário propiciar situações que permitam ao estudante exporem suas percepções, questionamentos e, assim, desenvolverem uma postura crítica frente ao tema. O ensino de Biologia deve ir além dos conteúdos, e propiciar a construção de conhecimento que auxilie o estudante a compreender melhor o mundo que o cerca.

Apesar desse tema estar presente no currículo escolar, muitas vezes ele não é abordado. Algumas razões contribuem para isso, como: falta de tempo, currículo extenso e por insegurança ou despreparo do professor. Somado a isso, tanto professores quanto estudantes consideram esse tema difícil e abstrato levando a um desinteresse na abordagem do tema por parte dos professores e na audiência dos estudantes nessas aulas.

No gráfico 8, na próxima página, é apresentada a distribuição da frequência de estudantes quanto as categorias de incorporação do conhecimento científico nas QSC milho e salmão transgênico.

Após a SD 84,78\% dos estudantes fizeram referência ao conteúdo ensinado quando perguntados sobre o milho transgênico e 78,26\% quando perguntados sobre o salmão transgênico. Em ambos os questionamentos sobre os alimentos transgênicos apenas 6,52\% apresentaram alguma crítica ou reflexão. Com relação ao salmão transgênico 8,7\% não fez referência ao conteúdo ensinado e 4,35\% não fizeram referência ao conteúdo ensinado quando perguntados sobre o milho transgênico, 4,35\% incorporaram outros conhecimentos ao responder à questão sobre o milho transgênico e 6,52 \% no caso salmão transgênico. 
Gráfico 8 - Distribuição da frequência relacionada às categorias de incorporação do conhecimento científico dos estudantes em relação ao milho e salmão transgênicos

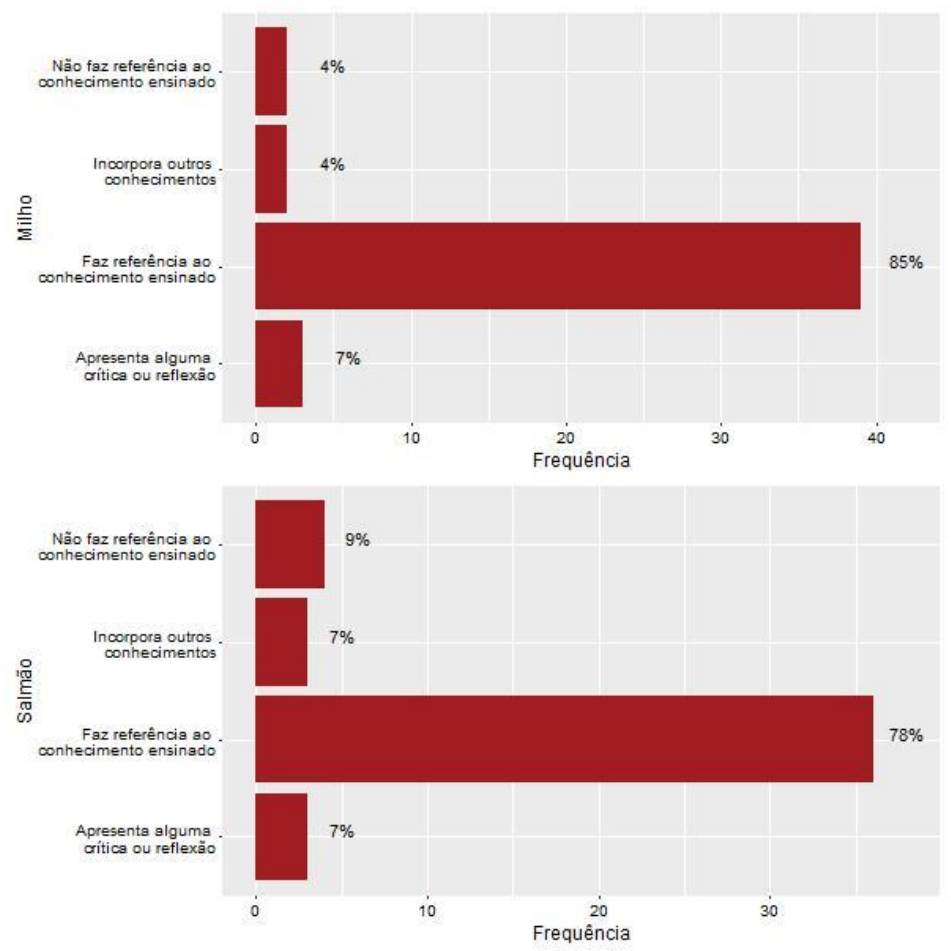

Fonte: elaboração da autora.

Com base nesses resultados percebeu-se uma maior incorporação do conhecimento ensinado na justificativa das questões sobre o milho e o salmão transgênico. Especificamente, na QSC sobre o salmão transgênico foi incluído um pequeno texto apontando os prós e contra da produção/utilização desse transgênico, mesmo assim, 8,7\% dos estudantes não utilizaram esse conhecimento para apoiarem suas decisões.

Após as atividades em sala de aula, houve uma diminuição de conceitos equivocados, mas eles ainda apareceram. Cabe ressaltar que alguns estudantes não souberam opinar, mesmo após a participação das atividades em sala de aula.

Dawson e Schibeci (2003) revelam que a preocupação dos educadores quanto a percepção dos riscos da tecnologia está em saber se essas percepções estão sujeitas a maturação ao longo do tempo e, como isso, a modificação no comportamento e tomada de decisão dos estudantes sobre questões de ciência e tecnologia. Entretanto, os autores reconhecem que essa questão não é clara, pois sabe-se que a ausência de conhecimento sobre uma tecnologia específica não impede a formação de atitudes ou percepções (LEE et al., 2005). Por outro lado, atitudes e percepções, podem estar associadas a crenças e valores pessoais e, por isso, são mais resistentes à mudança (DAWSON; SCHIBECI, 2003). 
Como vemos, a literatura sobre o assunto aponta que a relação entre o conhecimento científico e a atitude relacionada a biotecnologia é complexa. Alguns estudos têm demonstrado que pessoas com uma sólida base de conhecimentos possuem mais facilidade para expressar seu ponto de vista, independentemente de serem positivos ou negativos sobre questões relacionadas à tecnologia genética (JALLINOJA e ARO, 2000).

Sadler e Zeidler (2005) analisaram os efeitos do conhecimento de genética sobre os padrões e a qualidade do raciocínio informal relacionado a questões de engenharia genética. Os participantes com maior domínio do conteúdo demonstraram uma melhor qualidade de raciocínio, e eram mais propensos a incorporar o conhecimento em seus padrões de raciocínio do que os participantes com uma compreensão mais ingênua de genética.

Os discursos referentes à categoria "não faz referência ao conhecimento ensinado", mostraram uma compreensão superficial, intuitiva e, às vezes, incorreta do tema em questão.

Eu discordo, mas querendo ou não sempre vamos acabar consumindo transgênico, pois está por toda parte, além de que é muito dificil achar alimentos "puros" que não contém a química dos transgênicos. (A15)

Sim, o maior malefício causado por uma grande quantidade é uma dor no estômago. Si retirado do mercado a quantidade de salmão vai cair de um modo alarmante. (E2)

Nos discursos relacionados à categoria "faz referência ao conhecimento ensinado", percebeu-se que após as atividades em sala de aula, houve uma apropriação do que foi ensinado, por exemplo, alguns estudantes souberam relacionar que a diminuição de agrotóxicos no milho transgênico reduz o impacto ambiental e provoca um aumento na produção causando um impacto financeiro positivo.

Eu discordo, pois, o milho Bt apresenta vantagens no aumento da produção, financeiramente, no impacto ambiental. Porém o número de pragas irá aumentar e o mais importante os riscos à saúde, os estudos não são conclusivos sobre a saúde, mais provavelmente deve ter. E o mais importante para mim, primeiro é a saúde apesar de uma economia também é importante. (B7)

Outro estudante se referiu ao fato desses alimentos poderem causar danos à saúde e que quem detém as vantagens sobre esse tipo de produto é o agrobusiness:

concordo, mais ainda deve ser feito mais estudos sobre o assunto, e isso vai acontecer se houver investimentos, e não podemos deixar de lado que esses alimentos podem ser prejudiciais à saúde e que quem produz ele só se preocupa com os lucros. (B24) 
Quanto a incorporação de outros conhecimentos percebeu-se a presença de conteúdos de ecologia acerca da interdependência das espécies e do equilíbrio ecossistêmico.

Não concordo. Entendo que ao longo do tempo a burrice humana em relação a falta de planejamento fez a população de humanos crescer demasiadamente e alterações na estrutura genética de alguns organismos tiveram que ser feitas para melhorar o rendimento etc. Mas, em minha opinião o ser humano não deveria tentar modificar processos naturais, pois os mesmos possuem seu equilibrio natural, qualquer alteração num indivíduo afeta toda a cadeia, pois a natureza é interdependente. Não se deve tentar alterar um sistema com bilhões de anos pela irresponsabilidade humana, mas fazer o quê?! (C18)

No caso do salmão transgênico o estudante, também utilizou conhecimentos de ecologia para justificar sua decisão: "O salmão como todos os outros peixes precisam de um predador para manter a teia alimentar se os salmões forem feitos transgenicamente esses peixes vão quebrar a teia alimentar e traria um desequilíbrio para todo o resto dos peixes, por isso sou contra o salmão transgênico. (E12)

Alguns estudantes apresentaram uma crítica ou reflexão. Por exemplo, o estudante a seguir teceu uma crítica em relação a produção de transgênicos apontando que eles podem ter um efeito sobre o organismo e que a sua produção está relacionada apenas aos lucros.

Não, sou contra o consumo de transgênicos, apesar de que em nossa sociedade tudo o que compramos é transgênico. Se pararmos para pensar estamos consumindo, de certa forma, milho com inseticida, isso tem um efeito sobre nosso corpo, mesmo que tardio. Alimentos transgênicos são um golpe capitalista, mais produção representa mais dinheiro, e os transgênicos são mais dinheiro. (B14)

Outro estudante, também apresentou um discurso que revelou uma crítica as empresas responsáveis pela produção dos transgênicos como as detentoras dos lucros e os danos que eles podem causar a saúde e ao meio ambiente.

Não. Existem alguns prós, porém em minha opinião, não vale a apena consumir algo que leve a um desequilibrio natural e possa trazer doenças (de maneira mais fácil). Além disso, os prós citados valem muito mais para uma empresa, com sede capitalista, do que para um consumidor, sendo que um salmão comum possui as mesmas qualidades nutricionais, e os recursos "preservados" citados no texto fazem parte de um ciclo natural da vida, assim eles se renovam. Com o tempo, um salmão modificado geraria um desequilibrio, ou seja, esse "pró" citado no gráfico é um contra. (B14)

No quadro 14 são apresentados alguns discursos antes e depois da SD que revelam a apropriação do conhecimento científico pelos estudantes para justificar a tomada de decisão. 
Quadro 14-Exemplos de discursos de estudantes antes e depois do módulo sobre transgênicos

\begin{tabular}{|c|c|c|}
\hline Ante da oficina & \multicolumn{2}{|c|}{ Depois da oficina } \\
\hline Entrevista & Milho transgênico & Salmão transgênico \\
\hline $\begin{array}{l}\text { ENT.: Ok, não tem problema } \\
\text { por ser desconhecido. E o que } \\
\text { você entende portrans gênicos? } \\
\text { B7: Eu não sei nada de } \\
\text { biologia. (B7) }\end{array}$ & $\begin{array}{l}\text { Eu discordo, pois, o milho Bt apresenta } \\
\text { vantagens no aumento da produção, } \\
\text { financeiramente, no impacto ambiental. } \\
\text { Porém o número de pragas irá aumentar e } \\
\text { o mais importante os riscos à saúde, os } \\
\text { estudos não são conclusivos sobre a } \\
\text { saúde, mais provavelmente deve ter. E o } \\
\text { mais importante para mim, primeiro é a } \\
\text { saúde apesarde uma economia também é } \\
\text { importante. (B7) }\end{array}$ & $\begin{array}{l}\text { Não, pois estudos dizem que a alta } \\
\text { quantidade de hormônios } \\
\text { encontrado no salmão é prejudicial } \\
\text { à saúde. E o que está relacionado a } \\
\text { riscos à saúde não me interessa. } \\
\text { (B7) }\end{array}$ \\
\hline $\begin{array}{l}\text { ENT.: Transgênicos? B14: } \\
\text { Transgênicos, ah, dos } \\
\text { alimentos né? ENT.: Isso. B14: } \\
\text { Que são geneticamente } \\
\text { modificados. ENT.: Isso, são } \\
\text { modificados geneticamente. } \\
\text { Você é a favor ou contra? B14: } \\
\text { Contra. ENT.: Por quê? B14: } \\
\text { Ah, como eu já tinha falado, é } \\
\text { que muitas vezes a galera não } \\
\text { sabe como, o que pode } \\
\text { acontecer futuro com a gente. } \\
\text { Então pode trazer um câncer } \\
\text { esses alimentos, então não. } \\
\text { (B14) }\end{array}$ & $\begin{array}{l}\text { Não, sou contra o consumo de } \\
\text { transgênicos, apesar de que em nossa } \\
\text { sociedade tudo o que compramos é } \\
\text { transgênico. Se pararmos para pensar } \\
\text { estamos consumindo, de certa forma, } \\
\text { milho com inseticida, isso tem um efeito } \\
\text { sobre nosso corpo, mesmo que tardio. } \\
\text { Alimentos transgênicos são um golpe } \\
\text { capitalista, mais produção representa } \\
\text { mais dinheiro, e os transgênicos são mais } \\
\text { dinheiro. (B14) }\end{array}$ & $\begin{array}{l}\text { Não. Existem alguns prós, porém } \\
\text { em minha opinião, não vale a } \\
\text { apena consumir algo que leve a um } \\
\text { desequilíbrio naturale possa trazer } \\
\text { doenças (de maneira mais fácil). } \\
\text { Além disso, os prós citados valem } \\
\text { muito mais para uma empresa, } \\
\text { com sede capitalista, do que para } \\
\text { um consumidor, sendo que um } \\
\text { salmão comum possui as mesmas } \\
\text { qualidades nutricionais, e os } \\
\text { recursos "preservados" citados no } \\
\text { texto fazem parte de um ciclo } \\
\text { natural da vida, assim eles se } \\
\text { renovam. Com o tempo, um } \\
\text { salmão modificado geraria um } \\
\text { desequilíbrio, ou seja, esse "pró" } \\
\text { citado no gráfico é um contra. } \\
\text { (B14) }\end{array}$ \\
\hline $\begin{array}{l}\text { ENT.: E transgênicos, você já } \\
\text { ouviu falar? Alimentos } \\
\text { transgênicos ou organismos } \\
\text { geneticamente modificados? } \\
\text { C11: Já, mas nunca vi assim } \\
\text { algo específico. (C11) }\end{array}$ & $\begin{array}{l}\text { Concordo ele pode se tornar um grande } \\
\text { aliado no futuro para a agricultura e para } \\
\text { uma melhor produção desse milho, os } \\
\text { alimentos transgênicos vieram para o } \\
\text { benefício da população. (C11) }\end{array}$ & $\begin{array}{l}\text { Sim, primeiro por que o texto } \\
\text { informa que o salmão trans gênico } \\
\text { contém as mesmas qualidades } \\
\text { nutricionais do salmão comum, } \\
\text { assim como também informa que } \\
\text { tem mais hormônios, o que pode } \\
\text { causar doenças, mas como é um } \\
\text { alimento legal, perante leis, } \\
\text { significa que não causa tantos, ou } \\
\text { nenhum mal à saúde. (C11) }\end{array}$ \\
\hline $\begin{array}{l}\text { ENT.: Sem problema. E o que } \\
\text { você entende por trans gênicos? } \\
\text { E5: Transgênicos? ENT.: O } \\
\text { que te vem à mente quando fala } \\
\text { transgênicos? Você lembra } \\
\text { alguma coisa? E5: Tô tentando } \\
\text { lembrar alguma coisa... ENT.: } \\
\text { O que você entende por } \\
\text { transgênicos então? E5: Eu não } \\
\text { lembro. (E5) }\end{array}$ & $\begin{array}{l}\text { Sim, pois eles podem diminuir os danos } \\
\text { causados porinsetos praga. (E5) }\end{array}$ & $\begin{array}{l}\text { Não, por que ele pode trazer riscos } \\
\text { e ser muito prejudicial à saúde, por } \\
\text { conta dos hormônios encontrados } \\
\text { no peixe. (E5) }\end{array}$ \\
\hline
\end{tabular}

Fonte: elaboração da autora. 
A partir dos resultados percebeu-se a necessidade da incorporação de informações atualizadas e materiais relacionados as aplicações da biotecnologia, além de propiciar discussões e debates com vistas a construção de uma consciência crítica e reflexiva sobre o tema. Consideramos que quanto mais qualificada for a discussão maior será a informação dos estudantes e sua atuação como cidadãos para exigirem políticas reguladoras de produção que visem a proteção da sociedade e do meio ambiente.

\section{D - Cons ciência ecológica}

A terceira categoria analisada foi a consciência ecológica. Abaixo seguem os resultados da análise descritiva e dos testes de hipótese.

No gráfico 9 são apresentados os dados de distribuição da frequência das categorias relacionadas a consciência ecológica.

Gráfico 9 - Distribuição da frequência das categorias relacionadas à consciência ecológica dos estudantes por instrumento analisado

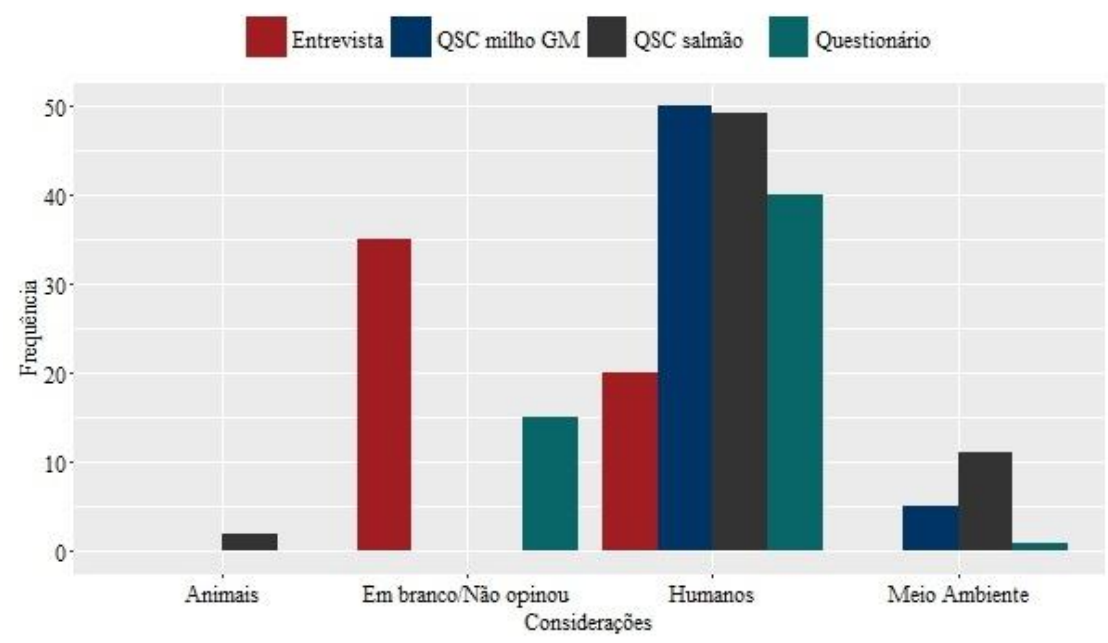

Fonte: elaboração da autora.

Na entrevista 20 de $55(36,4 \%)$ dos estudantes apresentaram considerações sobre seres humanos, não houve considerações sobre animais sencientes nem sobre o meio ambiente, 35 de $55(63,6 \%)$ não opinaram. No questionário 40 de $56(71,4 \%)$ apresentaram considerações sobre os seres humanos, não houve considerações sobre os seres sencientes nem sobre o meio ambiente, 15 de $56(26,8 \%)$ deixaram em branco ou não opinaram.

Na QSC milho transgênico 50 de 55 (90,9\%) apresentaram considerações sobre os seres humanos, não houve considerações sobre os animais, cinco de $55(9,1 \%)$ apresentaram considerações sobre o meio ambiente e não houve questões em branco/não opinaram. Na QSC 
salmão transgênico 49 de 62 (79\%) apresentaram considerações sobre seres humanos, dois $(3,2 \%)$ apresentaram considerações sobre os animais, $11(17,7 \%)$ apresentaram considerações sobre o meio ambiente e não houve questões em branco/não opinou.

A partir da análise dos dados percebeu-se que, após o módulo sobre transgênicos, a frequência de considerações sobre os seres humanos e o meio ambiente aumentou.

Nos instrumentos aplicados antes da SD a quantidade de estudantes que deixaram em branco ou não opinaram foi elevada e, posteriormente reduzida nos instrumentos utilizados após a SD.

Grace e Ratcliffe (2002) observaram em um estudo sobre conservação biológica que os estudantes expressaram mais os valores antropocêntricos como: estética/prazer, custo/benefício, altruísmo/geração futura e segurança. Para Grace e Ratcliffe (2002, p.1167, tradução da autora) "a concorrência entre organismos é um conceito científico; competição entre os animais e os seres humanos é uma questão de valores, dependentes do ponto de vista biocêntrico-antropocêntrico". Ainda, segundo os autores, os estudantes podem se envolver na tomada de decisão sobre questões de conservação, mas o uso de valores e conceitos científicos é dependente do contexto. Sendo assim, os autores indicam a necessidade de discutir uma série de cenários, a fim de maximizar o entendimento, acerca da complexidade envolvida nesse assunto.

Sadler (2004b) afirmou que mais de três quartos dos participantes de um estudo estavam preocupados com a vida, a saúde e o bem-estar de outros seres humanos.

Na categoria "considerações apenas sobre seres humanos" os discursos revelaram uma preocupação voltada a valores antropocêntricos como a saúde humana e não consideraram nem os animais nem o meio ambiente.

Sim, pois estudos comprovado que eles estão ligados a uma saúde melhor. A16 Discordo, pois o uso dessas bactérias nos alimentos pode causar sérios problemas para os humanos no futuro. (B5)

Compraria, desde que não afete minha saúde. (C16)

$\mathrm{Na}$ categoria "considerações sobre os animais sencientes" alguns estudantes apresentaram valores voltados a proteção dos animais.

Não, acho que o que eles fazem com o salmão é crueldade, pois eles não podem viver livremente, se reproduzir, só são feitos para crescer. (D5)

Não, por que eu não concordo com o nascimento de nenhum animal rápido, eu acho que cada um deve ter seu tempo para nascer, eu não compraria. (D1) 
Alguns estudantes apresentaram considerações sobre o meio ambiente.

Se antes do melhor transgênico ser introduzido no Brasil eu discordaria de primeira, mas como ele já foi introduzido no Brasil e querendo ou não ele está no nosso dia a dia e ficaria bem difícil tirar ele dos mercados e das vidas das pessoas. Só que ainda não posso dizer se concordo ou discordo por que ele traz muitos benefícios, mas também traz muitos malefícios. E não adiante tentar melhorar uma coisa e estragar o mais importante que é o nosso meio ambiente. (A25)

Não, pois o consumo desse tipo de salmão apenas favorece ainda mais o seu cultivo. o problema é o fato dele possuir grandes taxas hormonais que podem afetar diretamente nossa saúde futuramente. Sua existência é uma ameaça às espécies naturais, portanto, se eu tivesse a oportunidade de escolher, compraria o natural ao invés do modificado. (B10)

Não, pois meu pensamento em relação aos danos ambientais são imutáveis, esses prejuízos são incalculáveis para o equilibrio da fauna e da flora e pirâmide alimentar. (C18)

Foram realizados quatro testes de hipóteses para verificar se os estudantes modificaram ou não a sua consciência ecológica (CE) por meio da oficina em relação ao uso de alimentos transgênicos. O teste escolhido para realizar essa análise foi o teste de McNemar.

Os testes foram realizados em relação a categoria $\mathrm{CE}$ e aos seguintes instrumentos: $\mathrm{CE}$ entrevista pré $\mathrm{x} \mathrm{CE}$ milho transgênico, $\mathrm{CE}$ entrevista pré $\mathrm{x} \mathrm{CE}$ salmão transgênico, $\mathrm{CE}$ questionário pré x CE milho transgênico e CE questionário pré x CE salmão transgênico.

O teste foi aplicado sob as seguintes hipóteses:

$\mathrm{H}_{0}$ : A oficina não mudou a consciência ecológica dos estudantes.

$\mathrm{H}_{1}$ : A oficina mudou a consciência ecológica dos estudantes.

Após a realização dos testes explicitados acima sob as hipóteses descritas, obteve-se os p-valores apresentados no quadro 15 .

Quadro 15 - P-valores dos testes realizados

\begin{tabular}{c|c|c|c|c}
\hline \multicolumn{1}{c|}{ Testes } & Estatística & p-valor & Decisão & \\
\hline Entrevista x Milho & 33,029 & $<0,0001$ & Significativo & \\
\hline Entrevista x Salmão & 33,029 & $<0,0001$ & Significativo & \\
\hline Utilização x Milho & 13,067 & 0,0003 & Significativo & \\
\hline Utilização x Salmão & 13,067 & 0,0003 & Significativo & \\
\hline
\end{tabular}

Fonte: elaboração da autora.

Notou-se pela tabela acima, que nenhum p-valor obtido foi maior ou igual ao nível de significância previamente estabelecido, igual a 5\%. Ou seja, a hipótese nula, $\mathrm{H}_{0}$, foi rejeitada 
em todos os testes. Portanto, há evidências estatísticas suficientes para afirmar que a oficina modificou a percepção dos estudantes sobre a consciência ecológica.

\section{E - Domínio moral}

Segue-se a análise das categorias emergentes nos discursos dos estudantes quanto aos aspectos morais. Os dados serão apresentados, por meio de gráficos, obtidos das considerações morais dos estudantes nos quatro instrumentos analisados, entrevista, questionário, QSC milho e salmão transgênico.

No gráfico 10 são apresentados os dados da frequência de consideração moral, não moral e em branco/não opinou por instrumento utilizado.

Gráfico 10 - Distribuição da frequência de considerações do domínio moral, não moral e em branco dos estudantes segundo os instrumentos utilizados

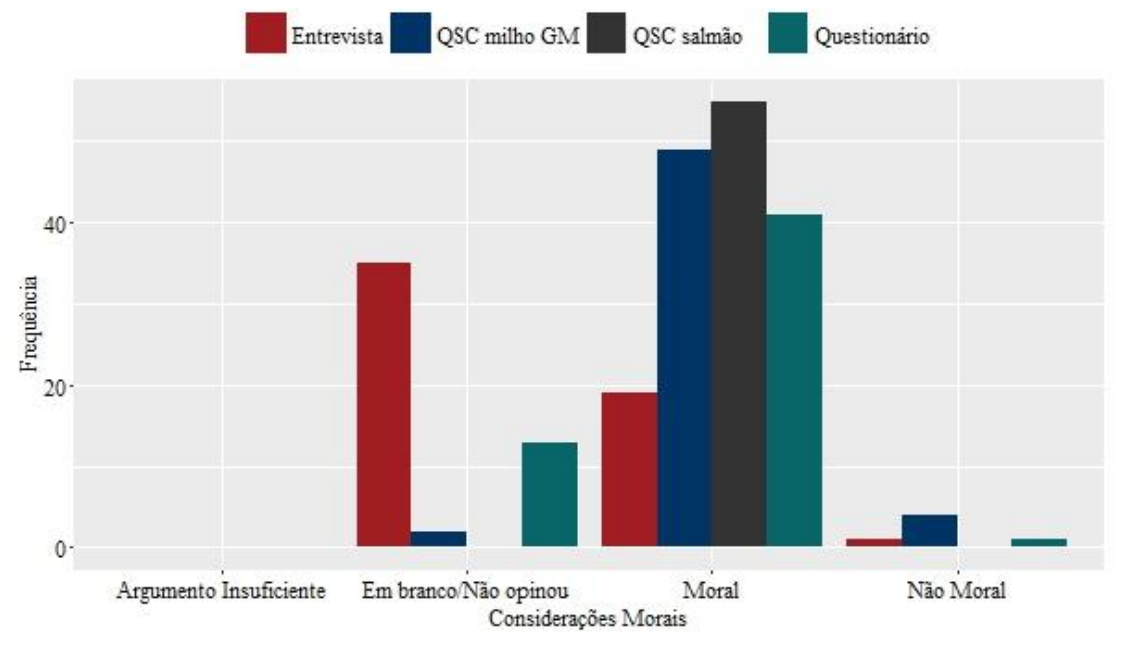

Fonte: elaboração própria.

$\mathrm{Na}$ entrevista 19 de 55 (34,5\%) dos estudantes apresentaram considerações relacionadas ao domínio moral, um $(1,8 \%)$ não apresentou consideração do domínio moral e 35 de 55 (não opinaram). No questionário, 41 de 55 (74,5\%) apresentaram considerações do domínio moral, um (1,8\%) apresentou consideração não moral e $13(23,6 \%)$ deixaram em branco/não opinaram.

Na QSC milho transgênico $49(89,1 \%)$ apresentaram considerações do domínio moral, quatro $(7,3 \%)$ expressaram considerações não moral, dois $(3,6 \%)$ deixaram em branco/não opinaram. Na QSC salmão transgênico, 55 (100\%) apresentaram considerações do domínio moral. 
Observou-se que na maioria dos casos os estudantes interpretam questões sobre os alimentos transgênicos com base em considerações morais. Pesquisas da área de ensino de Ciências têm apresentado evidências de que os processos de tomada de decisão envolvendo QSC são guiados, além do conhecimento científico, por fatores sociais, morais e afetivos (ver, por exemplo, FOWLER; ZEIDLER; SADLER, 2009; MUELLER; ZEIDLER, 2010; SADLER; FOWLER, 2006; SADLER, 2004a e b; WALKER; ZEIDLER, 2007; ZEIDLER; KEEFER, 2003).

Nucci (2000) distingue moralidade de convenção social, associando sua definição à justiça, ao bem-estar e aos direitos. Nos discursos abaixo, percebeu-se que os estudantes utilizaram considerações do domínio moral relacionadas ao bem-estar.

ENT.: E alimentos transgênicos, organismos transgênicos? E12: Já. São feitos em laboratório, são geneticamente alterados. ENT.: Isso, são alterados. Você concorda com... E12 Não, porque, porque você não sabe o quê que vai acontecer no futuro. Tipo, se isso vai fazer mal ou se vai fazer bem, aí você não sabe, só com o tempo. (E12)

Não, faz mal as pessoas. (B13)

Discordo, pois os malefícios podem ser prejudiciais além de o custo de venda não reduzir para os consumidores. (E15)

Alguns estudantes apresentaram discursos que foram categorizados como não moral como no exemplo a seguir:

eu concordo mais acho que deveria ter especificações do que é transgênico e haver a separação do que não é transgênico no mercado, por que muitas pessoas não sabem o que é. (E6)

\section{F - Julgamento moral}

O gráfico 11 apresenta dos dados relativos a distribuição da frequência dos tipos de consideração moral dos estudantes. 
Gráfico 11 - Distribuição da frequência de moral deontológica, utilitarista e ceticismo moral dos estudantes

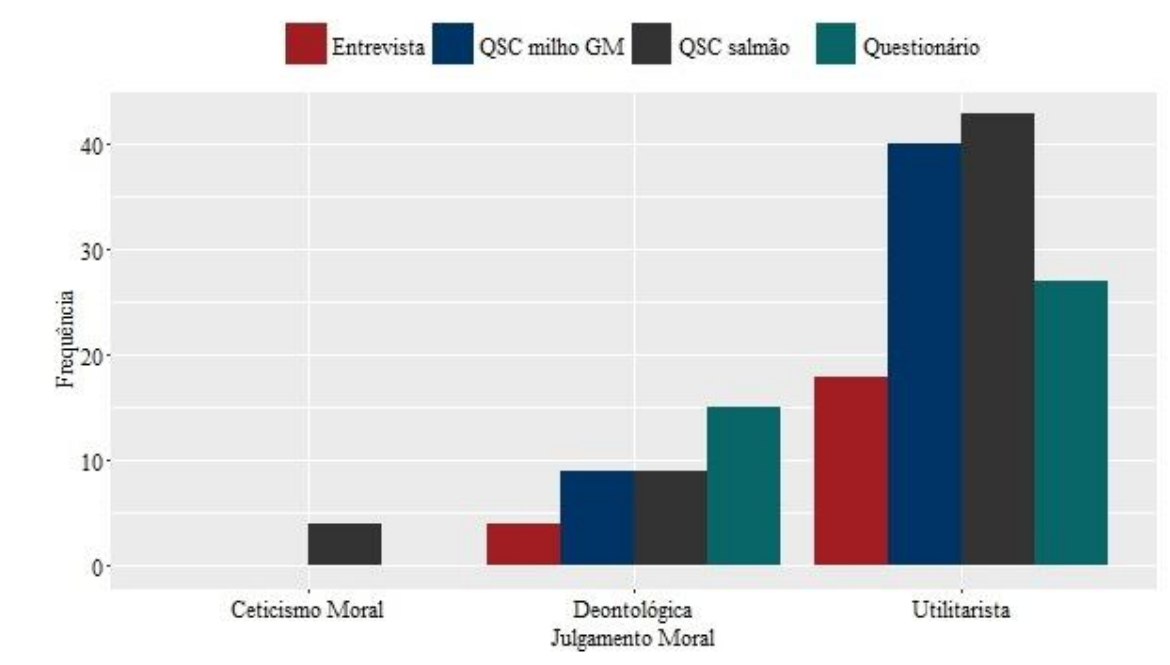

Fonte: elaboração da autora.

$\mathrm{Na}$ entrevista quatro $(18,2 \%)$ apresentaram moral deontológica, 18 (81,8\%) expressaram moral utilitarista e nenhum estudante expressou ceticismo moral. No questionário $15(35,7 \%)$ apresentaram moral deontológica, $27(64,3 \%)$ e nenhum dos estudantes expressou ceticismo moral.

Na QSC milho transgênico nove (18,4\%) expressaram moral deontológica, 40 (81,6\%) apresentaram moral utilitarista, nenhum estudante expressou ceticismo moral. Na QSC salmão transgênico nove $(16,1 \%)$ apresentaram moral deontológica, 43 (76,8\%) expressaram moral utilitarista e quatro $(7,1 \%)$ apresentaram ceticismo moral.

Observou-se que as considerações morais utilitaristas foram consideravelmente superiores as demais em todos os instrumentos analisados. Houve um aumento na frequência dessa variável na QSC milho e salmão transgênico. Assim, conclui-se que a maioria dos casos os estudantes interpretam questões sobre os alimentos transgênicos com base na moral utilitarista.

Esse dado corrobora com o encontrado por Reiss (2008) que após um curso para estudantes de 16-18 anos de idade, no qual foram introduzidos quadros éticos baseados em direitos e deveres, autonomia e virtude ética, verificou que o raciocínio ético utilitarista é amplamente utilizado e que os outros quadros éticos foram usados com menos frequência.

Considera-se que no contexto educacional, a teoria teleológica, sobretudo, a vertente utilitarista, é a que melhor se ajusta, por mobilizar o raciocínio dedutivo dos estudantes e requerer uma maior reflexão, uma vez que a tomada de decisão e as ações têm como parâmetro o cálculo, os meios e os fins. Nesse caso, a decisão se vale dos resultados, das consequências 
esperadas e do resultado da decisão. Lembrando que o princípio básico da moral utilitarista é o alcance do bem maior para a maioria e que as normas não têm um fim em si. Isso não significa a eliminação de normas ou códigos, mas que, de fato, além de serem explícitos para serem úteis devem permitir espaço para que os estudantes julguem situações. O que requer maior responsabilidade dos estudantes para tomar decisões morais. Ao contrário da ética deontológica que se baseia em normas estabelecidas aprioristicamente considerando apenas a intenção do ato, não o resultado.

Sob a ótica da moral utilitarista, como a própria teoria sustenta: o bem, o valor, o útil e o funcional é o melhor resultado para a maioria. Contudo, é necessário que o professor mostre aos estudantes os limites do utilitarismo demonstrando que esse pode contribuir para a eficiência, porém também poderá desrespeitar direitos individuais, em especial, das minorias, como alerta Sen (2000) ao apresentar os limites do utilitarismo. Entretanto, o próprio autor aponta que essa é a teoria ética predominante na sustentação do estado de bem-estar.

A seguir serão apresentados exemplos de discurso moral deontológico, utilitarista e ceticismo moral.

Moral deontológica

ENT.: Você é contra ou a favor dos transgênicos? C18: Olha, eu sou meio dúbio nessa questão, mas eu acho que eu sou mais contra do que a favor. ENT.: Ok, por quê que você é mais contra? C18: Não sei, porque eu acho que o natural, o natural é sempre melhor, né? ENT.: Perfeito. C18: O natural alimento. (C18) Sim, por que a maioria dos alimentos que como são praticamente alterados. (A8) $\mathrm{Eu}$ acho que os humanos não deviam se meter no ciclo da natureza mesmo sendo com boas intenções, isso pode levar a um desequilibrio ambiental, eu sou contra. (C15)

Sim, primeiro por que o texto informa que o salmão transgênico contém as mesmas qualidades nutricionais do salmão comum, assim como também informa que tem mais hormônios, o que pode causar doenças, mas como é um alimento legal, perante leis, significa que não causa tantos, ou nenhum mal à saúde. (C11)

\section{$\underline{\text { Moral utilitarista }}$}

Tudo bem, vamos para a próxima. Transgênicos? Você já ouviu falar, não já? Já, são coisas modificadas. Exatamente. Você é a favor ou contra? Contra. Contra, por que? Normalmente eles mudam muito os alimentos, e a gente deveria comer coisas saudáveis e aí acaba não sendo. Então você acha que isso não é bom para a nossa saúde? Acho que não. (B26)

Depende, pois se o alimento for modificado para uma alimentação melhor e para o bem da terra seria uma ideia. (E10)

Sim, pois acaba com os danos causados por insetos-praga. (A10) 
Com certeza, pois não apresenta danos à saúde, sem falar que ele atende ao consumidor com mais eficiência. (D3)

\section{$\underline{\text { Ceticismo moral }}$}

Talvez sim, pois não vejo problemas, além do caso do salmão escapar para o ambiente e poder acabar com a espécie natural, mas de resto não vejo malefícios, tanto na saúde quanto na economia. (B3)

Sim, apesar de beneficiar mais o comércio pelo crescimento acelerado o preço aumenta, não sei se influencia na questão da qualidade do produto, mas consumiria da mesma forma. (B17)

Não, pois não tenho interesse. (C25)

\section{H - Princípio moral}

A seguir, serão apresentados os resultados obtidos para as variáveis referentes aos princípios morais, efeitos benéficos, precaução, responsabilidade social e saúde, autonomia da vontade e respeito e consideração pelos animais por instrumento considerado na análise.

No gráfico 12 são apresentados os dados referentes a distribuição das frequências de princípios morais emergentes nos discursos dos estudantes sobre os alimentos transgênicos.

Gráfico 12 - Painel de gráficos relacionados a distribuição da frequência dos princípios morais dos estudantes por instrumento analisado
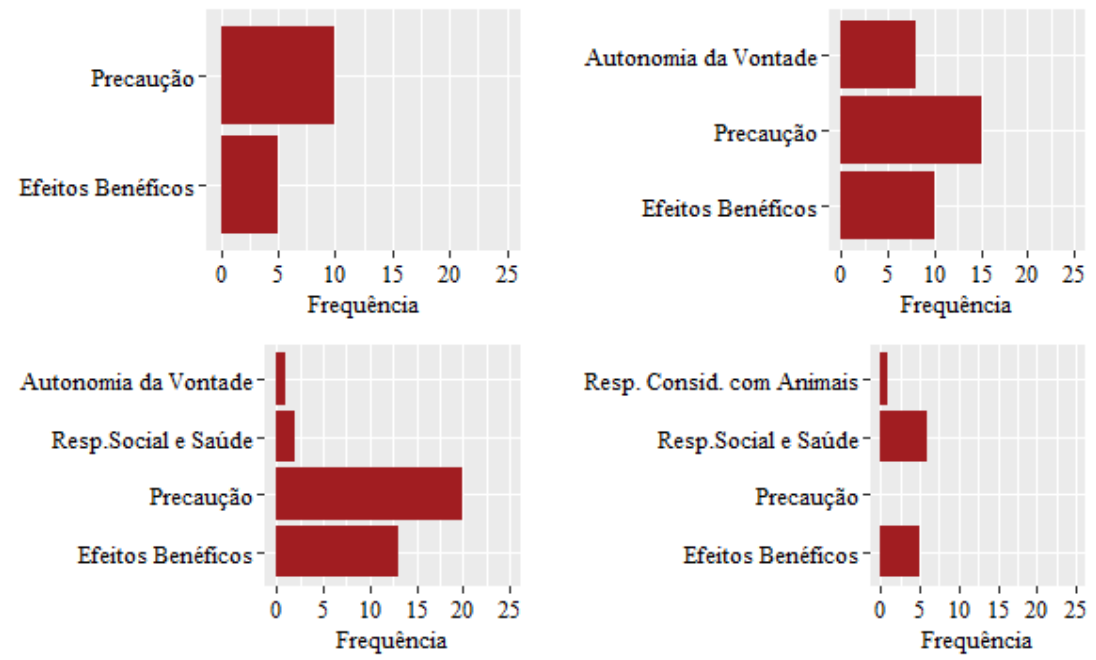

Fonte: elaboração da autora.

$\mathrm{Na}$ entrevista cinco $(33,3 \%)$ apresentaram como princípio os efeitos benéficos, 10 $(66,7 \%)$ expressaram como princípio a precaução e não houve considerações sobre os princípios autonomia da vontade e respeito, responsabilidade social e saúde e consideração pelos animais. No questionário, $10(30,3 \%)$ expressaram efeitos benéficos, 15 (45,5\%) 
apresentaram precaução, não houve considerações sobre responsabilidade social e saúde e sobre respeito e consideração pelos animais e oito $(24,2 \%)$ expressaram o princípio autonomia da vontade.

Na QSC milho transgênico $13(36,1 \%)$ expressaram efeitos benéficos, $20(55,6 \%)$ apresentaram precaução, dois $(5,6 \%)$ apresentaram responsabilidade social e saúde, um $(2,8 \%)$ manifestou autonomia da vontade e não houve nenhuma consideração acerca de respeito e consideração pelos animais. Na QSC salmão transgênico cinco $(12,8 \%)$ expressaram efeitos benéficos, $27(69,2 \%)$ expressaram precaução, seis $(15,4 \%)$ apresentaram responsabilidade social e saúde, não houve nenhuma consideração sobre autonomia da vontade e apenas uma $(2,6 \%)$ em relação a respeito e consideração pelos animais.

Os gráficos do painel acima dizem respeito aos instrumentos entrevista, QSC milho e salmão transgênico, partindo da primeira linha, da esquerda para a direita. Ao analisar a tabela e o gráfico acima, percebeu-se que os princípios morais efeitos benéficos e precaução são as variáveis que possuem a maior frequência entre as demais. Para a categoria respeito e consideração com os animais obteve-se apenas uma observação na QSC salmão transgênico e na categoria respeito social e saúde foram obtidas oito observações no total dos instrumentos analisados.

Também, foram analisados os princípios morais: efeitos nocivos, proteção do meio ambiente, naturalismo conservadorista, proteção das gerações futuras, conformismo moral e racionalismo instrumental (Gráfico 13)

Gráfico 13 - Painel de gráficos em relação a distribuição da frequência dos princípios morais dos estudantes por instrumento analisado
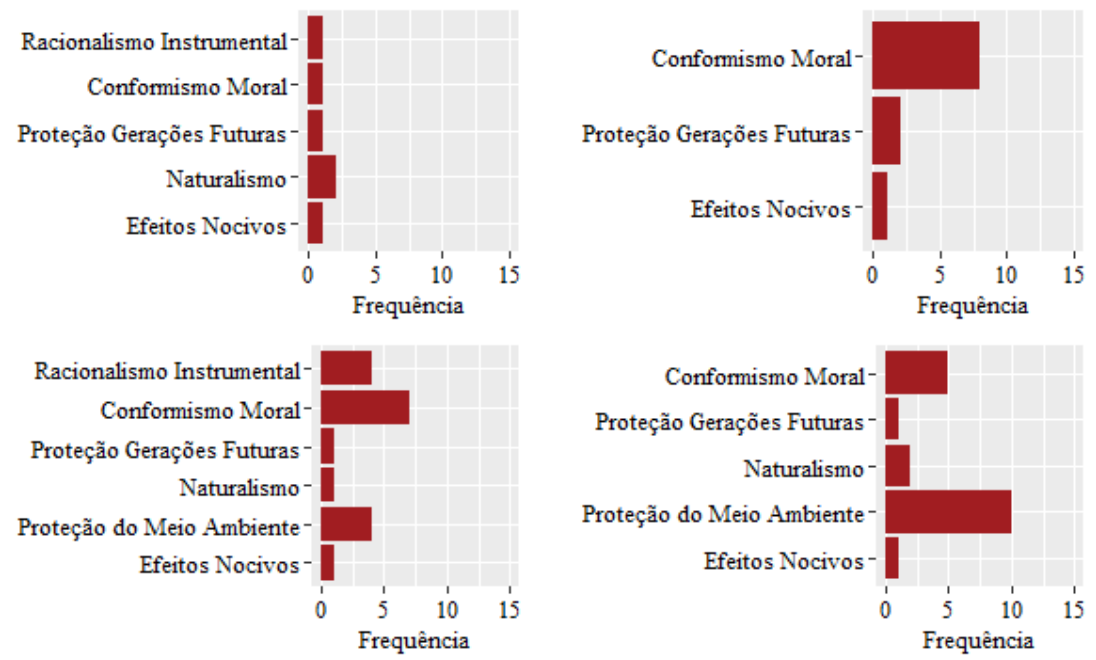

Fonte: elaboração da autora. 
$\mathrm{Na}$ entrevista um $(14,3 \%)$ apresentou o princípio efeitos nocivos, três $(42,9 \%)$ apresentaram o princípio naturalismo conservadorista, nenhum estudante expressou o princípio proteção ao meio ambiente, um (14,3\%) expressou proteção das gerações futuras, um $(14,3 \%)$ apresentou conformismo moral e um $(14,3 \%)$ apresentou o princípio racionalismo instrumental. No questionário um $(9,1 \%)$ expressou efeitos nocivos, dois $(18,2 \%)$ apresentaram proteção das gerações futuras, oito $(72,7 \%)$ expressaram conformismo moral e não houve considerações nos sobre os princípios proteção do meio ambiente, naturalismo conservadorista, e racionalis mo instrumental.

Na QSC milho um $(5,3 \%)$ expressou efeitos nocivos, quatro $(21,1 \%)$ expressaram proteção do meio ambiente, oito $(42,1 \%)$ apresentaram conformismo moral, quatro $(21,1 \%)$ expressaram racionalismo instrumental, um $(5,3 \%)$ apresentou naturalismo conservadorista e um $(5,3 \%)$ expressou proteção das gerações futuras. Na QSC salmão transgênico um $(5,3 \%)$ apresentou o princípio efeitos nocivos, $10(52,6 \%)$ expressaram o princípio proteção do meio ambiente, dois $(10,5 \%)$ apresentaram naturalismo conservadorista, cinco $(26,3 \%)$ expressaram conformismo moral, um $(5,3 \%)$ apresentou proteção das gerações futuras e não houve nenhuma consideração para racionalis mo instrumental.

Os gráficos do painel acima fazem referência aos instrumentos entrevista, questionário, QSC milho transgênico e QSC salmão transgênico, partindo da primeira linha, da esquerda para a direita. Na entrevista o princípio com maior ocorrência foi o naturalismo conservadorista, no questionário foi o conformismo moral, na QSC milho transgênico os três princípios de maior ocorrência foram: conformismo moral, racionalismo instrumental e proteção do meio ambiente, respectivamente. Na QSC salmão os dois princípios de maior ocorrência foram proteção do meio ambiente e conformismo moral.

A partir da identificação dos princípios morais nos discursos dos estudantes foi possível perceber que após a realização da SD os estudantes passaram a considerar em suas falas princípios não apresentados nos instrumentos utilizados previamente, como por exemplo, considerações sobre o meio ambiente e os animais nos princípios proteção do meio ambiente e respeito e consideração pelos animais. O conformismo moral apareceu em todos os instrumentos.

A seguir serão apresentados exemplos dos discursos referentes aos princípios emergentes. 
$\underline{\text { Autonomia da vontade (autodeterminação) }}$

Concordo, por que o milho Bt possui um gene uma bactéria que produz uma toxina com ação intestinal, e não faz mal a minha saúde. (D16)

Sim, por que eu gosto. (C16)

Sim, já utilizo alimentos transgênicos. (E25)

\section{Conformismo moral}

Sim, já utilizo, por ter grande quantidade nos mercados, e falta de opção natural. (C18)

Eu nem concordo, nem discordo, pois todos sabemos que ele está presente na nossa alimentação e não achamos ruim e até agora ele não tem prejudicado, pois ainda são desconhecidos seus efeitos todos e não se sabe o que ele pode causar futuramente e, por isso, muitas pessoas ainda tem o pé atrás. (A7)

Sim, por que os riscos que pode causar muitos alimentos que nós comemos e também tem as mesmas qualidades nutricionais que o salmão comum. (E25)

\section{$\underline{\text { Efeitos benéficos }}$}

Concordo ele pode se tornar um grande aliado no futuro para a agricultura e para uma melhor produção desse milho, os alimentos transgênicos vieram para o benefício da população. (C11)

Com certeza, pois não apresenta danos à saúde, sem falar que ele atende ao consumidor com mais eficiência. (D13)

\section{$\underline{\text { Efeitos nocivos }}$}

Discordo em parte, pois até o momento, estudos não apontam riscos para a saúde, porém por ser um alimento geneticamente modificado, ele acaba perdendo as suas características originais de sabor e sua naturalidade, então, pode ser que faça falta de alguma forma no nosso organismo. (B3)

Não compraria, pois perde os nutrientes. (D18)

\section{$\underline{\text { Naturalismo conservadorista }}$}

ENT.: Perfeito. E o que você entende por transgênicos? B19: É tipo coisa que é geneticamente modificada. ENT.: Ok. Você é contra ou a favor a isso? B19: Contra também. ENT.: Ok. É, me explica por quê que você é contra. B19: A mesma forma da clonagem, tipo, tira a forma natural do que já foi criado. (B19)

Discordo, por que tem que ser os alimentos da natureza. Com isso ele pode diminuir os danos causados por insetos-praga, mas também perder algumas coisas que fazem melhor ao nosso corpo. (C20) 


\section{$\underline{\text { Precaução }}$}

ENT.: Transgênicos? B14: Transgênicos, ah, dos alimentos né? ENT.: Isso. B14: Que são geneticamente modificados. ENT.: Isso, são modificados geneticame nte. Você é a favor ou contra? B14: Contra. ENT.: Por quê? B14: Ah, como eu já tinha falado, é que muitas vezes a galera não sabe como, o que pode acontecer futuro com a gente. Então pode trazer um câncer esses alimentos, então não. (B14)

Não. Por que não sei se isso iria me fazer bem ou me causar uma doença no futuro. (A25)

\section{Proteção do meio ambiente e da biodiversidade}

Não concordo. Entendo que ao longo do tempo a burrice humana em relação a falta de planejamento fez a população de humanos crescer demasiadamente e alterações na estrutura genética de alguns organismos tiveram que ser feitas para melhorar o rendimento etc. Mas, em minha opinião o ser humano não deveria tentar modificar processos naturais, pois os mesmos possuem seu equilibrio natural, qualquer alteração num indivíduo afeta toda a cadeia, pois a natureza é interdependente. Não se deve tentar alterar um sistema com bilhões de anos pela irresponsabilidade humana, mas fazer o quê?! (C18)

Não compraria, por que esse tipo de mudança afetaria duas coisas muito importantes: a saúde e o meio ambiente. É ruim você pensar somente em benefícios e virar as costas para esses dois fatores. (B19)

\section{$\underline{\text { Proteção das gerações futuras }}$}

Não, por que poderia causar futuramente um problema. (B22)

Não tenho uma opinião formada, mas acho que seria um pouco difícil retirar o milho do mercado, e depois de tanto tempo, o preço seria bem alto. Também tem a questão da produção ser bem maior. Depende de várias coisas diferentes, também tem suas partes ruins, não podemos saber o que irá acontecer no futuro. (A1)

\section{$\underline{\text { Respeito e consideração com os animais }}$}

Não, acho que o que eles fazem com o salmão é crueldade, pois eles não podem viver livremente, se reproduzir, só são feitos para crescer. (D5)

$\underline{\text { Responsabilidade social e saúde }}$

Eu discordo, pois, o milho Bt apresenta vantagens no aumento da produção, financeiramente, no impacto ambiental. Porém o número de pragas irá aumentar e o mais importante os riscos à saúde, os estudos não são conclusivos sobre a saúde, 
mais provavelmente deve ter. E o mais importante para mim, primeiro é a saúde apesar de uma economia também é importante. (B7)

e virar as costas para esses dois fatores. (B19)

Depende, se isso não prejudicar a minha saúde e a saúde dos demais. (D9)

Foram realizados testes para analisar a influência da oficina nas percepções dos estudantes em relação ao uso de transgênicos. Essas considerações foram separadas em morais e não morais.

Com a aplicação dos testes, percebeu-se se o módulo sobre transgênicos da oficina estimulou os estudantes a fazerem considerações do domínio moral ao invés de não terem feito alguma consideração ou terem feito considerações não morais. Assim, foi realizado o teste de McNemar, sob as seguintes hipóteses:

$\mathrm{H}_{0}$ : A oficina não mudou as considerações do domínio moral dos estudantes.

$\mathrm{H}_{1}$ : A oficina mudou as considerações do domínio moral dos estudantes.

Após a aplicação do teste para as quatro situações, entrevista $\mathrm{x}$ milho, entrevista $\mathrm{x}$ salmão, utilização x milho e utilização x salmão, obteve-se p-valor igual a 1 para todos os testes, ou seja, maiores que o nível de significância pré-estabelecido de 5\%. Portanto, a hipótese nula de que a oficina não mudou as considerações do domínio moral dos estudantes.

$\mathrm{Na}$ SD referente aos transgênicos para estudantes do $2^{\circ}$ ano do EM foi analisado se a parte da oficina referente ao tema em questão alterou ou não a percepção dos estudantes, em relação a consciência ecológica e considerações do domínio moral para os alimentos transgênicos. Assim, aplicando o teste de McNemar, pode-se concluir que:

- Análise de transgênicos: em somente um caso houve p-valor menor que o nível de significância determinado anteriormente. No teste uso utilização x uso salmão, rejeitou-se a hipótese nula, ou seja, houve evidências para afirmar que a opinião dos estudantes em relação ao uso foi modificada com base na questão sobre utilização e salmão transgênico;

- Consciência ecológica: para todos os quatro testes realizados, entrevista x milho, entrevista x salmão, utilização x milho e utilização x salmão, obteve-se p-valor para a rejeição a hipótese nula, ou seja, conclui-se que a oficina mudou a consciência ecológica dos estudantes em todos os casos; e

- Considerações relativas ao domínio moral: para todos os quatro testes realizados, entrevista x milho, entrevista x salmão, utilização x milho e utilização x salmão, obteve-se p-valor para não se rejeitar a hipótese nula, ou seja, conclui-se que a oficina não mudou as considerações do domínio moral dos estudantes. 


\subsubsection{QSC sobre clonagem}

A seguir será apresentada a análise descritiva dos dados coletados antes e depois da realização da SD sobre clonagem terapêutica e reprodutiva.

\section{A - Conhecimento prévio sobre a biotecnologia}

O gráfico 14 apresenta os dados relativos a distribuição da frequência de estudantes que apresentaram conhecimento prévio sobre clonagem.

Gráfico 14 - Distribuição da frequência de estudantes que apresentaram conhecimento prévio sobre clonagem

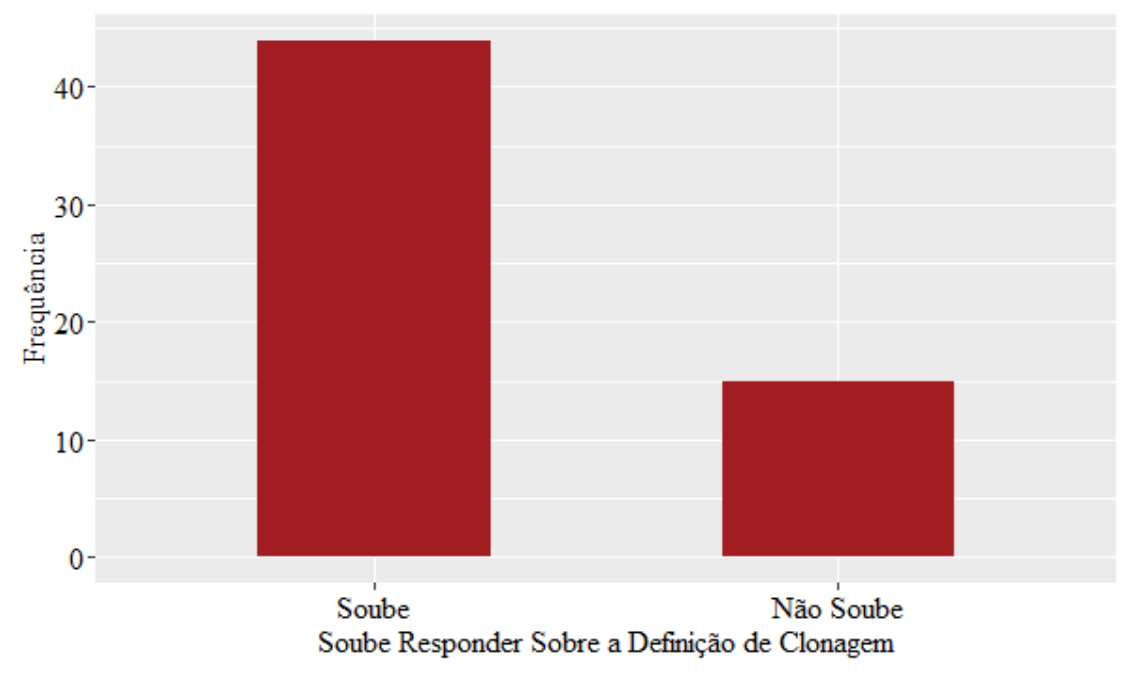

Fonte: elaboração da autora.

Quando perguntados se sabiam ou não o que era clonagem reprodutiva dos 62 entrevistados, 44 souberam responder o que é clonagem reprodutiva, o que corresponde a $71 \%$ do total. Outros $15(24 \%)$ dos estudantes não souberam responder e três (5\%) dos estudantes não responderam.

Inicialmente, a maioria dos estudantes souberam responder o que é clonagem. Muitos dos estudantes associaram a clonagem reprodutiva a práticas ilícitas como clonagem de carros, CDs, DVDs e documentos, o que os levava a ter uma certa noção de que clonagem seria fazer uma cópia idêntica de algum objeto ou pessoa geneticamente idêntica. Acredita-se que muitos conseguiram responder a essa questão devido à presença na mídia de filmes "A ilha" e até de uma novela brasileira intitulada "O clone" que abordavam o referido tema. 
A seguir apresentamos alguns exemplos de discurso de estudantes que tinham conhecimento prévio.

Conhecimento prévio

ENT.: Você sabe alguma coisa sobre clonagem? A1: Eu sei que teve a da vaca e a da ovelha Dolly. ENT.: Ok. A da ovelha Dolly foi bem falada né. E você sabe o quê que é a Clonagem? A1: Eu já fiz um trabalho há muito tempo atrás, acho que foi na quinta série sobre a clonagem da ovelha Dolly e da vaquinha Vitória. Só que eu não lembro muito bem, porque eu acho que os dois são bem diferentes. ENT.: São. Agora sem entrar no detalhamento da, da técnica, de como faz. O quê que é clonar? A1: Pegar as características genéticas de um e reproduzir no outro. (A1)

ENT.: Perfeito, joia. $\mathrm{Eu}$ vou te fazer umas perguntas relacionadas com conhecimento de biologia, certo? Se você souber, melhor, se não souber, tranquilo, não tem problema nenhum. O que você entende por clonagem? C15: Ao meu ver seria você pegar algum material genético de algum ser, reproduzir aquele material genético no outro local, pra tá criando a mesma coisa de onde você tirou o material genético. ENT.: Ok. Você é contra ou a favor a isso? C15: Depende da situação. C15: Ok, pode me dizer uma situação que você seria favorável, sem problema nenhum? C15: Uma situação que eu seria favorável, é a favor de animal, clonar animal. (C15)

$\underline{\text { Sem conhecimento prévio }}$

ENT.: Já ouviu falar de Clonagem? C27: Na Novela. ENT.: Tudo bem. É mais ou menos aquilo mesmo. Você é a favor ou a contra a clonagem? C27: Não seria a favor. Porque clonar um indivíduo é meio paia, iam ter dois iguais melhor ser cada um do seu jeito. E de animais você concorda? Concordo. Por que? Porque os animaizinhos são os animaizinhos, né. (C27)

ENT.: Perfeito. É, eu vou fazer algumas perguntas relacionadas a conhecimentos relativos à Biotecnologia. O que você entende por clonagem? D13: Clonagem? ENT.: Isso. D13: Nada. (D13)

\section{B - Opiniões contrárias ou favoráveis à aplicação da biotecnologia}

Nesse item procederemos a análise da percepção dos estudantes quanto a serem contrários ou favoráveis a clonagem reprodutiva. O gráfico 15, na próxima página, apresenta os dados referentes a percepção dos estudantes sobre a clonagem na entrevista e na QSC.

Ao analisar a percepção dos estudantes sobre clonagem reprodutiva na entrevista podese perceber que a quantidade de estudantes contrários e favoráveis foi quase a mesma, 17 e 16 entrevistados, $27,42 \%$ e $25,81 \%$, respectivamente. Outros 12 estudantes $(19,35 \%)$ se mostraram a favor em animais, enquanto $14(22,58 \%)$ dos estudantes não tinham argumentos suficie ntes para serem categorizados. Apenas três estudantes (4,84\%) deixaram em branco ou não opinaram. 
Na QSC sobre clonagem reprodutiva 21 estudantes se mostraram contrários à clonagem reprodutiva, o que corresponde a $33,87 \%$ do total e $35(56,45 \%)$ foram favoráveis. A quantidade de estudantes com argumentos insuficientes e em branco/não opinou foi a mesma, três estudantes, o que corresponde a 4,84\% para cada uma dessas categorias.

Quando questionados na entrevista se seriam a favor da clonagem em animais, 12 $(19,35 \%)$ dos estudantes revelaram ser a favor a clonagem.

Gráfico 15 - Distribuição da frequência de estudantes contrários ou favoráveis a clonagem

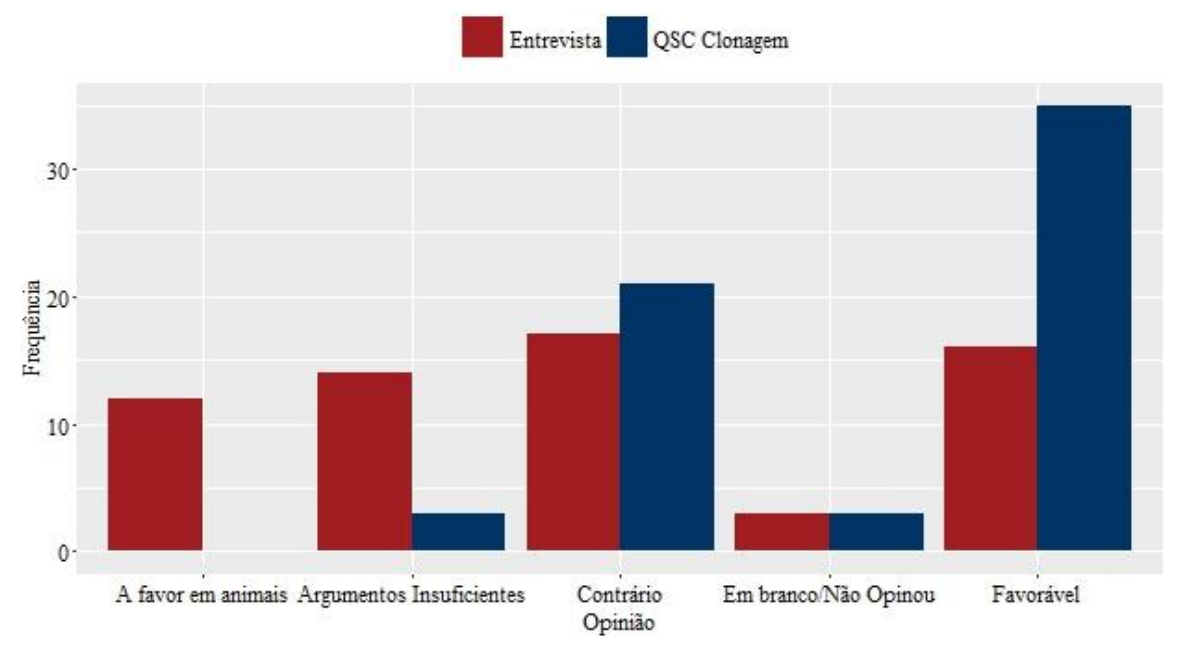

Fonte: elaboração da autora.

Então, observou-se que houve um aumento no número de estudantes que responderam a QSC, em relação a entrevista. Esse dado sugere que a SD (módulo clonagem) melhorou a participação dos estudantes. Percebeu-se que na QSC clonagem a frequência de estudantes favoráveis aumentou em relação a entrevista. Assim, quando se trata de uma aplicação da biotecnologia relacionada a sobrevivência e saúde os estudantes tendem a considerá-la moralmente aceitável e legitima, uma vez que, essas estão relacionadas a uma melhoria na qualidade de vida de indivíduos e populações humanas. Esse fato, também pode estar associado a considerações afetivas dos participantes, já que a QSC em questão tratava de salvar a vida de uma criança com leucemia.

Como dito anteriormente, as QSC são contexto dependentes, ou seja, as variações nos contextos em que as questões estão envolvidas provocam modificações nas considerações dos estudantes. Além do contexto, também temos que considerar a influência de crenças e valores pessoais na análise de cada questão. 
Nessa QSC, também identificamos discursos polarizados preocupados com: a) as contribuições que a clonagem reprodutiva pode trazer para salvar a vida de uma criança; e b) crenças e valores pessoais que representaram uma reação negativa diante da possibilidade de interferência na vida de um ser humano.

A seguir apresentamos exemplos dos discursos contrários e favoráveis à clonagem reprodutiva.

\section{$\underline{\text { Contrário }}$}

Não optar pela clonagem, pois a segunda criança seria a dependência da outra viver, para mim clonagem não é algo natural, pois a criança nasce sem mesmo ter opção de sua escolha, ao final as duas acabariam sofrendo. (B17)

Não. Pois não é certo criar um ser humano por uma causa que ele não tem direito de responder. (B24)

\section{Favorável}

Aceitar a questão do clone humano para salvar a criança. (B26)

$\mathrm{Na}$ minha opinião eles deveriam fazer o clone, pois os pais não medem esforços pela vida de seus filhos. (C4)

Alguns estudantes se manifestaram contrários a clonagem em humanos, mas a favor em animais. Nesses casos, percebeu-se que os estudantes não conferiram status moral aos animais. Outros, por sua vez, se manifestaram contra a clonagem em humanos e animais, conferindo status moral aos animais por serem "parecidos" com os seres humanos. Geralmente, os estudantes favoráveis a clonagem em humanos, também são favoráveis em animais, entretanto um estudante apresentou uma variação, ele foi a favor em humanos e contrário em animais.

Em um estudo de Dawson e Schibeci (2003) estudantes foram questionados sobre as suas atitudes em relação a vários processos biotecnológicos que envolviam o uso de microrganismos, plantas, animais e seres humanos. A maioria dos estudantes (>90\%) aprovou o uso de microrganismos em processos biotecnológicos específicos, como a produção de cerveja. Os estudantes apoiaram menos a modificação genética de plantas (71\% - 82\%), e menos ainda a modificação genética em animais $(34 \%$ - 39\%) e em seres humanos $(41 \%$ - 45\%). Os resultados apontaram que os estudantes têm uma atitude mais positiva em relação à modificação genética de microrganismos e plantas, do que a modificação genética de culturas alimentares, animais e seres humanos. 
Seguem os exemplos de discursos para exemplificar as categorias: favoráveis em animais, contrário em humanos e animais, a favor em animais e contrário em humanos.

$\underline{\text { Favoráveis em animais e contrários em humanos }}$

ENT.: Você concorda com isso? A26: Não. ENT.: Por quê? A26: Eu acho errado. Tipo, eu nunca ouvi falar sobre nada, mas eu acho errado por que... não sei, é... uma pessoa vai e clona a outra, isso já aconteceu? Já né? Ou não? ENT.: Teve uma vez que um grupo de pesquisa disse que conseguiu clonar um ser humano. A26: Então, só vai clonar outra, é errado... ENT.: Do ponto de vista assim, se for um animal, você concordaria? A26: A sim. Um animal, acho que sim. ENT.: Aham. É, por quê que cê acha que com ser humano não? É uma opinião sua, é uma coisa sua. Às vezes é alguma coisa da religião que... A26: Não sei exatamente. Mas eu acho errado porque, ah, eu não sei, não sei explicar. (A26)

ENT.: Você seria a favor ou contra essa manipulação genética, essa manipulação do material genético pra fazer clones de animais? B10: Olha, pra mim tudo bem. Assim, eu acho que animal, animais numa boa, agora, seres humanos eu já não acho muito legal não. ENT.: Aham. Por quê? Gustavo: A, não sei, eu acho que a gente foi criado pra ser, não sei. Nós somos únicos, então, acho que a gente não foi feito pra ser duplicado. Cada um tem a sua maneira de interagir com a sociedade, com o mundo, eu acho que duplicar, não sei, eu não concordo com isso. Agora, animais eu sou super a favor. (B10)

\section{Contrário em humanos e animais}

ENT.: Você seria contra ou a favor à clonagem? E28: Eu acho que eu seria contra dependendo do que fosse. E a favor se fosse para o bem. ENT.: Ok. Você é contra, por exemplo, animais, pessoas? E28: Acho que pessoas também né, não sei explicar. Porque às vezes é "sou contra em pessoas e em animais. (E28)

\section{Favorável em humanos e contrário em animais}

[...] E12: Uai, depende da, depende de cada um, se ele quiser ser clonado. ENT.: No caso do ser humano né? E no caso do animal? E12: Não, no caso do animal não, porque ele não tem como expressar o que tá sentindo. ENT.: Isso. Aí você acha que ele seria... E12: Eu seria contra. ENT.: Ok. Porquê que cê seria contra? E12: Porque o animal ele não fala, tipo, ele não tem como falar o quê que ele tá sentindo, se pode ou não fazer aquilo. E12: Não, mas também o, ele vai lá tá sofrendo a toa, porque não sabe se vai dar certo. Não sabe porquê que ele vai tá sentindo aquela... e ele vai morrer à toa, porque pra testar você tem que ter uma cobaia, ai a cobaia vai e morre à toa se acontecer alguma coisa. (E12) 


\section{$\underline{\text { Favorável em humanos e animais }}$}

[...] B1: Depende, porque embora eu seja católico eu não acredito que seja brincar de Deus eu acho que a clonagem pode servir para a pesquisa de muitas coisas importantes, por exemplo, nós podemos entender mais sobre organismos...acho que com a clonagem a gente poderia entender mais sobre o nosso próprio organismo. Como eu não sou realmente formado. ENT.: Então você é a favor da clonagem? Dependendo para o que seja, se for assim para o bem da ciência ou da humanidade eu acredito que seja bem interessante. (B1)

ENT.: Você seria, se fosse possível clonar uma pessoa, um animal, você seria a favor? Ou contra? C1: Sim, a favor. ENT.: A qualquer tipo de clonagem? Até de um ser humano? C1: Sim, a favor. ENT.: Por que você é a favor? C1: Porque tipo, animais estão em extinção, então se a gente clonasse aqueles que estão em extinção teria mais. ENT.: Sim, e o ser humano por exemplo? C1: O ser humano dependendo se a pessoa quiser, depende se ela quiser. (C1)

\section{C - Domínio moral}

A seguir, o gráfico 16 apresenta os resultados da ocorrência de discursos do domínio moral, não moral e argumentos insuficientes por parte dos estudantes.

Gráfico 16 - Distribuição da frequência de discursos do domínio moral e não moral, argumentos insuficientes e em branco/não opinou por instrumento

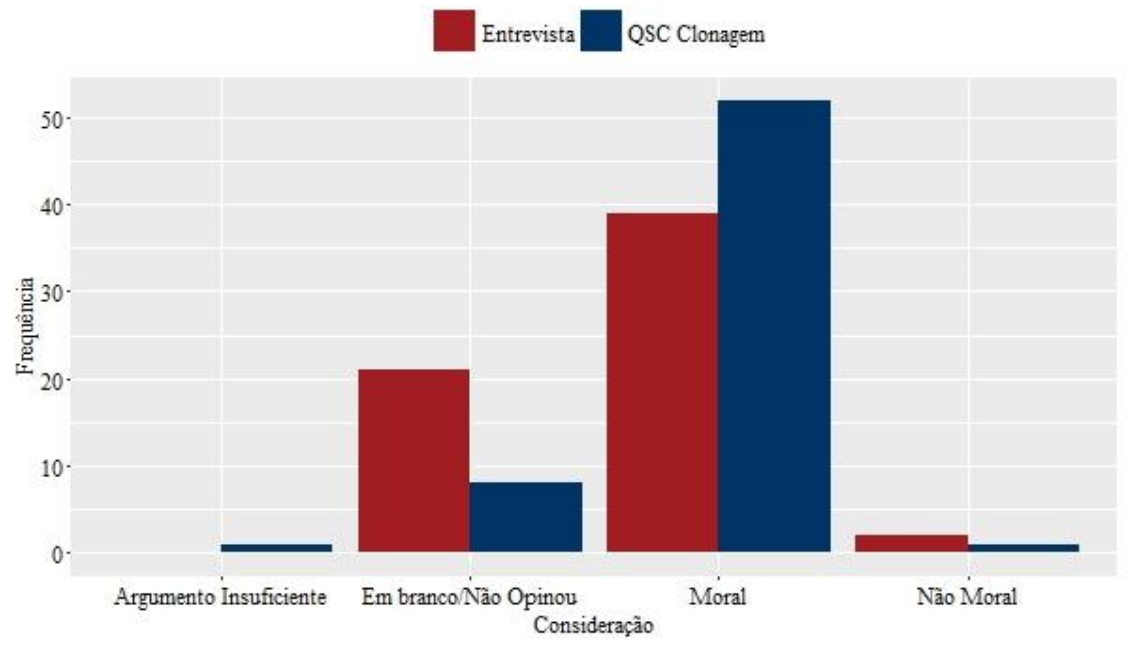

Fonte: elaboração da autora.

Ao analisar os discursos do domínio moral dos estudantes, percebeu-se que, tanto na entrevista quanto na QSC sobre clonagem reprodutiva, a maioria dos participantes apresentou respostas relacionadas ao domínio moral $(62,90 \%$ e $83,87 \%$, respectivamente). A categoria não moral teve apenas duas ocorrências na entrevista e, na QSC, uma. Ainda, um estudante não 
apresentou argumento suficiente para categorizar A categoria em branco/não opinou teve 21 ocorrências na entrevista e oito na QSC (33,87\% e 12,9\%), respectivamente.

A partir dos dados apresentados observou-se que na maioria dos casos os estudantes interpretam questões sobre clonagem com base em considerações relativas ao domínio moral, como observou-se nas outras questões. A seguir são apresentados alguns exemplos de discurso relativos ao domínio moral e não moral.

\section{$\underline{\text { Domínio moral }}$}

ENT.: Perfeito. E você é contra ou a favor à essa clonagem? A28: É, depende, se for pra benefício, é claro que eu sou a favor. Mas pra malefício eu não vou ser a favor, como, é, fazer essas clonagem, essas clonagem que os bandidos fazem né? Essas coisas ruins. Eu acho que não é benefício, mas assim, tem coisas dentro que dá benefício, então eu sou a favor. (A28)

Não deveriam fazer clonagem... Mesmo que seja um "ser humano", os pais não teriam o mesmo sentimento. (C31)

\section{Domínio não moral}

Na minha opinião, o casal deve pensar muito a respeito, por que são duas vidas em jogo. (E28)

ENT.: Então, você é contra ou a favor a esse tipo de técnica? De aplicação da biotecnologia? A10: Eu sou a favor. ENT.: Você acha importante a clonagem? Por que que você acha importante? A10: Novos conhecimentos. (A10)

\section{D - Julgamento moral}

Os discursos dos estudantes que responderam as questões com base em considerações morais, foram categorizados quanto ao tipo de julgamento moral. As categorias que emergiram foram: moral deontológica, moral utilitarista e argumento insuficiente para categorizar, quando não foi possível fazer a categorização do discurso.

No gráfico 17, na próxima página, estão relacionados os percentuais por categoria utilizada no julgamento moral dos estudantes.

$\mathrm{Na}$ entrevista, 23 dos 39 entrevistados (58,97\%) apresentaram uma moral deontológica, 13 dos 39 (33,33\%) uma moral utilitarista e apenas 3 dos 39 (7,69\%) entrevistados apresentaram argumentos insuficientes para categorizar. No caso da QSC sobre clonagem reprodutiva 25 dos $52(48,08 \%)$ respondentes apresentaram uma moral deontológica, 23 dos $52(44,23 \%)$ uma moral utilitarista e quatro (7,69\%) apresentaram argumentos 
insuficientes para categorizar. Assim, percebeu-se que a categoria moral deontológica teve um maior percentual de ocorrência tanto na entrevista quanto na QSC.

Gráfico 17 - Distribuição da frequência de estudantes por categoria de julgamento moral, deontológica, utilitarista, ceticismo moral e argumentos insuficientes

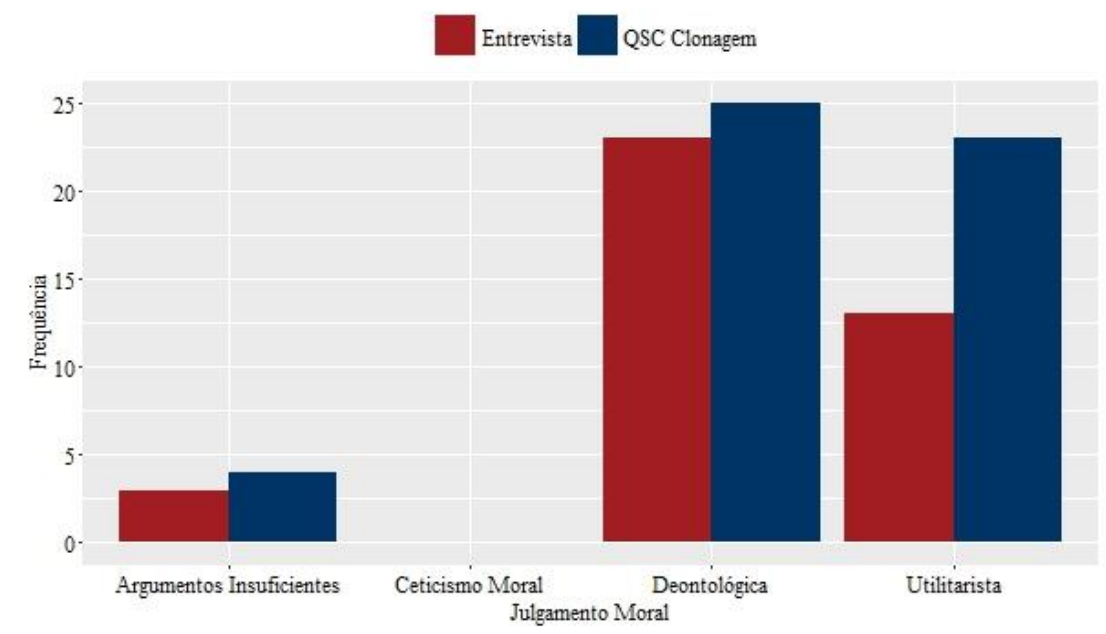

Fonte: elaboração da autora.

Esses resultados mostraram que as normas/regras evocadas na moral deontológica desempenham um papel importante na tomada de decisões quando se trata de uma aplicação da biotecnologia voltada a intervenções sobre a vida/sobrevivência e a saúde das pessoas envolvidas.

Os julgamentos morais representam um contexto útil de investigação sobre o conflito entre as estratégias baseadas em regras (moral deontológica) e decisões de caráter consequencialista (moral utilitarista), isso, por que as escolhas morais são, por vezes, influenciadas por valores protegidos e sagrados.

No caso dos transgênicos, o percentual de participantes que julgaram essas aplicações utilizando a moral utilitarista, ou seja, com base nas suas consequências foi maior do que os que julgaram utilizando a moral deontológica. Já em relação a clonagem reprodutiva houve uma inversão desse resultado, o que nos sugeriu que estejamos lidando com um possível quadro de valores protegidos e/ou sagrados, onde o julgamento moral se apoia nas regras (moral deontológica), impedindo que o indivíduo faça uma análise da situação considerando os riscos e benefícios envolvidos.

Segundo Baron e Spranca (1997) o quadro de valores protegidos descreve uma escolha moralmente motivada por um conjunto absolutamente restritivo das regras. Valores protegidos 
estão isentos de trocas com outros valores; em teoria, eles não podem ser negociados ou violados por qualquer razão, não importa as consequências.

Bartels et al. (2014) afirmam que a ligação entre o não consequencialismo e valores protegidos pode não ser clara em um primeiro momento. Provavelmente, as pessoas se preocupam profundamente com as entidades sobre as quais têm um valor protegido, como por exemplo, família, espécies ameaçadas de extinção a ponto de motivar o não consequencialis mo, assim as pessoas apesar de se preocuparem com os resultados deixam de maximizar a bondade de resultados para essas entidades e parecerem ignorantes, na medida em que não fazem um balanço das consequências.

Os resultados de pesquisa sobre valores protegidos por meio da consideração da existência de uma flexibilidade moral sugerem que uma interpretação não consequencialista considera apenas uma parte da história, pois tomadores de decisão moral podem afirmar seus valores protegidos por julgarem uma ação específica como certa, mesmo em face de consequências indesejáveis. No entanto, as pessoas com valores protegidos, também são capazes de identificar situações em que os benefícios justifiquem compensações e a relação entre os valores protegidos e a avaliação das ações morais pode ser fortemente determinada por processos de atenção (BARTELS et al., 2014).

A literatura, também aponta a existência de valores sagrados. Segundo Bartels et al. (2014) bens como a vida humana, a saúde e a natureza, são tratados por pessoas em algumas comunidades como tendo intrínseco valor moral ou transcendental. Em algumas circunstâncias esses valores não devem ser trocados por valores seculares, especialmente bens que podem ser comprados ou vendidos. Por exemplo, vender um voto pode ser moralmente errado para muitas pessoas. O quadro de valores sagrados explica alguns casos de decisões não consequencialis tas, como o resultado da internalização de um conjunto de normas culturalmente definidas que limitam a maneira pela qual os diferentes tipos de produtos podem ser trocados por entre si. A maioria das pesquisas sobre os valores sagrados incide sobre regras e valores específicos da situação e engendram estratégias de decisão deontológica.

A seguir são apresentados exemplos de discursos relativos as categorias, moral deontológica e utilitarista.

$\underline{\text { Moral deontológica }}$

ENT.: Ok. Vou te fazer algumas perguntas específicas. O que você entende por clonagem? B21: A, sei lá, quando tipo, quando faz dois, dois seres da mesma, tipo, da mesma composição, alguma coisa assim. ENT.: Ok. Você é contra ou a favor à 
essa clonagem? B21: Contra. ENT.: Ok. Por quê? B21: A, num sei, tipo, tira a originalidade do ser ter dois da mesma forma. (B21)

ENT.: Então, é, você seria contra ou a favor desse tipo de técnica de Clonagem? D25: Eu seria contra. ENT.: Por quê? D25: Porque eu acho que não funciona assim, sabe? Num, num vai adiantar, e você ter um negócio mesmo original, ser você mesmo, entendeu? (D25)

\section{$\underline{\text { Moral utilitarista }}$}

Depende, porque embora eu seja católico eu não acredito que seja brincar de Deus eu acho que a clonagem pode servir para a pesquisa de muitas coisas importantes, por exemplo, nós podemos entender mais sobre organismos...acho que com a clonagem a gente poderia entender mais sobre o nosso próprio organismo. Como eu não sou realmente formado. Então você é a favor da clonagem? Dependendo para o que seja, se for assim para o bem da ciência ou da humanidade eu acredito que seja bem interessante. (B1)

Não usar o clone, pois não se sabe como a criança iria reagir a medula do clone, e também não e com toda certeza que o clone dará certo, se será compatível. (C1)

\section{E - Princípio moral}

Foram caracterizados os princípios morais que afloraram das percepções dos estudantes, de acordo com alguns princípios da Declaração Universal de Bioética e de Direitos Humanos (UNESCO, 2005), conforme gráfico 18, na próxima página.

Na entrevista as categorias efeitos benéficos e individualidade genética, representaram juntas $(55 \%)$ do total. Conformismo moral, moralidade religiosa e justiça tiveram apenas uma observação representando juntas $(7,5 \%)$ do total. Precaução, autonomia e responsabilidade individual e naturalismo conservadorista tiveram três observações cada, representando $(7,5 \%)$ e seis estudantes não tiveram argumentos suficientes para a categorização.

Na QSC a categoria individualidade genética, justiça e não discriminação e não estigmatização tiveram apenas uma observação, representando cada, 1,64\% do total. Precaução, naturalismo conservadorista e não identidade tiveram três observações representando juntas $(14,76 \%)$ do total. Moralidade religiosa e argumentos insuficientes tiveram quatro observações e representaram, separadamente $(6,56 \%)$ do total. A categoria valor da vida teve sete observações $(11,48 \%)$ e dignidade e direitos humanos teve oito observações $(13,11 \%)$. Conformismo moral não teve nenhuma observação e efeitos benéficos obteve a maior frequência com 24 observações $(39,34 \%)$ do total. 
Gráfico 18 - Distribuição da frequência de princípios morais apresentados pelos estudantes

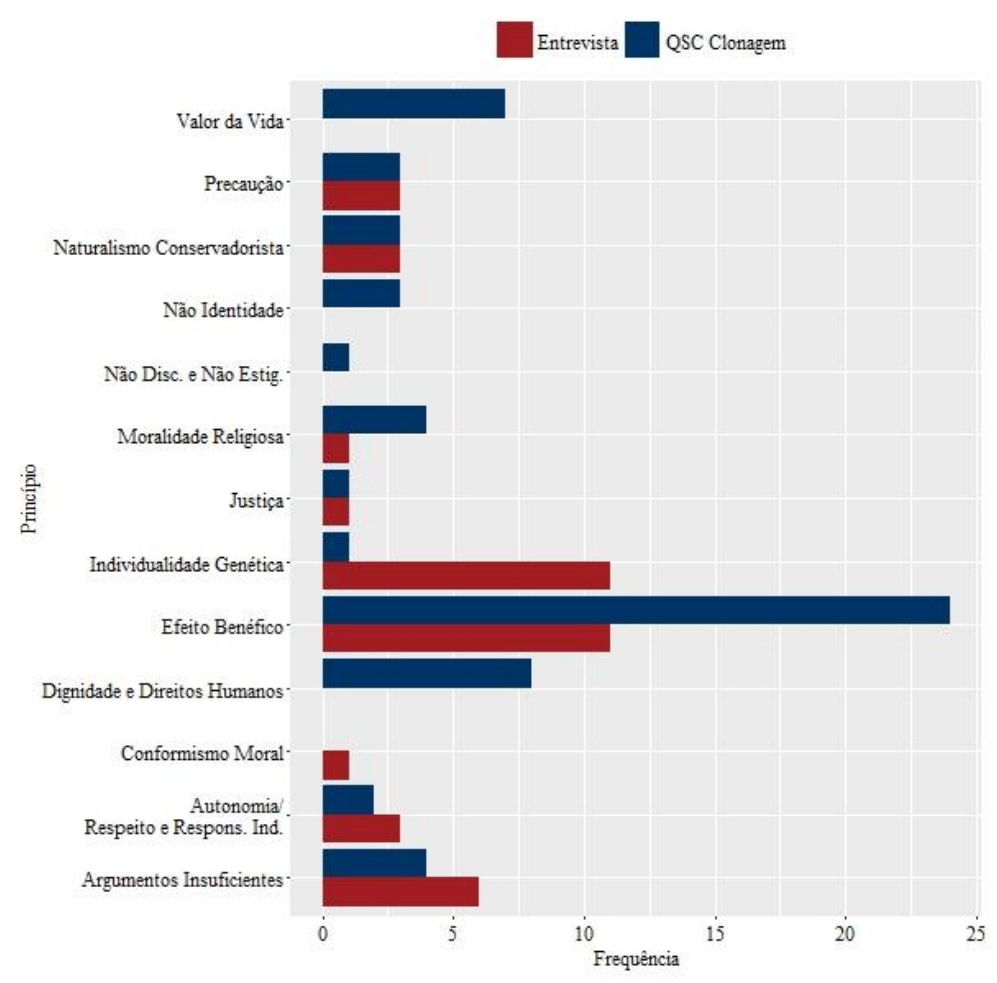

Fonte: elaboração da autora.

Essa categorização permitiu que mais de um princípio moral fosse observado nos discursos. Assim, os totais diferiram da quantidade de estudantes que apresentaram considerações morais.

A seguir são apresentados exemplos dos discursos de estudantes relativos aos princípios morais.

\section{Efeitos benéficos}

ENT.: Você é contra ou a favor a clonagem? E1: Eu sou a favor. ENT.: Por que você é a favor? Justamente por causa disso? E1: Porque ele veio para o bem, não foi criado uma coisa para o mal, tipo, pode ser que durante a execução haja divergência mas o intuito final não é em erro, um mal para a humanidade. Apesar de eu não gostar muito da humanidade. (E1)

\section{$\underline{\text { Individualidade genética }}$}

ENT.: Perfeito. Vou fazer umas quatro perguntas relacionadas a conceitos de Biotecnologia e Biologia e correlatos. O que você entende por clonagem? C31: Clonagem, clonagem eu acho que seja, sei lá, criar uma, uma, um ser igual a outro. ENT.: Você é contra ou a favor a essa clonagem? C31: Sei lá, contra e a favor, 
porque de um jeito é bom, de outro jeito é meio doentio, ter uma pessoa igual a você é um negócio meio assim. (C31)

\section{$\underline{\text { Precaução }}$}

Não usar o clone, pois não se sabe como a criança iria reagir a medula do clone, e também não e com toda certeza que o clone dará certo, se será compatível. (C1)

\section{Autonomia e responsabilidade individual}

ENT.: Isso. É possível fazer isso em animais. Você concorda com a clonagem? E2: Depende. Acho que em plantas e em animais é uma coisa que não vai ter um problema. Em seres humanos não, porque se a pessoa quiser ser clonada é outra coisa, tem que depender do que ela quer, se ela não quiser eu acho que é errado. ENT.: Mesmo ela querendo você acha que... E2: Vai trazer um problema, até porque a pessoa pensa que vai ser totalmente igual a ela, mas o modo de pensar vai ser totalmente diferente. (E2)

\section{Naturalismo conservadorista}

Não fazer isso, deixar a filha morrer de uma forma natural. (B25)

\section{Conformismo moral}

ENT.: Perfeito, então eu vou te fazer algumas perguntas. O que você entende por clonagem? C19: Clonagem é assim, um ser igual a outro né. Pega um gênero do ser e faz o mesmo. ENT.: Você é contra ou a favor a isso? C19: Eu sou a favor. ENT.: Ok. Me explica pra mim porque você é a favor. C19: Uai, porque não tem nada de mal, você vai clonar um ser, não vai dar nada, só vai ser clonado. (C19)

\section{$\underline{\text { Moralidade religiosa }}$}

Sou contra qualquer tipo de clonagem humana, mas respeito totalmente a opinião de outras pessoas. Tenho princípios onde a vida é sagrada, uma benção, que só pode ser concedida através de Deus. (B10)

\section{$\underline{\text { Justiça }}$}

ENT.: Ok. Vou te fazer quatro perguntas, ok? Na realidade são seis. O que você entende por clonagem? D18: Que multiplica as células de outra pessoa. ENT.: Ok. Você é contra ou a favor a isso? D18: Contra. ENT.: Ok. Me explica por que que 
você acha que é contra. Me explica então porque que você é contra a clonagem. D18: Porque eu não acho certo, não acho justo com a pessoa ser clonado. (D18)

$\underline{\text { Dignidade e direitos humanos }}$

Muito errado fazer um clone por causa do filho doente o clone seria muito "descartável" ou seria uma vida normal e não era a mesma coisa olhar para ele. (C5)

$\underline{\text { Valor da vida }}$

Aceitar a questão do clone humano para salvar a criança. (B26)

$\underline{\text { Não discriminação e não estigmatização }}$

Para salvar a vida da filha doente eu apoio que o casal opte pela clonagem, visto que estejam cientes de dar todo carinho e cuidado para essa nova criança, que será normal e não deverá ser vista como experimento científico e vem ser vulgarmente chamada de clone. (B21)

$\underline{\text { Não identidade }}$

Na minha opinião com essa clonagem até o processo todo ela talvez já estaria morta, e também não é justo criar alguém que viva como um remédio humano. Já pensaram na dor que ela sentirá, os pais poderiam amá-la muito e ela amaria seus pais? Por fazer uma escolha que ela nem sabe o que é o sentido daquilo tudo. Clonagem com animais seria bom, até que ajuda animais em extinção. Mas do ser humano não acho uma boa ideia ser um clone de alguém, acho que o clone gostaria de ter sua personalidade própria, não acha? Mesmo sendo réplica de alguém. Até os irmãos gêmeos pensam assim. (C3)

Foi realizado um teste de hipótese para verificar se a oficina alterou a opinião dos estudantes sobre serem contrários ou favoráveis a clonagem. O teste utilizado para verificar essa hipótese foi o teste de McNemar.

O teste foi aplicado sob as seguintes hipóteses:

$\mathrm{H}_{0}$ : A oficina não alterou a percepção dos estudantes serem contrários ou favoráveis a clonagem reprodutiva.

$\mathrm{H}_{1}$ : A oficina alterou a percepção dos estudantes serem contrários ou favoráveis à clonagem reprodutiva. 
O resultado do p-valor no teste foi 0.3588 , ou seja, menor que o nível de significância especificado de $5 \%$, o que indica que a oficina não alterou a percepção dos estudantes em relação a serem contrários ou favoráveis à clonagem reprodutiva.

Para a realização desse teste foram considerados apenas os estudantes que responderam serem contrários ou favoráveis em ambos os momentos (entrevista e QSC clonagem).

Em seguida, foi realizado um teste de hipótese para avaliar se houve mudança nas considerações morais dos estudantes. O teste utilizado para verificar essa hipótese foi o teste binomial.

O teste foi aplicado sob as seguintes hipóteses:

$\mathrm{H}_{0}$ : Não houve mudança nas considerações relativas ao domínio moral dos estudantes.

$\mathrm{H}_{1}$ : Houve mudança nas considerações relativas ao domínio moral dos estudantes.

O resultado do p-valor no teste foi 1 . Logo, teve-se evidências para não rejeitar a hipótese nula, isto é, que a oficina não proporcionou mudança nas considerações do domínio moral dos estudantes.

\subsubsection{QSC sobre terapia gênica}

A seguir serão apresentados os resultados obtidos por meio da análise descritiva e testes de hipótese para o tema terapia gênica.

\section{A - Conhecimento prévio sobre a biotecnologia}

O gráfico 19, na próxima página, apresenta os dados referentes a distribuição da frequência de estudantes que souberam ou não responder o que é terapia gênica e que não opinaram.

Na entrevista quando questionados se sabiam responder o que é terapia gênica apenas três de $60(5 \%)$ estudantes souberam responder, demonstrando possuir conhecimento prévio sobre o assunto. A maior parte 49 de $60(81,67 \%)$ não sabiam e oito de $60(13,33 \%)$ deixaram em branco ou não opinaram. 
Gráfico 19 - Distribuição da frequência de estudantes com conhecimento prévio sobre terapia gênica

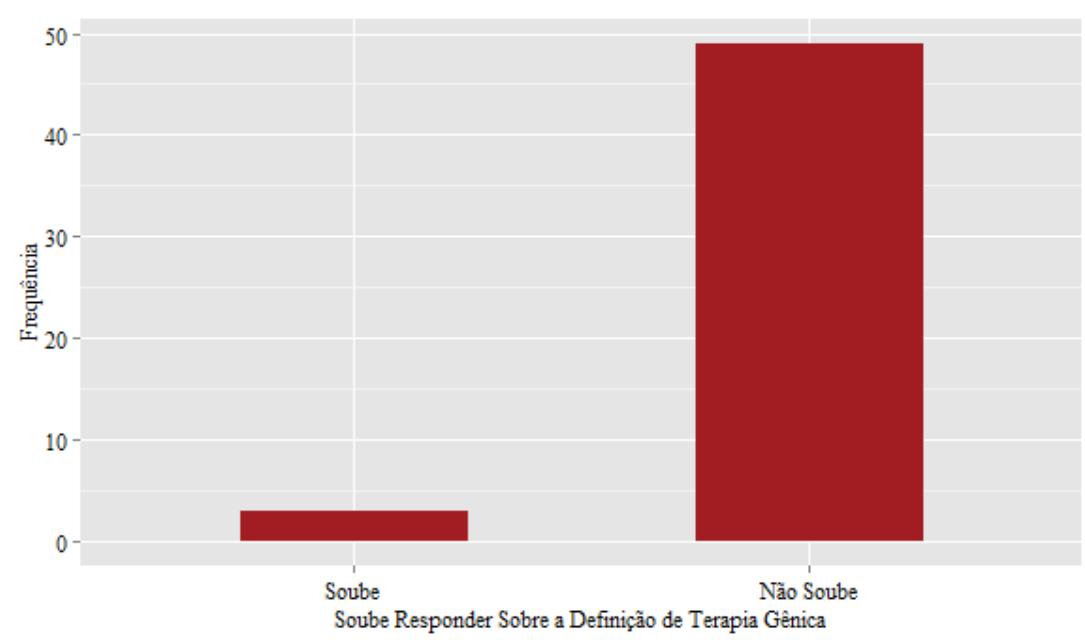

Fonte: elaboração da autora.

Ao contrário da clonagem poucos estudantes souberam responder o que é terapia gênica. Sugere-se que esse fato se deve a pouca divulgação desse tema pela mídia, no contexto escolar e em livros didáticos, daí o pouco conhecimento dos estudantes com o referido tema.

A seguir apresentamos exemplos de discursos de estudantes com conhecimentos prévios sobre o tema em questão.

Conhecimento prévio

ENT.: E terapia gênica já ouviu falar? B26: É tipo quando você consegue mudar o seu gene, mudando o seu DNA, RNA. É algo assim. É mais ou menos né!? [...] B26 ENT.: Tá. Você já ouviu falar sobre Terapia Gênica? C8: Já. ENT.: O quê que cê sabe sobre ela? C8: Que eles pegam tipo, vão passando de ano em ano quando, cara, não, terapia gênica? ENT.: É. C8: Que é tipo de nascença, modificar os genes do bebê, não, de uma pessoa, aí na hora que ela engravida o bebê é menos propenso à doença né? (C8)

ENT.: Terapia gênica, você sabe o que é? C11: Não, não, acho que mais ou menos. É aquilo que é para tratar de alguma doença dos genes [...] (C11)

Seguem-se exemplos de discursos de estudantes que disseram não possuíam conhecimento prévio sobre terapia gênica.

ENT.: Perfeito. E o que você entende por Terapia Gênica? A28: Também não sei. (A28)

ENT.: E terapia gênica? Você já tem uma ideia do que seja isso? B1: Olha eu posso saber mas eu não estou assimilando [...] (B1) 


\section{B - Opiniões contrárias ou favoráveis à aplicação da biotecnologia}

O gráfico 20 apresenta a opinião dos estudantes contrários ou favoráveis a terapia gênica.

Nenhum dos estudantes se mostrou contrário nos instrumentos utilizados previamente. Apenas dois de 60 (3,33\%) foram favoráveis ao uso da técnica. A maioria dos estudantes não apresentou argumentos suficientes para serem categorizados e oito de $60(13,33 \%)$ não opinaram.

Gráfico 20 - Distribuição da frequência de estudantes contrários, favoráveis e argumentos insuficientes sobre a terapia gênica

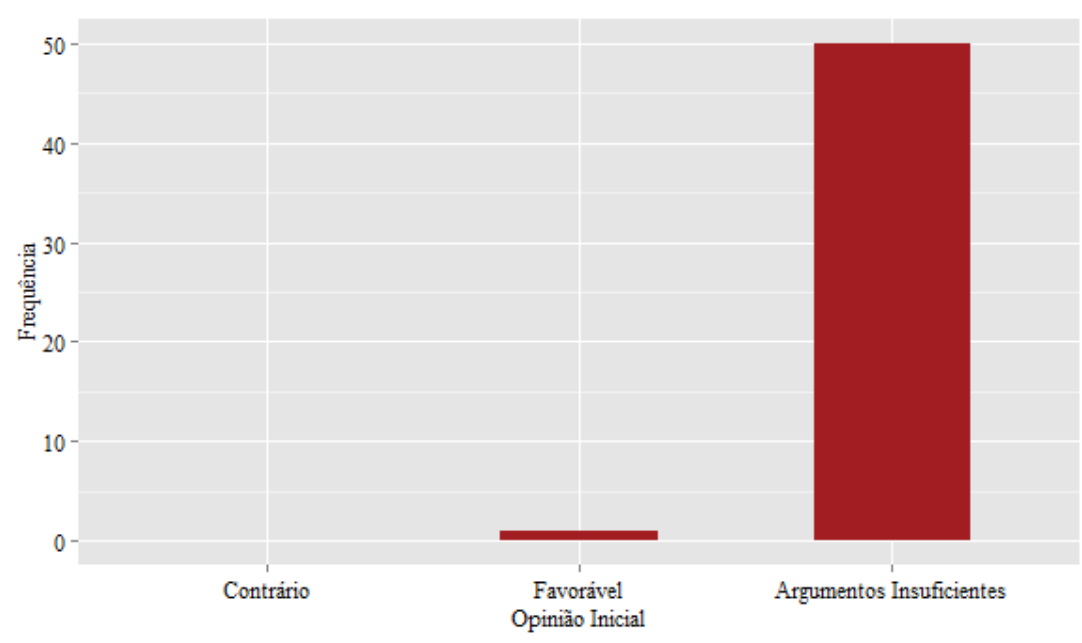

Fonte: elaboração da autora.

Como observou-se na entrevista a maioria dos estudantes não apresentaram argumentos suficientes para a categorização em relação a terapia gênica. Como dito anteriormente, o tema em questão é pouco explorado no contexto escolar, nos livros didáticos, e, também, na mídia o que dificulta o acesso dos estudantes ao conhecimento sobre esse tema.

No questionário foi feita a seguinte pergunta: "se fosse portador de uma doença genética você se submeteria a um tratamento para corrigir seus genes (terapia genética)?" A maior parte dos estudantes 53 de $60(88,33 \%)$ disseram que se submeteriam ao tratamento. Somente três de $60(5 \%)$ foram contrários e quatro de $60(6,67 \%)$ não opinaram ou deixaram em branco.

O gráfico 21, na próxima página, apresenta o resultado da análise dos estudantes contrários, favoráveis e em branco/não opinaram nos seguintes instrumentos: questionário, QSC albinis mo e QSC doping genético. 
Em relação as QSC a primeira sobre o albinismo apresentou os seguintes resultados. Pouco mais da metade dos entrevistados foram favoráveis, 31 de 60 (51,67\%). Oito de 60 $(13,33 \%$,$) deixaram em branco ou não opinaram e 21$ de 60 (35\%) foram contrários.

Na segunda QSC sobre o doping genético 42 de 60 (70\%) se mostraram contrários, quatro de $60(6,67 \%)$ foram favoráveis e 14 de 60 (23,33\%) deixaram em branco ou não opinaram.

Gráfico 21 - Distribuição da frequência dos estudantes contrários, favoráveis e em branco/não opinou sobre terapia gênica por instrumento

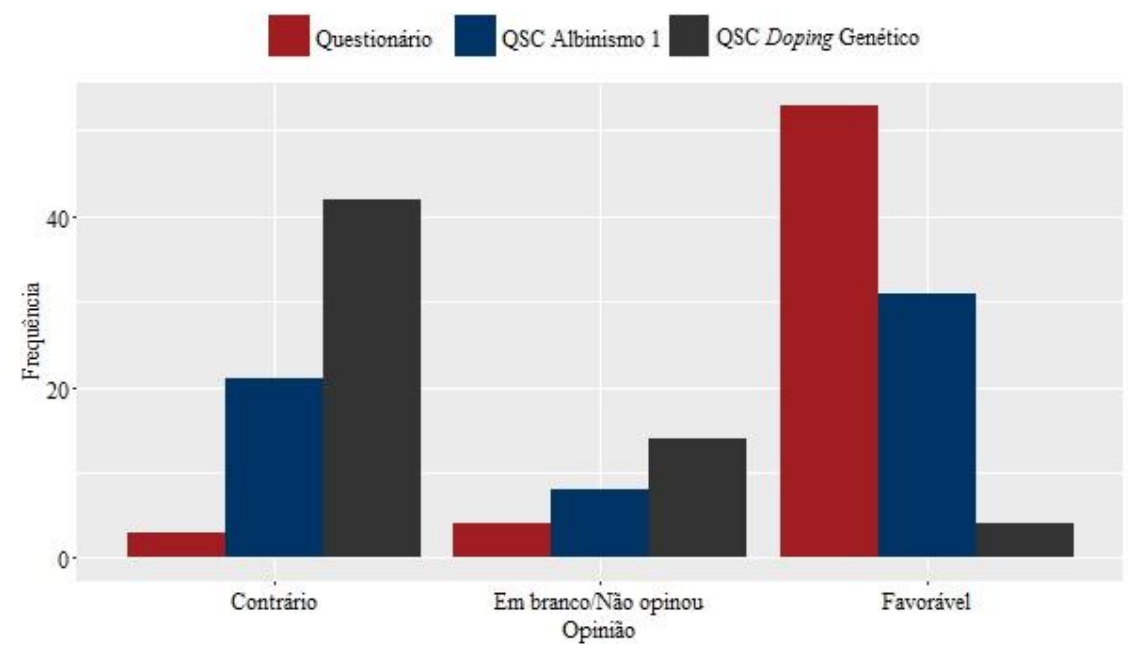

Fonte: elaboração da autora.

Na entrevista a maioria dos estudantes não sabiam responder o que é terapia gênica e não opinaram quanto a serem favoráveis ou contrários, entretanto no questionário quando questionados "se fosse portador de uma doença genética você se submeteria a um tratamento para corrigir seus genes? A maioria dos estudantes opinaram ser favoráveis ao tratamento.

Lee et al. (2005) apontaram que a ausência de conhecimento sobre uma tecnologia específica não impede a formação de atitudes ou percepções sobre ela., ou seja, os estudantes opinaram mesmo não tendo conhecimento sobre o tema terapia gênica. Ainda, Dawson e Schibeci (2003) se referiram ao fato de que atitudes e percepções, podem estar associadas a crenças e valores pessoais. Reiteramos o fato de que a relação entre o conhecimento científico e a atitude relacionada a biotecnologia é complexa.

Sugere-se que a adesão dos estudantes ao tratamento utilizando a técnica da terapia gênica parte de uma preocupação dos estudantes com a saúde e, consequentemente, com a vida, 
o que torna a terapia gênica uma aplicação biotecnológica mais aceitável do ponto de vista moral.

A seguir apresentamos exemplos de discursos contrários e favoráveis a terapia gênica.

$\underline{\text { Contrário }}$

Não, pois acredito na seleção natural. (C80

Não acho necessário um tratamento genético nesse caso, visto que o problema em questão é a falta de respeito e a falta de aceitação entre as pessoas. (B21)

$\mathrm{Eu}$ acho que a partir do momento que usamos o doping genético, a gente deixa de praticar o verdadeiro esporte, então acho melhor ele ir só com o seu corpo mesmo que não ganhe o campeonato. (C19)

$\underline{\text { Favorável }}$

[...] ENT.: Essa você é contra ou a favor? C8: Eu sou a favor. ENT.: Por quê? C8: Assim evita, deixa as pessoas mais resistentes à vírus, contágio. (C8)

Sim, por que hoje a doença está muito avançada e até que eu poderia conseguir viver bem. (D14)

Não, pois albinismo não é um caso que necessita de correção, é só forma, alguns cuidados, pois é uma pele muito frágil. (D25)

Sim, por que aumentará suas chances de vencer. (E26)

\section{C - Domínio moral}

O gráfico 22, na próxima página, apresenta os resultados da distribuição de frequência das considerações acerca do domínio moral, não moral, em branco/não opinou e argumentos insuficientes por instrumento aplicado.

As análises para considerações relativas ao domínio moral foram realizadas tendo como base cinco instrumentos de análise: entrevista, questionário, QSC albinismo questão 1, QSC albinismo questão 2 e QSC doping genético. Em relação a entrevista 55 de 60 (91,67\%) não souberam responder, cinco de 60 (8,33\%) apresentaram considerações acerca do domínio moral e para esse instrumento não houve considerações relacionadas ao domínio não moral, nem argumentos insuficientes. Em relação ao questionário 56 de 58 (93,33\%) apresentaram considerações do domínio moral, não houve respostas com considerações relativas ao domínio não moral, dois de 60 (3,33\%) deixaram em branco ou não opinaram e dois de 60 (3,33\%) apresentaram argumentos insuficientes para categorizar.

Quanto à primeira questão da QSC sobre o albinismo não houve respostas com considerações não morais, sete de 60 (11,67\%), deixaram em branco ou não opinaram, 45 de 
$60(85 \%)$ dos respondentes apresentaram considerações morais e oito de 60 (3,33\%) não apresentaram argumentos suficientes para serem categorizados. Na segunda questão da QSC sobre o albinismo 58 de $60(96,67 \%)$ apresentaram considerações morais e dois de $60(3,33 \%)$ deixaram em branco ou não opinaram.

Em relação à QSC sobre o doping genético 12 de 60 (20\%) não responderam ou deixaram em branco, não houve respostas relacionadas ao domínio não moral, 42 de 60 (70\%) apresentaram discursos relacionados ao domínio moral e seis de 60 (10\%) não tivram argumentos suficientes para serem categorizados.

Gráfico 22 - Distribuição da frequência de estudantes que apresentaram considerações relativas ao domínio moral, não moral, em branco/não opinaram e argumentos insuficientes

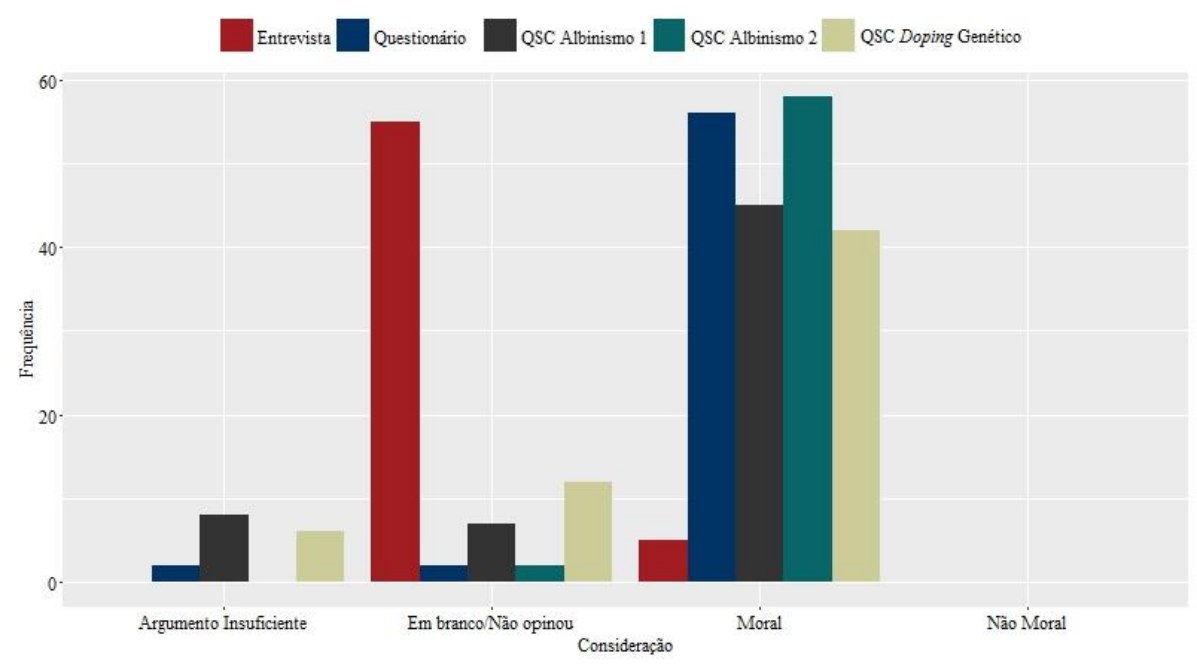

Fonte: elaboração da autora.

A partir da análise dos resultados percebeu-se que os estudantes tomaram decisões em relação a terapia gênica com base no domínio moral. Em relação a esse tema não houve considerações relativas ao domínio não moral. Esse dado corrobora com os encontrados nos estudos de (ver, por exemplo, FOWLER; ZEIDLER; SADLER, 2009; MUELLER; ZEIDLER, 2010; SADLER; FOWLER, 2006; SADLER, 2004a e b; WALKER; ZEIDLER, 2007; ZEIDLER; KEEFER, 2003).

Para exemplificar o domínio moral, apresentamos os discursos a seguir.

$\underline{\text { Domínio moral }}$

B17: Terapia gênica? ENT.: Isso. B17: Mais ou menos. ENT.: E você é contra ou a favor a terapia gênica? Terapia gênica, genética.... B17: Eu sou a favor. ENT.: Por que? B17: Porque eu acredito que seja por uma boa causa, para ajudar assim, se a 
pessoa tiver algum problema assim de saúde precisa da terapia gênica acho poderia ajudar a pessoa normalmente. (B17)

$\mathrm{Sim}$, pois isso traria somente benefícios a mim. (C22)

O albinismo causa muitas dificuldades na vida de uma pessoa e pode trazer outras doenças, portanto acredito que se irá ajudar a pessoa a ter uma vida melhor deve sim ser usada. (E1)

Bom, aí vinha de cada pessoa, se ela quer conviver com aquilo ou ter uma saúde perfeita. (E12)

Ele deve decidir se sim ou não, porém defendo a tese de que todo atleta deve conseguir suas provas de forma natural física do corpo. (B6)

\section{D - Julgamento moral}

Os discursos dos estudantes que apresentaram considerações relacionadas ao domínio moral foram categorizados de acordo com o tipo de teoria moral evocada: deontológica, utilitarista, ceticismo moral ou argumentos insuficientes.

O gráfico 23, na próxima página, apresenta o resultado das análises sobre a teoria moral utilizada para responder as questões apresentadas nos instrumentos de coleta dos dados.

$\mathrm{Na}$ entrevista todos os estudantes que apresentaram discursos relacionados ao domínio moral cinco $(100 \%)$ realizaram o julgamento apoiados na moral utilitarista. No questionário 53 de $56(94,64 \%)$ apresentaram um discurso moral utilitarista e apenas três de $56(5,36 \%)$ responderam com base na teoria moral deontológica.

Na QSC sobre o albinismo (primeira questão) 27 de 47 (57,45\%) responderam de acordo com a moral deontológica, $17(36,18 \%)$ responderam com base na moral utilitarista e um estudante $(2,12 \%)$ não apresentou argumento suficiente ser categorizado. Na questão 2 da QSC sobre o albinismo, a maioria dos estudantes 51 de 63 (80,95\%) responderam com base em uma moral deontológica e 12 dos $63(19,05 \%)$ na moral utilitarista, sendo que três estudantes consideraram os dois tipos de moral deontológica e utilitarista.

Em relação a QSC sobre o doping genético a maioria dos estudantes 35 de 43 $(81,39 \%)$ apresentaram considerações com base na moral deontológica, seis de $43(13,95 \%)$ apresentaram considerações morais utilitaristas. 
Gráfico 23 - Frequência de estudantes que responderam as questões com base nas teorias morais deontológica, utilitarista, ceticismo moral e argumento insuficiente

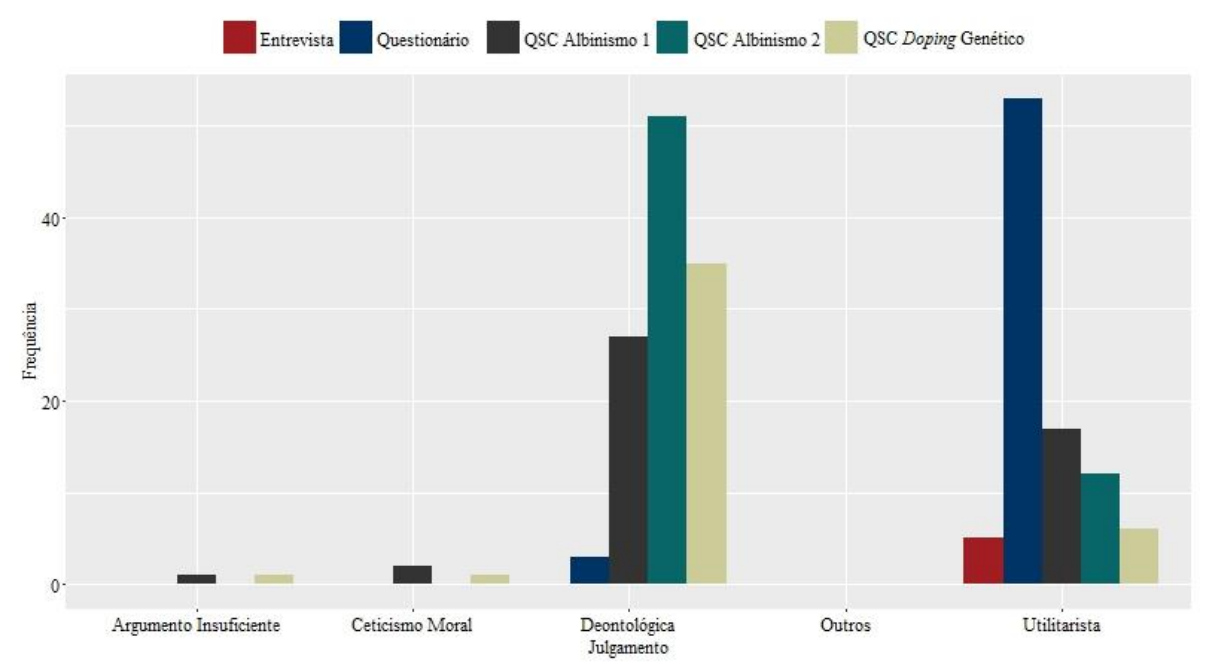

Fonte: elaboração da autora.

A partir da análise dos resultados observou-se que a maioria dos estudantes apresentaram uma moral utilitarista na entrevista e no questionário. Entretanto, nas QSC sobre o albinismo questão 1 e 2 e na QSC sobre o doping genético a maioria dos estudantes apresentaram uma moral deontológica.

Os resultados das análises de categorias de julgamento moral diferiram muito entre os transgênicos, clonagem e a terapia gênica. Nos transgênicos a moral utilitarista prevaleceu no julgamento dos estudantes, enquanto na clonagem e nas QSC sobre terapia gênica a moral deontológica foi predominante. A moral deontológica se baseia em normas estabelecidas aprioristicamente considerando apenas a intenção do ato, não o resultado, ao contrário da utilitaris ta que se baseia na avaliação das consequências.

Com esses resultados, percebemos que apesar das pessoas verem a moralidade como normas rígidas, objetivas e universais, o julgamento moral dos estudantes apresentou uma flexibilidade. Bartels et al. (2014) se refere ao fato do mundo moral ser extremamente complicado e que as pessoas apresentam diferentes formas de alcançar consistência lógica para justificar suas crenças.

A flexibilidade moral refere-se à ideia de que as pessoas são frequentemente motivadas a fazer a coisa certa, mas um determinado princípio moral pode dar origem a julgamentos morais diferentes, portanto a compreensão do julgamento moral necessita de modelos que considerem dois aspectos, o tomador de decisão moral e do contexto em que suas decisões têm 
lugar. Maior parte do comportamento humano é o produto conjunto da pessoa e da situação (BARTELS et al., 2014).

Pesquisas apontam (ver, por exemplo, Greene, 2007; Greene et al., 2001) que os processos cognitivos são controlados por escolhas de maximização do bem-estar, ou seja, utilitários e que processos emocionais são responsáveis por escolhas automáticas que correspondem a normas deontológicas.

A seguir apresentamos exemplos de discursos relacionados a moral deontológica, utilitaris ta e ceticismo moral.

Moral deontológica

Não, por que o destino quis assim não devemos interferir. (C11)

Não, pois acredito na seleção natural. (C8)

Creio que sim, esse é o desejo, a vontade do garoto e ele deve ser respeitada. Necessita de correção apenas para os que desejam tê-la, e não de uma maneira geral. (B10)

Acho que deveriam desenvolver o tratamento, mas só ser usado caso a pessoa ou a família quiser, e a sociedade deveria aceitar as diferenças. (B22)

$\mathrm{Eu}$ aconselharia que ele não fizesse esse procedimento, pois acredito que seja trapaça, não é o melhor a fazer, ele também perderia todo o seu mérito. (B21)

$\underline{\text { Moral utilitarista }}$

ENT.: Tá. Você já ouviu falar sobre Terapia Gênica? C8: Já. Shirley: O quê você sabe sobre ela? C8: Que eles pegam tipo, vão passando de ano em ano quando, cara, não, terapia gênica? ENT.: É. C8: Que é tipo de nascença, modificar os genes do bebê, não, de uma pessoa, aí na hora que ela engravida o bebê é menos propenso à doença né? ENT.: Pode modificar, é. C8: A, então é isso, tava pensando em outro. ENT.: Essa você é contra ou a favor? C8: Eu sou a favor. ENT.: Por quê? C8: Assim evita, deixa as pessoas mais resistentes à vírus, contágio. (C8)

Sim, pois tudo aquilo que for benefício a ajudar dentro de uma doença eu sou a favor. (A28)

$\mathrm{X}$ estava se sentindo muito mal, deveria se submeter sim, pois o que ele tem é algo muito ruim que não afeta só fisicamente, mas também psicologicamente. Ele teria melhorado sua autoestima, vivido melhor e feliz após o tratamento. (B9)

Deveria sim investir em pesquisas para achar uma solução para o albinismo até por que mesmo a sociedade aceitando a pessoa com albinismo, ela mesma se sentindo diferente das outras não se aceitaria a si mesma. (E19)

Para não tomar este remédio, pois irá trazer doenças a ele, e quando ele fizer os testes pode ver que ele está tomando o remédio. (C1) 


\section{Ceticismo moral}

Sim, por que aumentará suas chances de vencer. (E26)

Não, o X nasceu com albinismo e seria impossível essa mudança na pigmentação dele. B26

Que ele utilizasse o doping, pois melhora muito o desempenho do atleta, porém o risco de ser pego no exame é muito grande e será banido de algum atleta. D25

\section{E - Princípio moral}

O gráfico 24 apresenta os princípios utilizados para justificar o julgamento moral. Importante ressaltar que mais de um princípio pode ter sido utilizado pelo mesmo estudante, por isso os totais não são iguais. Para a categorização dos discursos foram utilizados alguns princípios da Declaração Universal de Bioética e de Direitos Humanos (UNESCO, 2005) e no caso do doping genético alguns Valores do Espírito do Desporto (WADA, 2003).

Gráfico 24 - Distribuição da frequência de princípios morais utilizados pelos estudantes ao responder aos instrumentos do estudo

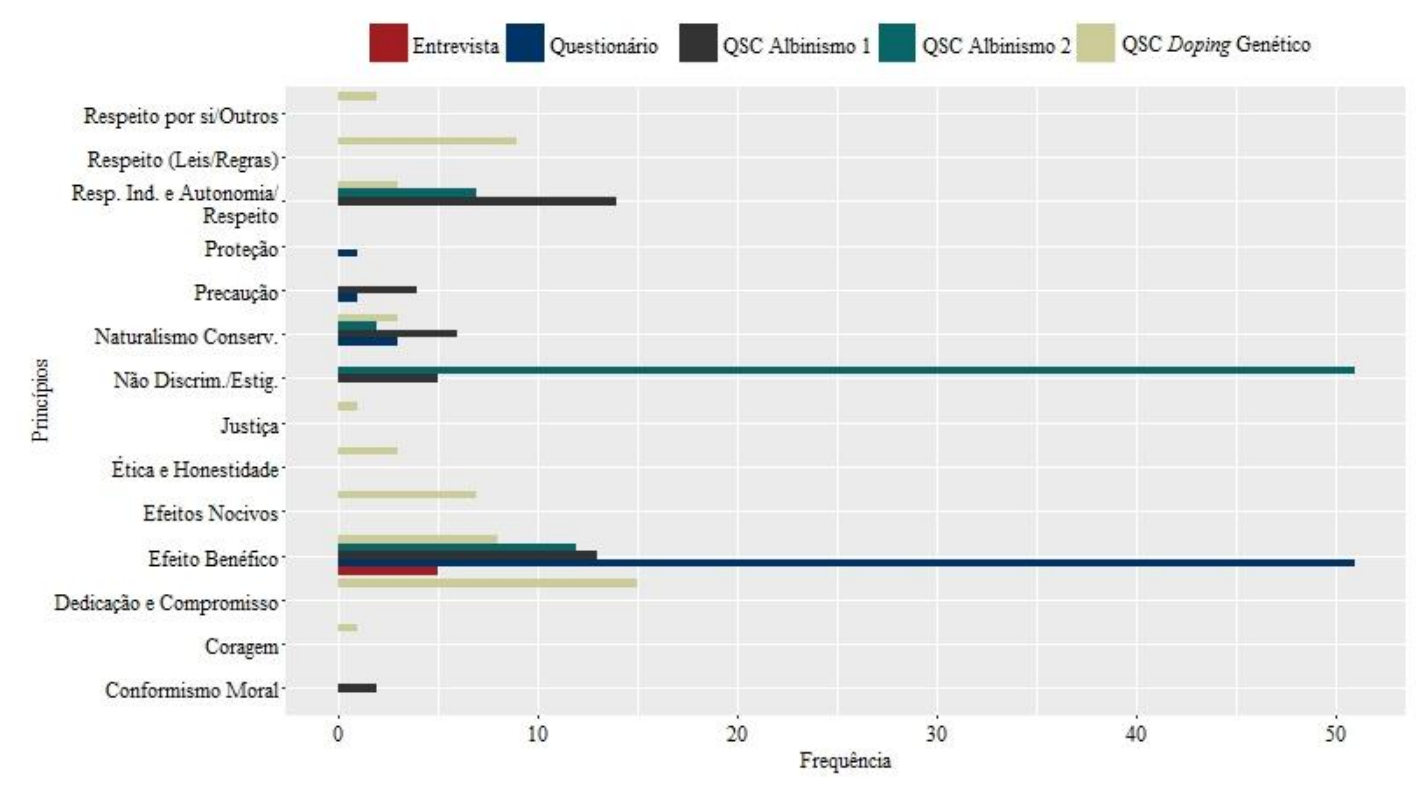

Fonte: elaboração da autora.

$\mathrm{Na}$ entrevista todos os estudantes que apresentaram considerações morais justificaram seu argumento com base no princípio efeitos benéficos. No questionário 51 de $56(91,07 \%)$ dos estudantes utilizaram o princípio efeitos benéficos, três de $56(5,36 \%)$ se basearam no princípio naturalismo conservadorista, o princípio precaução foi utilizado por um estudante $(1,79 \%)$ e o princípio proteção das gerações futuras, também foi utilizado por apenas um estudante $(1,79 \%)$. 
Na QSC sobre o albinismo (questão 1) 13 de 44 (29,54\%) se referiram ao princípio efeito benéfico, seis de $44(13,63 \%)$ utilizaram o princípio naturalismo conservadorista, 14 de $44(31,81 \%)$ apresentaram o princípio autonomia e respeito a individualidade humana, quatro de $44(9,10 \%)$ expressaram precaução, cinco de $44(11,36 \%)$ apontaram não discriminação e não estigmatização e dois de 44 (4,54\%) expressaram conformismo moral. Na QSC sobre o albinismo (questão 2) 51 de $72(70,83 \%)$ apresentaram o princípio ético não discriminação e não estigmatização, sete de $72(9,73 \%)$ utilizaram o princípio autonomia e responsabilidade individual e dois de $72(2,78 \%)$ expressaram naturalismo conservadorista.

Na QSC sobre doping genético, a maior frequência, oito de 52 (15,38\%) apresentaram o princípio efeito benéfico, três de $5(5,77 \%)$ apresentaram o princípio naturalismo conservadorista, três de $52(5,77 \%)$ utilizaram o princípio autonomia e responsabilidade individual, três de $52(5,77 \%)$ utilizaram o princípio ética e honestidade, nove de $52(17,30 \%)$ apresentaram o princípio respeito pelas leis e regras, 15 de $52(28,86 \%)$ apresentaram o princípio dedicação e compromisso e um de 53 (1,92\%), dois de $53(3,8 \%)$ apresentou o princípio respeito por si e pelos outros.

Percebeu-se que que na QSC sobre o albinismo os princípios mais utilizados pelos estudantes foram: efeitos benéficos, não discriminação e não estigmatização e autonomia e responsabilidade individual.

Os princípios morais servem como uma referência por meio da qual podemos avaliar e direcionar nossas ações. Princípios morais são diferentes dos princípios científicos, que nos permitem uma avaliação rápida e decisiva em relação a determinadas questões. Esses são menos propensos a nos dar uma resposta correta, mas podem ser usados para avaliar situações conflitantes, um processo de tomada de decisão.

A seguir apresentaremos alguns exemplos de discursos dos estudantes para exemplificar as categorias adotadas.

\section{$\underline{\text { Autonomia e responsabilidade individual }}$}

Creio que sim, esse é o desejo, a vontade do garoto e ele deve ser respeitada. Necessita de correção apenas para os que desejam tê-la, e não de uma maneira geral. (B10) 
$\underline{\text { Efeito benéfico }}$

Sim, pois tudo aquilo que for benefício a ajudar dentro de uma doença eu sou a favor. (A28)

\section{$\underline{\text { Naturalismo conservadorista }}$}

Não a problemas e sim ao natural. (E6)

\section{Precaução}

Não sei se teria coragem. (C4)

$\underline{\text { Proteção das gerações futuras }}$

Sim para evitar que no futuro meu filho tenha. (E28)

$\underline{\text { Não discriminação e não estigmatização }}$

As diferenças têm que ser aceitas, o albinismo é genético e pode ocorrer. (A1)

\section{Conformismo moral}

Os problemas que não podem ser solucionados podem fazer mal e dá para conviver com eles. (B24)

\section{Ética e honestidade}

A decisão do uso de doping (nos meus conceitos de ética) é a assinatura do fracasso. Não sei qual seria a definição de ética do X. (B1)

\section{$\underline{\text { Respeito pelas leis e pelas regras }}$}

$\mathrm{Eu}$ aconselharia que ele não fizesse esse procedimento, pois acredito que seja trapaça, não é o melhor a fazer, ele também perderia todo o seu mérito. (B21) 


\section{$\underline{\text { Dedicação e compromisso }}$}

Não usar o doping genético o esforço tinha que ser natural com muito treinamento todos nós conseguimos atingir nossas metas. (C5)

\section{$\underline{\text { Coragem }}$}

Deverá mudar sua determinação interna e seu pensamento. E não fugir dos problemas e tentar mudar a situação apenas pelo externo. (C2)

Efeitos nocivos

Acho que ele não deveria usar, pois se ele é pego no antidoping ele nem vai poder competir, fora que pode causar danos a sua saúde. (E25)

$\underline{\text { Justiça }}$

Não é um fator genético dele, ele já está em seu limite, fazer esse doping seria algo ganancioso e injusto com outros atletas, visto que nem todos possuem poder monetário para o procedimento. (B14)

\section{$\underline{\text { Respeito por si e pelos outros }}$}

Não optar pelo doping, já que o corpo dele não aguenta mais os exercícios é hora de parar e dar a vez para outros atletas. (C13)

Foram realizados dois testes de hipóteses para verificar se a oficina modificou a percepção dos estudantes em serem contrários ou favoráveis a terapia gênica. Os testes utilizados para realizar essa análise foram o teste de McNemar e o teste binomial.

As variáveis testadas foram: entrevista $\mathrm{x}$ albinismo questão 1, entrevista $\mathrm{x}$ albinis mo questão 2, questionário x albinismo questão 1 e questionário $\mathrm{x}$ albinismo questão 2.

Os testes foram aplicados sob as seguintes hipóteses:

$\mathrm{H}_{0}$ : Não houve mudança na percepção contrária dos estudantes.

$\mathrm{H}_{1}$ : Houve mudança na percepção contrária dos estudantes.

Após a realização dos testes explicitados acima, os resultados de p-valor para cada um estão apresentados no quadro 16. 
Quadro 16-P-valores dos testes realizados

\begin{tabular}{lcc}
\hline \multicolumn{1}{c}{ Testes } & p-valor & Decisão \\
\hline Entrevista x albinismo 1 & 1 & Não Significativo \\
\hline Entrevista x albinismo 2 & 0,5 & Não Significativo \\
\hline Questionário x albinis mo 2 & $<0,0001$ & Significativo \\
\hline Fonte: elaboração da autora. & & \\
\hline
\end{tabular}

Para os dois testes que envolveram a entrevista houve uma intercorrência relacionada ao fato de 50 estudantes não terem apresentado argumentos suficientes para serem categorizados como contrários ou favoráveis a terapia gênica, e outros oito estudantes não terem respondido, assim essas variáveis não foram incluídas no cálculo. Nesse contexto, no cálculo da matriz do teste de McNemar não se rejeita a hipótese nula com p-valor igual a 1 e 0,5 no primeiro e segundo testes, respectivamente.

O teste questionário $\mathrm{x}$ QSC albinismo questão 1 não está na tabela, pois não foi observada mudança de opinião por parte dos estudantes na matriz construída, o que impossibilitou o cálculo do p-valor. Já para o último teste, questionário x QSC albinis mo questão 2, houve evidências estatísticas suficientes para a rejeição da hipótese nula.

Em seguida, o mesmo teste foi aplicado para verificar se a oficina modificou os discursos relacionados ao domínio moral dos estudantes.

Os testes considerados foram: entrevista x QSC albinismo questão 1, entrevista x QSC albinis mo questão 2, entrevista x QSC doping genético, questionário x QSC albinismo questão 1, questionário x QSC albinismo questão 2 e questionário x QSC doping genético.

Os testes foram aplicados sob as seguintes hipóteses:

$\mathrm{H}_{0}$ : Não houve mudança nas considerações relacionadas ao domínio moral dos estudantes.

$\mathrm{H}_{1}$ : Houve mudança nas considerações relacionadas ao domínio moral dos estudantes.

Como não houve mudança de opinião relativas ao domínio moral dos estudantes o teste não gerou p-valor em todos os casos, ou seja, não houve alterações no domínio moral dos estudantes.

Em resumo, para clonagem reprodutiva tem-se que, após obter as respostas para saber se os estudantes eram contrários ou favoráveis à clonagem, foram realizados os testes de McNemar e binomial e o resultado obtido indicou que a oficina alterou a opinião dos estudantes serem contrários a clonagem reprodutiva. Em relação as considerações do domínio moral 
realizando os mesmos testes de hipóteses, foi possível obter resultados que permitem dizer que não houve mudança nas considerações relacionadas ao domínio moral dos estudantes.

Para a terapia gênica: foram realizados os mesmos testes de hipóteses em relação a opinião dos estudantes antes e depois da oficina. Os resultados demonstraram não haver evidências suficientes para afirmar que a oficina mudou a opás inião dos estudantes quanto a serem contrários ou favoráveis e, também suas considerações do domínio moral. Somente no caso do teste questionário x QSC albinismo (questão 2) a hipótese nula foi rejeitada, ou seja, a oficina modificou a opinião dos estudantes quanto a serem contrários ou favoráveis.

\subsection{Reflexões sobre implicações pedagógicas}

As aulas em que foram discutidos os dilemas foram gravadas em vídeos e a partir das anotações da memória de campo foi selecionada uma aula para a transcrição e análise textual discursiva. O critério de seleção desta aula foi em função de ser a mais representativa em termos de participação dos estudantes e mais fácil de transcrever, devido a existência de ruídos e da qualidade da imagem.

A partir dos resultados obtidos já analisados e da participação dos estudantes na discussão dos dilemas, foram feitas reflexões sobre as implicações pedagógicas da abordagem de aspectos morais em QSC de biotecnologia. A partir dessas reflexões realizou-se uma caracterização das implicações pedagógicas de aspectos morais quanto: ao desenvolvimento das sequências didáticas, ao conteúdo pedagógico, ao quadro moral, às estratégias didáticas, envolvendo aspectos morais, ao currículo e à formação de professores.

\subsubsection{Desenvolvimento das sequências didáticas de QSC e a participação dos estudantes na discussão dos dilemas}

Um planejamento inicial foi feito para desenvolver as SD em 40 aulas, nas quais estavam previstas: 20 aulas teóricas e 20 aulas para o desenvolvimento de estratégias didáticas variadas que incluíam debates, discussões, jogo de interpretação de papéis, utilização de filmes e documentários etc. Entretanto, não foi possível utilizar o planejamento inicial, devidos interrupções do calendário escolar como semana de provas, conselho de classe, paralisações e greve dos professores que durou cerca de 30 dias. Nesse interim houve constantes interrupções das aulas pelo professor efetivo das turmas que, por vezes, duravam cerca de $20 \mathrm{~min}$. a 30min. Com a redução das aulas, o planejamento foi revisto e resultou em 26 aulas, o que levou a uma redução no desenvolvimento das estratégias didáticas e a um predomínio de aulas teóricas em 
busca de introduzir a informação científica sobre as aplicações da biotecnologia elencadas, os usos correntes e as implicações morais relacionadas.

O principal efeito dessa mudança se deu no fato de que os dilemas que inicialmente estavam previstos para serem abordados no primeiro semestre só foram introduzidos no final do ano. Isso contribuiu para uma maior ausência dos estudantes nas discussões dos dilemas, uma vez que a frequência às aulas diminui em função da proximidade do recesso escolar.

O número de estudantes frequentes na disciplina foi de aproximadamente 120. Surge aqui um complicador: como o componente curricular PD é conhecido pelos estudantes como uma disciplina que não reprova, os mesmos não realizaram as atividades propostas em sala de aula e muitas vezes faltaram as aulas. Mesmo estando na escola muitos desses estudantes não compareciam as aulas. Essa característica fez com que o tamanho da amostra ficasse pequeno. O tamanho amostral constituiu outra limitação deste estudo, uma vez que impossibilitou a análise quantitativa dos dados por meio de testes paramétricos e a possibilidade de fazer inferências.

Uma das hipóteses da não frequência dos estudantes nas aulas, está no fato de os estudantes terem uma expectativa de ficarem mais "livres" na disciplina de PD e não de ficarem assistindo aula com conteúdo de Biologia e participarem de atividades como discussão e atividades escritas.

Considerando, que os estudantes não tinham como pré-requisito conceitos específicos de genética, então foi previsto no planejamento didático aulas de revisão de conceitos e processos apresentados no módulo 1 da oficina. A estratégia de ensino para introdução dos conceitos de genética foi aula expositiva dialogada e para o trabalho com QSC foi discussão com exceção das questões relacionadas à terapia gênica. A discussão das QSC foi realizada com todas as turmas que participaram do estudo.

Na figura 6, apresentamos o resultado da análise realizada com uma turma na discussão com a QSC sobre milho transgênico. 
Figura 6 - Tempo de fala do professor e dos estudantes

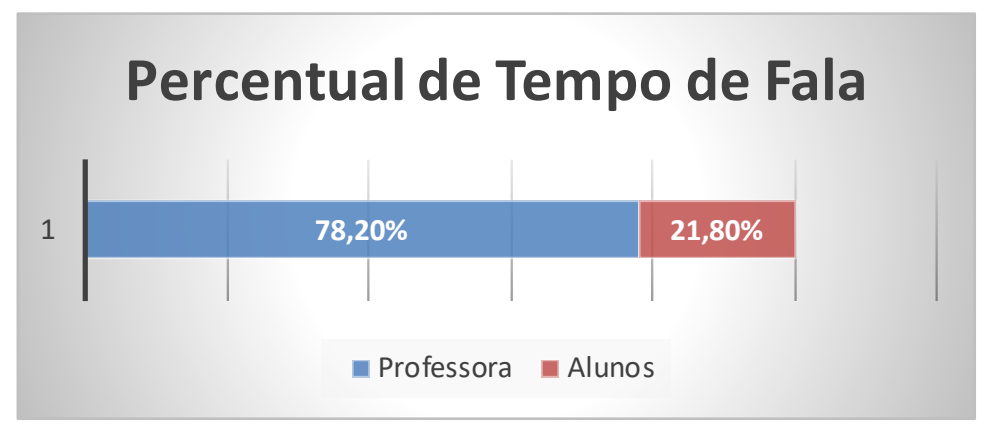

Fonte: elaboração da autora.

O trecho teve duração de $31 \mathrm{~min}$. e 11 seg. (Figura 6) observou-se pelos dados apresentados que na maior parte do tempo da prevaleceu a fala da professora pesquisadora, que procurava embasar os estudantes para a discussão, apontando aspectos positivos e negativos do uso de transgênicos e motivando os estudantes a emitirem suas opiniões sobre a QSC em discussão (milho transgênico). As interações discursivas foram agrupadas em cinco categorias, conforme tabela 4. $\mathrm{Na}$ análise, observou-se que apesar de a professora pesquisadora ter feito várias intervenções para engajar os estudantes na discussão, a participação deles não foi expressiva.

Tabela 4 - Categorias da análise dos discursos da professora e dos estudantes

\begin{tabular}{lc}
\hline \multicolumn{1}{c}{ Categorias } & $\begin{array}{c}\mathbf{N}^{\circ} \text { de } \\
\text { intervenções }\end{array}$ \\
\hline Discurso dialógico & 13 \\
\hline Intervenção do profes sor para engajar o estudante no debate & 16 \\
\hline Discurso de autoridade & 3 \\
\hline Ponto de vista do estudante & 33 \\
\hline Pergunta do estudante para o professor & 9 \\
\hline Fonte: elaboração da autora.
\end{tabular}

Nas discussões, a professora oportunizou a verbalização e utilizou estratégias para favorecê-la. No entanto, a condução do discurso foi predominantemente explicativa, visando à ampliação do conhecimento sobre o conteúdo, por entender que a pouca participação dos estudantes estava relacionada à falta de conhecimento, mesmo após a realização da SD. Promover a argumentação implica em romper com essa prática, o que não é simples, mesmo 
para professores propensos a vivenciar novas propostas metodológicas em sua atividade docente, como a professora pesquisadora.

A partir da transcrição e da análise realizada, observou-se que na maioria das vezes em que os estudantes se posicionaram foi para expressar suas opiniões sobre a QSC proposta. Essa foi a primeira discussão realizada com os estudantes pela professora pesquisadora. Além desse fato os estudantes que contribuíram com a discussão foram cerca de quarto ou cinco e sempre os mesmos, ou seja, não houve uma ampla participação da turma. Notou-se em todas as turmas resultado semelhante.

Nesse contexto, levantou-se algumas hipóteses para explicar o pouco engajamento dos estudantes na discussão. Dentre elas, a dificuldade da professora pesquisadora desse tipo de atividade. Outra hipótese é a pouca realização desse tipo de atividade por parte dos professores da escola, percebeu-se, então, que na escola existe pouco espaço para o protagonismo estudantil, além de as atividades propostas terem sido encaradas pelos estudantes como meras conversas informais.

\subsubsection{Estratégias didáticas para introdução de QSC, envolvendo aspectos morais}

Neste estudo, utilizou-se aulas teóricas, apresentação de vídeos e discussão como estratégias didáticas, devido ao pouco tempo disponível para a realização da oficina. As aulas planejadas para a abordagem dos dilemas estavam centradas na exploração do conhecimento científico e implicações morais relacionadas aos dilemas que seriam discutidos. Nessas aulas houve pouca participação dos estudantes, consideramos que se tivéssemos tido tempo para o desenvolvimento de todas as atividades previstas inicialmente os estudantes poderiam ter tido uma maior participação nas discussões dos dilemas. Também poderíamos ter reduzido a quantidade de temas, mas devido a um acordo prévio com a escola essa modificação não foi possível.

Os poucos trabalhos com propostas pedagógicas sobre QSC e moral (ver, por exemplo, SAUNDERS; RENNIE, 2013 e LEE et al. 2012b) apontaram que essas questões requerem a adoção de estratégias de ensino variadas tais como: discussões, debates, jogo de interpretação de papéis (role play), júri simulado, a leitura de materiais diversificados sobre o assunto, discussões em pequenos grupos, vídeos, além do desenvolvimento do conteúdo em sala de aula. Entretanto, a aplicação dessas atividades requer tempo, planejamento e habilidade por parte do professor. Assim, o currículo extenso e a pequena quantidade de aulas constituem obstáculos para os professores desenvolverem esse tipo de trabalho, pois, nesse contexto, os professores 
precisam ser criativos quanto à utilização do tempo e às estratégias que envolvam diretamente os estudantes.

\subsubsection{Abordagem de aspectos morais}

Neste estudo, fizemos a inclusão de um quadro moral que consistiu na análise das implicações morais de cada uma das aplicações da biotecnologia trabalhadas esclarecendo sobre os riscos e benefícios, direitos e deveres e virtudes como a honestidade, integridade e compaixão. Entretanto, não utilizamos nenhum modelo de tomada de decisão moral.

Quanto à abordagem de aspectos morais considera-se que existem quatro elementos principais que devem ser priorizados para se alcançar uma discussão que envolva a moralidade com sucesso:

1. a preparação do professor;

2. as estratégias utilizadas em sala de aula;

3. a integração do quadro moral; e

4. a apresentação de um modelo de tomada de decisão moral.

O primeiro elemento a ser considerado é a preparação do professor para abordar temas controversos, uma vez que as QSC são dependentes do contexto, permitem uma diversidade de pontos de vista, requerem consciência da acerca da natureza da ciência, além de uma preparação sobre princípios morais, bioéticos básicos que sem dúvida, farão o professor se sentir mais confiante para discutir questões morais, como as utilizadas em nosso estudo.

Para a atuação com QSC o professor deve colocar perguntas breves e concisas, estar preparado para reformular as perguntas, para elaborar novas respostas dos participantes, saber usar diferentes técnicas, redirecionar perguntas e respostas, dar retorno e reforço sem respostas repetitivas e direcionar questões para a turma.

O segundo elemento é a seleção e integração de estratégias de ensino que permitam uma participação mais efetiva dos estudantes nas aulas. Salienta-se que a utilização dos quadros morais em apoio ao processo de raciocínio e tomada de decisão moral, precisaser complementada por estratégias de ensino que envolvam atividades escritas ou discursivas. $\mathrm{O}$ trabalho com QSC e moral exige o desenvolvimento de certas habilidades como: leitura e compreensão das questões; para tanto é necessária a compreensão sobre o tema tratado (conhecimento do tema); o desenvolvimento de habilidades discursivas, tanto faladas quanto escritas para que os estudantes saibam como elaborar um argumento e que esse não incorra em 
falácias e a metacognição que favorece o juízo reflexivo, o pensamento crítico, a tomada de decisão e a resolução de problemas.

O terceiro elemento que deve ser considerado é a integração de um quadro moral nas aulas, para que os estudantes possam analisar as questões, por exemplo, riscos e benefícios, justiça, bem-comum, virtudes éticas etc.

O quarto elemento, de fundamental importância é a elaboração de um modelo de tomada de decisão que permita aos estudantes levantarem os fatos relevantes, as pessoas envolvidas que possam ser afetadas pela decisão, os valores envolvidos na questão, as possíveis soluções, a decisão e a justificação. Conforme exemplo a seguir:

Primeiro passo: reconhecendo uma questão moral

- Essa decisão ou situação poderia ser prejudicial a alguém?

- Essa decisão envolve a escolha entre o bem e o mal?

$\underline{\text { Segundo passo: analisando os fatos }}$

- Quais são os fatos relevantes do caso?

- Existem fatos desconhecidos? Posso aprender mais sobre a situação? Eu sei o suficie nte para tomar uma decisão?

- Que indivíduos ou grupos têm uma participação importante no resultado?

- Quais são as opções de decisão? As pessoas ou grupos envolvidos foram consultados? Terceiro passo: avaliando ações alternativas

- Qual opção irá produzir o maior bem e trazer o menor dano? (Abordagem utilitarista)

- Qual opção respeita melhor os direitos de todos os envolvidos na situação? (Abordagem dos direitos)

- Qual opção trata as pessoas igualmente ou proporcionalmente? (Abordagem da justiça)

- Qual opção atende melhor a comunidade como um todo e não apenas algumas pessoas? (Abordagem do bem comum)

- Qual opção me leva a agir como o tipo de pessoa que eu quero ser? (Abordagem das virtudes éticas)

Quarto passo: tomando uma decisão

- Considerando todas essas abordagens, qual a opção que melhor aborda a situação?

- Se eu revelasse minha opção a alguém que eu respeito ou a exposse a um público de televisão ou jornal, o que diriam?

Quinto passo: agir e refletir sobre os resultados 
- Como pode a minha decisão ser implementada com o maior cuidado e atenção às preocupações de todas as partes interessadas?

- O que aprendi com a minha decisão e com essa situação específica?

Ressaltamos que essas questões não proporcionam uma solução automática para os problemas morais, nem que os estudantes irão abandonar suas crenças e valores iniciais, mas elas apenas permitem identificar e analisar algumas considerações morais importantes. Os princípios morais servem como uma referência por meio da qual podemos avaliar e direcionar nossas ações. Princípios morais são diferentes dos princípios científicos, que nos permitem uma avaliação rápida e decisiva em relação à determinadas questões. Esses são menos propensos a nos dar uma resposta correta, mas podem ser usados para avaliar situações conflitantes, um processo de tomada de decisão ou o resultado de uma decisão.

Do ponto de vista do ensino de Ciências, especificamente Biologia a identificação dos julgamentos morais por parte dos estudantes e de quais visões prevaleceram, nos ajudam a pensar as práticas de sala de aula, no sentido de problematizar e aprofundar melhor esses temas, por meio de discussões com QSC, que abarquem quadros éticos relacionados à biotecnologia e suas aplicações, além de aspectos relacionados à visão utilitarista da ciência, uma vez que, os estudantes trazem visões de certa forma ingênuas e não aprofundadas.

\subsubsection{Conhecimento científico, aspectos morais e QSC}

O conhecimento científico é importante para a análise das informações e a tomada de decisão em questões que requerem esse tipo de conhecimento, pois sem ele o estudante tende a apresentar uma resposta intuitiva, isto é, não reflexiva. Entretanto, nem todas as questões analisadas neste estudo requereram o conhecimento científico como base para o julgamento moral, como as relacionadas a clonagem reprodutiva e terapia gênica, nas quais os estudantes realizaram um julgamento moral com base na intuição sem realizarem uma análise reflexiva, considerando aspectos como os riscos e benefícios dessas aplicações biotecnológicas.

Nesse contexto, percebemos que a discussão de aspectos morais nem sempre necessita de conhecimentos científicos específicos. Isso significa que mesmo que o professor não tenha tempo para trabalhar todos os os conteúdos, ele deve buscar desenvolver estratégias que permitam inserir aspectos morais e valores nas aulas de Ciências.

Sugerimos ainda, que o professor possa atuar no desenvolvimento da metacognição moral. A metacognição é de importância significativa, principalmente no que diz respeito ao pensamento auto reflexivo e com a capacidade para o desenvolvimento de competências cada 
vez mais complexas e necessárias para a resolução de problemas sociomorais.

Para o trabalho com metacognição moral o modelo de tomada de decisão torna-se fundamental para que os estudantes possam levantar passo a passo os fatos relevantes, as pessoas envolvidas, os valores, as possíveis soluções, a decisão, a justificação e a apresentação dos resultados para a avaliação pelos pares, que pode ser em uma sessão de discussão, onde os estudantes possam expor os resultados de suas avaliações.

Os estudantes têm que perceber que estratégia em termos cognitivos estão utilizando para a tomada de decisão, como eles chegaram a determinado resultado, se foi por meio de uma avaliação que considerou os vários cenários que envolvem as QSC ou apenas a primeira resposta que veio à cabeça? Acreditamos que apenas a incorporação do quadro moral nas aulas não foi suficiente para o desenvolvimento do raciocínio moral dos estudantes, já que a partir da análise dos dados percebeu-se que para determinadas questões as crenças e até mesmo a existência de valores protegidos ou sagrados podem interferir no julgamento/tomada de decisão muitas vezes conduzindo a decisões baseadas em regras rígidas que ignoram os resultados.

Para Schrader (2003) pensar sobre o pensar envolve muitos tipos de processos cognitivos que podem ser utilizados na resolução de problemas mal estruturados. Os problemas morais, assim como as QSC são problemas mal estruturados o que conduz a ideia de que o trabalho com metacognição no domínio moral possa favorecer a compreensão de como essas questões possam ser resolvidas. Salienta-se que, formas complexas de metacognição envolvem uma coordenação de sistemas reflexivos de pensamento e o pensamento sobre relações sociais e ideais morais. Assim, o indivíduo passa a ser capaz não só de resolver problemas complexos com muitas variáveis, mas também pode conhecer os padrões e formular novas questões e soluções para situações e problemas que se repetem na vida das pessoas.

\subsubsection{Temas de QSC para discussão de aspectos morais e o currículo}

Quanto aos temas de QSC para a discussão de aspectos morais evidenciou-se que as aplicações da biotecnologia abordadas foram analisadas de formas diferentes em termos de moral por parte dos estudantes. Esse resultado aponta para a necessidade de desenvolver diversos cenários a fim de maximizar o entendimento, acerca da complexidade envolvida nesse assunto. Além de trabalhar com temas e QSC mais próximos da realidade dos estudantes, se possível sugeridos por eles.

Percebemos que o uso de quadros morais é um caminho eficaz para o favorecimento do raciocínio moral por meio de QSC, entretanto, identificou-se que as QSC que requerem 
respostas mais impessoais e que envolviam menos valores protegidos/sagrados, como os transgênicos tiveram uma inclusão maior do conhecimento científico e da reflexão pelo estudante para embasar suas justificativas.

O currículo tradicional representa um desafio para os professores e pesquisadores em termos da abordagem de QSC, uma vez que que necessita do desenvolvimento de propostas curriculares críticas que levem em consideração as questões ideológicas, políticas e culturais do ensino e da sociedade. Trabalhar com QSC implica no desenvolvimento de uma concepção crítica do currículo de Ciências, que deve começar com a consideração de que a ciência e a tecnologia são constructos socio, histórico e culturais que estão ligados à ideologias e interesses de diversos grupos sociais.

A escola constitui um espaço de reprodução social e cultural, onde a função social encontra-se ligada à ideologias e à práticas de dominação, sem dar maior importância as possibilidades de contestar essas ideologias e, dessa forma, desencadear processos de reconstrução curricular, que podem ser realizadas a partir das experiências dos docentes. Nesse contexto o trabalho com QSC surge como uma possibilidade de pensar transformações curriculares e docentes.

A partir do levantamento realizado nos documentos oficiais (Diretrizes Curriculares nacionais e BNCC) identificou-se que, embora haja o reconhecimento da necessidade do desenvolvimento da autonomia moral e intelectual, do letramento científico com vistas a formação para a cidadania, o currículo pretendido, por vezes chega a ser utópico, no que diz respeito à realidade das escolas do nosso país, e o currículo implementado continua em grande parte dominado pelo conteúdo. No entanto, para que qualquer mudança no currículo seja bemsucedida, essa deve ser acompanhada por uma reflexão quanto a prática pedagógica dos professores. Atualmente percebe-se que há pouca evidência dessa mudança, as escolas de EM ainda utilizam em sua maioria pedagogias transmissoras, ao lado de abordagens e contextos que não estabelecem relevância ou engajam os estudantes.

\subsubsection{Formação de professores}

Apesar do conhecimento por parte da professora pesquisadora sobre a natureza epistemológica da ciência, de amplo conhecimento científico relacionado aos temas abordados e quanto as teorias morais, a pouca experiência da mesma quanto a concepção, gestão e avaliação de atividades de discussão, em geral, e de QSC dificultaram o desenvolvimento deste estudo, além de corroborar com o que os outros estudos revelaram sobre a importância do 
professor na implementação das QSC. Dadas as ênfases tanto sobre o desenvolvimento cognitivo quanto do raciocínio moral dos estudantes e da magnitude e complexidade das QSC, considerou-se que o professor precisa desenvolver competência no uso de estratégias de ensino e recursos tais como quadros morais e processos dialógicos e reflexivos para facilitar o desenvolvimento do raciocínio sociocientífico e moral dos estudantes, já que esses aspectos podem constituir limitações para o desenvolvimento de uma abordagem com QSC em sala de aula.

Neste estudo, percebeu-se que não basta que os professores possuam uma visão filosófica e sociologicamente mais rica e reflexiva sobre a ciência e suas interações com a tecnologia, a sociedade e o ambiente, pois as relações entre essas concepções e a prática de sala de aula é mediada por um conjunto diversificado e complexo de fatores. Assim, faz-se necessária a compreensão e a elaboração de estratégias que possam transpor essas limitações.

A promoção de currículos que integrem as QSC exige tempo e alguns recursos e materiais de apoio para serem utilizados em sala de aula, programas de formação de professores e formação inicial que promovam conexões entre a moral e a ciência.

Não podemos deixar de apontar a importância da definição pelo professor dos objetivos do ensino de Ciências e a partir daí seu papel na construção do currículo. Entretanto, muitos professores, assim como a professora pesquisadora, não se sentem preparados para essa escolha, apresentando dificuldade para escolher determinados conteúdos em detrimento de outros, normalmente isso já tem que ser feito, pois a carga horária da disciplina Biologia não é suficiente para abordar todos os conteúdos previstos no currículo oficial.

Outro aspecto que pesa na escolha dos conteúdos é a preparação dos estudantes para o ENEM e vestibulares, ainda existe uma forte cultura no EM de preparação para o vestibular, assim quando não se aborda determinado conteúdo fica-se com a impressão de estar tirando a oportunidade do estudante da escola pública, uma vez que as escolas particulares têm como prioridade essa preparação. Ainda, podemos elencar outros fatores como o tempo para o planejamento das atividades por parte do professor, a grande quantidade de turmas (em média 15 para o professor de Biologia, 30 horas em sala de aula e 10 para coordenação) e o grande número de estudantes por turma (em média 38 a 42) que o que tem dificultado a realização de alguns tipos de atividades.

Este estudo demonstrou que não se trabalha QSC e moral só com a inserção do conhecimento científico e a inclusão de um quadro moral, mas com discussões, debates, atividades que oportunizem aos estudantes exporem e confrontarem suas opiniões. 


\section{CONSIDERAÇÕES FINAIS}

Ao iniciar esta pesquisa tinha-se como principal objetivo desenvolver sequências didáticas com a introdução de QSC relativas a dilemas de biotecnologia que envolvem aspectos morais, a fim de caracterizar implicações pedagógicas para tratar questões morais no ensino de Biologia. Nas questões deste estudo evidenciou-se a necessidade de um melhor entendimento sobre QSC e moral, portanto indagou-se: Que aspectos morais orientam a tomada de decisão dos estudantes em relação à QSC de biotecnologia? Qual a relação entre os conhecimentos científicos específicos de Biologia e o raciocínio moral dos estudantes na tomada de decisão de QSC de biotecnologia? Que desafios pedagógicos são enfrentados na introdução de QSC, com o propósito de tratar de questões morais no ensino de Biologia? Qual o papel da abordagem de QSC em sala de aula no favorecimento do raciocínio moral dos estudantes?

Para responder a essas questões de pesquisa elaborou-se uma apresentação das diferentes ideias e concepções de vários autores sobre o letramento científico, o movimento CTS e as QSC, apresentando seus significados, suas origens e seus objetivos. Indicamos que o letramento científico, o movimento CTS e QSC apesar das diferentes ideias, possuem um determinado nível de convergência quanto à necessidade da inserção dos aspectos sociais, econômicos, políticos, culturais e morais que envolvem a ciência e a tecnologia no ensino de Ciências.

A compreensão da importância de estudos sobre QSC e moral levou a elaborar uma revisão da literatura que permitisse um mapeamento dos estudos sobre esse tema. Concluiu-se que já existe um grande número de artigos da área que mencionam a relevância das aulas de Ciências para a formação moral ou, ainda, para a formação integral do estudante, denotando uma preocupação que vai além dos conteúdos específicos das disciplinas. Dos diversos artigos sobre QSC apenas um percentual muito pequeno está relacionado ao estudo de QSC e moral, revelando uma lacuna.

No que se refere aos aspectos morais, éticos e valores, na análise dos documentos oficiais da educação, DCNEM e BNCC, observou-se que essa temática comparece nos dois documentos em questão. Percebeu-se a incorporação da ética, moral e valores visando conciliar humanismo e tecnologia, exercício de cidadania e conhecimento acerca da ciência e tecnologia, 
formação ética e autonomia intelectual e moral, uma formação comprometida com o pleno desenvolvimento dos indivíduos.

Conclui-se que os estudantes interpretaram questões sobre aplicações da biotecnologia com base em considerações relativas ao domínio moral, fundamentadas em três tipos de julgamentos: deontológico, utilitarista e ceticismo moral. Em relação aos transgênicos a categoria que apareceu com mais frequência foi a moral utilitarista. Entretanto, quando as aplicações da biotecnologia tinham fins terapêuticos (clonagem e terapia gênica) tiveram a aprovação da maioria dos estudantes, sendo consideradas moralmente aceitáveis e legítimas, uma vez que, pretendem melhorar a qualidade de vida de indivíduos e populações humanas. Nesses casos, a categoria que compareceu com maior frequência foi a moral deontológica.

Nesse contexto, observou-se que as aplicações da biotecnologia abordadas foram analisadas de formas diferentes em termos da moral por parte dos estudantes, e que fatores como o contexto, as emoções e a existência de valores protegidos e sagrados podem ter influenciado o julgamento moral. Esse resultado corrobora com o quadro de flexibilidade moral e nos direciona para a necessidade de desenvolver diversos cenários a fim de maximizar o entendimento, acerca da complexidade envolvida nesse assunto.

A percepção dos estudantes em relação ao uso/aceitação da tecnologia foi modificada no questionário e na QSC salmão transgênico. Essa mudança foi percebida por meio dos testes de hipóteses realizados. Em relação à categoria consciência ecológica nas questões sobre transgênicos, os testes de hipótese, também indicaram mudança na percepção quanto à categoria em questão em todos os instrumentos. Quanto à clonagem reprodutiva, a oficina alterou a opinião dos estudantes quanto a serem contrários à essa tecnologia.

No que diz respeito às considerações relativas ao domínio moral em relação aos transgênicos e à clonagem reprodutiva, os testes de hipóteses indicaram que não houve mudanças na percepção dos estudantes. Em relação às considerações do domínio moral, realizando os mesmos testes de hipóteses, foi possível obter resultados que permitem dizer que não houve mudança nas considerações do domínio moral dos estudantes. Para clonagem reprodutiva, a oficina alterou a opinião dos estudantes quanto a serem contrários a esse tipo de procedimento. Em relação à terapia gênica, os resultados demonstraram não haver evidências suficientes para afirmar que a oficina mudou a opinião dos estudantes ou suas considerações morais. Somente no caso do teste questionário x QSC albinismo questão 2 a hipótese nula foi rejeitada, ou seja, a oficina modificou a opinião dos estudantes quanto a serem contrários ou favoráveis. 
Diante desses resultados, percebeu-se que com a realização da SD houve mudanças nas percepções dos estudantes quanto as categorias contrário e favorável, risco, consciência ecológica, mas que, entretanto, quando se tratava dos discursos do domínio moral dos estudantes identificou-se que esses não foram modificados após a realização da oficina.

Quanto ao conhecimento científico, percebeu-se que em relação aos transgênicos houve a incorporação dos conhecimentos para justificar o julgamento dos estudantes. Entretanto, o mesmo não aconteceu com as outras QSC, como clonagem e terapia gênica. Assim, identificou-se que o contexto da QSC determina o tipo de abordagem a ser utilizada pelo estudante. Uma abordagem em que o estudante não utiliza o conhecimento ensinado para a justificação da decisão tem uma maior ocorrência em decisões mais individualistas e pessoais, resultando em um raciocínio que envolve mais a emoção e a intuição.

Ainda assim, sugerimos a inclusão desses temas no EM, pois compreendemos que discussões envolvendo temas da biotecnologia podem contribuir para o desenvolvimento de pontos de vista mais complexos e críticos, consistentes com a utilização de argumentos que sejam mais razoáveis e imparciais.

Isso, de certa forma, parece indicar que discussões de QSC sobre biotecnologia não se esclarecem apenas pela ciência, e sim por diversos outros fatores, o que implica que a participação dos estudantes em QSC depende da natureza da QSC e dos valores a que estiverem relacionados.

Considerou-se que o uso de quadros morais é um meio eficaz para o desenvolvimento do raciocínio moral, principalmente nas que requerem respostas mais impessoais e em que o conhecimento científico for mais solicitado pelo estudante para embasar suas justificativas. Entretanto, sugerimos a necessidade de inclusão de um modelo de tomada de decisão para uma melhor avaliação do contexto e dos envolvidos em cada cenário, além dos valores implícitos nas questões. O modelo de tomada de decisão pode ser uma ferramenta útil para o desenvolvimento da metacognição moral, especialmente nos casos em as decisões são mais pessoais e envolvem a existência de crenças, valores protegidos e sagrados.

A utilização de quadros morais também estabeleceu a importância de incorporar valores na educação científica com vistas a formação para a cidadania responsável, com estudantes capazes de elaborarem julgamentos e tomarem decisões em situações cotidianas que envolvem a ciência. A incorporação de princípios morais pode ser a chave na determinação de como se julga o que é moralmente certo. A presente pesquisa indicou que existem diferentes princípios morais utilizados pelos estudantes na elaboração de julgamentos morais. 
Neste estudo, considerou-se que o número reduzido de aulas, a realização de poucas atividades que envolvessem uma maior participação e construção do conhecimento, a complexidade própria do lidar com QSC, tanto na formulação de questionamentos, quanto em explorar o discurso no sentido de provocar uma situação argumentativa e desenvolvê-la, e o envolvimento limitado dos estudantes nas atividades da parte diversificada do currículo, constituíram-se em aspectos limitantes da implementação dessa proposta pedagógica em sala de aula.

Ainda, destacou-se que não basta que os professores possuam uma visão filosófica e sociologicamente mais rica e reflexiva sobre a ciência e suas interações com a tecnologia, a sociedade e o ambiente, pois as relações entre essas concepções e a prática de sala de aula é mediada por um conjunto diversificado e complexo de fatores. Dada a importância do professor nesse processo, apontou-se a necessidade de inclusão de QSC e moral na sua formação inicial, pois atualmente os futuros professores saem despreparados para a atuação frete ao raciocínio moral e sociocientífico.

A promoção de currículos que integrem as QSC também exige tempo e alguns recursos como materiais de apoio para serem utilizados em sala de aula, programas de formação de professores e formação inicial que promovam conexões entre a moral e a ciência.

Defendeu-se como tese que a introdução de aspectos morais em QSC é essencial no ensino de Biologia para preparar os estudantes para a tomada de decisão moral, sendo que, para isso ocorrer no contexto curricular da maioria das escolas brasileiras, muitos desafios precisam ser enfrentados como: a) a formação de professores, tanto a inicial como a continuada, com vistas ao desenvolvimento de competências para o uso de estratégias de ensino diversificadas; b) a aplicação de quadros morais e processos dialógicos e reflexivos para facilitar o desenvolvimento do raciocínio sociocientífico e moral dos estudantes, haja vista que tais aspectos podem constituir limitações para o desenvolvimento de uma abordagem com QSC em sala de aula; c)o enfrentamento de questões como certas imposições curriculares, a falta de recursos e a pouca quantidade de aulas, que acabam exigindo muita criatividade por parte dos professores que optam por um trabalho como esse.

A partir deste estudo, conclui-se que só o conhecimento científico e o quadro moral não foram suficientes para trabalhar QSC e moral, pois são necessárias oportunidades para os estudantes exporem e confrontarem suas opiniões. Devido à complexidade do fenômeno moral, as variáveis emergentes nesse estudo podem não ter sido suficientemente abrangentes para 
representá-lo. Assim, são necessários mais estudos nessa área com vistas ao fechamento das lacunas existentes. 



\section{REFERÊNCIAS}

ACEVEDO DÍAZ, J. A.; VASQUÉZ ALONSO, A.; MANASSERO MAS, M. A. Papel de la educación CTS en una alfabetización científica y tecnológica para todas las personas, Revista Electrónica de Enseñanza de las Ciencias, v. 2, n. 2, p. 80-111, 2003.

AGIN, M. L. Education for scientific literacy: A conceptual frame of reference and some applications. Science Education, v. 58, n. 3, p.403-415, 1974.

AIKENHEAD, G. S. STS Education: a rose by any other name. In: CROSS, R. (Ed.). A Vision for Science Education: Responding to the Work of Peter Fensham. Routledge Falmer, 2003. p. 59-75.

AIKENHEAD, G. S. The humanistic and cultural aspects of science \& technology education. A plenary paper presented to the 11th International Organization for Science and Technology Education (IOSTE) Symposium Lublin, Poland, 2004. p. 25-30.

AIKENHEAD, G. What is STS? In: SOLOMON, J., AIKENHEAD, G. STS education: international perspectives on reform. New York: Teachers College Press, 1994. p. 47-59.

AULER, D. Enfoque ciência-tecnologia-sociedade: pressupostos para o contexto brasileiro. Ciência \& Ensino, v. 1, número especial, nov. 2007.

AULER, D.; DELIZOICOV, D. Alfabetização científico-tecnológica para quê? Ensaio, v. 3, n. 2, p. 105-115, 2001.

BAKER, D. R. A summary of research in science education - 1989. Scientific literacy.

Science Education, v. 75, n. 3, p. 330-333, 1991.

BARGH, J. The four horsemen of automaticity: Awareness, efficiency, intention, and control in social cognition. In: WYER, J. R. S.; SRULL, T. K. (Eds.), Handbook of social cognition, 2nd edition (p. 1-40). Hillsdale, NJ: Erlbaum, 1994.

BARON, J. Thinking and deciding. 4. ed. Cambridge University Press, 2008.

BARON, J.; SPRANCA, M. Protected values. Organizational Behavior and Human Decision Processes, v. 70, n. 1, p. 1-16, 1997.

BARRETT, S. E.; NIESWANDT, M. Teaching about ethics through socioscientific issues in physics and chemistry: teacher candidates' beliefs. Journal of Research in Science Teaching, v. 47, n. 4, p. 1-22, 2010.

BARTELS, D. M.; BAUMAN, C. W.; CUSHMAN, F. A.; PIZARRO, D. A.; MCGRAW, A. P. "Moral judgment and decision making," In: KEREN, G.; WU, G. (Eds.). Judgment and decision making. Malden, MA: Blackwell, 2014.

BASTICK, T. Intuition: How we think and act. Chichester, England: Wiley, 1982.

BAZZO, W. A; COLOMBO, C. R. Educação tecnológica contextualizada: ferramenta essencial para o desenvolvimento social brasileiro. Revista de Ensino de Engenharia, Florianópolis, v. 20, n. 1, p. 9-16, 2001.

BELL, R. L.; LEDERMAN, N. G. Understandings of the nature of science and decision making on science and technology based issues. Science Education, v. 87, n. 3, p. 352-377, 2003. 
BENTHAN, J. An introduction to the principles of morals and legislation. Batoche Books Kitchener, 2000.

BERKOWITZ, M. W.; SIMMONS, P. Integrating science education and character education: The role of peer discussion. In: ZEIDLER, D. L. (Ed.). The role of moral reasoning on socioscientific issues and discourse in science education. Dordrecht: Kluwer Academic Press, 2003. p. 117-138.

BRANDI, A. T. E.; GURGEL, C. M. A. A alfabetização científica e o processo de ler e escrever em séries iniciais: emergências de um estudo de investigação-ação. Ciência \& Educação, v. 8, n. 1, p.113-125, 2002.

BRASIL. Lei de Diretrizes e Bases da Educação. Lei n ${ }^{\circ}$ 9.394/96, de 20 de dezembro de 1996.

BRASIL. Ministério da Educação, Secretaria de Educação Básica. Documento de apresentação da Base Curricular Comum Nacional - BNCC. Brasilia, 2015. Disponível em: <http://basenacionalcomum.mec.gov.br/\#/site/inicio〉. Acesso em: 13 fev. 2015.

BRASIL. Ministério da Educação, Secretaria de Educação Básica. Secretaria de Educação Continuada, Alfabetização, Diversidade e Inclusão. Secretaria de Educação Profissional e Tecnológica. Conselho Nacional da Educação. Câmara Nacional de Educação Básica.

Diretrizes Curriculares Nacionais Gerais da Educação Básica. Brasîlia:

MEC/SEB/DICEI, 2013.

BRYAN, L. A.; ATWATER, M. M. Teacher beliefs and cultural models: A challenge or science teacher preparation programs. Science Education, v. 86, n. 6, p. 821-839, 2002.

BRYCE, T.; GRAY, D. Tough acts to follow: The challenges to science teachers.

International Journal of Science Education, v. 26, n. 6, p. 717-733, 2004.

BUSSAB, W. O.; MORETTIN, P. A. Estatística básica. 7. ed. São Paulo: Saraiva, 2012. $542 \mathrm{p}$.

BYBEE, R.W. Achieving scientific literacy: From purposes to practices. Portsmouth, NH: Heinemann, 1997.

CALLADO MORENO, J. A. Relación entre el nível de desarrollo del juicio moral del professorado de tercer ciclo de educación primaria y su disposición a la transmisión de valores sociales a su alunado. Tese (Doutorado em Educação) - Departamento de Pedagogia da Faculdade de Humanidades y Ciencias de la Educación. Jaén: Universidad de Jaén, 2012. $850 \mathrm{p}$.

CANTO-SPERBER, M. A inquietude moral e a vida humana. São Paulo: Loyola, 2005.

CARVALHO, A. M. P.; TINOCO, S. C. O ensino de ciências como enculturação. In: CATANI, B. D.; VICENTINI, P. P. (Orgs.). Formação e Autoformação: saberes e práticas nas experiências dos professores. São Paulo: Escrituras, 2006. p. 251-255

CASTILHO, M. Kant, Immanuel, 1724-1804. Tradução Magda Lopes. In: CANTOSPERBER, M. (Org.). Dicionário de ética e filosofia moral. Tradução Ana Maria RibeiroAlthoff et al. São Leopoldo, RS: Editora Unisinos, 2013. p. 584-588.

CORTINA, A.; MARTíNEZ, E. Ética. Tradução: Silvana Cobucci Leite. Resumo Prof. Dr. Roque Junges. São Paulo: Ed. Loyola, 2005. 
ČRNE-HLADNIK, H.; HLADNIK, A.; JAVORNIK, B.; KOŠMELJ, K.; PEKLAJ, C. Is judgement of biotechnological ethical aspects related to high school students' knowledge? International Journal of Science Education, v. 34, n. 8, p. 1277-1296, 2012.

CROSS, R. T.; PRICE, R. F. Science teachers' social conscience and the role of controversial issues in the teaching of science. Journal of Research in Science Teaching, v. 33, n. 3, p. 319-333, 1996.

CHASSOT, A. Alfabetização científica: Questões e desafios para a educação, Ijuí, Editora da Unijuí, 2000.

CHASSOT, A. Alfabetização científica: uma possibilidade para a inclusão social. Revista Brasileira de Educação, n. 22, p. 89-100, 2003.

DAWSON, V.; SCHIBECI, R. Western Australian school students' understanding of biotechnology. International Journal of Science Education, 25, 57-69, 2003.

DEBOER, G. E. A history of ideas in science education. New York: Teachers College Press, 1991.

DEBOER, G. E. Scientific literacy: Another look at its historical and contemporary meanings and its relationship to science education reform. Journal of Research in Science Teaching, v. 37, n. 6 , p. $582-601,2000$.

DRIVER, J. The history of utilitarianism. In: ZALTA, E. N. (Ed.). The Stanford Encyclopedia of Philosophy, 2014. Disponível em: <http://plato.stanford.edu/archives/win2014/entries/utilitarianism-history/>. Acesso em: 15 maio 2015.

DRIVER, R., NEWTON, P.; OSBORNE, J. Establishing the norms of scientific argumentation in classrooms. Science Education, v. 84, n. 3, p. 287-312, 2000.

DURBANO, J. P. M.; PADILHA, I. Q. M.; RÊGO, T. G.; RODRIGUES, P. A. L.; ARAÚJO, D.A.M. Percepção do conhecimento dos alunos de ensino médio do município de João Pessoa-PB sobre temas emergentes em biotecnologia. In: CONGRESSO BRASILEIRO DE GENÉTICA, 54, 2008, Salvador. $5^{\mathbf{0}}$ Congresso B rasileiro de Genética. Salvador: SBG, 2008, p. 4. Disponível em: <http//web2.sbg.org.br/congress/sbg2008/resumos_index.asp\#>. Acesso em: 11 jan. 2016.

ESPÍRITO SANTO, M. L. F. O princípio supremo da moralidade na Fundamentação Metafísica dos Costumes de Kant. 2007. 120f. Dissertação (Mestrado em Filosofia) Instituto de Filosofia e Ciências Humanas, Universidade do Rio Grande do Sul, Porto Alegre, RS, 2007.

FENSHAM, P.J. Approaches to the teaching of STS in science education. International Journal of Science Education, v. 10, n. 4, p. 346-356, 1988.

FERRER, J. J.; ÁLVAREZ, J. C. Para fundamentar a bioética: Teorias e paradigmas teóricos na bioética contemporânea. São Paulo: Loyola, 2005.

FINUCANE, M. L.; ALHAKAMI, A.; SLOVIC, P.; JOHNSON, S. M. The affect heuristic in judgments of risks and benefits. Journal of Behavioral Decision Making, v. 13, p. 1-17, Jan/Mar 2000.

FOWLER, S. R.; ZEIDLER, D. L.; SADLER, T. D. Moral sensitivity in the context of socioscientific issues in high school science students. International Journal of Science Education, v. 31, n. 2, p. 279-296, 2009. 
FRADE, C.; GAMEIRO, I. Regulação do risco e participação: o caso dos organismos geneticamente modificados. e-cademos ces [Online], 02/2008. Disponível em: <http//eces.revues.org/1460>. Acesso em: 30 abril 2016.

GABEL, L. L. The development of a model to determine perceptions of scientific literacy. Unpublished doctoral thesis, The Ohio State University, Columbus, OH, 1976.

GAJARDO, M. Pesquisa participante na América Latina. São Paulo: Brasiliense, 1986.

GARDNER, G. E. Biotechnology risks and benefits: Science instructor perspectives and practices. ProQuest, 2009.

GARFIELD, E. Science literacy. Part 2. Major research areas and recommendations for the future. Current Contents, v. 32, n. 20, p. 3-11, 1988.

GARVEY, J. Mudanças climáticas: considerações éticas o certo e o errado no aquecimento global. Tradução: Rogério Bettoni. São Paulo: Rosari, 2010. 144p.

GEDDIS, A. N. Improving the quality of science classroom discourse on controversial issues. Science Education, v. 75, n. 2, p. 169-183, 1991.

GOLDFARB, T. D.; PRITCHARD, M. S. Ethics in the science classroom: An instructional guide for secondary school science teachers with model lessons for classroom use, 2000. Disponível em: <www.wmich.edu/ethics/ESC/index.html>. Acesso em: 20 nov. 2015. GONTIJO, E. D. Os termos 'Ética' e 'Moral'. Mental, a. IV, n. 7, p. 127-135, 2006. GONZÁLEZ REY, F. L. Motivación moral en adolescentes y jóvenes. La Habana: Científico-Técnica, 1983.

GONZÁLEZ REY, F. L.; MITJÁNS MARTÍNEZ, A. La personalidade, su educación y desarrolho. La Habana: Pueblo y Educación, 1989

GRACE, M. M.; RATCLIFFE, M. The science and values that young people draw upon to make decisions about biological conservation issues. International Journal of Science Education, v. 24, n. 11, p. 1157-1169, 2002.

GREENE, J. D. Why are VMPFC patients more utilitarian? A dual-process theory of moral judgment explains. Trends in Cognitive Sciences, v. 11, n. 8, p. 322-323, 2007.

GREENE, J. D.; SOMMERVILLE, B.; NYSTROM, L. E.; DARLEY, J. M.; COHEN, J. D. An fMRI investigation of emotional engagement in moral judgment. Science, v. 293, p20152108, 2001.

GREENE, J.; HAIDT, J. How (and where) does moral judgment work? Trends in Cognitive Sciences, v. 6, n. 12, p. 517-523, 2002.

GRIER, L. K.; FIRESTONE, I. J. The effects of an intervention to advance moral reasoning and efficacy. Child Study Journal, v. 28, n. 4, p. 267-290, 1998

GUIMARÃES, M. A.; CARVALHO, W. L. P.; OLIVEIRA, M. S. Raciocínio moral na tomada de decisões em relação a questões sociocientíficas: O exemplo do melhoramento genético humano. Ciência \& Educação, v. 16, n. 2, p. 465-477, 2010.

HAIDT, J. The emotional dog and its rational tail: A social intuitionist approach to moral judgment. Psychological Review, v. 108, p. 814-834, 2001.

HAIDT, J.; KOLLER, S. H.; DIAS, M. G. Affect, culture, and morality, or is it wrong to eat your dog? Journal of Personality and Social Psychology, v. 65, p. 613-628, 1993. 
HANEY, J. J.; CZERNIAK, C. M.; LUMPE, A. T. Teacher beliefs and intentions regarding the implementation of science education reform strands. Journal of Research in Science Teaching, v. 33, n. 9, p. 971-993, 1996.

HODSON, D. Going Beyond STS: Towards a curriculum for sociopolitical action. The Science Education Review, v. 3, n. 1, p. 2-7, 2004.

HOTTOIS, G. História da Filosofia: da Renascença à Pós-modernidade. Lisboa: Instituto Piaget. 2003.

HOTTOIS, G. Qual é o quadro temporal para pensar nas gerações futuras? Uma abordagem filosófica. In: SCHRAMM, F. R. et al. (Org.) Bioética, risco e proteção. Rio de Janeiro: Ed. UFRJ/FIOCRUZ, p. 101-132, 2009.

HURD, P.D. Science literacy: It's meaning for American schools. Educational Leadership, v. 16, n. 1, p. $13-16,1958$.

HURD, P.D. Scientific literacy: New minds for a changing world, Science Education, v. 82, n. 3, p. 407-416, 1998.

HURSTHOUSE, R. Virtue Ethics. In: ZALTA, E. N (Ed.). The Stanford Encyclopedia of Philosophy, 2013. Disponível em: <http://plato.stanford.edu/archives/fall2013/entries/ethicsvirtue/>. Acesso em: 25 fev. 2015.

IBOPE. Pesquisa de opinião pública sobre transgênicos. 2001. Disponível em: $<\mathrm{http} / /$ www.greenpeace.com.br/transgenicos/pdf/pesquisaIBOPE_agosto2001.pdf>. Acesso em: 15 abril 2016.

IBOPE. Pesquisa de opinião pública sobre transgênicos. 2002. Disponível em: $<$ http://www.ibope.com.br/ptbr/conhecimento/relatoriospesquisas/Lists/RelatoriosPesquisaEleitoral/OPP\%2057302\%20\%20Idec\%20-\%20Alimentos\%20trans genicos.pdf>. Acesso em: 15 abril 2016.

IBOPE. Pesquisa de opinião pública sobre transgênicos. 2003. Disponível em: < http://www.greenpeace.org/brasil/Global/brasil/report/2007/8/greenpeacebr_031230_transgen icos_pesquisa_ibope_2003_port_v1.pdf>. Acesso em: 15 abril 2016.

JALLINOJA, P.; ARO, A. R. Does knowledge make a difference? The association between knowledge about genes and attitudes toward gene tests. Journal of Health Communication, v. 5, n. 1, p. 29-39, 2000.

JIMÉNEZ-ALEIXANDRE, M. P., RODRÍGUEZ, A. B.; DUSCHL, R. A. "Doing the lesson" or "doing science": Argument in high school genetics. Science Education, v. 84, n. 6, p. 757$792,2000$.

JIMÉNEZ-ALEIXANDRE，M. P.; PEREIRO-MUNHOZ, C. Knowledge producers or knowledge consumers? Argumentation and decision making about environmental management. International Journal of Science Education, v. 24, n. 10, p. 1171-1190, 2002.

JONES, A.; MCKIM, A.; REISS, M.; RYAN, B.; BUNTTING, C.; SAUNDERS, K. Research and development of classroom-based resources for bioethics education in New Zealand. Hamilton, NZ: Wilf Malcolm Institute of Educational Research, School of Education, University of Waikato, 2007.

KANT, I. Fundamentação metafísica dos costumes. Tradução: Leopoldo Rolzbach. São Paulo: Martins Claret, 2002. 
KHISHFE, R.; LEDERMAN, N. G. Teaching nature of science within a controversial topic: Integrated versus nonintegrated. Journal of Research in Science Teaching, v. 43, n. 4, p. 395-418, 2006.

KOLST Ø, S. D. 'To trust or not to trust,... '-pupils' ways of judging information encountered in a socio-scientific issue. International Journal of Science Education, v. 23, n. 9, p. 877901, 2001b.

KOLSTØ, S. D. Patterns in students' argumentation confronted with a risk-focused socioscientific issue. International Journal of Science Education, v. 28, n.14, p. 1689-1716, 2006.

KOLSTØ, S. D. Scientific literacy for citizenship: Tools for dealing with the science dimension of controversial socioscientific issues. Science Education, v. 85, n. 3, p. 291-310, 2001a.

KORPAN, C. A.; BISANZ, G. L.; BISANZ, J.; HENDERSON, J. M. Assessing literacy in science: Evaluation of scientific news briefs. Science Education, v. 81, p. 515-532, 1997.

KORTLAND, K. An STS case study about students' decision making on the waste issue. Science Education, v. 80, n. 6, p. 673-689, 1996.

KOTTOW, M. Introducción a la bioética. Santiago: Editorial Universitária, 1995. 172p.

KUHN, D. Science as argument: Implications for teaching and learning scientific thinking. Science Education, v. 77, n. 3, p. 319-337, 1993.

KUHN, T. S. A estrutura das revoluções científicas. São Paulo: Perspectiva, 1991.

LACEY, H. OGMs: A estrutura da controvérsia. Comciência, n. 31, 2002. Disponível em: http://www.comciencia.br/reportagens/framereport.htm. Acesso em: 21 jan. 2016.

LACEY, H. Valores e Atividade Científica 1. São Paulo: Associação Filosófica 'Scientiae Studia'/Editora 34, 2008.

LAYTON, D., JENKINS, E.; DONNELLY, J. Scientific and technological literacy: Meanings and rationales, an annotated bibliography. Leeds, UK: Centre for Studies in Science and Mathematics Education, University of Leeds, 1994.

LE BOTERF, G. Pesquisa participante: Propostas e reflexões metodológicas. In: BRANDÃO, C. R. (Org.). Repensando a pesquisa participante. 3 ed. São Paulo: Brasiliense, 1987. p. 51 81.

LEDERMAN, N. Improving students' conceptions of the nature of science: The role and influence of the classroom teacher. In: LAWRENZ, F.; COCHRAN, K.; KRAJCK, J. e SIMPSON, P. (Eds.). Research matters... to the science teacher (Vol. NARST Monograph 5, pp. 11-19). Manhattan, KS: Science Education Center. 1992. p. 11-19.

LEE, H.; CHANG, H.; CHOI, K.; KIM, S. W.; ZEIDLER, D. L. Developing character and values for global citizens: Analysis of pre-service science teachers' moral reasoning on socioscientific issues. International Journal of Science Education, v. 34, n. 6, p. 925-953, $2012 \mathrm{a}$.

LEE, H.; YOO, J.; CHOI, K.; KIM, S. W.; KRAJCIK, J; HERMAN, B. C.; ZEIDLER, D. L. Socioscientific issues as a vehicle for promoting character and values for global citizens. International Journal of Science Education, v. 35, n. 12, p. 2079- 2113, 2012 b.

LEVINSON, R. Towards a theoretical framework for teaching controversial socio-scientific issues. International Journal of Science Education, v. 28, n. 10, p. 1201-1224, 2006. 
LINDAHL, M. G. Ethics or morals: Understanding students' values related to genetic tests on humans. Science \& Education, v. 18, n. 10, p. 1285-1311, 2009.

LORENZETTI, L.; DELIZOICOV, D. Alfabetização científica no contexto das séries iniciais. Ensaio - Pesquisa em Educação em Ciências, v. 3, n. 1, p. 37-50, 2001.

LOVING, C. C.; FOSTER, A. The religion in the science classroom issue: Seeking graduate student conceptual change. Science Education, v. 84, n. 4, p. 445-468, 2000.

MAMEDE, M.; ZIMMERMANN, E. Letramento científico e CTS na formação de professores para o ensino de física. In: SIMPÓSIO NACIONAL DE ENSINO DE FÍSICA, 16, 2005, Rio de Janeiro. Anais. Disponível em: $\langle$ http $/ /$ www.sbf1.sbfisica.org.br/eventos/snef/xvi/cd/resumos/T0264-1.pdf $>$. Acesso em: 06 nov. 2013.

MASSARANI, L.; MOREIRA, I. C. Os transgênicos rondam a sua cozinha. Com Ciencia, n. 31, 2002. Disponível em: http://www.comciencia.br/reportagens/trans genicos/trans19.htm.

Acesso em: 10 maio 2016

MILL, J. S. Utilitarianism. Ontário: Batoche Books Kitchener, 2001.

MOON, W.; BALASUBRAMANIAN, S. K. Public attitudes toward agrobiotechnology: The mediating role of risk perceptions on the impact of trust, awareness, and outrage. review of agricultural economics, v. 26, p. 186-208, 2004.

MORAES, R.; GALIAZZI, M. C. Análise textual discursiva. Ijuí: Ed. Unijuí, 2007.

MORTIMER, E. F.; MACHADO, A. M. A linguagem numa sala de aula de ciências. Presença Pedagógica. Belo Horizonte, Dimensão, v. 2, n. 11, p. 49-57, 1996.

MUELLER, M. P.; ZEIDLER, D. L. Moral-ethical character and science education: Ecojustice ethics through socioscientific issues (SSI). In: TIPPINS, M. D.; MUELLER, M.; VAN EIJCK; ADAMS, J. (Eds.). Cultural studies and environmentalism: The confluence of ecojustice, place-based (science) education, and indigenous knowledge systems. New York: Springer. 2010. p. 105-128.

NIELSEN, J. A. Co-Opting Science: A Preliminary Study of How Students Invoke Science in Value-Laden Discussions. International Journal of Science Education, v. 34, n. 2, p. 275$299,2012$.

NUCCI, L. Psicologia moral e educação: para além de crianças "boazinhas". Educação e Pesquisa, São Paulo, v.26, n.2, p. 71-89, 2000.

NUCCI, L.; CAMINO, C.; SAPIRO, C. Social class effects on Northeastern Brazilian children's conceptions of areas of personal choice and social regulation. Child Development, v. $67,1223-1242,1996$.

OSBORNE, J., ERDURAN, S.; SIMON, S. Enhancing the quality of argument in school science. Journal of Research in Science Teaching, v. 41, n. 10, p. 994-1020, 2004.

OULTON, C., DILLON, J.; GRACE, M. Reconceptualising the teaching of controversial issues. International Journal of Science Education, v. 26, n. 4, p. 411-423, 2004.

PATRONIS, T.; POTARI, D.; SPILIOTOPOULOU, V. Students' argumentation in decisionmaking on a socio-scientific issue: Implications for teaching. International Journal of Science Education, v. 21, n. 7, p. 745-754, 1999.

PAXTON, J. M.; GREENE, J. D. Moral reasoning: Hints and allegations. Topics in Cognitive Science, v. 2, n. 3, p. 511-527, 2010. 
PEDRANCINI, V. D.; CORAZZA-NUNES, M. J.; GALUCH, M. T. B.; MOREIRA, A. L. O. R.; NUNES, W. M. C. Saber científico e conhecimento espontâneo: Opiniões de alunos do ensino médio sobre transgênico. Ciência \& Educação, Bauru, v. 14, n. 1, p.135-146, 2008.

PEDRETTI, E. Septic tank crisis: a case study of science, technology and society education in an elementary school. International Journal of Science Education, v. 19, n. 10, p. 12111230, 1997.

PEDRETTI, E. Teaching science, technology, society and environment (STSE) education: Preservice teachers' philosophical and pedagogical landscapes. In: ZEIDLER, D. L. (Org). The role of moral reasoning on socioscientific issues and discourse in science education. Netherlands: Kluwer Academic Publishers, 2003. p. 219-239.

PEDRETTI, E.; BENCZE, L.; HEWITT, J.; ROMKEY, L.; JIVRAJ, A. Promoting issues based STSE: Perspectives in science teacher education: problems of identity and ideology. Science \& Education, v. 17, n. 8-9, p. 941-960, 2008.

PEDRETTI, E.; HODSON, D. From rhetoric to action: Implementing STS education through action research. Journal of Research in Science Teaching, v. 32, n.5, p. 463-485, 1995.

PEDRO, A. P. Ética, moral, axiologia e valores: confusões e ambiguidades em torno de um conceito comum. Kriterion, Belo Horizonte, n. 130, p. 483-498, 2014.

PELLA, M. O.; O'HEARN, G. T.; GALE, C. G. Referents to scientific literacy. Journal of Research in Science Teaching, v. 4, p. 199-208, 1966.

PINHEIRO, N. A. M.; SILVEIRA, R. M. C. F.; BAZZO, W. A. Ciência, tecnologia e sociedade: A relevância do enfoque CTS para o contexto do ensino médio. Ciência \& Educação, v. 13, n. 1, p. 71-84, 2007.

POSNER, R. S. Some problems of utilitarianism. In: HARTMAN, L. P. (Ed.). Perspectives in business ethics. 2. ed. Boston: McGraw-Hill, 2002. p. 37-42.

PUIG, J. M. A construção da personalidade moral. São Paulo: Ática, 1998.

RACHELS, J. Elementos da filosofia moral. Trad.: Roberto C. Filho. 4. ed. Barueri: Manole, 2006.

RAMSEY, J. The science education reform movement: Implications for social responsibility. Science Education, v. 77, n. 2, p. 235-258, 1993.

RATCLIFFE, M. Discussing socio-scientific issues in science lessons - pupils' actions and the teacher's role. School Science Review, v. 79, n. 288, p. 55-59, 1998.

RATCLIFFE, M. Pupil decision-making about socioscientific issues, within the science curriculum. International Journal of Science Education, v. 19, n. 2, 167-182, 1997.

RATCLIFFE, M.; GRACE, M. Science education and citizenship: Teaching socio-scientific issues. Buckingham, UK: Open University Press, 2003.

RAZERA, J. C. C. O desenvolvimento moral em aulas de ciências: Explorando uma interface de contribuições. Tese de Doutorado apresentada ao Programa de Pós-graduação em Educação para a Ciência da Universidade Estadual Paulista Júlio Mesquita Filho. 2011. 236 f.

RAZERA, J. C. C.; NARDI, R. Ética no ensino de ciências: responsabilidades e compromissos com a evolução moral da criança nas discussões de assuntos controvertidos. Investigações em Ensino de Ciências, v. 11, n. 1, p. 53-66, 2006.

REIS, P. O “admirável mundo novo" em discussão. Lisboa: Ministério da Educação, Instituto de Inovação Educacional, 2003. 
REIS, P. O ensino da ética nas aulas de ciências através do estudo de casos. Interacções, Santarém, Portugal, n. 5, p. 36-45, 2007. Disponível em: <http://www.eses.pt/interaccoes>. Acesso em: 23 nov 2015.

REIS, P.; GALVÃO, C. Socio-scientific controversies and students' conceptions about scientists. International Journal of Science Education, v. 26, n. 13, p. 1621-1633, 2004.

REISS, M. Ethical thinking. In: Ethics in the Science and Technology Classroom: A New Approach to Teaching and Learning. JONES, A.; MCKIM, A.; REISS, M. (Eds.). Sense publishers, Rotterdam, 2010. p. 7-17.

REISS, M. The use of ethical frameworks by students following a new science course for 16 18 year-olds. Science and Education, v. 17, p. 889-902, 2008.

RICHARDSON, H. S. Moral Reasoning. ZALTA, E. N. (Ed.). The Stanford Encyclopedia of Philosophy, 2014. Disponível em:

$<$ http://plato.stanford.edu/archives/win2014/entries/reasoning-moral/>. Acesso em: 28 out. 2015.

ROBERTS, D. A. Scientific literacy. In: ABELL, S. K.; LEDERMAN, N. G. (Eds.).

Handbook of Research on Science Education, a project of the National Association for Research in Science Teaching, 2007. p. 729-780.

ROBERTS, D. A. Scientific literacy. Towards a balance for setting goals for school science programs. Otawa, ON, Canadá: Minister of Supply and Services, 1983.

ROTTMAN, J.; YOUNG, L. Mechanisms of moral development. In: DECETY, J.;

WHEATLEY, T. (Eds.). The moral brain: A multidisciplinary perspective. Cambridge, MA: MIT Press, 2015. p. 123-142.

RUBBA, P. Integration STS into school science and teacher education: beyond awareness. Theory into Practice, v. 30, n. 4, p. 303-315, 1991.

SADLER, T. D. Informal reasoning regarding socioscientific issues: A critical review of research. Journal of Research in Science Teaching, v. 41, p. 513-536, 2004c.

SADLER, T. D. Moral and ethical dimensions of socioscientific decision-making as integral components of scientific literacy. The Science Educator, v. 13, n. 1, p. 39-48, 2004a.

SADLER, T. D. Moral sensitivity and its contribution to the resolution of socio-scientific issues. Journal of Moral Education, v.33, p. 339-358, 2004b.

SADLER, T. D., CHAMBERS, F. W.; ZEIDLER, D. L. Student conceptualizations of the nature of science in response to a socioscientific issue. International Journal of Science Education, v. 26, p. 387-409, 2004.

SADLER, T. D.; AMIRSHOKOOHI, A.; KAZEMPOUR, M. e ALLSPAW, K. M. Socioscience and ethics in science classrooms: teacher perspectives and strategies. Journal of Research in Science Teaching, v. 43, n. 4, p. 353-376, 2006.

SADLER, T. D.; DONNELLY, L. A. Socioscientific argumentation: the effects of content knowledge and morality. International Journal of Science Education, v. 28, n. 12, 2006.

SADLER, T. D.; FOWLER, S. R. A threshold model of content knowledge transfer for socioscientific argumentation. Science Education, v. 90, n. 6, p. 986-1004, 2006.

SADLER, T. D.; ZEIDLER, D. L. Scientific Literacy, PISA, and Socioscientific Discourse: Assessment for Progressive Aims of Science Education. Journal of Research in Science Teaching, v. 46, n. 8, p. 909-921, 2009. 
SADLER, T. D.; ZEIDLER, D. L. The morality of socioscientific issues construal and resolution of genetic engineering dilemmas. Science Education, v. 88, n. 1, p. 4-27, 2004.

SADLER, T.D.; ZEIDLER, D.L. Patterns of informal reasoning in the context of socioscientific decision-making. Journal of Research in Science Education, v. 42, 112-138, 2005 .

SANTOS, W. L. P. Aspectos sociocientíficos em aulas de química. Tese de Doutorado em Educação - Faculdade de Educação, Universidade Federal de Minas Gerais, Belo Horizonte, 2002.

SANTOS, W. L. P. Ciência e educação para a cidadania. In: CHASSOT, A.; OLIVEIRA, R. J. (Orgs.). Ciência, ética e cultura na educação. São Leopoldo: Ed. Unisinos, 1998. p. 255270 .

SANTOS, W. L. P. Educação científica: Uma revisão sobre suas funções para a construção do conceito de letramento científico como prática social. Revista Brasileira de Educação, v. 12, n. 36, p. 474-492, 2007.

SANTOS, W. L. P. O ensino de Química para formar o cidadão: principais características e condições para a sua implantação na escola secundária brasileira. Dissertação (Mestrado em Educação) - Faculdade de Educação da Universidade Estadual de Campinas, 1992.

SANTOS, W. L. P. Significados da educação científica com enfoque CTS. In: SANTOS, W. L. P. e AULER, D. (Orgs). CTS e educação científica: desafios, tendências e resultados de pesquisas. Brasîlia: Editora Universidade de Brasilia. 2011, p. 21-48.

SANTOS, W. L. P.; MORTIMER, E. F. Uma Análise de Pressupostos Teóricos da Abordagem C-T-S (Ciência-Tecnologia-Sociedade) no Contexto da Educação Brasileira. Ensaio - Pesquisa em Educação em Ciências, Belo Horizonte, v. 2, n. 2, p. 01-23, 2000.

SANTOS, W. L. P.; SCHNETZLER, R. P. Educação em química: compromisso com a cidadania. 4. ed. Ijuí: Editora da Unijuí, 2010.

SASSERON, L. H. Alfabetização científica no Ensino Fundamental: Estrutura e indicadores deste processo em sala de aula. Tese de Doutorado apresentada ao Programa de Pós-Graduação em Educação faculdade de Educação da Universidade de São Paulo. 2008. 265 p.

SASSERON, L. H.; CARVALHO, A. M. P de. Alfabetização científica: uma revisão bibliográfica. Investigações em Ensino de Ciências, v. 16, n. 1, p. 59-77, 2011.

SAUNDERS, K. J.; RENNIE, L. J. A pedagogical model for ethical inquiry into socioscientific issues in science. Research in Science Education, v. 43, n. 1, p. 253-274, 2013.

SCHEID, N. M. J.; FERRARI, N. Pangênese e teoria cromossômica da herança: a persistência de idéias? Filosofia e História da Biologia, Campinas, v. 3, p. 305-316, 2008.

SCHRADER, D. E. Moral metacognition on adolescente and adulthood. In: DEMICK, J.; ANDREOLETTI, C. (Eds.). Handbook of adult development. Springer, 2003.

SCHRAMM, F. R. Existem boas razões para se temer a biotecnociência? Revista Biosthikos, v. 4, n. 2, p. 189-197, 2010. Disponível em:

$<$ http//www6.ensp.fiocruz.br/repositorio/sites/default/files/arquivos/ExistemBoasRazoes.pdf $>$ Acesso em: 11 jan 2016.

SEN, A. Desenvolvimento como liberdade. São Paulo: Companhia das Letras, 2000. 
SHEN, B. S. P. Science literacy. American Scientist, v. 63, n. 3, p. 265-268, 1975.

SHWEDER, R. A.; MAHAPATRA, M.; MILLER, J. G. Culture and moral development. In: KAGAN, J; LAMB, S. (Eds.). The emergence of morality in young children. Chicago: University of Chicago Press, 1987. p. 1-83.

SILVA, P. F.; KRASILCHIK, M. Bioética e ensino de ciências: o tratamento de temas controversos - dificuldades apresentadas por futuros professores de ciências e biologia. Ciência \& Educação, v. 19, n. 2, p. 379-392, 2013.

SILVA, S. M. B.; SANTOS, W. L. P. O lugar da moral no ensino de Ciências. Interacções, n. 31, p. 124-148, 2014.

SIMON, H. A. What is an "explanation" of behavior? Psychological Science, v. 3, p. 150$161,1992$.

SIMONNEAUX, L. Argumentation in socio-scientific contexts. In: ERDURAN, S.; JIMÉNEZ-ALEIXANDRE, M. P. (Eds). Argumentation in Science Education: Perspectives from classroom based research. USA, Tallahasse: Springer, 2008. p. 179-199.

SIMONNEAUX, L.; SIMONNEAUX, J. Students' socio-scientific reasoning on controversies from the viewpoint of education for sustainable development. Cultural Studies of Science Education, v. 4, n. 3, p. 657-687, 2009.

SINNOTT-ARMSTRONG, W. Consequentialism. In: ZALTA, E. N. (Ed.). The Stanford Encyclopedia of Philosophy, 2015. Disponível em:

<http://plato.stanford.edu/archives/win2015/entries/consequentialism/>. Acesso em: 23 abril 2014.

SJÖBERG, L. Are Received Risk Perception Models Alive and Well? Risk Analysis, V. 22, n. 4, p. 665-669, 2002.

SJÖBERG, L. Risk perception by the public and by experts: A dilemma in risk management. Human Ecology Review, v. 6, n. 2, p. 1-9, 1999.

SLOVIC, P.; PETERS, E. Risk perception and affect. Current Directions in Psychological Science, v. 15, n. 6, p. 322-325, 2006.

SOARES, M. Letramento: um tema em três gêneros, Belo Horizonte: Autêntica, 1998.

SOLOMON, J. Teaching science, technology and society. Buckingham: Open University Press, 1993.

SOLOMON, J. The classroom discussion of science-based social issues presented on television: knowledge, attitudes and values. International Journal of Science Education, v. 14, n. 4, p. 431-444, 1992.

SOLOMON, J. The discussion of social issues in the science classroom. Studies in Science Education, v. 18, n. 1, p. 105-126, 1990.

STERNÄNG, L.; LUNDHOLM, C. Climate change and morality: students' perspectives on the individual and society. International Journal of Science Education, v. 33, n. 8, 2011.

THIOLLENT, M. Metodologia da pesquisa-ação (Coleção temas básicos de pesquisa-ação). 2 ed. São Paulo: Cortez, 1986.

THIOLLENT, M. Pesquisa-Ação nas Organizações. Ed. Atlas. São Paulo, 1997. 
TOBIN, K.; LAMASTER, S. U. Relationships between metaphors, beliefs, and actions in a context of science curriculum change. Journal of Research in Science Teaching, v. 32, p. 225-242, 1995.

TURIEL, E. The development of social knowledge: Morality and convention. Cambridge, England: Cambridge University Press, 1983.

UNESCO. Universal Declaration on Bioethics and Human Rights. Paris: Unesco; 2005.

VALENTE, M. O. Ensino das ciências e cidadania. Conferência plenária apresentada no VIII Encontro de Ensino das Ciências, Ponta Delgada, Portugal, nov. 2000. Disponível em: < http://www.educ.fc.ul.pt/docentes/mvalente/texto_Acores.pdf>. Acesso em: 9 mar 2016.

VÁSQUEZ, A. S. Ética. São Paulo: Civilização Brasileira, 1989.

VENVILLE, G. J.; DAWSON, V. M. The Impact of a Classroom Intervention on Grade 10

Students' Argumentation Skills, Informal Reasoning, and Conceptual Understanding of Science. Journal of Research in Science Teaching, v. 47, n. 8, p. 952-977, 2010.

VON AUFSCHNAITER, C.; ERDURAN, S.; OSBORNE, J.; SIMON, S. Arguing to Learn and Learning to Argue: Case Studies of How Students' Argumentation Relates to Their Scientific Knowledge. Journal of Research in Science Teaching, v. 45, n. 1, p. 101-131, 2008.

WAKS, L. J. Educación en ciencia, tecnología y sociedad: orígenes, dessarrollos internacionales y desafíos actuales. In: MEDINA, M.; SANMARTÍN, J. (Eds.). Ciencia, tecnología y sociedad: estudios interdisciplina res en la universidad, en la educación y en la gestión pública. Barcelona, Anthropos; Leioa (Vizcaya), Univesidad del País Vasco, 1990. p. $42-75$.

WALKER, K. A.; ZEIDLER, D. L. Promoting discourse about socioscientific issues through scaffolded inquiry. International Journal of Science Education, v. 29, p. 1387-1410, 2007.

WORLD ANTI-DOPING AGENCY (WADA-AMA). World anti-doping code. (Version 3). WADA, Montreal, 2003. Disponível em: https $/ /$ wada-mainprod.s3.amazonaws.com/resources/files/wada_code_2003_en.pdf. Acesso em: 27 fev. 2016.

WU, Y. T.; TSAI, C. C. High school students' preference and reasoning on a socioscientific issue: qualitative and quantitative analyses. International Journal of Science Education, v. 29, n. 9, p. 1163-1187, 2007

YAGER, R. E. Science-technology-society as reform. School Science and Mathematics, v. 93, p. 145-151, 1993.

ZEIDLER, D. L.; KEEFER, M. The role of moral reasoning and the status of socioscientitifc issues in science education: philosophical, psychological and pedagogical considerations. In: ZEIDLER, D. L. (Ed.). The role of moral reasoning and discourse on socioscientific issues in science education. Dordrecht: Kluwer, 2003. p. 7-38.

ZEIDLER, D. L.; LEWIS, J. Unifying themes in moral reasoning on socioscientific issues and discourse. In: ZEIDLER, D. L. (Ed.). The role of moral reasoning on socioscientific issues and discourse in science education. Dordrecht, The Netherlands: Kluwer Academic Press, 2003. p. 289-306.

ZEIDLER, D. L.; OSBORNE, J.; ERDURAN, S.; SIMON, S.; MONK, M. The role of argument during discourse about socioscientific issues. In: ZEIDLER, D. L. (Ed.). The role of moral reasoning on socioscientific issues and discourse in Science Education. Dordrecht /Boston / London: Kluwer Academic publishers, 2003. p. 97-116. 
ZEIDLER, D. L.; SADLER, T. D.; SIMMONS, M. L.; HOWES, E. V. Beyond STS: A research-based framework for socioscientific issues education. Science Education, v. 89, n. 3, p. 357-377, 2005.

ZEIDLER, D. L.; WALKER, K. A.; ACKETT, W. A.; SIMMONS, M. L. Tangled up in views: Beliefs in the nature of science and responses to socioscientific dilemmas. Science Education, v. 86, p. 343-367, 2002.

ZEIDLER, D. Moral Issues and Social Policy in Science Education: Closing the Literacy Gap. Science Education, v. 68, n. 4 p. 411-419, 1984.

ZOHAR, A.; NEMET, F. Fostering students' knowledge and argumentation skills through dilemmas in human genetics. Journal of Research in Science Teaching, v. 39, p. 35-62, 2002. 

APÊNDICES 


\section{APÊNDICE A - RELAÇÃO DE ARTIGOS SOBRE QUESTÕES SOCIOCIENTÍFICAS}

\begin{tabular}{|c|c|}
\hline No & Artigo \\
\hline 1 & $\begin{array}{l}\text { SAUNDERS, K. J.; RENNIE, L. J. A. Pedagogical Model for Ethical Inquiry into } \\
\text { Socioscientific Issues in Science, 43, 1, } 2013 \text {. }\end{array}$ \\
\hline 2 & $\begin{array}{l}\text { BOTTCHER, F.; MEISERT, A. Effects of Direct and Indirect Instruction on Fostering } \\
\text { Decision-Making Competence in Socioscientific Issues, 43, 2, } 2013 \text {. }\end{array}$ \\
\hline 3 & $\begin{array}{l}\text { EKBORG, M.; OTTANDER, C.; SILFVER, E.; SIMON, S. Teachers' Experience of Working } \\
\text { with Socio-Scientific Issues: A Large Scale and in Depth Study, 43, 2, } 2013 .\end{array}$ \\
\hline 4 & $\begin{array}{l}\text { EASTWOOD, J. L.; SADLER, T. D.; SHERWOOD, R. D.; SCHLEGEL, W. M. Students' } \\
\text { Participation in an Interdisciplinary, Socioscientific Issues Based Undergraduate Human } \\
\text { Biology Major and Their Understanding of Scientific Inquiry, } 43,3,2013 \text {. }\end{array}$ \\
\hline 5 & $\begin{array}{l}\text { AHMET, K.; TEZCAN, K.; BARIŞ, E; ÜMIT, D.; ÖZLEM, A.; DILBER, P.; MUTLU P. D. } \\
\text { G.; ÖZKAN, G. Preservice Science Teachers' Efficacy Regarding a Socioscientific Issue:a } \\
\text { Belief System Approach,43, 6, 2013. }\end{array}$ \\
\hline 6 & $\begin{array}{l}\text { ROBOTTOM, I. Socio-scientific Issues in Education: Innovative Practices and Contending } \\
\text { Epistemologies, } 42,1,2012 \text {. }\end{array}$ \\
\hline 7 & $\begin{array}{l}\text { TOMAS, L; RITCHIE, S. M. Positive Emotional Responses to Hybridised Writing about a } \\
\text { Socio-Scientific Issue, } 42,2,2012 \text {. }\end{array}$ \\
\hline 8 & $\begin{array}{l}\text { KLOSTERMAN, M. L.; SADLER, T. D.; BROWN, J. Science Teachers' Use of Mass Media } \\
\text { to Address Socio-Scientific and Sustainability Issues, } 42,1,2012 \text {. }\end{array}$ \\
\hline 9 & $\begin{array}{l}\text { SIMONNEAUX, J.; SIMONNEAUX, L. Educational Configurations for Teaching } \\
\text { Environmental Socioscientific Issues within the Perspective of Sustainability, 42, 1, } 2012 .\end{array}$ \\
\hline 10 & RUSSELL, T. Socios-Scientific Issues, Sustainability and Science Education, 42, 1, 2012. \\
\hline 11 & $\begin{array}{l}\text { OTTANDER, C.; EKBORG, M. Students Experience of Working with Socioscientific Issues - } \\
\text { A quantitative Study in Secondary School, } 42,6,2012 \text {. }\end{array}$ \\
\hline 12 & $\begin{array}{l}\text { JONES, A.; BUNTTING, C.; HIPKINS, R.; MCKIM, A.; CONNER, L.; SAUNDERS, K. } \\
\text { Developing Students' Futures Thinking in Science Education, 42, 4, } 2012 .\end{array}$ \\
\hline 13 & $\begin{array}{l}\text { ORLANDER, A. A.; LUNDERGARD, I. "It's Her Body". When Students' Argumentation } \\
\text { Shows Displacement of Content in a Science Classroom, 42, 6, } 2012 .\end{array}$ \\
\hline 14 & $\begin{array}{l}\text { BENCZE, L.; SPERLING, E; CARTER, L. Students' Research-Informed Socio-Scientific } \\
\text { Activism: Re/Visions for a Sustainable Future, 42, 1, } 2012 \text {. }\end{array}$ \\
\hline 15 & $\begin{array}{l}\text { BRAVO-TORIJA, B.; JIMENEZ-ALEIXANDRE, M. P. Progression in Complexity: } \\
\text { Contextualizing Sustainable Marine Resources Management in a } 10^{\text {th }} \text { Grade Classroom, 42, 1, } \\
2012 \text {. }\end{array}$ \\
\hline
\end{tabular}




\begin{tabular}{|c|c|}
\hline 16 & $\begin{array}{l}\text { LANGE, J. M. Education in Sustainable Development: How Can Science Education Contribute } \\
\text { to the Vulnerability Perception? 42, 1, } 2012 .\end{array}$ \\
\hline 17 & PRAIN, V. Acting on Sustainability, 42, 1, 2012. \\
\hline 18 & $\begin{array}{l}\text { WU, Y. T.; TSAI, C. C. The effects of Different On-Line Searching Activities on High School } \\
\text { Students' Cognitive Structures and Informal Reasoning Regarding a Socio-Scientific Is sue, } 41 \text {, } \\
\text { 5, } 2011 \text {. }\end{array}$ \\
\hline 19 & $\begin{array}{l}\text { DAWSON, V. M.; VENVILLE, G. Teaching Strategies for Developing Students' } \\
\text { Argumentation Skills about Socioscientific Issues in High School Genetics, 40, 2, } 2010 .\end{array}$ \\
\hline 20 & $\begin{array}{l}\text { MENZEL, S.; BOGEHOLZ, S. The Loss of Biodiversity as a Challenge for Sustainable } \\
\text { Development: How Do Pupils in Chile and Germany Perceive Resource Dillemas? 39, 4, } 2009 .\end{array}$ \\
\hline 21 & $\begin{array}{l}\text { DA VIDSON, E. Enhancing Visitors' Interest in Science - A Possibility or A Paradox? 39, 2, } \\
2009 .\end{array}$ \\
\hline 22 & $\begin{array}{l}\text { SMITH, D. V.; GUNSTONE, R. F. Science Curriculum in the Market Liberal Society of the } \\
\text { Twenty-first Century: 'Re-visioning' the Idea of Science for All, 39, 1, } 2009 .\end{array}$ \\
\hline 23 & $\begin{array}{l}\text { ALBE, V. When Scientific Knowledge, Daily Life Experience, Epistemological and Social } \\
\text { Considerations Intersect: Students' Argumentation in Group Discussions on a Socio-Scientific } \\
\text { Issue, } 38,1,2008 \text {. }\end{array}$ \\
\hline 24 & $\begin{array}{l}\text { CASTANO, C. Socio-Scientific Discussions as a Way to Improve the Comprehension of } \\
\text { Science and the Understanding of the Interrelation between Species and the Environment, 38, } \\
5,2008 \text {. }\end{array}$ \\
\hline 25 & $\begin{array}{l}\text { SADLER, T. D.; BARAB, S. A.; SCOTT, B. What do Students Gain by Engaging in } \\
\text { Socioscientific Inquiry? 37, 4, } 2007 \text {. }\end{array}$ \\
\hline 26 & $\begin{array}{l}\text { REIS, P.; GALVÃO, C. The Impact of Socio-Scientific Controversies in Portuguese Natural } \\
\text { Science Teachers' Conceptions and Practices, 34, 2, } 2004 .\end{array}$ \\
\hline 27 & $\begin{array}{l}\text { FOUNTAIN, R. M. Sociologics: Na Analytical Tool for Examining Socioscientific Discourse, } \\
\text { 28, 1, } 1998 .\end{array}$ \\
\hline & 2. Cultural Studies of Science Education \\
\hline 28 & $\begin{array}{l}\text { WARE, M. The Shape of Our Bodies and Health: Deconstructing the Panopticon of Separation } \\
\text { towards an Empowered Dance "through" the World, 8, 1, } 2013 .\end{array}$ \\
\hline 29 & $\begin{array}{l}\text { LEVINSON, R. A Perspective on Knowing about Global Warming and a Critical Comment } \\
\text { about Schools and Curriculum in Relation to Socio-Scientific Issues 7, 3, } 2012 .\end{array}$ \\
\hline 30 & $\begin{array}{l}\text { ALBE, V.; GOMBERT, M. J. Students' Communication, Argumentation and Knowledge in a } \\
\text { Citizens' Conference on Global Warming, 7, 3, } 2012 \text {. }\end{array}$ \\
\hline 31 & $\begin{array}{l}\text { LUNDSTROM, M.; EKBORG, M.; IDELAND, M. To Vaccinate or Not to Vaccinate: How } \\
\text { Teenagers Justified Their Decision, 7, 1, } 2012 .\end{array}$ \\
\hline 32 & $\begin{array}{l}\text { IDELAND, M.; MALMBERG, C. Body Talk: Students' Identity Construction while Discussing } \\
\text { a Socioscientific Issue, 7, 2, } 2012 \text {. }\end{array}$ \\
\hline 33 & GAUTIER, C. A New Type of Debate for Global Warming and Scientific Literacy, 7, 3, 2012. \\
\hline
\end{tabular}




\begin{tabular}{|c|c|}
\hline 34 & $\begin{array}{l}\text { ALLGAIER, J. The difficulty of differentiating expertise and the functions of expert sources } \\
\text { and the necessity of studying science education in the media, } 6,2,2011 \text {. }\end{array}$ \\
\hline 35 & $\begin{array}{l}\text { SADLER, T. Socioscientific Issues in Science Education: Labels, Reasoning, and Transfer, 4, } \\
3,2009 .\end{array}$ \\
\hline 36 & $\begin{array}{l}\text { SIMONNEAUX, L; SIMONNEAUX, J. Students' Socio-Scientific Reasoning on } \\
\text { Controversies from the Viewpoint of Education for Sustainable Development, 4, 3, 2009. }\end{array}$ \\
\hline 37 & $\begin{array}{l}\text { LOPEZ-FACAL, R.; JIMENEZ-ALEIXANDRE, M. P. Identities, Social Representations and } \\
\text { Critical Thinking, 4, 3, } 2009 .\end{array}$ \\
\hline 38 & $\begin{array}{l}\text { SIMONNEAUX, L.; SIMONNEAUX, J. Socio-scientific reasoning influenced by identities, } 4 \text {, } \\
3,2009 \text {. }\end{array}$ \\
\hline & 3. Science \& Education \\
\hline 39 & $\begin{array}{l}\text { BARRUE, C.; ALBE, V. Citizenship Education and Socioscientific Issues: Implicit Concept of } \\
\text { Citizenship in the Curriculum, Views of French Middle School Teachers, 2, 5, } 2013 .\end{array}$ \\
\hline 40 & $\begin{array}{l}\text { ALLGAIER, J. Scientific Experts and the Controversy about Teaching Creation/Evolution in } \\
\text { the UK Press, } 9,6-8,2010 .\end{array}$ \\
\hline 41 & $\begin{array}{l}\text { ALBE, V. Students' Positions and Considerations of Scientific Evidence about a Controversial } \\
\text { Socioscientific Issue, } 7,8-9,2008 .\end{array}$ \\
\hline 42 & $\begin{array}{l}\text { LEVINSON, R. Promoting the Role of the Personal Narrative in Teaching Controversial Socio- } \\
\text { Scientific Issues, 7, 8-9, } 2008 \text {. }\end{array}$ \\
\hline 43 & $\begin{array}{l}\text { FORBES, C. T.; DA VIS, E. A. Exploring Preservice Elementary Teachers' Critique and } \\
\text { Adaptation of Science Curriculum Materials in Respect to Socioscientific Issues, 7, 8-9, } 2008 .\end{array}$ \\
\hline 44 & $\begin{array}{l}\text { KOLSTØ, S. D. Science Education for Democratic Citizenship through the Use of the History } \\
\text { of Science, 7, 8-9, } 2008 \text {. }\end{array}$ \\
\hline 45 & $\begin{array}{l}\text { HANEGAN, N. L; PRICE, L.; PETERSON, J. Disconnections between Teacher Expectations } \\
\text { and Student Confidence in Bioethics, 7, 8-9, } 2008 .\end{array}$ \\
\hline & 4. International Journal of Science Education \\
\hline 46 & $\begin{array}{l}\text { RYDER, J.; BANNER, I. School Teachers' Experiences of Science Curriculum Reform, 35, 3, } \\
\text { 2013. }\end{array}$ \\
\hline 47 & $\begin{array}{l}\text { JONES, M. G.; BLONDER, R.; GARDNER, G. E.; ALBE, V. Nanotechnology and nanoscale } \\
\text { science: educational challenges, 35, 9, } 2013 \text {. }\end{array}$ \\
\hline 48 & KHISHFE, R. Nature of Science and Decision-Making, 34, 1, 2012. \\
\hline 49 & $\begin{array}{l}\text { LEE, H.; CHANG, H.; CHOI, K.; KIM, S. W.; ZEIDLER, D. L. Developing Character and } \\
\text { Values for Global Citizens: Analysis of Pre-Service Science Teachers' Moral Reasoning on } \\
\text { Socioscientific Issues, } 34,6,2012 \text {. }\end{array}$ \\
\hline 50 & $\begin{array}{l}\text { EASTWOOD, J. L.; SADLER, T. D.; ZEIDLER, D. L.; LEWIS, A.; AMIRI, L.; } \\
\text { APPLEBAUM, S. Contextualizing Nature of Science Instruction in Socioscientific Issues, } 34 \text {, } \\
15,2012 .\end{array}$ \\
\hline 51 & LEE, Y. C. Socio-Scientific Issues in Health Contexts: Treading a Rugged Terrain, 34, 3, 2012. \\
\hline
\end{tabular}




\begin{tabular}{|c|c|}
\hline 52 & $\begin{array}{l}\text { NIELSEN, J. A. Arguing from Nature: The Role of "Nature" in Students' Argumentations on a } \\
\text { Socio-Scientific Issue, 34, 5, } 2012 .\end{array}$ \\
\hline 53 & $\begin{array}{l}\text { NIELSEN, J. A. Co-Opting Science: A Preliminary Study of How Students Invoke Science in } \\
\text { Value-Laden Discussions, 34, 2, } 2012 \text {. }\end{array}$ \\
\hline 54 & $\begin{array}{l}\text { FRANCE, B.; MORA, H. A.; BAY, J. L. Changing Perspectives: Exploring a Pedagogy to } \\
\text { Examine Other Perspectives about Stem Cell Research, 34, 5, } 2012 .\end{array}$ \\
\hline 55 & $\begin{array}{l}\text { SCHALK, K. A. A Socioscientific Curriculum Facilitating the Development of Distal and } \\
\text { Proximal NOS Conceptualizations, } 34,1,2012 \text {. }\end{array}$ \\
\hline 56 & $\begin{array}{l}\text { EVAGOROU, M.; JIMENEZ-ALEIXANDRE, M.P.; OSBORNE, J. "Should We Kill the Grey } \\
\text { Squirrels?" A Study Exploring Students'Justifications and Decision-Making, 34, 3, } 2012 .\end{array}$ \\
\hline 57 & $\begin{array}{l}\text { CRNE-HLADNIK, H.; HLADNIK, A.; JAVORNIK, B.; KOSMELJ, K.; PEKLAJ, C. Is } \\
\text { Judgement of Biotechnological Ethical Aspects Related to High School Students' Knowledge? } \\
34,8,2012 \text {. }\end{array}$ \\
\hline 58 & $\begin{array}{l}\text { CALIK, M.; COLL, R. K. Investigating Socioscientific Issues via Scientific Habits of Mind: } \\
\text { Development and Validation of the Scientific Habits of Mind Survey, 34, 12, } 2012 .\end{array}$ \\
\hline 59 & $\begin{array}{l}\text { FOONGAND, C. C.; DANIEL, E. G. S. Students' Argumentation Skills across Two Socio- } \\
\text { Scientific Is sues in a Confucian Classroom: Is transfer possible? iFirst article, } 2012 .\end{array}$ \\
\hline 60 & $\begin{array}{l}\text { LEE, H.; YOO, J; CHOI, K; KIM, S. W.; KRAJCIK, J.; HERMAN, B. C.; ZEIDLER, D. L. } \\
\text { Socioscientific Issues as a Vehicle for Promoting Character and Values for Global Citizens, } \\
\text { iFirst article, } 2012 \text {. }\end{array}$ \\
\hline 61 & $\begin{array}{l}\text { IDELAND, M; MALMBERG, C.; WINBERG, M. Culturally Equipped for Socio-Scientific } \\
\text { Issues? A comparative study on how teachers and students in mono-and multiethnic schools } \\
\text { handle work with complex is sues, } 33,13,2011 \text {. }\end{array}$ \\
\hline 62 & $\begin{array}{l}\text { DAY, S. P.; BRYCE, T. G. K. Does the Discussion of Socio-Scientific Issues require a } \\
\text { Paradigm Shift in Science Teachers' Thinking? 33, 12, } 2011 \text {. }\end{array}$ \\
\hline 63 & $\begin{array}{l}\text { STERNANG, L.; LUNDHOLM, C. Climate Change and Morality: Students' Perspectives on } \\
\text { the Individual and Society, 33, 8, } 2011 .\end{array}$ \\
\hline 64 & $\begin{array}{l}\text { RITCHIE, S. M.; TOMAS, L.; TONES, M. Writing Stories to Enhance Scientific Literacy, 33, } \\
\text { 5, } 2011 .\end{array}$ \\
\hline 65 & $\begin{array}{l}\text { GARDNER, G.; JONES, G. Perceptions and Practices: Biology Graduate Teaching Assistants' } \\
\text { Framing of a Controversial Socioscientific Is sue, 33, 8, } 2011 .\end{array}$ \\
\hline 66 & $\begin{array}{l}\text { ABI-EL-MONA, I.; ABD-EL-KHALICK, F. Perceptions of the Nature and "Goodness" of } \\
\text { Argument among College Students, Science, 33, 4, } 2011 .\end{array}$ \\
\hline 67 & $\begin{array}{l}\text { RYDER, J.; BANNER, I. Multiple Aims in the Development of a Major Reform of the National } \\
\text { Curriculum for Science in England, 33, 5, } 2011 .\end{array}$ \\
\hline 68 & $\begin{array}{l}\text { WU, Y. T.; TSAI, C. C. High School Students' Informal Reasoning Regarding a Socio- } \\
\text { Scientific Issue, with Relation to Scientific Epistemological Beliefs and Cognitive Structures, } \\
\text { 33, 3, 2011. }\end{array}$ \\
\hline
\end{tabular}




\begin{tabular}{|c|c|}
\hline 69 & $\begin{array}{l}\text { ACAR, O.; TURKMEN, L.; ROYCHOUDHURY, A. Student Difficulties in Socio-Scientific } \\
\text { Argumentation and Decision-Making Research Findings: Crossing the Borders of Two } \\
\text { Research Lines, 32, 9, } 2010 .\end{array}$ \\
\hline 70 & $\begin{array}{l}\text { TOPCU, M. S.; SADLER, T. D.; YILMAZ-TUZUN, O. Preservice Science Teachers' Informal } \\
\text { Reasoning about Socioscientific Issues:The Influence of Issue Context, 32, 18, } 2010 .\end{array}$ \\
\hline 71 & $\begin{array}{l}\text { KLOSTERMAN, M. L.; SADLER, T. D. Multi-Level Assessment of Scientific Content } \\
\text { Knowledge Gains Associated with Socioscientific Issues-Based Instruction, 32, 8, } 2010 .\end{array}$ \\
\hline 72 & $\begin{array}{l}\text { LEE, Y. C. Science-Technology-Society or Technology-Society-Science? Insights from an } \\
\text { Ancient Technology, 32, 14, } 2010 .\end{array}$ \\
\hline 73 & $\begin{array}{l}\text { MOLINATTI, G.; GIRAULT, Y.; HAMMOND, C. High School Students Debate the Use of } \\
\text { Embryonic Stem Cells: The Influence of Context on Decision-Making, 32, 16, } 2012 .\end{array}$ \\
\hline 74 & $\begin{array}{l}\text { FOWLER, S. R.; ZEIDLER, D. L.; SADLER, T. D. Moral Sensitivity in the Context of } \\
\text { Socioscientific Issues in High School Science Students, 31, 2, } 2009 .\end{array}$ \\
\hline 75 & $\begin{array}{l}\text { LEE, H.; WITZ, K. G. Science Teachers' Inspiration for Teaching Socio-Scientific Issues: } \\
\text { Disconnection with Reform Efforts, 31, 7, } 2009 .\end{array}$ \\
\hline 76 & $\begin{array}{l}\text { KNIPPELS, M. C. P. J.; SEVERIENS, S. E.; KLOP, T. Education through Fiction: Acquiring } \\
\text { Opinion-Forming Skills in the Context of Genomics, 31, 15, } 2009 .\end{array}$ \\
\hline 77 & $\begin{array}{l}\text { HALVERSON, K. L.; SIEGEL, M. A.; FREYERMUTH, S. K. Lenses for Framing Decisions: } \\
\text { Undergraduates' Decision Making about Stem Cell Research, 31, 9, } 2009 .\end{array}$ \\
\hline 78 & $\begin{array}{l}\text { GRACE, M. Developing High Quality Decision-Making Discussions about Biological } \\
\text { Conservation in a Normal Classroom Setting, } 31,4,2009 .\end{array}$ \\
\hline 79 & $\begin{array}{l}\text { DAWSON, V.; VENVILLE, G. J. High-school Students' Informal Reasoning and } \\
\text { Argumentation about Biotechnology: An indicator of scientific literacy? 31, 11, } 2009 .\end{array}$ \\
\hline 80 & $\begin{array}{l}\text { DAWSON, V.; VENVILLE, G. J. Student Difficulties in Socio-scientific Argumentation and } \\
\text { Decision-making Research Findings: Crossing the borders of two research lines, iFirst article, } \\
2009 \text {. }\end{array}$ \\
\hline 81 & $\begin{array}{l}\text { CHANG, S. N.; CHIU, M. H. Lakatos' Scientific Research Programmes as a Framework for } \\
\text { Analysing Informal Argumentation about Socio-Scientific Issues, 30, 13, } 2008 .\end{array}$ \\
\hline 82 & $\begin{array}{l}\text { FURBERG, A.; LUDVIGSEN, S. Students' Meaning-Making of Socio-Scientific Issues in } \\
\text { Computer Mediated Settings: Exploring Learning through Interaction Trajectories, 30, 13, } \\
2008 .\end{array}$ \\
\hline 83 & $\begin{array}{l}\text { LEE, Y. C. Exploring the Roles and Nature of Science: A case study of severe acute respiratory } \\
\text { syndrome, } 30,4,2008 .\end{array}$ \\
\hline 84 & $\begin{array}{l}\text { WALKER, K. A.; ZEIDLER, D. L. Promoting Discourse about Socioscientific Issues through } \\
\text { Scaffolded Inquiry, 29, 11, } 2007 \text {. }\end{array}$ \\
\hline 85 & $\begin{array}{l}\text { WU, Y. T.; TSAI, C. C. High School Students' Informal Reasoning on a Socio-Scientific Issue: } \\
\text { Qualitative and Quantitative Analyses, 29, 9, } 2007 .\end{array}$ \\
\hline 86 & $\begin{array}{l}\text { MEISNER, R.; VON LEHN, D.; HEATH, C.; BURCH, A.; GAMMON, B.; REISMAN, M. } \\
\text { Exhibiting Performance: Co-Participation in Science Centres and Museums, 29, 12, } 2007 .\end{array}$ \\
\hline
\end{tabular}




\begin{tabular}{|c|c|}
\hline 87 & $\begin{array}{l}\text { LEHR, J. L.; MCCALLIE, E.; DAVIES, S. R.; CARON, B. R.; GAMMON, B.; DUENSING, } \\
\text { S. The Value of "Dialogue Events" as Sites of Learning: An Exploration of Research and } \\
\text { Evaluation Frameworks, 29, 12, } 2007 .\end{array}$ \\
\hline 88 & $\begin{array}{l}\text { LEVINSON, R. Towards a Theoretical Framework for Teaching Controversial Socio-Scientific } \\
\text { Issues, } 28,10,2006 .\end{array}$ \\
\hline 89 & $\begin{array}{l}\text { KOLSTØ, S. D. Patterns in Students' Argumentation Confronted with a Risk-Focused Socio- } \\
\text { Scientific Issue, } 28,14,2006 .\end{array}$ \\
\hline 90 & $\begin{array}{l}\text { ELLIOTT, P. Reviewing Newspaper Articles as a Technique for Enhancing the Scientific } \\
\text { Literacy of Student-Teachers, } 28,11,2006 .\end{array}$ \\
\hline 91 & $\begin{array}{l}\text { SADLER, T. D.; DONNELLY, L. A. Socioscientific Argumentation: The Effects of Content } \\
\text { Knowledge and Morality, 28, 12, } 2006 \text {. }\end{array}$ \\
\hline 92 & $\begin{array}{l}\text { LEWIS, J.; LEACH, J. Discussion of Socio-scientific Issues: The role of science knowledge, } \\
28,11,2006 .\end{array}$ \\
\hline 93 & $\begin{array}{l}\text { MARTÍN-DIAS, M. J. Educational background, teaching experience and teachers' views on } \\
\text { the inclusion of nature of science in the science curriculum, } 28,10,2006 .\end{array}$ \\
\hline 94 & $\begin{array}{l}\text { EKBORG, M. Student-Teachers' Learning Outcomes during Science Subject Matter Courses, } \\
27,14,2005 .\end{array}$ \\
\hline 95 & $\begin{array}{l}\text { SADLER, T. D.; CHAMBERS, W. F.; ZEIDLER, D. L. Student Conceptualizations of the } \\
\text { Nature of Science in Response to a Socioscientific Issue. Research Report, 26, 4, } 2004 .\end{array}$ \\
\hline 96 & $\begin{array}{l}\text { REIS, P.; GALVÃO, C. Socio-Scientific Controversies and Students' Conceptions about } \\
\text { Scientists, 26, 13, 2004. }\end{array}$ \\
\hline 97 & $\begin{array}{l}\text { BRYCE, T.; GRAY, D. Tough acts to follow: the challenges to science teachers presented by } \\
\text { biotechnological progress }, 26,14,2004 \text {. }\end{array}$ \\
\hline 98 & $\begin{array}{l}\text { YANG, F. Y. Exploring High School Students' Use of Theory and Evidence in an Everyday } \\
\text { Context: The Role of Scientific Thinking in Environmental Science Decision-Making, 26, 11, } \\
\text { 2004. }\end{array}$ \\
\hline 99 & $\begin{array}{l}\text { OULTON, C.; DILLON, J.; GRACE, M. M. Reconceptualizing the teaching of controversial } \\
\text { issues, 26, 4, } 2004 \text {. }\end{array}$ \\
\hline 100 & $\begin{array}{l}\text { GRACE, M. M.; RATCLIFFE, M. The science and values that young people draw upon to } \\
\text { make decisions about biological conservation issues, } 24,11,2002 \text {. }\end{array}$ \\
\hline 101 & $\begin{array}{l}\text { JIMÉNEZ-ALEIXANDRE, M. P. Knowledge producers or knowledge consumers? } \\
\text { Argumentation and decision making about environmental management, 24, 11, } 2002 .\end{array}$ \\
\hline 102 & $\begin{array}{l}\text { KOLST } \varnothing, \text { S. D. 'To Trust or Not to Trust' Pupils Ways of Judging Information Encountered in } \\
\text { a Socio-Scientific Issue. } 23,9,2001 .\end{array}$ \\
\hline 103 & $\begin{array}{l}\text { TYTLER, R.; DUGGAN, S.; GOTT, R. Dimensions of Evidence, the Public Understanding of } \\
\text { Science and Science Education, 23, 8, } 2001 .\end{array}$ \\
\hline 104 & KNAIN, E. Ideologies in schoolscience textbooks, 23, 3, 2001. \\
\hline 105 & KOLSTØ, S. D. Consensus Projects: Teaching Science for Citizenship. 22, 6, 2000. \\
\hline
\end{tabular}




\begin{tabular}{|c|c|}
\hline 106 & $\begin{array}{l}\text { PATRONIS, T.; POTARI, D.; SPILIOTOPOULOU, V. Students'Argumentation in Decision- } \\
\text { Making on a Socio-Scientific Issue: Implications for Teaching. 21, 7, } 1999 .\end{array}$ \\
\hline 107 & $\begin{array}{l}\text { RATCLIFFE, M. Pupil decision-making about socio-scientific issues within the science } \\
\text { curriculum, 19, 2, } 1997 .\end{array}$ \\
\hline \multicolumn{2}{|r|}{ 5. Journal of Research in Science Teaching } \\
\hline 108 & $\begin{array}{l}\text { ZEIDLER, D. L.; HERMAN, B. C.; RUZEK, M.; LINDER, A.; LIN, S. S. Cross-Cultural } \\
\text { Epistemological Orientations to Socioscientific Issues, } 50,3,2013 \text {. }\end{array}$ \\
\hline 109 & $\begin{array}{l}\text { EVAGOROU, M.; OSBORNE, J. Exploring Young Students' Collaborative Argumentation } \\
\text { within a Socioscientific Issue, 50, 2, } 2013 \text {. }\end{array}$ \\
\hline 110 & $\begin{array}{l}\text { SHARI, L. R.; BARTON, C. A. Should Great Lakes City Build a New Power Plant? How Youth } \\
\text { Navigate Socioscientific Issues, 49, 5, } 2012 .\end{array}$ \\
\hline 111 & $\begin{array}{l}\text { KHISHFE, R. Relationship between Nature of Science Understandings and Argumentation } \\
\text { Skills: A Role for Counterargument and Contextual Factors, } 49,4,2012 .\end{array}$ \\
\hline 112 & $\begin{array}{l}\text { NICOLAIDOU, I.; KYZA, E. A.; TERZIAN, F.; HADJICHAMBIS, A.; KAFOURIS, D. A } \\
\text { Framework for Scaffolding Students' Assessment of the Credibility of Evidence, 48, 7, } 2011 .\end{array}$ \\
\hline 113 & $\begin{array}{l}\text { TOMAS, L.; RITCHIE, S. M.; TONES, M. Attitudinal Impact of Hybridized Writing about a } \\
\text { Socioscientific Issue, } 48,8,2011 \text {. }\end{array}$ \\
\hline 114 & $\begin{array}{l}\text { BARRETT, S. E.; NIESW ANDT, M. Teaching about Ethics through Socioscientific Issues in } \\
\text { Physics and Chemistry: Teacher Candidates' Beliefs, } 47,4,2010 .\end{array}$ \\
\hline 115 & $\begin{array}{l}\text { VENVILLE, G. J.; DAWSON, V. M. The Impact of a Classroom Intervention on Grade } 10 \\
\text { Students' Argumentation Skills, Informal Reasoning, and Conceptual Understanding of } \\
\text { Science, } 47,8,2010 \text {. }\end{array}$ \\
\hline 116 & $\begin{array}{l}\text { RATCLIFFE, M.; MILLAR, R. Teaching for Understanding of Science in Context: Evidence } \\
\text { from the Pilot Trials of the "Twenty First Century Science" Courses , 46, 8, } 2009 .\end{array}$ \\
\hline 117 & $\begin{array}{l}\text { SADLER, T. D.; ZEIDLER, D. L. Scientific Literacy, PISA, and Socioscientific Discourse: } \\
\text { Assessment for Progressive Aims of Science Education, } 46,8,2009 .\end{array}$ \\
\hline 118 & $\begin{array}{l}\text { ZEIDLER, D. L.; SADLER, T. D.; APPLEBAUM, S.; CALLAHAN, B. E. Advancing } \\
\text { Reflective Judgment through Socioscientific Issues } 46,1,2009 .\end{array}$ \\
\hline 119 & $\begin{array}{l}\text { FENSHAM, P. J. Real World Contexts in PISA Science: Implications for Context-Based } \\
\text { Science Education, 46, 8, } 2009 .\end{array}$ \\
\hline 120 & $\begin{array}{l}\text { YOON, S. Using Memes and Memetic Processes to Explain Social and Conceptual Influences } \\
\text { on Student Understanding about Complex Socio-Scientific Issues, 45, } 2008 .\end{array}$ \\
\hline 121 & $\begin{array}{l}\text { VAN EIJCK, M.; ROTH, W. M. Representations of Scientists in Canadian High School and } \\
\text { College Textbooks, 45, 9, } 2008 .\end{array}$ \\
\hline 122 & $\begin{array}{l}\text { HOKAYEM, H.; BOUJAOUDE, S. College Students' Perceptions of the Theory of Evolution, } \\
45,4,2008 .\end{array}$ \\
\hline 123 & $\begin{array}{l}\text { CLARK, D. B.; SAMPSON, V. Assessing Dialogic Argumentation in Online Environments to } \\
\text { Relate Structure, Grounds, and Conceptual Quality, } 45,3,2008 \text {. }\end{array}$ \\
\hline
\end{tabular}




\begin{tabular}{|c|c|}
\hline 124 & $\begin{array}{l}\text { VON AUFSCHNAITER, C.; ERDURAN, S.; OSBORNE, J.; SIMON, S. Arguing to Learn and } \\
\text { Learning to Argue: Case Studies of How Students'Argumentation Relates to Their Scientific } \\
\text { Knowledge, } 45,1,2008 .\end{array}$ \\
\hline 125 & $\begin{array}{l}\text { SADLER, T. D.; AMIRSHOKOOHI, A.; KAZEMPOUR, M.; ALLSPAW, K. M. Socioscience } \\
\text { and Ethics in Science Classrooms: Teacher Perspectives and Strategies , 43, 4, } 2006 .\end{array}$ \\
\hline 126 & $\begin{array}{l}\text { SADLER, T. D.; ZEIDLER, D. L. Patterns of Informal Reasoning in the Context of } \\
\text { Socioscientific Decision Making, 42, 1, } 2005 \text {. }\end{array}$ \\
\hline 127 & $\begin{array}{l}\text { SADLER, T. D. Informal Reasoning Regarding Socioscientific Issues: A Critical Review of } \\
\text { Research, 41, 5, } 2004 \text {. }\end{array}$ \\
\hline 128 & $\begin{array}{l}\text { REVELES, J. M.; CORDOVA, R.; KELLY, G. J. Science Literacy and Academic Identity } \\
\text { Formulation, 41, 10, } 2004 .\end{array}$ \\
\hline 129 & $\begin{array}{l}\text { HUGHES, G. Marginalization of Socioscientific Material in Science-Technology-Society } \\
\text { Science Curricula: Some Implications for Gender Inclusivity and Curriculum Reform. 37, 5, } \\
2000 .\end{array}$ \\
\hline 130 & $\begin{array}{l}\text { CROSS, R. T.; PRICE, R. F. Science Teachers' Social Conscience and the Role of Controversial } \\
\text { Is sues in the Teaching of Science, 33, 3, } 1996 .\end{array}$ \\
\hline & 6. Research in Science \& Technological Education \\
\hline 131 & $\begin{array}{l}\text { ROS, R.; GOTT, R. Questioning the Evidence for a Claim in a Socio-Scientific Issue: An } \\
\text { Aspect of Scientific Literacy, } 28,3,2010 .\end{array}$ \\
\hline & 7. Science Education \\
\hline 132 & $\begin{array}{l}\text { RUDSBERG, K.; OHMAN, J.; OSTMAN, L. Analyzing Students' Learning in Classroom } \\
\text { Discussions about Socioscientific Issues, 97, 4, } 2013 .\end{array}$ \\
\hline 133 & $\begin{array}{l}\text { LEE, Y. C.; GRACE, M. Students' Reasoning and Decision Making about a Socioscientific } \\
\text { Issue: A Cross-Context Comparison, 96, 5, } 2012 .\end{array}$ \\
\hline 134 & $\begin{array}{l}\text { VAZQUEZ-BERNAL, B.; MELLADO, V.; JIMENEZ-PEREZ, R.; TABOADA-LENERO, C. } \\
\text { The Process of Change in a Science Teacher's Profes sional Development: A Case Study Based } \\
\text { on the Types of Problems in the Classroom, 96, 2, } 2012 \text {. }\end{array}$ \\
\hline 135 & $\begin{array}{l}\text { NIELSEN, J. A. Science in Discussions: An Analysis of the Use of Science Content in } \\
\text { Socioscientific Discussions, } 96,3,2012 \text {. }\end{array}$ \\
\hline 136 & $\begin{array}{l}\text { LEVINSON, R.; KENT, P.; PRATT, D.; KAPADIA, R.; YOGUI, C. Risk-Based Decision } \\
\text { Making in a Scientific Issue: A Study of Teachers Discussing a Dilemma Through a } \\
\text { Microworld, } 96,2,2012 \text {. }\end{array}$ \\
\hline 137 & $\begin{array}{l}\text { WAN, Z. H.; WONG, S. L.; YUNG, B. H. W. Common Interest, Common Visions? Chinese } \\
\text { Science Teacher Educators' Views About the Values of Teaching Nature of Science to } \\
\text { Prospective Science Teachers, } 95,6,2011 \text {. }\end{array}$ \\
\hline 138 & FEINSTEIN, N. Salvaging science literacy, 95, 1, 2011. \\
\hline 139 & $\begin{array}{l}\text { LIU, S. Y.; LIN, C. S.; TSAI, C. C. College Students'Scientific Epistemological Views and } \\
\text { Thinking Patterns in Socioscientific Decision Making, 95, 3, } 2011 .\end{array}$ \\
\hline
\end{tabular}




\begin{tabular}{|c|c|}
\hline 140 & $\begin{array}{l}\text { EGGERT, S.; BOGEHOLZ, S. Students' Use of Decision-Making Strategies with Regard to } \\
\text { Socioscientific Issues: An Application of the Rasch Partial Credit Model, 94, 2, } 2010 \text {. }\end{array}$ \\
\hline 141 & $\begin{array}{l}\text { JAKOBSSON, A.; MAKITALO, A.; SALJO, R. Conceptions of Knowledge in Research on } \\
\text { Students' Understanding of the Greenhouse Effect: Methodological Positions and Their } \\
\text { Consequences for Representations of Knowing, 93, 6, 2009. }\end{array}$ \\
\hline 142 & $\begin{array}{l}\text { LUNDQVIST, E.; ALMQVIST, J.; OSTMAN, L. Epistemological Norms and Companion } \\
\text { Meanings in Science Classroom Communication, 93, 5, } 2009 .\end{array}$ \\
\hline 143 & $\begin{array}{l}\text { POULIOT, C. Students' Inventory of Social Actors Concerned by the Controversy Surrounding } \\
\text { Cellular Telephones: A Case Study, 92, 3, } 2008 .\end{array}$ \\
\hline 144 & $\begin{array}{l}\text { BENNETT, J.; LUBBEN, F.; HOGARTH, S. Bringing Science to Life: A Synthesis of the } \\
\text { Research Evidence on the Effects of Context-Based and STS Approaches to Science Teaching, } \\
92,3,2008 \text {. }\end{array}$ \\
\hline 145 & $\begin{array}{l}\text { COLUCCI-GRAY, L.; CAMINO, E.; BARBIERO, G.; GRAY, D. From scientific literacy to } \\
\text { sustainability literacy: an ecological framework for education, 90, 2, } 2006 \text {. }\end{array}$ \\
\hline 146 & $\begin{array}{l}\text { KOLSTØ, S. D.; BUNGUM, B.; ARNESEN, E.; ISNES, A.; KRISTENSEN, T.; } \\
\text { MATHIASSEN, K.; MESTAD, I.; QUALE, A.; TONNING, A. S. V.; ULVIK, M. Science } \\
\text { Students' Critical Examination of Scientific Information Related to Socioscientific Issues, 90, } \\
\text { 4, } 2006 .\end{array}$ \\
\hline 147 & $\begin{array}{l}\text { SADLER, T. D.; FOWLER, S. R. A Threshold Model of Content Knowledge Transfer for } \\
\text { Socioscientific Argumentation, 90, 6, } 2006 \text {. }\end{array}$ \\
\hline 148 & $\begin{array}{l}\text { COLUCCI-GRAY, L.; CAMINO, E.; BARBIERO, G.; GRAY, D. From Scientific Literacy to } \\
\text { Sustainability Literacy: An Ecological Framework for Education, 90, 2, } 2006 .\end{array}$ \\
\hline 149 & $\begin{array}{l}\text { SCHERZ, Z; OREN, M. How to Change Students' Images of Science and Technology, 90, 6, } \\
2006 .\end{array}$ \\
\hline 150 & $\begin{array}{l}\text { ZEIDLER, D. L.; SADLER, T. D.; SIMMONS, M. L.; HOWES, E. V. Beyond STS: A } \\
\text { Research-Based Framework for Socioscientific Issues Education, 89, 3, 2005. }\end{array}$ \\
\hline 151 & $\begin{array}{l}\text { SADLER, T. D.; ZEIDLER, D. L. The Significance of Content Knowledge for Informal } \\
\text { Reasoning regarding Socioscientific Issues: Applying Genetics Knowledge to Genetic } \\
\text { Engineering Issues, } 89,1,2005 \text {. }\end{array}$ \\
\hline 152 & $\begin{array}{l}\text { SANDOVAL, W. A. Understanding Students' Practical Epistemologies and Their Influence on } \\
\text { Learning Through Inquiry, 89, 4, } 2005 .\end{array}$ \\
\hline 153 & $\begin{array}{l}\text { SADLER, T. D.; ZEIDLER, D. L. The Morality of Socioscientific Issues: Construal and } \\
\text { Resolution of Genetic Engineering Dilemmas, 88, 1, } 2004 .\end{array}$ \\
\hline 154 & ROTH, W. M.; LEE, S. Science Education as/for Participation in the Community, 88, 2, 2004. \\
\hline 155 & $\begin{array}{l}\text { PEDRETTI, E. G. Perspectives on Learning through Research on Critical Issues-Based Science } \\
\text { Center Exhibitions, 88, } 2004 .\end{array}$ \\
\hline 156 & $\begin{array}{l}\text { DIMOPOULOS, K.; KOULAIDIS, V. Science and Technology Education for Citizenship: The } \\
\text { Potential Role of the Press, 87, 2, } 2003 .\end{array}$ \\
\hline 157 & $\begin{array}{l}\text { DORI, Y. J.; TAL, R. T; TSAUSHU, M. Teaching Biotechnology Through Case Studies Can } \\
\text { We Improve Higher Order Thinking Skills of Nonscience Majors? 87, 6, } 2003 .\end{array}$ \\
\hline
\end{tabular}




\begin{tabular}{|c|c|}
\hline 158 & $\begin{array}{l}\text { ZEIDLER, D. L.; WALKER, K. A.; ACKETT, W. A.; SIMMONS, M.L. Tangled Up in Views: } \\
\text { Beliefs in the Nature of Science and Responses to Socioscientific Dilemmas, 86, 3, } 2002 .\end{array}$ \\
\hline 159 & $\begin{array}{l}\text { KOLST Ø, S. D. Scientific Literacy for Citizenship: Tools for Dealing with the Science } \\
\text { Dimension of Controversial Socioscientific Issues. 85, 3, } 2001 \text {. }\end{array}$ \\
\hline 160 & $\begin{array}{l}\text { DRIVER, R.; NEWTON, P.; OSBORNE, J. Establishing the Norms of Scientific } \\
\text { Argumentation in Classrooms, } 84,3,2000 .\end{array}$ \\
\hline \multicolumn{2}{|r|}{ 8. International Journal of Science and Mathematics Education } \\
\hline 161 & $\begin{array}{l}\text { HOFSTEIN, A.; EILKS, I.; BYBEE, R. Societal Issues and Their Importance for Contemporary } \\
\text { Science Education -A Pedagogical Justification and the State-of-the-Art in Israel, Germany, and } \\
\text { the USA, 9, 6, } 2011 \text {. }\end{array}$ \\
\hline 162 & $\begin{array}{l}\text { LIN, S. S.; MINTZES, J. J. Learning Argumentation Skills through Instruction in } \\
\text { Socioscientific Is sues:The Effect of Ability Level, } 8,6,2010 \text {. }\end{array}$ \\
\hline \multicolumn{2}{|r|}{ 9. Journal of Science Education and Technology } \\
\hline 163 & $\begin{array}{l}\text { CHRISTENSON, N.; RUNDGREN, S. N. C.; HOGLUND, H. O. Using the SEE-SEP Model } \\
\text { to Analyze Upper Secondary Students' Use of Supporting Reasons in Arguing Socioscientific } \\
\text { Is sues, } 21,3,2012 \text {. }\end{array}$ \\
\hline 164 & $\begin{array}{l}\text { VARMA, K.; LINN, M. C. Using Interactive Technology to Support Students' Understanding } \\
\text { of the Greenhouse Effect and Global Warming, 21, 4, } 2012 .\end{array}$ \\
\hline 165 & $\begin{array}{l}\text { HANSSON, L.; REDFORS, A.; ROSBERG, M. Students' Socio-Scientific Reasoning in an } \\
\text { Astrobiological Context during Work with a Digital Learning Environment, 20, 4, } 2011 .\end{array}$ \\
\hline 166 & $\begin{array}{l}\text { CHANG, Y. H.; CHANG, C. Y.; TSENG, Y. H. Trends of Science Education Research: An } \\
\text { Automatic Content Analysis, 19, 4, } 2010 .\end{array}$ \\
\hline 167 & $\begin{array}{l}\text { CONCANNON, J. P.; SIEGEL, M. A.; HALVERSON, K.; FREYERMUTH, S. College } \\
\text { Students' Conceptions of Stem Cells, Stem Cell Research, and Cloning, 19, 2, } 2010 .\end{array}$ \\
\hline \multicolumn{2}{|r|}{ 10. Science Education International } \\
\hline 168 & $\begin{array}{l}\text { ROBERTSHAW, B.; CAMPBELL, T. Constructing arguments: Investigating pre-service } \\
\text { science teachers' argumentation skills in a socio-scientific context, } 24,2,2013 .\end{array}$ \\
\hline 169 & $\begin{array}{l}\text { JUNTUNEN, M.; AKSELA, M. Life-Cycle Analys is and Inquiry-Based Learning in Chemistry } \\
\text { Teaching, 24, 2, } 2013 .\end{array}$ \\
\hline 170 & $\begin{array}{l}\text { QUINN, F.; LYONS, T. High School Students' Perceptions of School Science and Science } \\
\text { Careers: A Critical Look at a Critical Issue. 22, 4, } 2013 .\end{array}$ \\
\hline 171 & $\begin{array}{l}\text { FEIERABEND, T.; EILKS, I. Raising Students' Perception of the Relevance of Science } \\
\text { Teaching and Promoting Communication and Evaluation Capabilities Using Authentic and } \\
\text { Controversial Socio-Scientific Issues in the Framework of Climate Change, 21, 3, } 2010 .\end{array}$ \\
\hline \multicolumn{2}{|r|}{ 11. Studies in Science Education } \\
\hline 172 & $\begin{array}{l}\text { HINGANT, B.; ALBE, V. Nanosciences and Nanotechnologies Learning and Teaching in } \\
\text { Secondary Education: A Review of Literature, 46, 2, } 2010 .\end{array}$ \\
\hline 173 & CHRISTENSEN, C. Risk and School Science Education, 45, 2, 2009. \\
\hline
\end{tabular}




\begin{tabular}{|c|c|}
\hline 174 & $\begin{array}{l}\text { SADLER, T. D. Situated Learning in Science Education: Socio-Scientific Issues as Contexts } \\
\text { for Practice, } 45,1,2009 \text {. }\end{array}$ \\
\hline 175 & $\begin{array}{l}\text { PEDRETTI, E. T. Kuhn Meets T. Rex: Critical Conversations and New Directions in Science } \\
\text { Centres and Science Museums. 37, 1, } 2002 .\end{array}$ \\
\hline \multicolumn{2}{|r|}{ 12. Revista Eetronica de Enseñanza de las Ciencias - REEC } \\
\hline 176 & $\begin{array}{l}\text { BRITO, J. Q. A; SÁ, L. P. Estratégias promotoras da argumentação sobre questões sócio- } \\
\text { científicas com alunos do ensino médio, } 9,3,2010 \text {. }\end{array}$ \\
\hline 177 & $\begin{array}{l}\text { FORGIARINI, M. S.; AULER, D. A abordagem de temas polêmicos na educação de jovens e } \\
\text { adultos: o caso do "florestamento" no Rio Grande do Sul, 8, 2, } 2009 .\end{array}$ \\
\hline 178 & $\begin{array}{l}\text { REIS, P.; GALVÃO, C. Os professores de Ciências Naturais e a discussão de controvérsias } \\
\text { sociocientíficas: dois casos distintos, } 7,3,2008 \text {. }\end{array}$ \\
\hline 179 & $\begin{array}{l}\text { REIS, P.; GALVÃO, C. O diagnóstico de concepções sobre os cientistas através da análise e } \\
\text { discussão de histórias de ficção científica redigidas pelos alunos, } 5,2,2006 \text {. }\end{array}$ \\
\hline \multicolumn{2}{|r|}{ 13. Ciência \& Ensino } \\
\hline 180 & $\begin{array}{l}\text { BERNARDO, J. R. R.; VIANNA, D. M.; FONTOURA, H. A. Produção e consumo da energia } \\
\text { elétrica: a construção de uma proposta baseada no enfoque ciência-tecnologia-sociedade- } \\
\text { ambiente (CTSA), 1, NE, } 2007 \text {. }\end{array}$ \\
\hline 181 & $\begin{array}{l}\text { ZUIN, V. G.; FREITAS, D. A utilização de temas controversos: umestudo de caso na formação } \\
\text { de licenciandos numa abordagem CTSA, 1, 2, } 2007 .\end{array}$ \\
\hline 182 & $\begin{array}{l}\text { SILVA, L. F.; CARVALHO, L. M. A temática ambiental e o processo educativo: o ensino de } \\
\text { física a partir de temas controversos, } 1, \mathrm{NE}, 2007 \text {. }\end{array}$ \\
\hline 183 & $\begin{array}{l}\text { NAVAS, A. M.; CONTIER, D.; MARANDINO, M. Controvérsia científica, comunicação } \\
\text { pública da ciência e museus no bojo do movimento CTS, 1, NE, } 2007 \text {. }\end{array}$ \\
\hline 184 & $\begin{array}{l}\text { VIEIRA, K. R. C. F.; BAZZO, W. A. Discussões acerca do aquecimento global: uma proposta } \\
\text { CTS para abordar esse tema controverso em sala de aula, 1, NE, } 2007 .\end{array}$ \\
\hline 185 & $\begin{array}{l}\text { RAMOS, M. B.; SILVA, H. C. Para pensar as controvérsias científicas em aulas de ciências, 1, } \\
\text { NE, } 2007 .\end{array}$ \\
\hline \multicolumn{2}{|r|}{ 14. Ciência \& Educação } \\
\hline 186 & $\begin{array}{l}\text { SILVA, P. F.; MYRIAN K. Bioética e ensino de ciências: o tratamento de temas controversos } \\
\text { - dificuldades apresentadas por futuros professores de ciências e biologia, 19, 2, } 2013 \text {. }\end{array}$ \\
\hline 187 & $\begin{array}{l}\text { MUNDIM, J. V.; SANTOS, W. L. P. O ensino de ciências no ensino fundamental por meio de } \\
\text { temas sociocientíficos: análise de uma prática pedagógica com vista à superação do ensino } \\
\text { disciplinar, } 18,4,2012 \text {. }\end{array}$ \\
\hline 188 & $\begin{array}{l}\text { GALVÃO, C.; REIS, P.; FREIRE, S. A discussão de controvérsias sociocientíficas na formação } \\
\text { de professores, 17, 3, } 2011 .\end{array}$ \\
\hline 189 & $\begin{array}{l}\text { GUIMARÃES, M. A.; CARVALHO, W. L. P.; OLIVEIRA, M. S. Raciocínio moral na tomada } \\
\text { de decisões em relação a questões sociocientíficas: o exemplo do melhoramento genético } \\
\text { humano, } 16,2,2010 \text {. }\end{array}$ \\
\hline
\end{tabular}




\begin{tabular}{|c|c|}
\hline \multicolumn{2}{|r|}{ 15. Ensaio: Pesquisa em Educação em Ciências } \\
\hline 190 & $\begin{array}{l}\text { SANTOS, M. S.; AMARAL, C. L. C.; MACIEL, M. D. Tema sociocientífico "cachaça" em } \\
\text { aulas práticas de química na educação profissional: uma abordagem CTS, 14, 1, } 2012 \text {. }\end{array}$ \\
\hline 191 & $\begin{array}{l}\text { BARBOSA, L. G. D.; LIMA, M. E. C. C.; MACHADO, A. H. Controvérsias sobre o } \\
\text { aquecimento global: circulação de vozes e sentidos produzidos em sala de aula, 14, 1, } 2012 \text {. }\end{array}$ \\
\hline 192 & $\begin{array}{l}\text { PEREZ, D. M.; REBECHI, D.; AZEVEDO, K. L.; SCHREINER, P. G.; MATTIA, R. C.; } \\
\text { SLOWIK, R. e OLIVEIRA, O. B. Temas polêmicos e a argumentação de estudantes do curso de } \\
\text { ciências biológicas, 13,2, 2011. }\end{array}$ \\
\hline 193 & $\begin{array}{l}\text { ALVES, S. B. F.; CALDEIRA, A. M. A. Biologia e ética: um estudo sobre a compreensão e } \\
\text { atitudes de alunos do ensino médio frente ao tema genoma/DNA, 7, 1, } 2005 \text {. }\end{array}$ \\
\hline \multicolumn{2}{|r|}{ 16. Investigações em Ensino de Ciências } \\
\hline 194 & MENDES, M. R. M.; SANTOS, W. L. P. Argumentação em discussões sociocientíficas, 18, 3, 2013. \\
\hline 195 & $\begin{array}{l}\text { SANTOS, W. L. P.; MORTIMER, E. F. Abordagem de aspectos sociocientíficos em aulas de } \\
\text { ciências: possibilidades de limitações, 14, 2, } 2009 .\end{array}$ \\
\hline 196 & $\begin{array}{l}\text { SILVA, L. F.; CARVALHO, L. M. Professores de física em formação inicial: o ensino de física, } \\
\text { a abordagem CTS e os temas controversos, 14, 1, } 2009 \text {. }\end{array}$ \\
\hline 197 & $\begin{array}{l}\text { RAZERA, J. C. C.; NARDI, R. Ética no ensino de ciências: responsabilidades e compromissos } \\
\text { com a evolução moral da criança nas discussões de assuntos controvertidos, 11, 1, } 2006 .\end{array}$ \\
\hline 198 & $\begin{array}{l}\text { REIS, P.; GALVÃO, C. Controvérsias sócio-científicas e prática pedagógica de jovens } \\
\text { professores, } 10,2,2005 \text {. }\end{array}$ \\
\hline
\end{tabular}





\section{APÊNDICE B - TERMO DE CONSENTIMENTO LIVRE E ESCLARECIDO PARA ESTUDANTES}

Caro estudante,

Vimos the convidar a participar da pesquisa "A moral em questões sociocientíficas no ensino de Biologia", cujo objetivo é o desenvolvimento de uma pesquisa-ação com professores de Biologia do ensino médio em escolas públicas do Distrito Federal na promoção de debates de questões sociocientíficas controvérsias envolvendo aspectos morais e éticos com o objetivo central de identificar e analisar crenças e valores morais no discurso de estudantes de ensino médio, visando compreender o papel dessas discussões no raciocínio moral dos estudantes.

Asseguramos que seu nome será substituído por pseudônimo e não haverá menção de sua identidade em nenhum documento derivado desta pesquisa. Os dados gerados poderão ser usados para possíveis publicações em revistas científicas especializadas e apresentações em conferências profissionais e acadêmicas.

Se em qualquer momento você decidir retirar-se da pesquisa, poderá fazê-lo sem qualquer inconveniente e, assim sendo, haverá a pronta remoção dos dados coletados sobre sua participação nos resultados finais do estudo.

Se você concordar com a participação neste estudo, por favor, assine e retorne o Termo de Consentimento Livre e Esclarecido a seguir. Do contrário, por favor, devolva o referido documento em branco.

Colocamo-nos à sua inteira disposição para elucidar e responder a quaisquer perguntas. Agradeço antecipadamente a atenção dispensada.

Atenciosamente,

Profa. Shirley Margareth Buffon da Silva

Professora da de Biologia da Secretaria de Estado de Educação do DF e doutoranda do Programa de Pós-Graduação em Educação, Faculdade de Educação, UnB.

\section{TERMO DE CONSENTIMENTO LIVRE E ESCLARECIDO}

Eu, abaixo identificado (a), concordo em participar da Pesquisa intitulada "A moral em questões sociocientíficas no ensino de Biologia". Estou ciente que, de maneira geral, a pesquisa objetiva o desenvolvimento de uma pesquisa-ação com professores de Biologia do ensino médio em escolas públicas do Distrito Federal na promoção de debates de questões 
sociocientíficas controvérsias envolvendo aspectos morais e éticos com o objetivo central de identificar e analisar crenças e valores morais no discurso de estudantes de ensino médio, visando compreender o papel dessas discussões no desenvolvimento moral dos estudantes.

Estou também ciente de que a metodologia utilizada é de caráter qualitativo, privilegiando a construção de dados a partir da análise das transcrições de respostas dadas a entrevistas e vídeo gravações de aulas realizadas com os sujeitos da pesquisa proposta: estudantes e professores do curso.

Participação no estudo: Estou ciente de que o procedimento de pesquisa se constitui em coleta de dados sob a forma de entrevistas e vídeo gravações de aulas. Também estou ciente de que meu nome não será mencionado em nenhum documento derivado deste estudo, sendo substituído por um pseudônimo. Estou ciente de que os resultados desta pesquisa servirão para apresentação de trabalhos que poderão ser publicados em revista científica especializada, e, utilizados para apresentações em conferências profissionais e acadêmicas, com o intuito de ampliar e aprofundar o debate educacional, envolvendo universidades, escolas, governos e sociedade, em geral.

Não participação no estudo: Estou ciente de que tenho o direito de fazer qualquer questionamento ou expressar qualquer comentário referente à minha participação neste estudo. Também estou ciente de que eu tenho o direito de desistir de participar do mesmo a qualquer momento e que nenhuma pergunta me será feita e não sofrerei nenhum inconveniente por isto.

Brasilia, 13 de agosto de 2014.

Assinatura

Nome completo (letra de impressão, CAIXA ALTA) 


\section{APÊNDICE C - QSC SOBRE MILHO TRANSGÊNICO}

\section{A. Milho Bt}

O milho transgênico com atividade inseticida representa uma alternativa de diminuir os danos causados por insetos-praga. Esse transgênico é popularmente conhecido como milho Bt, pois na sua elaboração foi incorporado um gene de uma bactéria de solo denominada Bacillus thuringiensis $(\mathrm{Bt})$, que produz uma toxina com ação inseticida específica contra larvas de alguns insetos. Desde 2005 esse milho transgênico foi introduzido no Brasil.

A partir dos dados apresentados em sala de aula responda a seguinte questão:

1. Você concorda ou discorda com o uso do milho Bt? Explique sua resposta.

\section{B. Salmão transgênico}

O salmão geneticamente modificado foi criado pela empresa AquaBounty para crescer mais rápido. Seu tamanho máximo é o mesmo da espécie selvagem (sem modificação genética), mas ele chega lá em apenas 18 meses — metade do tempo normal. Para fazer esse salmão transgênico, os cientistas inseriram dois genes: um do salmão do Pacífico, responsável pela expressão do hormônio do crescimento, e outro de uma enguia, que acelera a ação do primeiro. Como esses genes alteram a produção de hormônios, o novo salmão cresce tão rapidamente que pode chegar ao tamanho para ser comercializado na metade do tempo. Segundo a empresa, o salmão transgênico economiza tempo, espaço e recursos naturais, diminuindo a pressão na pesca da espécie nativa. O produto, entretanto, enfrenta resistência de organizações ambientais. Os ativistas dizem que a alta quantidade de hormônios encontrada no peixe pode ser prejudicial à saúde.

Quais são os prós e contras do salmão transgênico? Confira abaixo o gráfico que explica as razões da polêmica. 


\section{CONHECA OSALMÃOTRANSGÊNICO}

O governo dos EUA pode aprovar um salmão com os genes alterados para crescer mais rapidamente. Se aprovado, será o primeiro tipo de carne geneticamente modificada no mercado
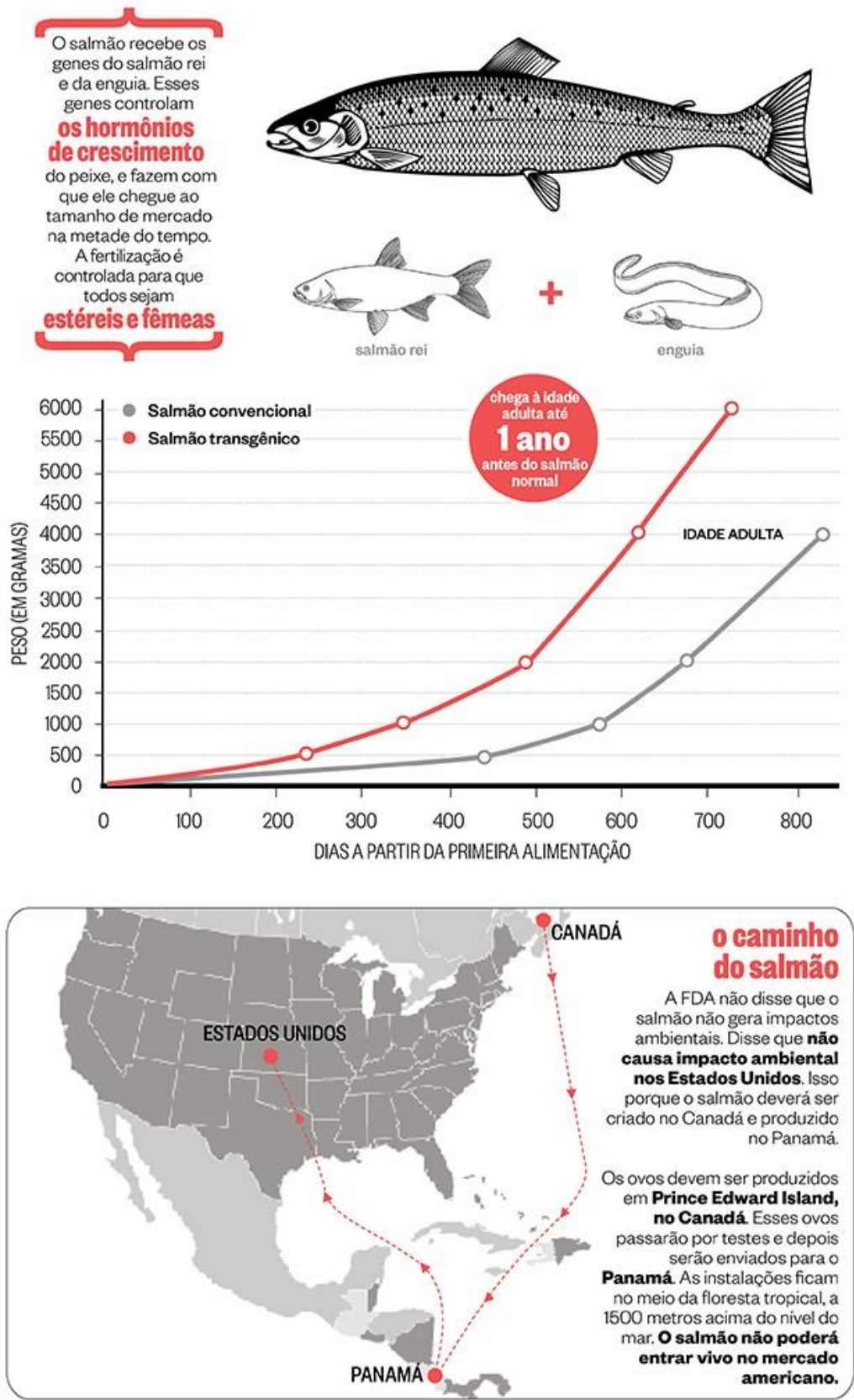

\section{PRÓS}

Segundo a empresa, o salmão

modificado tem as mesmas qualidades

nutricionais queosalmãocomum

Como leva menos tempo para crescer,

opeixe exige menor quantidade de

recursos naturaise espaço para ser criado

\section{GONTRAS}

Ativistas dizem que o peixe tem $40 \%$ mais hormônio, o que pode aumentar o risco de doenças

Se escapar para o ambiente, o peixe pode conseguir se reproduzir e levar a espécie natural à extinção

Fonte: Revista Época, 2013

1. A partir das informações apresentadas você compraria um salmão geneticamente modificado? Explique sua resposta. 


\section{APÊNDICE D - QSC SOBRE CLONAGEM REPRODUTIVA}

\section{Caso sobre clonagem reprodutiva}

Os pais de uma criança com um tipo de leucemia extremamente grave são informados que ela só poderá ser salva com um transplante de medula. Visto não existir qualquer doador compatível, os pais decidem pela obtenção de um clone humano a partir de células da criança doente. Se esta técnica for bem-sucedida, a nova criança será o doador ideal para um transplante de medula que poderá ser efetuado sem risco ou desconforto significativos. No final os pais poderão ficar com duas crianças saudáveis, duas gêmeas idênticas com idades diferentes, que amarão muito. (REIS, 2003).

Observação: considerar que a leucemia não é hereditária, dessa forma não será transmitida para o clone.

Em sua opinião, qual deveria sera decisão do casal em questão? Justifique. 



\section{APÊNDICE E- QSC SOBRE TERAPIA GÊNICA}

\section{Atenção! Leia o texto atentamente para responder as próximas questões. Terapia Gênica}

Esta tecnologia recente envolve a retirada de células do doente, a sua modificação por engenharia genética e sua posterior reintrodução no mesmo indivíduo. A modificação destas células resulta da introdução de um gene ativo que antes não possuíam. Até agora, a terapia gênica é realizada apenas em células somáticas (todas as células do organismo com exceção dos gametas); no entanto, prevê-se uma futura aplicação em células da linhagem germinal (células sexuais).

Atualmente, doenças como a hemofilia $\mathrm{B}$, a fibrose cística, a leucemia, a imunodeficiência severa combinada e alguns tipos de câncer começam a ser tratadas por terapia gênica. Apesar dos benefícios curativos e preventivos da terapia gênica somática, reforça-se a importância da avaliação de eventuais riscos como, por exemplo, a inserção do gene em células não alvo, resposta inflamatória e falta de controle da ativação (funcionamento) do gene de interesse. Em pessoas saudáveis, é provável que tais problemas sejam ainda mais importantes, já que poderia haver um excesso do produto do gene transferido.

Devido às perspectivas de tratamento de doenças para as quais não existe melhores alternativas a terapia gênica não encontra dificuldade para ser considerada legítima. Entretanto, essa técnica pode ser utilizada não apenas com finalidade terapêutica, mas também com objetivo de melhoramento ou aprimoramento genético que se baseia apenas na modificação e no aperfeiçoamento de características normais. Por exemplo, adição de genes que possam melhorar o desempenho de atletas de alto rendimento.

$\mathrm{O}$ uso da terapia gênica com objetivo de melhoramento ou aprimoramento de características normais suscita questões de ordem moral e ética. Recentemente, o potencial para uso indevido da terapia gênica entre atletas tem despertado a atenção de cientistas e de órgãos reguladores de esporte. A transferência de genes que poderiam melhorar o desempenho esportivo por atletas saudáveis foi proibida em 2003 pela Agência Mundial Antidoping (WADA/AMA) e foi denominada doping genético.

\section{Caso sobre o albinismo}

Imagine que $\mathrm{X}$ regressou da escola com os óculos quebrados e um olho roxo.

$\mathrm{X}$, conta a sua mãe: no olho.

Mãe meu colega me chamou de anormal por causa da minha cor e me deu um murro

X é albino, ou seja, não tem pigmentos (melanina) devido a uma alteração genética que causa a ausência da enzima tirosinase que é responsável pela conversão da tirosina em melanina. Logo, a sua pele é bastante clara, o seu cabelo é branco e os seus olhos são cor-derosa, por isso deve evitar a exposição ao sol, pois tem grande possibilidade de sofrer queimaduras solares e de desenvolver câncer de pele. Tem que usar óculos, porque não vê bem e a luz intensa prejudica os olhos.

_ Não aguento mais passar por isso. Meus colegas zombam de mim por que sou albino... As pessoas ficam me olhando na rua, sou feio e cheio de limitações, não posso pegar sol, não enxergo direito. Se tivesse alguma forma de mudar isso... algum tratamento... qualquer coisa para mudar essa situação!

A mãe de X que o ama sempre que os colegas do filho o maltratam, pensa que gostaria que o filho não fosse tão diferente. 
Ah meu Deus! Como eu gostaria que meu filho fosse como os outros! Ele sofre tanto por ser albino, as pessoas tem muito preconceito! É um menino tão bom e inteligente, um filho maravilhoso!

Suponha que alguns investigadores descobriram um processo de corrigir o problema de X chamado terapia gênica, que se caracteriza pela inserção do gene responsável pela produção da enzima tirosinase, que controla a produção de melanina. Com este tratamento tanto a pele como o cabelo e os olhos de $\mathrm{X}$ passariam a produzir pigmentação e ele não precisaria mais passar por tanto preconceito e constrangimento. Adaptado de (REIS, 2003).

1. Considera que $X$ deveria ser submetido a este tratamento genético? Será o albinismo um problema médico que necessita de correção?

2. Deverá a sociedade gastar os seus recursos na tentativa de descobrir um tratamento para o albinismo ou a ensinar as crianças e os adultos a aceitarem os cidadãos com "diferenças"?

\section{Caso sobre o doping genético}

Imagine que $\mathrm{X}$, um atleta de alta performance, ganhador de vários prêmios em competições e medalha de ouro nas Olimpíadas de 2012, apesar dos treinamentos incessantes, começou a ter uma queda no desempenho em algumas provas. Com a aproximação de novas competições e das Olimpíadas de 2016, X expõe sua preocupação a seu primo, Y:

Y, estou preocupado, pois tenho sofrido pressão por parte do meu treinador. Quero dar o melhor de mim nos treinos e nas competições e ser motivo de orgulho para minha família e para meu país, mas está difícil... sinto que estou já no limite do meu corpo, mas acho que não é suficiente...

Primo, tenho ouvido falar que tem muita gente fazendo um procedimento para melhora do desempenho... parece que se chama doping genético... você já ouviu falar?

_ Não sei... mas não haveria problemas nisso? Parece estranho... Eu não corro risco de pego nos testes antidoping?

Pesquisando sobre $\mathrm{o}$ assunto, $\mathrm{X}$ chegou ao conhecimento da terapia gênica e do doping genético, que se caracteriza pela transferência de genes extras que poderiam melhorar o desempenho esportivo de atletas saudáveis que, por sua vez, é de difícil detecção pelos testes existentes. Esse fato despertou o seu interesse. Suponha que você é amigo (a) de X. O que você faria para ajudá-lo a decidir? Elaboração da autora

Que escolha você acha que $\mathrm{X}$ de ve realizar? Justifique. 


\section{APÊNDICE F - QUESTÕES PARA NORTEAR A DISCUSSÃO SOBRE MILHO TRANSGÊNICO}

Questões para a discussão

1. Temos o direito de interferir na estrutura dos organismos (vegetais, animais e bactérias)?

2. Organismos geneticamente modificados podem aumentar a dependência dos países subdesenvolvidos às novas tecnologias?

3. É possível haver um proprietário de genes e outras parcelas de DNA (ou proteínas ou RNA)? Se sim, quem tem o direito?

4. Como deve acontecer a participação das empresas privadas no patenteamento das biotecnologias genéticas, gênicas e genômicas?

5. Há implicações quanto à responsabilidade moral e legal dos agentes nas descobertas genéticas? 



\section{APÊNDICE G - QUESTÕES PARA NORTEAR A DISCUSSÃO SOBRE CLONAGEM REPRODUTIVA}

Questões para a discussão

1. A pesquisa com células-tronco embrionárias deve ser permitida, embora signifique a morte de embriões?

2. E a clonagem terapêutica?

3. Genes são responsáveis pelo comportamento das pessoas?

4. Há implicações quanto à responsabilidade moral e legal dos agentes nas descobertas genéticas?

5. Quanto os pais devem poder decidir na reprodução assistida?

6. Como isso pode afetar o futuro da criança?

7. A pesquisa com células-tronco embrionárias deve ser permitida, embora signifique a morte de embriões?

8. A seleção genética de embriões deve ser permitida? 